\title{
Constructing worlds with words : science and international language in the early twentieth century
}

Citation for published version (APA):

de Kloe, F. (2014). Constructing worlds with words : science and international language in the early twentieth century. [Doctoral Thesis, Maastricht University]. https://doi.org/10.26481/dis.20140618fk

Document status and date:

Published: 01/01/2014

DOI:

10.26481/dis.20140618fk

Document Version:

Publisher's PDF, also known as Version of record

\section{Please check the document version of this publication:}

- A submitted manuscript is the version of the article upon submission and before peer-review. There can be important differences between the submitted version and the official published version of record.

People interested in the research are advised to contact the author for the final version of the publication, or visit the DOI to the publisher's website.

- The final author version and the galley proof are versions of the publication after peer review.

- The final published version features the final layout of the paper including the volume, issue and page numbers.

Link to publication

\footnotetext{
General rights rights.

- You may freely distribute the URL identifying the publication in the public portal. please follow below link for the End User Agreement:

www.umlib.nl/taverne-license

Take down policy

If you believe that this document breaches copyright please contact us at:

repository@maastrichtuniversity.nl

providing details and we will investigate your claim.
}

Copyright and moral rights for the publications made accessible in the public portal are retained by the authors and/or other copyright owners and it is a condition of accessing publications that users recognise and abide by the legal requirements associated with these

- Users may download and print one copy of any publication from the public portal for the purpose of private study or research.

- You may not further distribute the material or use it for any profit-making activity or commercial gain

If the publication is distributed under the terms of Article $25 \mathrm{fa}$ of the Dutch Copyright Act, indicated by the "Taverne" license above, 


\title{
CONSTRUCTING WORLDS WITH WORDS
}

\author{
Science and international language \\ in the early twentieth century
}

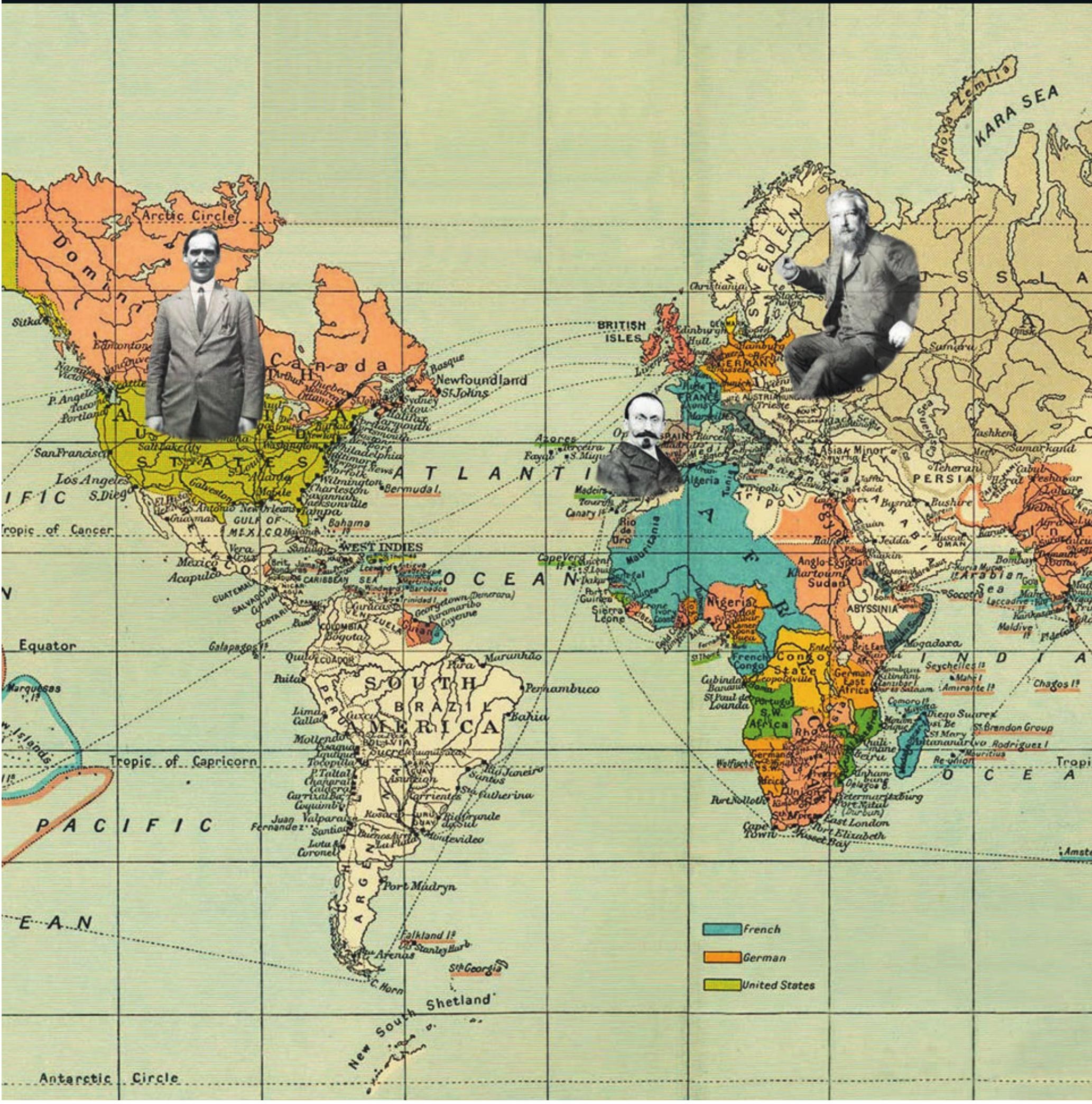


The printing of this dissertation has been financially supported by the Netherlands Graduate Research School of Science, Technology and Modern Culture (WTMC). 


\title{
Constructing worlds with words \\ Science and international language in the early twentieth century
}

\author{
Proefschrift
}

ter verkrijging van de graad van doctor aan de Universiteit Maastricht
op gezag van Rector Magnificus, Prof. dr. L.L.G. Soete,
volgens het besluit van het College van Decanen
in het openbaar te verdedigen op woensdag 18 juni 2014 om 16.00 uur

door

Fabian de Kloe 


\section{Promotor}

Prof. dr. ir. W.E. Bijker

\section{Co-promotores}

Dr. G.J. Somsen

Dr. N. Randeraad

\section{Beoordelingscommissie}

Prof. dr. K.K. Patel (voorzitter)

Dr. R. de Bont

Prof. dr. E. Homburg

Prof. dr. F.H. van Lunteren, VU University of Amsterdam

Prof. dr. J. Paulmann, director of the Leibniz Institute of European History and Professor of modern history at the University of Mainz 


\section{TABLE OF CONTENTS}

\section{CHAPTER 1}

Exploring internationalism

1.1 The sciences were never at war?

1.2 Local to the core

1.3 A world unified through science

1.4 Framing the case study

\section{CHAPTER 2}

Beyond Babel: Louis Couturat's creation and promotion of Ido 36

2.1 Couturat's dream 38

2.2 The return of Babel $\quad 42$

2.3 Building a scientific language $\quad 44$

2.4 Early-twentieth-century Babel as myth $\quad 47$

2.5 Logic as objectivity machine $\quad 56$

2.6 Beyond national chauvinism $\quad 59$

2.7 Leibniz as scientific internationalist avant la lettre $\quad 61$

2.8 For the glory of the French republic 64

\section{CHAPTER 3}

Towards a German organization of the world:

Wilhelm Ostwald and international language 66

3.1 Ostwald's promotion of Ido part I: a Franco-German alliance 69

3.2 Part II: the "Brücke" and the Monistic Alliance 77

3.3 From the periphery to the center 86

3.4 Ostwald's energetics $\quad 89$

3.5 Ostwald's appropriation of Comte 93

3.6 A German organization of the world 96

3.7 World War I: Ido abandoned, internationalism continued 100 


\section{CHAPTER 4}

A socially responsible engineer: Frederick Cottrell's pursuit of a scientific international language

4.1 From prewar to postwar international language politics

4.2 Cottrell becomes international language proponent

4.3 A shrinking world

4.4 Science as social experiment

4.5 The rise of the socially responsible engineer

4.6 IL: an instrument of American expansionism

4.7 The socially responsible engineer and American philanthropy join forces

4.8 Interlingua: an IL by linguists for science

\section{CHAPTER 5}

Constructing worlds with words: on the myth and function of scientific internationalism

5.1 The diversity of scientific internationalism $\quad 140$

5.2 The narrowness of scientific internationalism $\quad 144$

5.3 Fostering nationalism through language $\quad 148$

5.4 Fostering scientific internationalism through language $\quad 155$

5.5 Real imaginations 158

REFERENCES 162

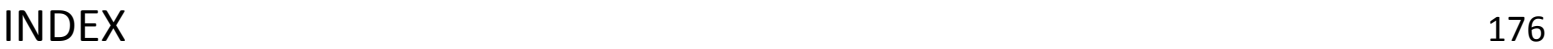

SAMENVATTING 180

CURRICULUM VITAE 194 


\section{ACKNOWLEDGEMENTS}

Many people, both my professional colleagues and friends, have helped in bringing this book to fruition. Occasionally I was fortunate enough to see the distinction between colleague and friend dissolve in the process. More than once, this has helped to infuse me with inspiration.

In this respect, I'm especially grateful to Geert Somsen. He has not only been instrumental in pushing me to further develop the initial research idea for this project. His insights, critical acumen, and above all, his engagement, have been a crucial engine behind the realization of this dissertation. I'm also greatly indebted to Wiebe Bijker and Nico Randeraad for keeping a clear oversight on both the general arguments and the overall readability of the manuscript.

I want to mention fellow graduate students Joeri Bruyninckx, Verena Anker, Matthijs Kouw, and Leen Roels, with whom I had countless valuable conversations on the experience of writing a dissertation. These interactions minimized the sense of isolation that is inevitable when writing a dissertation. I also want to thank Joeri and Verena for their input on an earlier version of chapter 2 . Other colleagues who have provided valuable comments on this chapter were Ilse Raaijmakers and Constance Sommerey. A rewritten version was published in an edited volume. I'm indebted to the editor, Boyd Rayward, for his detailed and helpful suggestions for improvement.

Many of the ideas and arguments in this dissertation were conceived during research trips and workshops. My stay at the Harvard History of Science Department in the Fall of 2011 was especially formative in this regard. I want to thank those who made this unforgettable experience possible. The Netherlands Graduate Research School for Science, Technology and Modern Culture (WTMC) provided another inspirational platform in the form of workshops and summer schools. Special thanks to its academic coordinators: Sally Wyatt, Willem Halffman, Teun Zuiderent-Jerak.

The research behind this dissertation was also facilitated by the professionalism, helpfulness and enthusiasm of several archivists. Two in particular need to be mentioned. Firstly, I want to thank Claude Gacond, archivist and founder of the Centre de documentation et d'étude sur la langue international (CDELI) in La Chaux-de-Fonds, 
Switzerland. Besides being thankful for his eagerness to assist in unearthing relevant source material, I'm especially grateful for his riveting stories pertaining to the history of international languages. I also want to thank archivist Dena McDuffie for her warm reception and guidance at the Research Corporation for Science Advancement (RCSA) in Tucson, Arizona. As probably the single most knowledgeable person on Frederick Cottrell's life and times, Dena enthusiastically navigated me through the source material at hand.

Finally, no amount of words can express my gratitude to my close friends, my parents, and especially the one that stands closest to me, for giving support and showing the patience of a Tibetan monk. 


\section{CHAPTER 1}

\section{Exploring internationalism}

"The International Space Station is an orbital turkey. No important science has come out of $i{ }^{\prime \prime} .{ }^{1}$ This is what physicist and Nobel Laureate Steven Weinberg once said about the ISS, a joint project between the American, European, Russian, Japanese and Canadian space agencies. To Weinberg, the space station is like a stuffed dead bird, uselessly circling the earth, despite the roughly 100 billion Euros that the participating nations have invested in it since 2001.

Not everybody agrees with Weinberg's verdict. According to a Dutch spokesperson of the project it is a mistake to judge it only in terms of its scientific output: "the International Space Station (ISS) is not primarily meant for science. It is about international cooperation". ${ }^{2}$ NASA also articulates the importance of the project in terms of international collaboration. Its website says:

Did you know that people have been living and working in space around the clock, every single day, for more than ten years? During the past decade, 15

\footnotetext{
${ }^{1}$ Weinberg, Steven (2007). Nobel Laureate Disses NASA's Manned Spaceflight. By Ker Than. Retrieved from the Worldwide Web on August 30th, 2012:

http://www.space.com/4357-nobel-laureate-disses-nasa-manned-spaceflight.html

2 “(...) het International Space Station (ISS) is er ook helemaal niet primair voor de wetenschap. Het ging om internationale samenwerking." Knip, Karel (2012). 'De hemel heeft een muis gebaard,' NRC March 30.
} 
nations have come together, setting aside boundaries and differences, to design, assemble, occupy, and conduct research inside and outside of the largest and longest inhabited object to ever orbit the Earth - the International Space Station. ${ }^{3}$

On a clear night the ISS can be seen with the naked eye as a speck of bright light in the heavens. If this is an orbital turkey, it is a sacred one. The image of scientists from different nations conducting experiments above the earth is powerful and familiar. Scientists have a strong reputation as exemplary internationalists that can be traced back to the ideal of the Republic of Letters, the illustrious community of scholars and literary figures of the seventeenth and eighteenth century. Its learned members are also said to have 'orbited' above national differences through their circulation of letters for the sake of furthering man's knowledge.

It is often claimed that scientists communicate in a language that they understand irrespective of their nationhood. Those who master and apply the scientific method are predisposed to cooperate in a peaceful and orderly manner, transcending national rivalries as they work together to expand our knowledge of the world. Endowed with such a glorious reputation, scientific collaboration is seen as pioneering and exemplifying the globalization of the world.

The ISS is one of the latest examples in a long tradition of what many view as the most pristine form of internationalism. Internationalists generally advocate economic and political cooperation among nations for the benefit of all. This agenda has been a dominant feature of the world's political landscape since at least World War II. Despite its political popularity, few have attempted to understand internationalism from a historical perspective.

According to Akira Iriye, Harvard professor in the history of international relations, "[s]cholars have written volumes on the history of the contemporary world, or more specifically of modern international relations, but few such volumes seem to contain more than a passing reference, if at all, to international organizations" ${ }^{4}$ In his own work, e.g. his seminal Global Community (2004), Iriye focuses on six types of such organizations - for humanitarian relief, cultural exchange, peace and disarmament, developmental assistance, human rights, and environmentalism - in order to point out that "underneath the geopolitical realities defined by sovereign states, the [twentieth] century witnessed a steady growth of another reality - the global (and globalizing) activities by international organizations". 5

\footnotetext{
3 'Introduction,' NASA - International Space Station. Retrieved from the Worldwide Web on August 30th, 2012: http://www.nasa.gov/mission_pages/station/main/index.html

${ }^{4}$ Iriye, Akira (2002). Global Community: The Role of International Organizations in the Making of the Contemporary World. Berkeley, Los Angeles: University of California Press.

${ }^{5}$ Ibid. p. 202.
} 
Iriye claims that his project is meant to compensate what he calls a "puzzling" contrast between the apparent topological hiatus on the agenda of contemporary historians on the one hand, and on the other an explosion of international studies within the field of political sciences since the 1970s. Political science continues to produce important insights and critical perspectives on international organizations. But most of this work tends to focus on the recent present and the future with a keen eye on contributing to policy-related improvements.

Some point out that a historical hiatus in internationalism studies also exists in the field of European studies. According to historian Mark Mazower the study of Europe has left an important gap, which only recently has begun to be filled by Perry Anderson:

Europe appears to be an "impossible object," constantly slipping among three quite distinct literatures. There are histories of the postwar continent, mostly written in the shadow of the cold war and paying little attention to the European Union; there is a vast outpouring of works, popular and scholarly, focusing not on Europe per se but on this or that European country. (...) Finally, there is what we might call professional EUrology: a series of interventions, chiefly by legal scholars and political scientists, on the technicalities of the integration process and its institutions. Given the amnesiac quality of much of this last in particular, Anderson's ability to move fluently among the three literatures, and above all to evaluate the EU as an ideology, is necessary and timely. ${ }^{6}$

Anderson's answer to this historical hiatus in European studies offers a sobering portrait of a project that is usually viewed as a radiant moral and political example to the world. He presents a picture of the European project as a heterogeneous narrative, made up of a plethora of different programs pursued by a multitude of actors with differing ideas on Europe and on who is supposed to benefit from it. His point is that a European consciousness might well exist, but what it means for those who believed in it is variable.

In a different study Anderson shows that this also counts for the broader ideology of internationalism. ${ }^{7}$ In it Anderson traces the idea of internationalism since the eighteenth century into the twentieth century. He concludes that what it meant for those who articulated it has undergone several metamorphoses against the backdrop of successive

\footnotetext{
${ }^{6}$ Mazower, Mark (2010). 'Anderson's Amphibologies: On Perry Anderson,' The Nation April 26. Retrieved from the Worldwide Web on August 27 ${ }^{\text {th }}, 2012$ : http://www.thenation.com/article/andersonsamphibologies-perry-anderson

${ }^{7}$ Anderson, Perry. (2002) 'Internationalism: A Breviary,' New Left Review (14): pp. 5-25. Retrieved from the Worldwide Web on October $10^{\text {th }}, 2011$ : http://newleftreview.org/II/14/perry-anderson-internationalism-abreviary
} 
phases of nationalism. The insight that internationalism as an ideology takes on differing conceptual meanings in different periods might not be surprising, but such a historically grounded notion of internationalism is still far from conventional. In fact, Anderson himself points out once more that in contrast to nationalism, its supposed anti-thesis, internationalism remains unchartered territory for historians:

(...) while nationalism is of all political phenomena the most value contested - judgments of its record standardly varying across a 180-degree span, from admiration to anathema - no such schizophrenia of connotation affects internationalism: its implication is virtually always positive. But the price of approval is indeterminacy. If no-one doubts the fact of nationalism, but view agree as to its worth, at the entry of the millennium, the status of internationalism would appear to be more or less the reverse. It is claimed on all sides as a value, but who can identify it without challenge as a force? ${ }^{8}$

Iriye's Global Community might well offer a rich overview of international organizations. But his conception of internationalism nonetheless suffers from the very indeterminacy Anderson warns us about. The many international organizations and initiatives described in it are mobilized to argue for the reality and desirability of what he calls "the building of transnational networks that are based upon global consciousness, the idea that there is a wider world over and above separate states and national societies (...)". ${ }^{9}$ By claiming this, Iriye takes for granted that the countless actors involved in the promotion of internationalism share the same program as he does. This assumption leads to sweeping statements such as "international organizations (...) represented the consciousness of the world when individual states were destroying the peace and seeking to divide the globe into self-contained empires," and "global consciousness was kept alive by the heroic efforts of nonstate actors that preserved the vision of one world". ${ }^{10}$ Internationalism has become the latest incarnate of the Hegelian spirit that pushes society to its final stage, namely a global community.

Such a perspective reveals little about internationalism other than that it is some kind of benevolent force in history that is "kept alive" by those who promote it. This can be illustrated by Iriye's account of the early-twentieth-century rise of the Esperanto movement. He refers to it as one of several non-governmental internationalist movements that sprang up in this period that strove to promote "international peace and

\footnotetext{
8 Ibid. p. 5.

${ }^{9}$ Iriye (nr. 4), 'Global Community: The Role of International Organizations in the Making of the Contemporary World,' p. 8.

${ }^{10}$ Ibid.
} 
understanding through cross-national communication". ${ }^{11}$ This may well be true, but if we assume with Anderson that the ideology of internationalism also has a history that consists of different and changing conceptions of what it meant for those who advocated it, Iriye's reference to the Esperanto movement leaves important questions unanswered, such as what kind of internationalism did the Esperanto movement advance? Did those involved all have the same conception of what constituted the international community that was supposed to be facilitated by Esperanto? For whom exactly was Esperanto? What did the actors gain from promoting Esperanto? To what extent were their notions of world orders an expression of national and/or regional interests? And to what extent did they share our conception of internationalism?

A closer look at the Esperanto movement exposes much more specific interests than Iriye allows for. It also shows a great variety of programs hiding under one umbrella term. Peter Glover Forster, for example, points out that the Esperanto movement consisted of a great variety of ideological programs and that Esperanto has been associated with a wide range of causes, but that it was especially popular among protestant and catholic groups. ${ }^{12}$ These promoted Esperanto as a means to unify the members of their communities. In 1902, for instance, a French parish priest called Emile Peltier founded the "Espero Katolika" (Catholic Hope) Society for the purpose of uniting Catholics, not humanity, all over the world. ${ }^{13}$ The Protestants also embraced Esperanto as a vehicle to unify their community. In 1906 Paul Hübner (1881-1970), a German Engineer, published a newspaper article titled "Esperanto en la servo de la Dia Regno" (Esperanto in the Service of God's Kingdom) in which he argued that the function of Esperanto was to internationally connect and unite Christian Esperantists. ${ }^{14}$

Not only Protestants and Catholics appropriated Esperanto to unify the members of their own communities. Esperanto's creator, the Jewish Polish physician Ludovic Lasarus Zamenhof (1859-1917), initially aspired to construct Esperanto as a modernized version of Yiddish. While at university he briefly became a Zionist. During this period he occupied himself with the question of how the Jews should relate to the rest of humanity. ${ }^{15}$ Zamenhof envisioned the creation of a Jewish colony and he argued that Esperanto could be taught there together with a philosophy called Hillelism. ${ }^{16}$ In doing so, he basically intended to use Esperanto to forge and enhance a communal Jewish identity in the same

\footnotetext{
${ }^{11}$ Ibid. p. 15.

${ }^{12}$ Forster, Peter G. (1982). The Esperanto Movement. Den Haag: Mouton Publishers. p. 234.

${ }^{13}$ Matthias, Ulrich (2002). The New Latin for Church and Ecumenism. Translated from Esperanto by Mike Leon and Maire Mullarney. Antwerp: Flandre Esperanto-Ligo. p. 43.

14 Forster (nr. 12), The Esperanto Movement, p. 234.

${ }^{15}$ Heynick, Frank (2002). Jews and Medicine: An Epic Saga. Hoboken, NJ: Ktav Publishing House, Inc. p. 306.

${ }^{16}$ Hillelism was Zamenhof's own creation. It was based on the teachings of a famous religious leader called Hillel the Elder (110BCE-10CE) who is considered as one of the most important figures in Jewish history. Hillel is associated with the development of the Nishnah and the Talmud and he is remembered as a liberal interpreter of the scripture. Zamenhof followed Hillel in stressing that the teachings of Moses were supposed to be practiced in spirit as opposed to in the letter.
} 
way national languages served as markers and transmitters of a shared sense of national identity.

Some Esperanto supporters even used it to express their reverence for their home nations. A typical example of this tendency could be found in the poetry of one of the earliest supporters of Esperanto, the Polish chemical engineer Antoni Grabowski (18571921). A poem titled "Daybreak" not only celebrated a new dawn for the "whole of humanity in each part of the world". The poem was also unmistakably a celebration of the home nation. For it made clear that there was no place like Poland, expressing a "(...) love for home, fatherland and nation". ${ }^{17}$

This multiplicity of ideological angles within the Esperanto movement makes clear that what 'international' encompassed and who were supposed to be the users of Esperanto was not, as Iriye suggests, an expression of a selfless and open "global consciousness". Instead, it was an expression of the interests and ideologies of particular communities, in this case including Protestant, Catholic, Jewish and national groups. Iriye also overlooks that internationalists commonly pursued nationalism through internationalism, as the Polish example shows.

Martin Geyer and Johannes Paulmann do point out that nineteenth- and earlytwentieth-century internationalist initiatives and organizations served special purposes that were defined in terms of nationalist agendas. The rhetoric of internationalism addressed an issue that appeared to concern the entire international community. But the point is that internationalist programs were not all-inclusive. More often than not "almost the reverse was true. The choice of location, for example, or even the construction of an international language related to existing inequalities". ${ }^{18}$

Geyer and Paulmann also make clear that the rise of world fairs, the creation of international standards for weights and measurements, money and time went hand-inhand with a redefinition of boundaries on a regional level: "In most cases internationalization during the nineteenth century meant, in effect, defining European standards as the internationally current ones, and in some cases it was only particular European countries that imposed their standards on international society" ${ }^{19}$ In other words, nineteenth-century international movements pursued the creation and/or consolidation of defined world orders to their own advantage, in that they consisted of a center and a periphery.

It is hard to let go of what is sacred. But a perspective on internationalist movements as expression of the interests of a particular community, nationality and/or a cluster of nations, offers a more realistic picture of what can be expected from them in the first place. Mazower, for instance, has powerfully demonstrated that it is relevant to take a

\footnotetext{
${ }^{17}$ Cited in, Forster (nr. 12), The Esperanto Movement, p. 68.

${ }^{18}$ Geyer, Martin \& Paulmann, Johannes (2001). 'Introduction. The mechanics of internationalism,' in Geyer, M. H. \& Paulmann, J. (ed.), The Mechanics of Internationalism. Culture, Society, and Politics from the 1840 s to the First World War, pp. 1-26. Oxford: Oxford University Press. p. 5.

${ }^{19}$ Ibid. p. 6.
} 
closer look at the conceptions and intentions of those who stand at the root of the creation of international movements and initiatives in the twentieth century for a better understanding of the ideological function in international affairs. He has shown this by exposing the imperial motives that underpinned the ideologies of the founders of the UN, one of the sacred cows of the post World War II era. ${ }^{20}$ In an earlier article Mazower has traced the conceptions of "European civilization" of the pioneers of the European state system, pointing out that they were "intellectual constructions riven with ambiguities. It [the notion of civilization] was a claim to power as well as a justification for violence. It was a hypothetical basis for global order in a world of hierarchy". ${ }^{21}$

\subsection{The sciences were never at war?}

While the functions of international initiatives and the narrow conceptions of past internationalist ideologies of politicians are starting to be exposed, this has not yet been done in the case of similar initiatives in which scientists played a leading role. The general picture of science as international endeavor par excellence continues to remain tightly anchored in the minds of both its practitioners and observers of scientific enterprise. Not surprisingly, in Iriye's Global Community scientists feature among the most ardent warriors for international peace and collaboration. Iriye points out, for instance, that after the League of Nations failed when it was unable to stop the Japanese aggression in China and the Italian conquest of Ethiopia, its advisory Committee on Intellectual Cooperation "never let up efforts to organize exchange programs, conferences, art fairs, and the like". ${ }^{22}$ We are also reminded that the same scientists that were involved in the construction of the atom bomb, including Robert Oppenheimer (1904-1967) and Albert Einstein (1879-1955), spearheaded the movement for international control over nuclear and other weapons in the aftermath of World War II in an attempt to renew science's commitment to internationalism. Not only that, Iriye also stresses the noble and exemplary character of their attempt, pointing out that: "Similar ideas had been expressed in the past - and had proved helpless against forces of destruction. But that did not prevent these scientists from trying yet again". ${ }^{23}$

The point is clear: scientists are different from politicians and ordinary citizens. By virtue of their focus on science they are supposedly not representatives of national

\footnotetext{
${ }^{20}$ Mazower, Mark. (2008). No Enchanted Palace: The End of Empire and the Ideological Origins of the United Nations. Princeton: Princeton University Press.

${ }^{21}$ Mazower, Mark. (2006). 'An international civilization? Empire, internationalism and the crisis of the midtwentieth century,' International Affairs (82)3: pp. 553-566.

${ }^{22}$ Iriye (nr. 4), 'Global Community: The Role of International Organizations in the Making of the Contemporary World,' p. 30.

${ }^{23}$ Ibid. p. 50.
} 
interests but of humanity as whole. For the idea is that in principle, national interests do not drive science. Or to quote the American physicist Karl K. Darrow: "In science there is hardly any nationalism". ${ }^{24}$ Just as NASA's claims about the ISS, the objective of interaction between scientists from different nationalities is to further our knowledge of the world, the universe, and her place in it. Science belongs to the whole of humanity, and what makes its practitioners so unique is that their motive is science itself. The idea is that as soon as its producers enter the lab, they have no other interest than to further our knowledge of the world.

In a recent CERN Courier article, titled 'The Internationalism of Science as an Ideal', Professor Thomas Walcher, who is one of the participating scientists in the CERN project in the field of particle physics, claims that: "Anyone who has worked there (CERN) will confirm that one loses one's nationality". ${ }^{25}$ Statements like this continue to present scientists and their practices as floating above national rivalries, suggesting that the practice of scientific collaboration takes place in a different realm. Knowledge is not restricted by national boundaries, and neither are those who deal in it. Such claims on the supposed disinterestedness of scientists and their work make scientific cooperation an appealing model for international politics. And what makes it especially appealing is that it has a history that endorses its exemplary nature.

Popular history teaches us that scientists have been disinterested ever since the birth of modern science in the seventeenth century in spite of powerful institutions that sought to obstruct their noble quest for knowledge. It is a commonly held assumption that before the rise of the nation, the church was science's primary enemy. The continuing popularity of Andrew Dickson White's (1832-1918) two-volume A History of the Warfare of Science with Theology in Christendom, first published in 1896, underlines the currency of this view. White argues that the church continuously sought to crush the progress of science since its inception in the seventeenth century. The two volumes serve up a seducing historical story of science's disinterestedness vis-à-vis the church through a narrative structure that highlights the opposition between the latter as a "prodigious theological engine of war", and the former as its unjustified victims. ${ }^{26}$

White's powerful tale, better known as the Conflict Thesis between religion and science, presents war mongering Church Fathers that used vicious and violent methods against early modern scientists. In a hopeless attempt to preserve power and influence, their methods included torture and death by the charge of atheism. But science's soldiers are depicted as selfless and heroic knights of reason and progress. Galileo Galilei's clash with the church features among countless historical examples of conflict between science

\footnotetext{
${ }^{24}$ Darrow, Karl (1943). 'Internationalism in Science', Science (28)2536: pp. 122-123. p. 122.

${ }^{25}$ Walcher, Thomas (2000). 'The internationalism of science as an ideal', The CERN Courier. Retrieved from the Worldwide Web on September $12^{\text {th }}, 2009$ : http://cerncourier.com/cws/article/cern/28359

${ }^{26}$ Dickson White, Andrew (2012[1869]). A History of the Warfare of Science and Theology in Christendom: From the Creation to the Victory of Scientific and Literary Methods. Piscataway, NJ: Transaction Publishers. p. 134.
} 
and the church to showcase the church's brutal use of war tactics against "the greatest man of science in that age". ${ }^{27}$ The church's 'victory' over the truth in its "struggle to crush Galileo" is portrayed as a brutal overkill. ${ }^{28}$ It involved being ordered before the Inquisition, being marked by a general denunciation, and the flooding of Europe with theological refutations of the Copernican system. The point is that the church acted merely out of selfinterest because it was desperately holding on to its power. Galileo and his comrades supposedly represented nothing less than the interest of humanity by furthering its progress though the spread of knowledge and reason. Their pursuit of a free inquiry in spite of the backwardness of their adversaries made them scientists, and the idea is that this quality connects these early pioneers of science with their modern day colleagues.

Paradoxically, the christening of science occurred at the demise of the church's power. As the co-founder of Cornell University, the first non-sectarian school in America, White's goal was to make clear that the church as an institution - not religion itself - was no longer welcome in the modern world. Science's battle with the church has been won since its early-twentieth-century demise. Ever since, in the eyes of many it has become the leading force of the modern world. As Steven Shapin has made clear: "Science continues to Make the Modern World. Whatever names we want to give to the leading edges of change - globalization, the networked society, the knowledge economy - it's science that's understood to be their motive force" ${ }^{29}$ The idea is that the thrust behind science's impact as a defining force of change is provided by an efficient international collaboration between its members and by the disinterested character of scientific products. They are said to work everywhere and anywhere. According to Alfred Whitehead's 1925 book Science and the Modern World, 'its [science's] home is now 'the whole world.' Science travels with unique efficiency: it is 'transferable from country to country, and from race to race, wherever there is a rational society'" ${ }^{30}$

But as soon as the demise of the church's power became a fact, science's exemplary history of disinterestedness was increasingly mobilized to criticize another powerful institution: the nation. Gavin de Beer's The Sciences Were Never at War from 1952 offers a typical account of scientists and science's historical national disinterestedness. De Beer argued that exactly because science had become such a powerful force, it needed pointing out that any harm it had caused in two world wars was caused by statesmen, not scientists: "What is sinister (...) is that in recent times some political systems have invaded the domain of science itself and distorted truth in order to control thought, on the principles which the Inquisition practiced against Galileo". ${ }^{31}$ Once again, the history of science teaches us that

\footnotetext{
27 Ibid. p. 137.

28 Ibid.

${ }^{29}$ Cited in, Shapin, Steven (2007). 'Science and the Modern World,' in The Handbook of Science and Technology Studies, 3rd Ed., Hackett, Edward \& Amsterdamska, Olga \& Lynch, Michael \& Wajcman, Judy (eds.), pp. 433-448 . Cambridge, MA: MIT Press. p. 434.

30 Ibid.

${ }^{31}$ De Beer, Gavin (1960). The Sciences Were Never at War.
} 
scientists were and are unique by virtue of their selfless and disinterested pursuit of knowledge. But this time they were opposed to the barbarous practice of statesmen of mobilizing science in the advantage of the nation. To quote de Beer: “(...) it is now generally accepted that secrecy in scientific progress may be a necessary part of national security for survival. There is nothing intrinsically barbarous in this than in war (...)". ${ }^{32}$

Just as White made clear that early modern learned men were not the same as the belligerent church fathers, de Beer's The Sciences Were Never at War makes clear that scientists are not the same as politicians and ordinary citizens. The book offers a radiant image of early modern scientists through a series of correspondence between learned men from France and Britain from 1690 to 1814, a period when these two countries were often at war. The letters illustrate what he calls "the international character of science" in such a way that it led one reviewer to describe the book exactly as how it was meant, namely as "a fascinating record of which science can well be proud". ${ }^{33}$ It serves up an image of scientists as completely detached from politics, in that they went about their normal business despite ongoing wars between France and Britain that severed the normal means of communication and travel:

They exchanged information on the results of their scientific work, they sent their publications, they travelled in each other's countries, asked for one another's good offices in securing the release of captured objects of scientific interests and of persons detained as prisoners of war, and elected one another to membership of the Royal Society of London and the French Academy of Sciences, war or no war. ${ }^{34}$

White's and De Beer's accounts of science's history as one of unwavering cooperation against a background of fighting politicians and theologians continues to hold sway over scientists and observers of science. But since the sixties it has come under attack by various historians of science.

In reaction to de Beer's account of scientific cooperation, Brigitte SchroederGudehus has exposed an episode of which science can be less proud in her book Les Scientifiques et La Paix: La Communaute Scientifique Internationale au Cours des Annees 20. In 1918 the Allied nations created a new structure of international scientific cooperation through the International Research Council that excluded German and Austrian scientists from participating. It was only after the Pact of Locarno in 1925 that cooperation between scientists from the Allied camp and scientists from Germany and Austria slowly developed.

\footnotetext{
London/Edinburgh/Paris/Melbourne/Johannesburg/Toronto/New York: Thomas Nelson and Sons Ltd. p. xiii.

32 Ibid.

${ }^{33}$ Hartley, Harold (1960). 'Science before the days of total war,' The New Scientist (7)177: p. 885.

${ }^{34}$ De Beer (nr. 31), The Sciences Were Never at War, p. ix.
} 
This slow restoration of international cooperation stood in strong contrast to other fields in the same period. In fact, by 1925 politicians, historians and philosophers had already restored their international networks. ${ }^{35}$

Focusing on the same episode, Daniel Kevles has shown that Allied scientists -especially the French and the Belgians - actively prevented their German counterparts from joining the IRC, which was established in by the American Astronomer George Ellery Hale (1868-1938) in 1919. ${ }^{36}$ Apparently emotions ran so high that, afraid to alienate the French and the Belgians, Hale even refused to accept cosponsoring by the German National Academy for a visit to America by Albert Einstein. ${ }^{37}$

In addition to refusing to resume cooperation with their neighbors, many scientists also played an active role in the war itself. Anne Rasmussen has pointed out that during World War I, leading scientists from France and Germany joined the theatre of war by producing war propaganda. ${ }^{38}$ Elsewhere she has shown that many scientists were just as eager to use their scientific skills to help win the war as their fellow countrymen. There was a general opinion in the scientific community that the military and politicians wasted their valuable skills, because it was thought they were unwilling or unable to incorporate these in the existing war apparatus. ${ }^{39}$ This sentiment was publicly expressed on numerous occasions by the French psychologist Henri Piéron (1881-1964), who was one of the founders of scientific psychology in France. Rasmussen points out that Piéron criticized the fact that the French army did not follow the Americans in their use of psycho-physiology for the assessment of recruits in the air force. ${ }^{40}$

Elizabeth Crawford has demonstrated that national interests also guided the peacetime practice of awarding prizes in the international scientific community. Crawford has done this by focusing on the Nobel Prize politics, a practice generally perceived as confirming the neutrality of science. In doing so, she pointed out that instead of being guided by science's supposed impartiality, scientists acted primarily as national representatives in nominations for the Nobel Prizes. ${ }^{41}$ In fact, her four studies reveal that between 1901 and 1939 Nobel internationalism functioned as a platform for furthering national interests in different ways. Firstly, during and after World War I, Nobel

\footnotetext{
${ }^{35}$ Schroeder-Gudehus, Brigitte (1978). Les Scientifiques et la Paix. La Communauté Scientifique Internationale au Cours des Années 20. Montréal: Les Presses de l'Université de Montréal.

${ }^{36}$ Kevles, Daniel. (1971). "Into hostile camps': The Reorganization of International Science in World War I,' Isis (62)1: pp. 47-60.

${ }^{37}$ Kevles, Daniel (1972). The Physicists: The History of a Scientific Community in Modern America. Cambridge: MIT press. p. 195.

${ }^{38}$ Rasmussen, Anne (2004). 'La science française dans la guerre des manifestes, 1914-1918,' Mots. Les langages du politique (76): pp. 9-23.

${ }^{39}$ Rasmussen, Anne. (2012) 'Science and Technology,' in: Horne, John. (ed.). A Companion to World War I, pp. 307-323. Malden, MA: Blackwell Publishing.

40 Ibid. p. 310.

${ }^{41}$ Crawford, Elizabeth. (1992). Nationalism and Internationalism in Science, 1880-1939: Four Studies of the Nobel Population. Cambridge: Cambridge University Press.
} 
nominations reflected an increase in national interests among scientists from warring nations. Secondly, in Central Europe there existed a scientific center and a periphery. Thirdly, in the United States an elitist conception of science played a role in the success of national science. And fourthly, national organizations made strategic use of the prestige of Nobel Prizes to further the cause of national science.

Focusing on the use of national languages by scientists and scholars in the Habsburg Monarchy in the late nineteenth and early twentieth century, Jan Surman also points at the persistence of nationalist agendas in what appeared to be an increasing orientation towards the international arena by issuing dual publications (one in the national language, the other in French or German, which was considered the international language of science). He points out that while there was a clear rise of an international publication culture in the scientific landscape of the Habsburg Monarchy in the last decade of the nineteenth century, scientists and scholars nonetheless continued to represent the national communities to which they belonged. Surman shows that language played a "pivotal" role in this process "by linking nationalistic ideology and the alleged international character of the scientific community". ${ }^{42}$

The combination of nationalism and internationalism in scientists' practices has received a thorough examination in the 1970 s by Paul Forman. To achieve some conceptual clarity about the ideology of scientific internationalism, he identifies the dynamics of national competition in scientific internationalism in the shared pursuit of quality in scientific performance by pointing out that such strivings have no meaning without an audience. The idea is that in the international scientific community the incentive for competition is to receive praise from competing nations. To quote Forman: "When, then, it is a question of measuring a nation's scientific achievement, the only standard legitimized by science itself is the relative amount of attention which that nation's scientific work attracts among foreign scientists". ${ }^{43}$ Forman argues that in this, science functions no differently than the Olympic games, which also functions as a platform for the distribution of prestige to the Olympic games.

Building on Forman's idea of scientific internationalism as an essentially competitive endeavor, Geert Somsen calls this conception "Olympic Internationalism" ${ }^{44}$ In doing so, he emphasizes Forman's assertion that instead of working in opposition to nationality, earlytwentieth-century scientific internationalism was in reality its very expression. The point is that while the turn of the twentieth century marked the rise of the international scientific

\footnotetext{
${ }^{42}$ Surman, Jan (2012). 'Science and its publics: Internationality and National Languages in Central Europe,' in Ash, Mitchell G. \& Surman, Jan (eds.), The Nationalization of Scientific Knowledgein the Habsburg Empire, 1848-1918. pp. 30-56. New York: Pallgrave Macmillan. p. 48.

43 Foreman, Paul (1973). 'Scientific Internationalism and the Weimar physicists: The Ideology and its manipulation after World War I,' Isis 64(2): pp. 151-180.

${ }^{44}$ Somsen, Geert (2008). 'A History of Universalism: Conceptions of the Internationality of Science from the Enlightenment to the Cold War,' Minerva (46)3: pp. 361-379. pp. 366-67.
} 
community, its institutions were, in fact, "meant to assess and acknowledge national scientific accomplishments". ${ }^{45}$

\subsection{Local to the core}

The above-mentioned studies have exposed an image of scientists as ordinary citizens who practiced their profession in national contexts. But observers of scientific internationalism continue to make a distinction between the political views of scientists on the one hand, and the content of scientific practice on the other. In Denationalizing Science, for instance, Terry Shinn, Elisabeth Crawford and Sverker Sörlin concede that the nation functions as the principal arena for modern science. But they nonetheless regard knowledge that is produced by the scientific community as universal. ${ }^{46}$ They claim that the core of the scientific enterprise remains inherently supranational. Echoing a weaker version of de Beer's claim that science has become corrupted by negative influence of nationalism, they argue that its inherent supranationality has nearly dissolved as result of a "complicated series of events involved with the growth of the nation-states $(\ldots){ }^{\prime \prime} .{ }^{47}$ Consequently, science "has become almost exclusively tied into the institutional and financial systems of these states". ${ }^{48}$ The introduction of a recent edition of the journal Science and Technology that is dedicated to the history of international collaboration between scientists offers a similar portrayal of science as essentially non-localized. In it, its editors claim that: "international cooperation has always been intrinsic to [science]" ${ }^{49}$

This conception of science presupposes a distinction between an external and internal side of science. Like the skin of a cell, the outer layer is permeable in that it allows the interests of the nation state to decrease science's universality by clouding the perception of its practitioners with national interestedness. But the inner layer of science consists of a nucleus of practices deemed impenetrable, unchangeable and therefore universal. It is the one and only place that is non-permeable. The idea is that despite the inevitable contamination of science through the external pressure of social interests, science's core values - objectivity and disinterestedness - remain unaffected by external values. Like the air in a surface buoy this supposedly pristine core pushes it towards the

\footnotetext{
45 Ibid. p. 367.

${ }^{46}$ Shinn, Terry \& Crawford, Elisabeth \& Sörlin, Sverker (eds) (1992). Denationalizing Science: The Contexts of International Scientific Practice. London etc.: Kluwer Academic Publishers.

${ }^{47}$ Shinn, Terry \& Crawford, Elisabeth \& Sörlin, Sverker (1992). 'The nationalization and denationalization of science. An introductory essay,' in Shinn, T. \& Crawford, E. \& Sörlin, S. (eds.), Denationalizing Science: The Contexts of International Scientific Practice, pp. 1-43. London etc.: Kluwer Academic Publishers. p. 3. 48 Ibid.

${ }^{49}$ Ausubel, Jesse H. \& Keynan, Alexander (2001). 'Foreword: the history of scientists' roles in international conflict resolution,' in Ausubel, Jesse H., Keynan, Alexander, and Salomon, Jean-Jacques (eds.), Technology in Society Special issue, Scientists, Wars and Diplomacy: A European Perspective (23)3: pp. 287-289. p. 287.
} 
surface of the muddy waters of social politics. This distinction between science's socially contaminated outside layer on the one hand, and its supposedly pristine universal core of disinterestedness on the other, ignores significant work done by historians and sociologists of science under the Strong Program. For them the notion that scientific knowledge is local and culturally embedded has become a benchmark.

Emerging in the seventies and early eighties, practitioners of the Strong Program are currently too manifold too cite here. But one of the classic studies in this tradition is Steven Shapin's and Simon Schaffer's Leviathan and the Air-pump (1985). Instead of viewing Robert Boyle's (1627-1691) air-pump experiments as being detached from politics, Shapin and Schaffer point out that the way they were supposed to be set-up, conducted, reproduced and interpreted by its practitioners, was itself political, in that it was supposed to express the principles of good governance in seventeenth- century English culture. Boyle's novel emphasis on the detailed and modest presentation of facts, which enabled the larger community of learned men to witness and reproduce the procedures being performed, was a means to create a battle free zone of facts that gave those who established them political legitimacy in the restoration period. In doing so, they used their objective language and adherence to modesty to distance themselves from sectarian enthusiasts and other radicals that threatened the political order. In other words, politics were intrinsically tied up in what early modern scientists did.

Taking the implications of Shapin's and Schaffer's conclusions to a more general level, David Livingstone's Putting Science in its Place (2003) contains an explicit attack on the notion that science is something that floats free of culture. ${ }^{50}$ Livingstone, who is a geographer, surveys locations where scientific work was done, including concrete places such as the laboratory, the field, botanical gardens, the human body, and of course regions of which the principle cases are differing national contexts in which European science developed. In doing so, he shows that scientific work and knowledge are deeply imbedded in specific times, places, and local cultures. Science, he concludes, is not a placeless activity, in that it does not involve the liberated travel of transparent truths from their local context of discovery. The universalization of scientific knowledge is the result of a standardization and reproduction of experiments and methods that were crafted in a particular time and place. In other words, the dissemintation of science does not occur automatically, in that it requires an active process of reproducing local practices in a different setting.

\footnotetext{
${ }^{50}$ Livingstone, David, N. (2003). Putting Science in its Place: Geographies of Scientific Knowledge. Chicago: Chicago University Press.
} 


\subsection{A world unified through science}

Adding up studies on science and internationalism and studies done under the Strong Program, the image of scientists as innate internationalists and of science as inherently universal has been sufficiently debunked. My study will stand firmly in the tradition of viewing science as an inherently local endeavor. But unlike most studies in the tradition of the Strong Program, its primary object will not be the politics of the practice of scientific knowledge production; nor will this be an attempt to debunk scientific internationalism as a myth. Its central object will be the use of that myth, the life of the ideology of internationalism.

In order to understand that ideology we need to ground it historically. To that end, this dissertation zooms in on a remarkable episode in the story of scientific internationalism, consisting of a series of attempts in the early-twentieth-century to create, promote and institutionalize an international scientific language. Notable advocates of such a language were the French mathematician and logician Louis Couturat (1868-1914), the German chemist and Nobel laureate Wilhelm Ostwald (1853-1932), and the American physical chemist, inventor and philanthropist Frederick Gardner Cottrell (1877-1948). In 1901 the first two formed a "Delegation for the Adoption of an International Auxiliary Language", which developed a language called Ido in $1907 .{ }^{51}$ In 1919 , Cottrell revived the pursuit as a member of new International Research Council, which he convinced to start a Committee on International Auxiliary Language as well.

Couturat, Ostwald and Cottrell claimed that scientists faced increasing communication problems at international conferences and in journals because of a spectacular rise of multiple national languages in the scientific community. Their solution was to create and promote an artificial language that was supposed to supplant this diversity by becoming an international standard for the communication of science. The Esperanto movement played a formative role on this initiative, in that it introduced the protagonists to the idea of an artificial international language, and formed the basis for the language they would develop. In fact, the name Ido was derived from the Esperanto word "ido", meaning offspring.

What made the pursuit of our protagonists different from Esperanto were its scientific associations. Their language was meant for science in that it would assist the international flow of knowledge, even outside academia in the world of trade. At the same time they presented it as being of science, in that it was the expression of its rationality and international character. "Scientific" methods and principles guided the creation of Ido out of existing languages. Delegation members conducted linguistic experiments, they "rationalized" grammar by stripping it of useless rules, and they selected new verb stems according to the "principle of maximum internationality". The result was "a purified and idealized extract, a quintessence of the European languages" - which relieved

\footnotetext{
${ }^{51}$ According to Couturat this delegation was appointed at the First International Congress of Philosophy in Paris in 1900 with the task of exploring the possibilities of an international language.
} 
communication of the dead weight of needless, irrational complexities that characterized existing national languages. ${ }^{52}$ Its users - no matter where they were from - would experience this newly forged language as neutral as a result of a careful scientific assemblage and selection. They also claimed that it was a more precise vehicle than any existing language for the international transfer of knowledge, for it exhibited a mathematic precision and accuracy that was found only in the sciences.

The three scientific international language advocates not only claimed that their language facilitated a smoother international communication of scientific knowledge. They also presented it as a tool for international affairs in general - as both an ideal form of international communication and a pedagogical tool teaching communication to its users. Its rationalized grammar and scientifically selected vocabulary would help users to communicate more clearly and efficiently. Driven by this conviction, they viewed it as their calling to promote their language as a critical stepping-stone towards a rationally organized - and therefore more peaceful - world order.

Such attempts to build a new international order on the basis of science's supposed rationality were not unique. According to Mark Mazower, who has mapped out various strands of internationalism, this scientistic kind was in fact quite typical of the age:

Its an old idea, this thought that all would be well if only the politicians could be kept at arm's length and the people who actually know something allowed to get on with things. Before World War I, scientists, engineers, doctors and bibliographers all embraced internationalism for this reason: it gave them a grand mission and appealed to their sense of the nobility of their calling. ${ }^{53}$

Mazower categorizes this "Science the Unifier" movement as one of several internationalisms that developed against the backdrop of the Concert of Europe in 1815: the peace movement, free trade advocacy, nationalist internationalism, communism, and the Red Cross and arbitration movements. ${ }^{54}$ What distinguished scientific internationalism

\footnotetext{
${ }^{52}$ Couturat, Louis (1910). 'On the Application of Logic to an International Language', in Couturat, L. \& Jespersen, O. \& Lorenz, R. \& Ostwald, W. \& Pfaundler. L. International Language and Science: Considerations on the Introduction of an International Language into Science, pp. 42-52. Translated by Donnan, F.G. London: Constable and Company Limited. pp. 51-52.

${ }^{53}$ Mazower, Mark (2012). 'What Remains: On the European Union,' The Nation September $5^{\text {th }}$. Retrieved from the World Wide Web on September 9th, 2012: http://www.thenation.com/article/169756/what-remainseuropean-union

${ }^{54}$ All of these internationalisms were both modelled upon and reacted against the The Concert of Europe, the great powers' congress system that was established in the wake of Napoleon's defeat. What they rejected in the Concert was its aim to maintain the balance of power by restoring old souvereigns, controlling revolutionary insurgencies and reinstating monarchies. What they adopted was the general rhetoric of
} 
from most other internationalisms was that it did not imply the removal of the state. While communists, nationalists and other internationalists opted for radical political changes, their scientific fellows wanted to retain government as it was, only to take it out of the hands of amateurs and old-fashioned war-mongering politicians and place it into the hands of a rational elite and their rationalized, and therefore civilized, forms of communication and organization:

Across a range of new professions - statistics, engineering, geography, bibliography, public health - men emerged who did not want to do away with the state but to take it over, to replace aristocracy with a professional meritocracy, to push aside the well-connected amateurs and bring in new cadres of educated and rational elites. ${ }^{55}$

According to Mazower the "Science the Unifier" movement is epitomized by the work of the Belgian lawyers Paul Otlet (1868-1944) and Henri Lafontaine (1854-1943). In his view, their internationalist project represents almost all the characteristics of early-twentiethcentury scientific internationalism. It is therefore instructive to briefly compare their work to that of the international scientific language advocates.

No doubt, the campaigns of Otlet and Lafontaine belong to the most captivating internationalist endeavors of that period. For nearly half a century they sought to unify mankind through the assemblage, organization and dissemination of the world's knowledge. Science, they claimed, had thus far expanded in an uncontrolled and internationally uncoordinated fashion, and what was required was a rational system of storage and retrieval. To perform this task Otlet and Lafontaine initiated a series of bibliographic measures. These included the collection of information on index cards and the creation and implementation of a classification system called the Universal Decimal Classification system (UDC). ${ }^{56}$ The UDC was a remodeled version of Dewey's classification

international collobartion. Mazower, Mark (2012). Governing the World: The Rise and Fall of an Idea. New York: Penguin Books Limited. p. 9.

55 Ibid. p. 95.

${ }^{56}$ For work on Paul Otlet and Henri Lafontaine's internationalism, see, Laqua, Daniel (2009). 'Transnational Endeavors and the Totality of Knowledge: Paul Otlet and Henri La Fontaine as "Integral Internationalists" Finde-Siècle Europe', in Grace Brockington (ed.), Internationalism and the Arts in Britain and Europe at the Fin de Siècle, pp. 247-71. Peter Lang: Oxford. For work on Paul Otlet, see, Vanacker, Wouter (2011). 'Internationalist utopias of of visual education. The graphic and scenographic transformation of the universal encyclopedia in the work of Paul Otlet, Patrick Geddes, and Otto Neurath,' Perspectives of Science 19(1): pp. 32-80; Acker, Wouter (2011). Universalism as Utopia. A Historical Study of the Schemes and Schemas of Paul Otlet (18681944). Unpublished PhD Dissertation. Zelzate: University Press; Acker, Wouter \& Somsen, Geert (2012). 'A tale of two world captitals - the internationalisms of Pieter Eijkman and Paul Otlet,' Revue Belge de Philologie et d'Histoire/Belgisch Tijdschrift voor Filologie en Geschiedenis 90 (4): 181-201; Rayward, Boyd (1975). The Universe of Information: the Work of Paul Otlet for Documentation and International Organization. FID 
system. Otlet and Lafontaine claimed that one of its revolutionary features was its extensive notational system with symbols and syntax rules that supposedly enabled the creation of a documentation system with a logical structure. They also held that it contained a much larger vocabulary and syntax than Dewey's system, allowing for more specified content indexing and therefore more precise information retrieval.

In 1910 Otlet and Lafontaine created the Union of International Associations, which included the International Office of Bibliography (IOB). ${ }^{57}$ The $1 \mathrm{OB}^{\prime}$ 's function was to centralize information that was produced in an increasing number of nations into a catalogue that was organized with the UDC. ${ }^{58}$ They established another institution called the Mundaneum, which housed this catalogue and was meant to disseminate its information. ${ }^{59}$ Otlet presented the Mudaneum as a neutral center of a pacified world. ${ }^{60} \mathrm{He}$

Publication 520; Moscow: Published for the International Federation for Documentation by the All-Union Institute for Scientific and Technical Information (Viniti); Rayward, Boyd (1991). 'The case of Paul Otlet, pioneer of information science, internationalist, visionary: reflection on biography,' Journal of Librarianship and Information Science 23: 135-145; Rayward, W. Boyd. (1994). 'Visions of Xanadu: Paul Otlet (1868-1944) and Hypertext,' Journal of the American Society for Information Science (45): pp. 235-250. Rayward, Boyd (1997). 'The origins of information science and the International Institute of Bibliography/International Federation for Information and Documentation (FID),' Journal of the American Society for Information Science 48(4): pp: 289-300; Rayward, Boyd (2003). 'Knowledge organisation and a new world polity: the rise and fall and rise of the ideas of Paul Otlet,' Transnational Associations (1/2): pp. 4-15.

${ }^{57}$ In 1895 Otlet and Lafontaine established the forerunner of the IOB, which was called the International Institute of Bibliography (IIB). Rayward, Boyd (1997). 'The origins of information science and the International Institute of Bibliography/International Federation for Information and Documentation (FID),' Journal of the American Society for Information Science 48(4): pp: 289-300. p. 291.

${ }^{58}$ Otlet envisioned the Union of International Associations as part of a larger architectural conglomerate of institutions and associations that included an international library, an international museum, an international university and a central service for international associations that was to serve as a information and documentation center of the world's international organizations. The conglomerate itself would constitute a vibrant world city that formed the cultural heart of a harmonious international order. Leopold II, King of the Belgians, stimulated this development of his capital as a host of professional, non-profit, and scientific international organizations. In fact, Otlet and Lafontaine believed that their union was a means to further encourage this trend. They claimed that its activities helped their country to achieve the international prestige as a central harbor for the international community their King desired. Rayward, Boyd (1975). The Universe of Information: the Work of Paul Otlet for Documentation and International Organization. FID Publication 520; Moscow: Published for the International Federation for Documentation by the All-Union Institute for Scientific and Technical Information (Viniti). p. 172.

${ }^{59}$ Otlet envisioned it to be housed in a tower of progress that "majestically rises towards the skies, monumental symbol of progress of drawing humanity towards a common center where interest will be sheltered and protected". Cited in, Chabard, Pierre (2008). 'Towers and Globes: Architectural and Epistemological Differences between Patrick Gedde's Outlook Towers and Paul Otlet's Mundaneums,' in Rayward, W. Boyd (ed.), European Modernism and the Information Society: Informing the Present, Understanding the Past, pp. 105-126. Alderschot, UK: Ashgate Publishing. p. 122.

${ }^{60}$ Otlet stated about the ideological and geographical centrality of the Mundaneum that: "Our desire is that from a point on the Globe, the total image and the significance of the World can be perceived and understood; that this point becomes a sacred, inspiring place and coordinator of great idea and noble activities". Cited in, Chabard (nr. 61), 'Towers and Globes: Archtectural and Epistemological Differences 
claimed that its aim was to become "a complete survey of human knowledge, as an enormous intellectual warehouse of books, documents, catalogues and scientific objects" ${ }^{61}$

Otlet argued that his knowledge project was simply a matter of capturing objective facts and making them accessible through an internationally standardized system. Classifying and organizing were neutral procedures that simply made knowledge accessible without any personal bias or political interests. Otlet assumed that true knowledge was objective and already established, forming a neutral basis for a new world. His biographer Boyd Rayward points out that:

Otlet's concern was for objective knowledge that was both contained and hidden by documents. His view of knowledge was authoritarian, reductionist, positivist, simplistic - and optimistic! (...) It is merely a question of institutionalizing certain processes for analyzing and organizing the content of documents. For him the aspect of the content of documents with which we must be concerned is facts. He speaks almost everywhere of facts. $^{62}$

Otlet's notion of knowledge is comparable to our protagonists' notions of knowledge. These can also be described broadly as authoritarian, reductivist, positivist and optimistic. They claimed that the application of scientific methods to the creation of their language simply synchronized it with the knowledge it was meant to transport. It supposedly did this by ridding it off the superfluous complexities that characterized national language. This argument closely resembled Otlet's claims about the UDC as capturing knowledge more efficiently and without any biases. Otlet and the scientific international language exponents also shared the claim that their instrument was truly neutral, and therefore international, because it corresponded more directly to the international character of scientific knowledge than other system.

At first glance then Mazower seems right in presenting Otlet's and Lafontaine's project as typical of the entire "Science the Unifier" movement. But in the process of distinguishing this movement from other internationalisms at the time, Mazower neglects the differences within scientific internationalism. These differences can be seen to manifest themselves at two levels. Firstly the ways in which science was supposed to be an

\footnotetext{
between Patrick Gedde's Outlook Towers and Paul Otlet's Mundaneums,' p. 122.

${ }^{61}$ Otlet, Paul (1990[1914]). 'Union of International Associations: A World Centre,' in Otlet, Paul \& Rayward, Boyd (ed.), International Organization and Dissemination of Knowledge. Selected Essays of Paul Otlet. Translated and Edited with an Introduction by W. Boyd Rayward, pp. 116-129. Amsterdam/New York/Oxford/Tokyo: Elsevier Science Publishing Company Inc. p. 116.

${ }^{62}$ Rayward, W. Boyd (1994). 'Visions of Xanadu: Paul Otlet (1868-1944) and hypertext,' Journal of the American Society for Information Science (45): pp. 235-50. p. 247.
} 
instrument in international unification varied. Secondly, internationalists pursued different ideological aims and agendas - they disagreed on what the use of science should lead to.

The instrumental diversity is illustrated by the scientific international unification program of George Sarton (1884-1956), the Belgian-American founding father of the history of science. Sarton promoted the history of science itself as a pedagogical instrument to establish an international world order. ${ }^{63}$ Sarton developed his internationalist ideas in the same intellectual circles as Otlet and Lafontaine operated, whom he avidly (but by no means uncritically) supported. ${ }^{64}$ For a brief period he also expressed an interest in Ido, claiming that not Esperanto, but Ido was "the most perfect and simplest international language". ${ }^{65}$ Sarton claimed, however, that without a moral guide for how science was to be used for the benefit of mankind, there remained the risk that it was used in the wrong way. He argued that exactly because science was the only truly international and progressive human activity, there could be no other moral guide for humanity than its history. Science's history therefore needed to be served up as a sort of positive mirror for the whole of humanity. ${ }^{66}$ In other words, whilst Otlet and Lafontaine focused on the bibliography of science, Sarton focused on history of science as an instrument towards international unitification

It is important to look at the instrumental differences between scientific internationalist projects. In the last chapter of this dissertation I will show that in order to get a better understanding of the mechanics of internationalism, it matters to take into account that the project of our protagonists was a linguistic endeavor, and not a bibliographic or a historic one. Our protagonists' use of language to promote international community occurred in a period during which language had become a principle identifier for national identities. As such, language had become a means to define and maintain national communities in the hand of nationalist agitators. The relationship between this nationalist strategy and the linguistic internationalism of our protagonists deserves a closer look.

What is also problematic about Mazower's depiction of the "Science the Unifier" movement is that it is homogeneous on an ideological level. Scientific internationalists'

\footnotetext{
${ }^{63}$ Sarton pursued this mission in two ways. In 1913 he established Isis as the first international journal for the history of science and he worked on a synthetic history of science. He moved to the US in 1915 after the Germans invaded his hometown Ghent. to the US. There he worked on this second project as librarian of the Widener Library at Harvard until his death in 1954.

${ }^{64}$ For more on Sarton's efforts to promote the history of science, see, Bert Theunissen, 'Unifying science and human culture: the promotion of the history of science by George Sarton and Frans Verdoorn,' in Somsen, Geert \& Kamminga, Harmke (eds.), Pursuing the Unity of Science: Ideology and Scientific Practice Between the Great War and the Cold War (Aldershot: Ashgate Publishing, forthcoming).

${ }^{65}$ Cited in, Pyenson, Lewis \& Verbruggen, Christophe (2009) 'Ego and the International: The Modernist Circle of George Sarton,' Isis (100): pp. 60-70. p. 68.

${ }^{66}$ Sarton descibed war as a "temporary regression" and during which science was applied to the detriment of humanity. Sarton, George (1919). 'War and Civilization,' Isis (2)2: pp. 315-321. p. 316.
} 
common aim to achieve a rational and efficient world order appears to reflect a shared ideology. Moreover - and this is another problematic feature - this shared conviction seems to be politically neutral. All scientific internationalists pursued, in Mazower's description, was a more efficiently integrated world. But what that meant, how it was conceived, whom it put in the lead, and what interests it served is left out of the story. And different actors might have given very different answers to these questions.

On the surface, Couturat's, Ostwald's and Cottrell's promotions of international scientific language certainly fit Mazower's general description of the ideology of the

"Science the Unifier" movement. But by zooming in on their individual projects, I will show that at a deeper level their engagement was a product of differing ideological agendas. Each of them had a different conception of what scientific internationalization was and should lead to. Moreover, as I will argue, their various international language pursuits were less driven by the pull of demand than by the push of their own, individual political agendas.

To expose the diversity of ideological and political motives that underpinned the engagement for a scientific international language of our protagonists, I will describe the personal, disciplinary and national contexts of the language pursuits of each of them in chapters II, III and IV. I will do this by following the protagonists from the various social contexts, places and events that started their involvement with international language until it ended. This multiplicity allows me to disengage the actors' projects from the rhetoric of international need, and to complement it with accounts of individual motives. It enables me, in other words, to localize internationalism as a product of three individual ideological programs.

\subsection{Framing the case study}

There is relatively little literature on science and international language in the early twentieth century. In fact, Anne Rasmussen has conducted the only serious examination of this episode. Rasmussen considers Couturat's project, detailing several of his arguments for creating Ido in the context of several 'rivaling' contemporary international projects. These include Esperanto, attempts to revive Latin as international language as well as more common calls for the adoption of a single national language as a means for international communication. Rasmussen claims that a dramatic late-nineteenth and early-twentiethcentury rise in national languages in the international scientific community pulled Couturat, Ostwald as well as other international language proponents to solve this problem by imposing a single language. As pointed out, however, in the light of more recent literature on the mechanics of internationalism, it is apparent that Rasmussen's account scratches the surface in terms of the personal and especially political motives and interests that pushed the protagonists to pursue their internationalist programs. 
Moreover, Rasmussen's argument is based on the assumption that the problem of international language diversity was considered an urgent matter among early-twentiethcentury scientists. This was not the case. Roswitha Reinbothe has pointed out that if at all they had an opinionon the subject, they held two positions. They either accepted the status quo of French, English and German as the dominant languages in science, or they viewed one of these three languages a superior language for both international science and international relations. ${ }^{67}$ The second view was most commonly held among native speakers of the language in question. So Couturat, Ostwald and Cottrell clearly stood out by actively and consistently promoting a language that was artificially created out of existing languages by using scientific methods. And we will see that they pursued this program despite a continuous lack of support for their projects in the scientific community.

In order to unearth the motives and conceptions that constituted the ideological agendas that pushed them to intervene, each chapter chronologically reconstructs our protagonist's involvement with international language, tracing its development from their first contact with the idea until their involvement with it ended. In doing so, this study aligns itself loosely with the principles of transnational history. Transnational history, which distinguishes itself by studying historical processes above and beyond the structures of states and nations, has gained widespread popularity in the historical discipline. ${ }^{68}$ The transnational turn in the study of history began in the early 1990s under the influence of a changing geopolitical situation. The collapse of the Soviet Union and the burgeoning social sciences scholarship about "globalization", a reference to a new interconnectedness in the

\footnotetext{
${ }^{67}$ Roswitha Reinbothe's compelling account of the demise of German in the international scientific community since World War I underlines the existence of this linguistic triptych before 1914. Reinbothe briefly mentions Couturat's and Ostwald's efforts to promote Ido as exceptions in the early-twentieth-century linguistic landscape in international science. See especially, Reinbothe, Roswitha (2006). Deutsch als internationale Wissenschaftssprache und der Boykott nach dem Ersten Weltkrieg. Frankfurt am Main: Verlag Peter Lang. See also, Reinbothe, Roswitha (2010). 'L'exclusion des scientifiques allemands et de la langue allemande des congrès scientifiques internationaux après la Première Guerre mondiale,' Revue Germanique Internationale (12): pp. 193-208.

${ }^{68}$ A World Connecting: 1870-1945 (2012), part five of the monumental series A History of the World, underlines the present currency of the transnational history approach. It consists of five book-length contributions by a group of internationally renowned historians that deal with global connections rather than separate geographical units. Each chapter addresses a separate theme. These include modern state building (Charles Maier), imperialism (Antoinette Burton and Tony Ballantyne), migration (Dirk Hoerder), commodity chains (Steven Topik and Allen Wells) and transnational and social networks (Emily Rosenberg). Rosenberg, who is also the volume's editor, makes clear in the introductory chapter that the contributors share that they conceive of the "terrain of the world as radiating from no single region but as best understood through the variety of social, cultural, political, and economic exchanges and networks that linked (or failed to link) people". The result is a dynamic interpretation of the world between 1870 and 1945 that reveals how regional, national and imperial borders were constantly recreated and asserted by framing them at the crossroads of the period's transnational connections of institutions, movement of peoples. Rosenberg, Emily (2012). 'Introduction,' in A World Connecting: 1870-1945, vol. 5 of Iriye, Akira \& Osterhammel, Jürgen (gen. eds) \& Rosenberg, Emily (ed.), A History of the World (6 vols), pp. 3-25. Cambridge, Mass: Harvard University Press. p. 8.
} 
world made possible by global capital and information technology, prompted historians to look differently at history. As a result, they began to increasingly challenge the long-held assumption that the nation is the basis unit of historical analysis. ${ }^{69}$

In an attempt to move beyond the nation as an exclusive frame of reference, transnational historians define it as something that is itself produced and sustained in a global context. They do this by examining past phenomena (institutions, ideas, things, people and practices) not as static and territorially fixed, but as dynamic products of circulating entities and connections. Akira Iriye and the French historian Pierre-Yvess Saunier are two leading scholar in this field. They point out that transnational history pays special attention to the "circulations and connections between, above and beyond national politics and societies" by zooming in on the "flows of people, goods, ideas or processes over borders". ${ }^{70}$

In what follows, the ideological programs that propelled our three protagonists to promote international language are explored as products of the interplay of scientific conceptions and political motives they picked up and pursued as they operated in different contexts and settings beyond, at and below the level of the nation.

Their activities as scientists, scientific organizers and politically engaged intellectuals brought them to foreign research sites, world's fairs, international conferences and international exchange programs. The components that made up the ideological programs that propelled their engagement will be traced in these places beyond the nation. But it is also shown that their interactions and claims at an international level involved the assertion of interests and idea that were forged at the level of the nation, in that these were expressions of nationalistic and imperialistic agendas. And finally, their ideological programs are traced as both expressions of and stakes in debates and issues that occurred below the level of the nation.

The first half of chapter $V$ develops an image of early-twentieth-century linguistic scientific internationalism as an expression of differing ideological programs, comparing and discussing the contours and political functions of their programs. It is argued that the linguistic internationalisms of our protagonists was driven by a combination of on the one hand a shared familiar positivist notion of scientists as standing at the pinnacle of civilization, and on the other three different notions of how their programs contributed to securing and/or maintaining the status of their nations as the pinnacle of the international civilization.

The approach of historically grounding the internationalism of our protagonists as expressions of diverging political agendas is rewarding, in that it exposes the power politics that propelled it. But as mentioned in the previous paragraph, there is another way to

\footnotetext{
${ }^{69}$ For an extensive history of the transnational history approach, see, Iriye, Akira (2013). Global and Transnational History: The Past, Present and Future. New York: Palgrave Macmillan.

${ }^{70}$ Iriye, Akira. \& Saunier, Pierre-Yvess (2009). 'The professor and the madman,' Introduction in The Palgrave Dictionary of Transnational History. Retrieved from the Worldwide Web on September $14^{\text {th }}, 2012$ :

http://www.transnationalhistory.com/about.aspx?id=1420
} 
interpret campaign for a scientific internationalism language, which is as a strategy of community building on an international level. To do this, the second half of chapter $\mathrm{V}$ examines our protagonists' linguistic internationalism by drawing on insights from social constructivist studies on the use of language in the formation of nations. In doing so, I will argue that while the three protagonists broke the association of language with nationalism, they actually copied the nationalist use of linguistic means for defining and promoting community. But instead of fostering a shared national identity, they mobilized it to foster a shared international identity. 


\section{CHAPTER 2}

\section{Beyond Babel: Louis Couturat's creation and promotion of Ido}

Louis Couturat was born four years before Russell in 1868 in the French town of Ris-Orangis in Essonne. In 1890 and 1892 he obtained his degrees in philosophy and mathematics at the Ecole Normale Supérieure in Paris, where prominent mathematicians as Poincaré, Émile Picard (1856-1941) and Jules Tannery (1848-1910) were among his teachers. He was a French promoter of symbolic logic, a science of developing and representing logical principles with a formalized system made of primitive symbols more commonly known as mathematical logic. His involvement in this field brought him in touch with numerous wellknown mathematicians and logicians, including Bertrand Russell (1872-1970). Couturat was an active popularizer of the former's mathematical work in France. He was also one of the first scholars to explore Gottfried Wilhelm Leibniz's Nachlass in Hanover. His two books on Leibniz's work - La Logique de Leibniz (1901) and Opuscules et Fragments Inédits de Leibniz (1903) - are still considered important in the field of Leibniz scholarship.

But in contrast to Russell, who went on to become one of the most famous philosophers in the twentieth century, Couturat remains a relatively unknown figure in the history of mathematics and philosophy. He is, however, well remembered among Esperantists as the man who initiated an attack on their language by creating and promoting Ido as its improved version. This episode earned him a role in the latest novel by the American historical fiction writer Joseph Skibell as the man who "in hoping to reform 
Esperanto, destroyed it altogether" ${ }^{1}$ This intervention also earns him a prominent role in this dissertation.

Couturat's road to infamy started in 1900. From that year onwards he became engaged in a battle against the inefficiencies created by the diversity of national languages at international scientific conferences and in scientific journals. In 1901 he formed a Delegation for the Adoption of an International Auxiliary Language (DAIAL). It brought together a range of linguists, scientists, and other scholars, who joined forces in a series of negotiations to generate an international language. ${ }^{2}$ In 1907 the DAIAL proposed Ido. Couturat argued that Ido was simply more neutral and efficient by virtue of the scientific methods with which it had been created. He claimed that with these qualities it was exactly what was needed to facilitate a smooth international transfer of scientific knowledge, because valuable scientific knowledge was wasted as it fell between the cracks of incompatible vernaculars. At the same time, Couturat presented Ido as a politically neutral language, in that its scientific basis was supposed to take it above national politics. Its vocabulary he said was chosen according to "the principle of maximum internationality" and a grammatical structure that was said to be freed from useless rules and confusing exceptions, Ido was, to use Couturat's description, "nothing but a purified and idealized extract, a quintessence of the European languages". ${ }^{3}$

As pointed out in chapter $\mathrm{I}$, this reconstruction of Couturat's linguistic internationalism seeks to flesh out a historically grounded image of scientific internationalism by framing his linguistic internationalism as an expression of an individual ideological program. Structurally, my argument is developed in eight sections. Section 1 introduces our protagonist a little more extensively and it discusses his first involvement with international language. Section 2 presents his claims for the necessity of an international language. Section 3 offers a brief account of the mechanics of Ido and its supposed scientific and political virtues. Section 4 points out that Couturat's linguistic internationalism was more driven by the push of individual ideological motives than by the pull of external demand. Section 5 argues that one of the components of Couturat's program was a typically late nineteenth notion of scientific objectivity that was pursued by

\footnotetext{
${ }^{1}$ Skibell, Joseph. 'Stephen F. Foster, Historical Truth \& Novel.' Retrieved from the World Wide Web October $1^{\text {st }}$, 2012: http://www.wondersandmarvels.com/2010/08/stephen-f-foster-historical-truth-the-novel.html

${ }^{2}$ The delegation included the following members: Wilhelm Ostwald (German Chemist), Wilhelm Foerster (German astronomer and President of the International Committee for Weights and Measures), Manuel Barrios (President of the Peruvian Senate), Baudouin de Courtenay (Professor of Linguistics, University of St. Petersburg), Emile Boirac (French author and Esperanto supporter), Charles Bouchard (Professor of medicine, Paris College of Medicine), Roland Eotvos (physicist, Hungarian Academy of Sciences), George Harvey (Esperanto supporter and editor of the North American Review), Otto Jespersen (philologist, University of Copenhagen), Spyridon Lambros (Historian, University of Athens), Constantin Le Paige (Mathematician, University of Liege), Hugo Schuchardt (linguist, University of Graz).

${ }^{3}$ Couturat, Louis (1910). 'On the Application of Logic to an International Language', International Language and Science: Considerations on the Introduction of an International Language into Science, Couturat, L. \& Jespersen, O. \& Lorenz, R. \& Ostwald, W. \& Pfaundler. L. London: Constable and Company Limited. p. 51-52.
} 
a small group of mathematicians, philosophers, and logicians. The next section argues that a political conviction that was forged in reaction to the famous French Dreyfus Affair was another component of his ideological program. Section 7 argues that while Couturat claimed that he was inspired by Leibniz's efforts to create a universal symbolic language project, he actually invented an image of Leibniz as an early-twentieth-century scientific internationalist. The last section concludes with a final consideration of Ido as Couturat's attempt to reassert the French Republic's position as a leading nation in the international community.

\subsection{Couturat's dream}

The dream of an international scientific language seems eccentric from a current-day perspective. But at the end of the nineteenth century such a dream, whether it was an existing national language, a revival of Latin, or the creation of an artificial language, was a familiar one. During the second half of the nineteenth century, at least 38 international language projects were initiated. ${ }^{4}$ The dream of World English was one of the most prominent attempts to internationalize a national language. Esperanto and Volapük were the most successful attempts to promote an international artificial language. In the previous chapter we saw that Zamenhof created Esperanto in 1887. In 1897 a German Catholic priest named Johann Martin Schleyer (1831-1912) created Volapük, which was mostly displaced by Esperanto in the early twentieth century.

What distinguished Couturat's language project was that he presented it as a scientific language. Besides being intended for commerce and politics, it was not only primarily meant for scientific conferences and publications. It was also an expression of the virtues of science itself, because it supposedly displayed a high degree of precision and simplicity.

Couturat's first step towards the promotion of such a language began in Paris in 1900 at the First International Congress of Philosophy. The congress was organised on the occasion of the Paris world's fair to promote international communication among philosophers. Emile Boutroux's pompous opening speech reveals the ambitious nature of the event, making clear that "the impressive advances achieved in our century make possible a much more sophisticated intertwining of minds than was ever conceivable in the past". ${ }^{5}$ The organisers encouraged an open debate by emphasizing that the school of thought to which a philosopher belonged was not to prevent his critics from taking his argument seriously. In terms of the calibre of scholars present from Germany, England, Italy and France, the event was a huge success. The congress attracted such eminent

\footnotetext{
${ }^{4}$ Eco, Umberto (1995). The Search for the Perfect Language. Oxford: Blackwell Publishers. p. 318

${ }^{5}$ Cited in, Canto-Sperber, Monique (2008). Moral Disquiet and Human Life. Princeton: Princeton University Press. p. 90.
} 
figures as Russell, Henri Bergson (1859-1941), Moritz Cantor (1829-1920), Henri Poincaré (1854-1912) and Paul Tannery (1843-1904). ${ }^{6}$

There was a brief discussion at the event about the problems caused by national language differences at international congresses. The sudden popularity of Esperanto had caught the attention of some of the participants of the congress, for it was during this discussion that the principle of an artificial international language as a possible solution was put forward. Couturat's involvement with international language began when he took it upon himself to investigate possibilities and the potential of such a language as a new lingua franca for the international philosophical community.

In 1900 Couturat had not yet published on the theme of international language. But by then he had not only proven himself as a talented mathematician and philosopher. He was also an excellent organizer, because Couturat was the initiator and organizer the First International Congress of Philosophy together with his close friend Xavier Léon (18681935), philosopher and director of the philosophical journal the Revue Métaphysique et de la Morale. Couturat had joined its editorial board in 1893, the year of its inception. In that same year he published a contribution to a heated debate between Poincaré, Russell and George le Challas on the principles of geometry. He also published a paper titled "L'évolutionnisme physique et le principe de la conservation de l'énergie" in which Couturat defended an opposing view to French philosopher Louis Weber. In 1895 he was appointed professor of philosophy in Toulouse, and in 1896, with the publication of his two doctoral theses, De L'inifini Mathématique and De Platonicis Mythis, he could claim to be both philosopher and mathematician.

Couturat's thesis De L'inifini Mathématique brought him in contact with the now famous British philosopher Bertrand Russell. Shortly after Russell reviewed it in Mind in 1897 Couturat sent him a letter of praise of the latter's recently published book Foundations of Geometry (1897). Russell wrote about this in his autobiography: "I had dreamt of receiving letters of praise from unknown foreigners, but this was the first time it had happened to me. He related how he had worked his way through my book 'armé d'un dictionnaire', for he knew no English". ${ }^{7}$

Couturat was an active popularizer of Russell's work on mathematics in France. In 1901 he had organized a French translation of his Essay on the Foundations of Geometry. And in 1905 he published a book titled Les Principes des Mathématiques, which was partially based on Russell's The Principles of Mathematics (1903). In turn, Russell was attracted to Couturat's work on the seventeenth century philosopher and mathematician Gottfried Leibniz (1646-1716), which Russell described as "His most valuable work". ${ }^{8}$ In 1901 Couturat published La Logique de Leibniz, a detailed study on Leibniz's work on logic. Three years later he published another large volume on Leibniz, titled Opuscules et

\footnotetext{
${ }^{6}$ Ibid. p. 90.

${ }^{7}$ Russell, Bertrand (1998[1951-1961, 3 vols.]). The Autobiography of Bertrand Russell. London/New York: Routledge. p. 135.

${ }^{8}$ Ibid. p. 136.
} 
Fragments Inédits de Leibniz, which contained many of the unpublished manuscripts he examined while he was working on La Loqigue.

From 1900 onwards Couturat's focus became increasingly centered on the project of international scientific language. A few months after the First Philosophical Congress, Couturat brought up the topic for the first time in his correspondence with Russell. His sudden passion for the international language must have been a surprise for Russell. Since the start of their correspondence in 1897 the topic had not surfaced. Couturat wrote that while he was not quite sure which of the existing international languages was suitable, he was highly in favour of the principle: "Je vous envoie des prospectus de l'Esperanto, pour que vous puissiez en juger par vous-même, et vous rendre compte de la possibilité et de l'utilité d'une telle langue. Bien entendu, je ne préconise pas tel ou tel système; c'est pour le principe que je prêche". ${ }^{9}$

At first Russell expressed an interest in Esperanto, but he soon changed his opinion about what at first probably seemed little more than impulsive project on Couturat's behalf. Russell claimed that most British scientists were too conservative to accept such a radical language project. He also made clear that he believed that there simply was no need to another language, because most scienists already knew French and English anyways: "On est beaucoup trop conservateur chez nous pour adopter une pareille reforme dans les publications. Du reste, la plupart de nos savants ont appris le français et l'allemand, et ne voient pas de nécessité pour une langue universelle". ${ }^{10}$

Over the following years Russell's scepticism towards the idea of an artificial international language turned into a tendency to mock the project, referring to Idists as "Idiots": "First there was Vollapük*, then Esperanto, then an improvement on Esperanto called Ido (its proficient are called Idiots) (...)". ${ }^{11}$ By then Russell had distanced himself from Couturat. In fact, they had no longer communicated with each other since 1907. In his autobiography Russell attributed this development to Couturat's involvement with international language: "In the last years I have lost contact with him because he became absorbed in the question of an international language". ${ }^{12}$ But Russell's rather unflattering portrait of Couturat on the same page suggests that personality differences between the two men had also driven them apart:

\footnotetext{
${ }^{9}$ Couturat, Louis (2001[1900]). 'Lettre de Couturat à Russell (05.11.1900),' in Schmid, Anne-Françoise (ed.), Correspondance sur la Philosophie, la Logique et la Politique. Paris: Editions Kimé. p. 204.

${ }^{10}$ Ibid. p. 210.

${ }^{11}$ Cited in, Urquhart, Alasdair (2002). 'The Couturat-Russell Correspondence [review of A.-F. Schmid (ed.), Bertrand Russell Correspondance sur la Philosophie, la Logique et la Politique avec Louis Couturat (18971913)],' Russell: the Journal of Bertrand Russell Studies (22)2: pp. 188-192. p. 193. *Note that Russell misspelled Volapük as "Vollapük".

${ }^{12}$ Russell (nr. 7), The Autobiography of Bertrand Russell, p. 135.
} 
I remember lunching with him in Paris in July 1900, when the heat was very oppressive. Mrs. Whitehead, who had a weak heart, fainted, and while gone to fetch the sal volatile somebody opened the window. When he returned, he firmly shut it again, saying: 'De l'air, oui, mais pas de courant.' I remember too his coming to see me in a hotel in Paris in 1905, while $\mathrm{Mr}$ Davies and his daughter Margaret (...) listened to his conversation. He talked without a moment's intermission for half an hour, and then remarked that 'the wise are those who hold their tongues'. At this point, $\mathrm{Mr}$ Davies, in spite of his eighty years rushed from the room, and I could just hear the sound of his laughter as he disappeared. ${ }^{13}$

Despite Russell's critical reaction to the idea of an international artificial language for science, Couturat continued to express his enthusiasm elsewhere for such a language with unabashed gusto: "Je vous remercie de vous intéresser à notre projet, et d'y être favorable: plus vos compatriotes paraissent devoir être réfractaires (au début du moins), plus il importe de faire de la propagande. Insistez surtout sur le caractère neutre et désintéressé de notre enterprise". ${ }^{14}$

Couturat also brought up the theme of international language during the Second International Mathematical Congress in Paris, which took place in the same week as the First International Philosophical Congress. Its proceedings reveal that while the issue of multiple languages was indeed discussed, Couturat's proposal to install an international language for science was received with great reservation by its participants. ${ }^{15}$ But again, this did not stop him to continue to pursue his dream. In a letter to his friend and colleague Xavier Léon, Couturat expressed his unwavering determination to further the cause of the international language in the face of a negative reception by his fellow scientists: "La décision du Congres de Mathématiciens contre la langue universelle n'empêchera ni Leau ni moi de travailler pour elle". ${ }^{16}$

As pointed out, in 1901 Couturat and the French mathematician Léopold Leau founded the DAIAL. Provided that the title of the delegation contains the word "adoption", and not "research" or "investigation", it is clear that from the outset Couturat was convinced of the necessity of an international language. In fact, we will see that what

\footnotetext{
13 Ibid. pp. 133-4.

${ }^{14}$ Couturat, Louis (2001[1901]). 'Lettre de Couturat à Russell (03.01.1901),' in Schmid, Anne-Françoise (ed.), Bertrand Russell Correspondence sur la Philosophie, la Logique et la Politique avec Louis Couturat, pp. 216219. Paris: Éditions Kimé. p. 217-218.

${ }^{15}$ (1902). Compte rendue du Deuxième Congrès Internationale des Mathématiciens. Tenu à Paris du 6 au 12 aout 1900. Paris: Gauthier-Villars, Imprimeur-Librairie. p. 23

${ }^{16}$ Letter by Couturat to Xavier Léon dated August $19^{\text {th }} 1900$. From the correspondence by Xavier Léon, Manuscrits de la bibliothèque Victor-Cousin.
} 
started as an informal task soon developed into a passionate quest to promote an international scientific language that overshadowed his other scientific interests.

\subsection{The return of Babel}

Why was Couturat convinced of the necessity of an international language? Couturat's first book on the subject of international languages, the monumental Histoire de la Langue Universelle (1903), which was written in collaboration with Leau, offers some answers. The book offered an extensive overview of past attempts to create a universal language, including those of such seventeenth century philosophers and intellectuals as Rene Descartes (1596-1650), George Dalgarno (1616-1687), Wilhelm Gottfried Leibniz, as well as more contemporary artificial language projects like Volapük and Esperanto. Its preface portrayed the early-twentieth-century scientific community as rapidly internationalising. But instead of facilitating a coherent and smooth interaction between scientists, the growing number of international scientific organisations often presented members with problems in communication owing to the diversity of their national languages.

To characterize this impeded flow of international communication caused by a confusion of national tongues, Couturat and Leau referred to the tower of Babel, stating that: "On a du Remarque que l'expression de tour de Babel se présente comme malgré lui a esprit de l'auteur et que la première condition de l'organisation du travail scientifique qu'il énonce est I'uniformité de la nomenclature, c'est à dire un vocabulaire international". ${ }^{17}$ Their statement was a response to a speech by the secretary of the mathematics section of the French Academy of Sciences, the mathematician Gaston Darboux (1842-1917), that was published two years earlier in Le Journal des Savants.

Darboux had called for the need for the International Association of Academies (IAA), which was established in 1899 , as a functional organ for an international organization and coordination of science in order to avoid what he referred to as a return of Babel. Darboux observed that: "It is impossible not to be struck by the speed at which international organizations multiply today". ${ }^{18}$ In his eyes "this tendency towards association" meant that the international scientific community itself was rapidly expanding. He claimed that unless the enormous scientific production in a multitude of languages was "unified and coordinated" there was a serious risk of a "return to the Tower of Babel". ${ }^{19}$

But while Darboux presented the establishment of the IAA as a functional organ to bridge national differences in the scientific community, Couturat and Leau viewed its establishment as only the first important step towards a proper organization of the international scientific community. In their eyes the means of intellectual communication

\footnotetext{
${ }^{17}$ Couturat, Louis \& Leau, Leopold (1903). Histoire de la Langue Universelle. Paris: Librairie Hachette. p. 9.

${ }^{18}$ Darboux, Gaston (1901). 'L'Association Internationale des Académies,' Le Journal des Savants: 5-23. p. 6.

${ }^{19}$ Ibid. p. 11.
} 
had not progressed at an equal pace with man's capacity to communicate and travel across the boundaries of nations. They reasoned that "A quoi bon pouvoir se transporter en quelques heures dans un pays étranger, si l'on peut ni comprendre les habitants ni se faire comprendre entre eux?". ${ }^{20}$ So they claimed the next step was the adoption of an international language to build a bridge between the advances of intellectual communication on the one hand, and the rapid increase of the means to communicate on the other.

What kind of language did they envision? Couturat and Leau judged Latin's grammar to be too complex and irregular, and the ideography of philosophical languages, which are languages constructed from first principles like logical languages, to be "as complicated as Chinese vernacular". ${ }^{21}$ They claimed that the creation of an artificial language was the best option for transcending the linguistic confusions, or the Babel of many tongues, now characterising contemporary science. But this did not imply the creation of "a language that Adam could, or should, have invented". ${ }^{22}$ Instead of creating a language from scratch, they suggested that its basic building blocks should be words drawn from existing national languages. Esperanto was a product of French, Italian and some Slavic elements. The constructed nature of Esperanto was appealing to Couturat. He and Leau praised it as possessing a system of word formation "d'une régularité et fécondité admirables." ${ }^{23}$

By 1905 Couturat became increasingly convinced of Esperanto's imperfections. In addition to viewing its inclusion of Slavic elements as problematic, he held that Esperanto lacked the precision and neutrality that was required for the smooth transfer of scientific knowledge. He claimed that the fundament for the construction of a better version of Esperanto was already present in the form of science's vocabulary and the vocabularies of existing national languages, pointing out that scientific terms were generally the same internationally. Couturat also pointed out that many regular words were the same in different European languages. He claimed that for this reason it was only natural to argue that all these words, which he continuously referred to as possessing "la plus grande internationalité", were to be used as building blocks for a perfect international language.

\footnotetext{
20 Ibid.

${ }^{21}$ Couturat, Louis (1906). Pour la Langue Internationale. Coulommiers: Imprimerie Paul Brodard. p. 14. [My translation]

22 Ibid. p. 15. [My translation]

${ }^{23}$ Couturat \& Leau (n. 17), Histoire de la Langue Universelle, p. 340.
} 


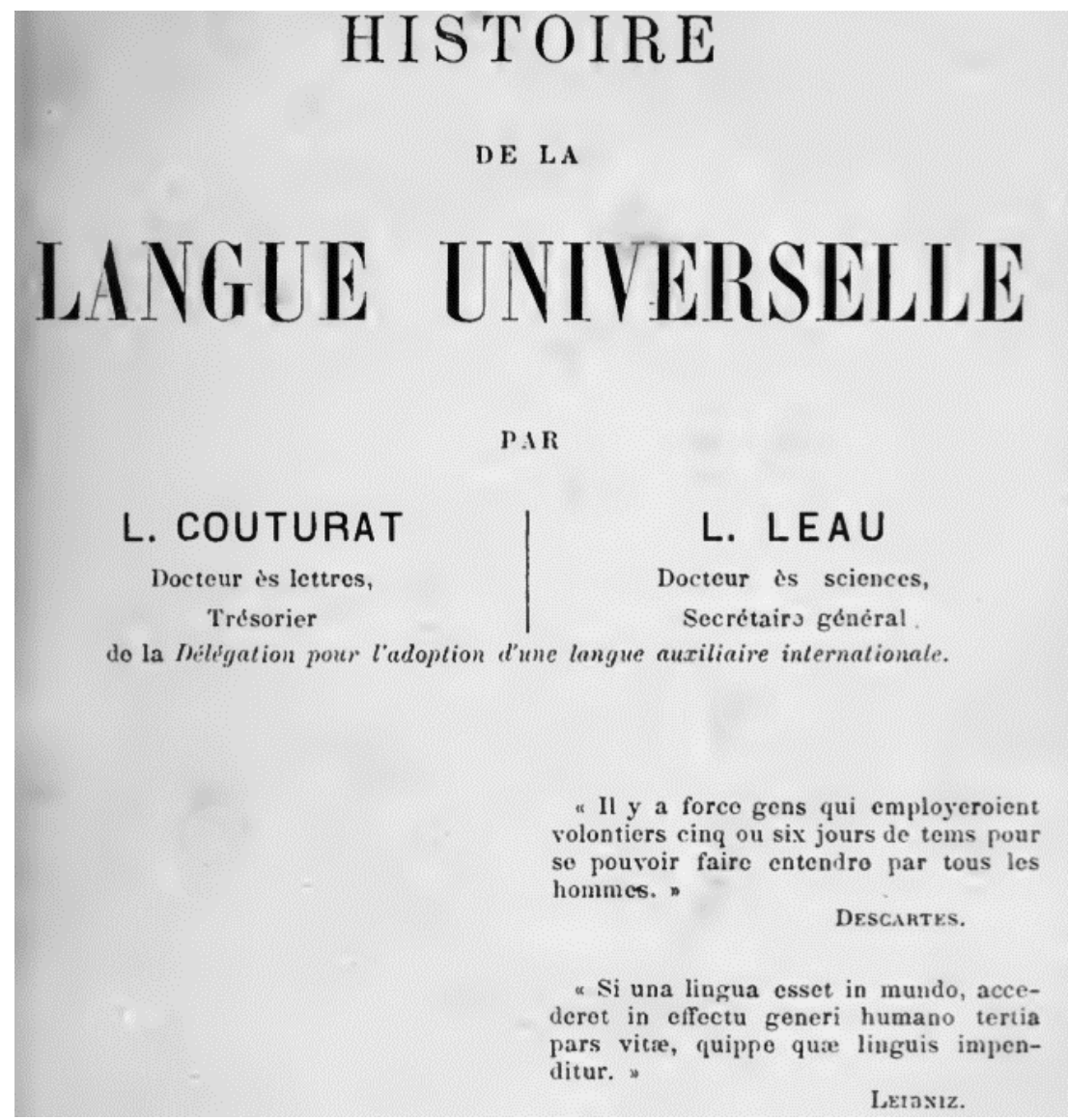

The cover of Couturat's and Leau's Histoire de la Langue Universelle with quotes by Descartes and Leibniz pertaining to the topic of universal language.

\subsection{Building a scientific language}

In 1906 Couturat began to work on the creation of Ido in collaboration with Marquis Louis de Beaufront (1855-1935), a French Esperantist. De Beaufront played a major role in the promotion of Esperanto in France. From 1900 onwards he and Couturat had been corresponding extensively about matters relating to the ideal of an international language. ${ }^{24}$ In 1898 he founded the Société Pour la Propagation de l'Espéranto, and a new journal called L'Espérantiste. ${ }^{25}$ But by 1906 he too believed that Esperanto suffered from imperfections. In that same year Couturat pointed at the need for a scientific selection of the most components of the international language by special commissions who were assigned the task of deciding upon the appropriate term and of fixing its exact meaning. In 1906 the DAIAL made a formal request to the IAA in Vienna to select an international language, this was turned down.

\footnotetext{
${ }^{24}$ Unfortunately this correspondence no longer exists. According to Claude Gacond, curator of the Swiss Centre de Documentation et d'Etude sur la Langue Internationale, de Beaufront lost his entire correspondence - and his house - in a fire.

${ }^{25}$ Forster, Peter G. (1982). The Esperanto Movement. The Hague: Mouton Publishers. p. 76.
} 
Undeterred by another clear sign of a general disinterest in his project from his scientific colleagues, Couturat took matters in own hands in 1907 by organizing a series of meetings for the delegates of the DAIAL. The aim of these meetings was to identify the best option from existing artificial language projects. As the delegation's president, Couturat upheld its image of disinterestedness by concealing his role as the creator of Ido. The meetings took place in Paris at the Collège de France from 15 until 24 October. During each session an international language project was presented and then discussed by a committee consisting of twelve to fifteen representatives of other international language projects. Several language authors appeared before the committee. Esperanto was one of the languages discussed and unaware of his involvement with Ido, the inventor of Esperanto, Zamenhof, sent de Beaufront as its advocate. It was not the first act of deceit de Beaufront committed in his life. He claimed to be a descendent of the French king who had been forced to work as a private tutor after losing his fortune. But there was never any proof that this was true. ${ }^{26}$

The committee emphasized several of Esperanto's weak points. Its use of diacritical marks (acute, grave and cedilla) was criticized as inefficient for writing and as causing too many printing problems. Its a priori components, meaning artificially contructed words, were criticized as being unnecessarily complicated. These included Kie (where), Kial (why), Kiam (when), Kiel (how). Despite these criticisms the committee selected Esperanto as the best option then available because of its relative perfection and the numerous and varied uses it had already attracted. But the committee did not recommend its adoption without modifications. These were to be devised by a permanent commission in collaboration with the Ido project, which Couturat had anonymously submitted to the members of the Committee.

When Couturat turned out to be one of its most militant defenders, it became clear that he was Ido's main author. Not surprisingly, the Esperantists felt betrayed. ${ }^{27}$ Consequently, after 1907 the story of his efforts for the international adoption of Ido was one of a constant battle with defenders of Esperanto. His apparent 'neutral' meetings in Paris in 1907 to select an international language were little more than a ruse to promote Ido.

Ido used the 26-letter Latin alphabet as opposed to the Esperanto's use of $\hat{c}, \hat{g}, \hat{h}, \hat{\jmath}, \hat{s}$ and $\breve{u}$ instead of the letters $q, w, x$ and $y$. But Ido was meant as much more than a simplification of the alphabet. In his reexamination of Esperanto together with de Beaufront, Couturat applied a scientific methodology to make it more regular and more neutral. Ido was to be constructed according to precise and rigorous rules that left no room for uncertainty and ambivalence. The end result, what he saw as Ido's simplicity and precision, was to be nothing less than an expression of logical objectivity of science itself: “Cela revient à dire que le choix de la L.I. n'a rien arbitraire, mais dépend de la science elle-

\footnotetext{
${ }^{26}$ Ibid. p. 75.

${ }^{27}$ Ibid. p. 123.
} 
même. Or, l'Esperanto tourne le dos à l'internationalité déjà acquisse, tandis que Ido s'y conforme et se prête à tous ses développements ultérieurs." ${ }^{28}$

Couturat's scientific method consisted of applying two basic logical rules in Ido's creation: the principle univocity and the principle of reversibility. Univocity is a term in logic to describe that which is expressed in one voice. The univocity principle demanded correspondence between sign (word) and signified (idea). Every notion was to be expressed by one word and one word only. Couturat believed that all languages evolved naturally towards an increasing degree of simplicity through "a reduction of the grammatical forms to their most general and essential forms," but he argued that the evolution in natural languages towards a univocal coupling of notion and word was "slow and often troubled". ${ }^{29}$ An artificial language could cut this evolution short by imposing the principle of univocity uniformly.

The reversibility rule required that if a root and affix were combined, the new word must represent the combined meaning of both root and affix. The idea was that by applying this rule, every derivation was reversible. If one passed from one word to another in the same family by adding or subtracting affixes, one was able to easily arrive at any word of that same family. From labor/ar, which meant to work, one could move to labor/ist, with the suffix "-ist" as the exclusive denomination for occupation or profession. And from labor/ist one could easily move to labor/ist/o, which meant worker. According to Couturat, following this principle meant that "(...) one can proceed from any word whatsoever of a family and arrive at any other word, in an absolutely unique manner, whereas if one did not observe this principle one would inevitably obtain two meanings for the same word". ${ }^{30}$

Couturat's application of such logical principles was not only meant to give Ido its cutting edge as a precise and efficient tool for carrying scientific knowledge across national boundaries. He also argued that its system of logical derivation meant that the roots of existing natural languages were chosen that were understood by a maximum number of Europeans. A brochure titled, Pour la Langue Auxiliaire Neutre (1906), claimed that Ido was "the only principle of justice and neutrality". ${ }^{31}$ Instead of pursuing what was referred to as the "chimerical" cause of national languages, it argued that not only scientists, but all Europeans should actively pursue the cause of Ido. ${ }^{32}$ He claimed that in addition to serving the scientific community, Ido was an efficient and neutral vehicle for anyone involved in the conduct of their international transactions and negotiations-politicians, traders, and even ordinary travelers.

\footnotetext{
${ }^{28}$ Couturat, Louis (1909). Le Choix d'une Langue Internationale. Paris: Éditions de la Revue du Mois. p. 12.

${ }^{29}$ Couturat, Louis (1911). 'Des Rapport de la Logique et de la Linguistique,' Revue de Métaphysique et de Morale (19)4: pp. 509-516. p. 512.

${ }^{30}$ Couturat (nr. 3), 'On the Application of Logic to an International Language', p. 42.

${ }^{31}$ Couturat (nr. 21). Pour la Langue Internationale, p. 5.

${ }^{32}$ Ibid.
} 


\subsection{Early-twentieth-century Babel as myth}

In the years after which the Committee had made its choice for Esperanto as the best of the international languages on the condition that it was to be simplified, Couturat worked hard to promote Ido. In addition to publishing various brochures and pamphlets on the matter, he published numerous articles on the application of logic to the international language in the Revue de Métaphysique et de la Morale. In 1908 he established a monthly journal called Progresso that was published in Ido. Progreso continues to be published today. Its front cover includes a tribute to its initiator Couturat in the form of a brief description. Couturat had created it, however, as a propaganda vehicle for Ido. In fact, until his death in 1914, Couturat was not only its main contributor. For he actually wrote the bulk of its articles en discussions. As to the size and consistency of the Ido community during this period, it is hard to say exactly how many Ido followers there were. It is thought, however, that from the much larger Esperanto community, about twenty percent of the Eseranto leaders defected to Ido, and about two to four percent of the ordinary Esperantists defected to Ido. ${ }^{33}$

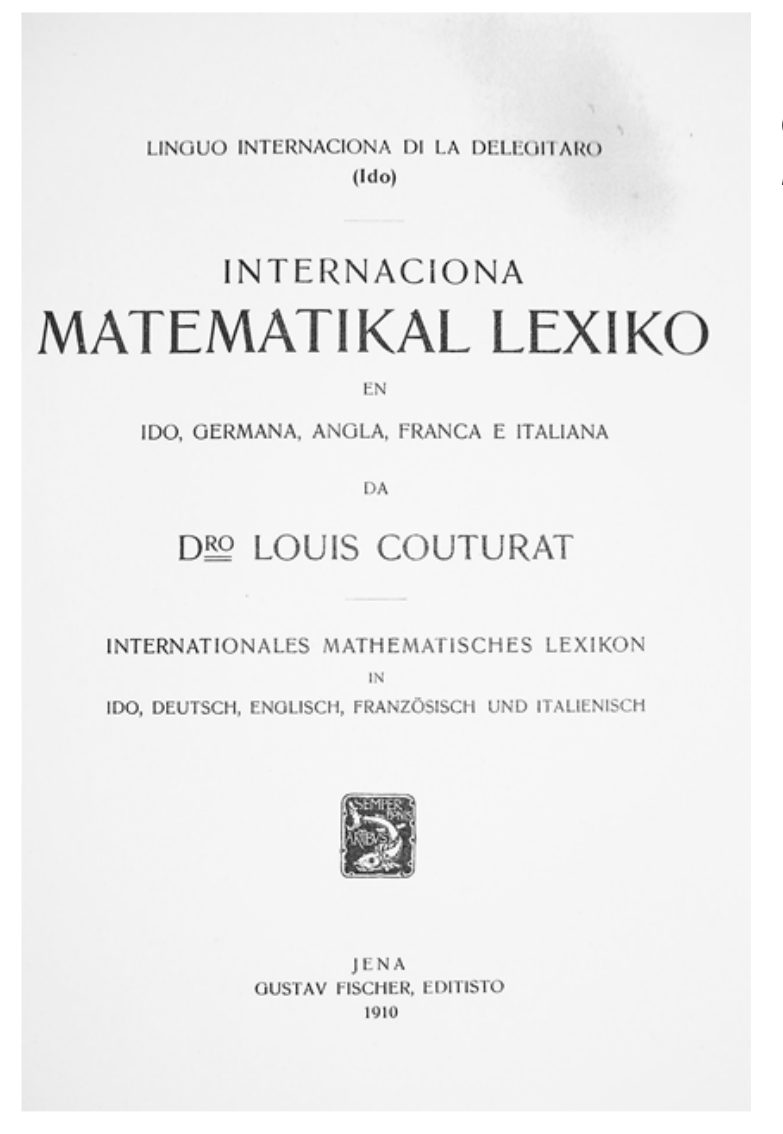

Couturat's mathematical lexicon in Ido, Internaciona Matematikal Lexiko.

\section{NTERNACIONA \\ MATEMATIKAL LEXIKO}

DO, GERMANA, ANGLA, FRANCA E ITALIANA

D苜 LOUIS COUTURAT

INTERNATIONALES MATHEMATISCHES LEXIKON

DO, DEUTSCH, ENOLISCH, FRANZÖSISCH UND ITALIENISCH

\footnotetext{
${ }^{33}$ Lapenna, Ivo \& Lins, Ulrich \& Carlevaro, Tazio (1977). Esperanto en perspektivo: faktoj kaj analizoj pri la internacia lingvo. London-Rotterdam: UES. p. 424.
} 


\section{INTERNACIONA MATEMATIKHL LEXIKO.}

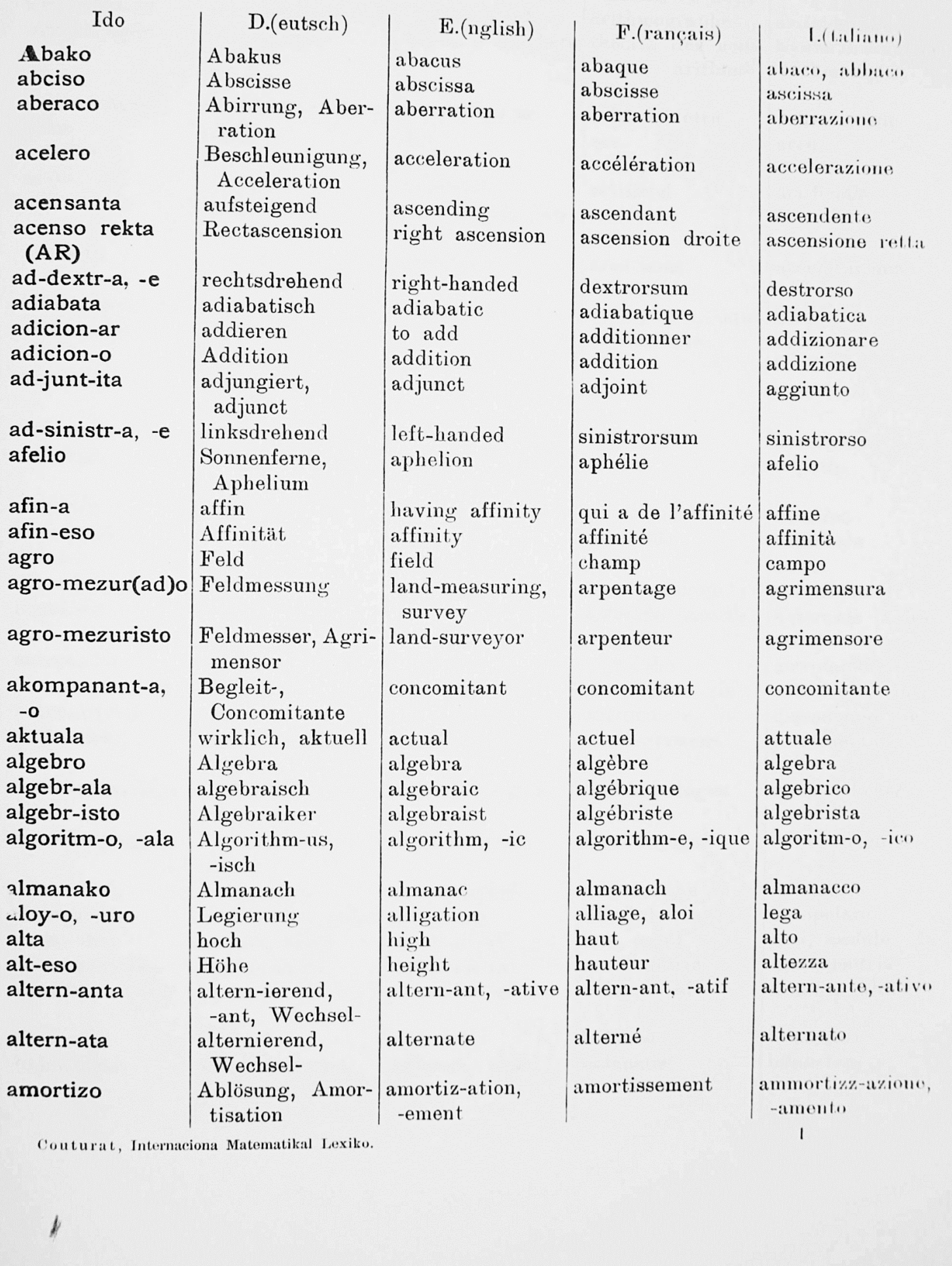



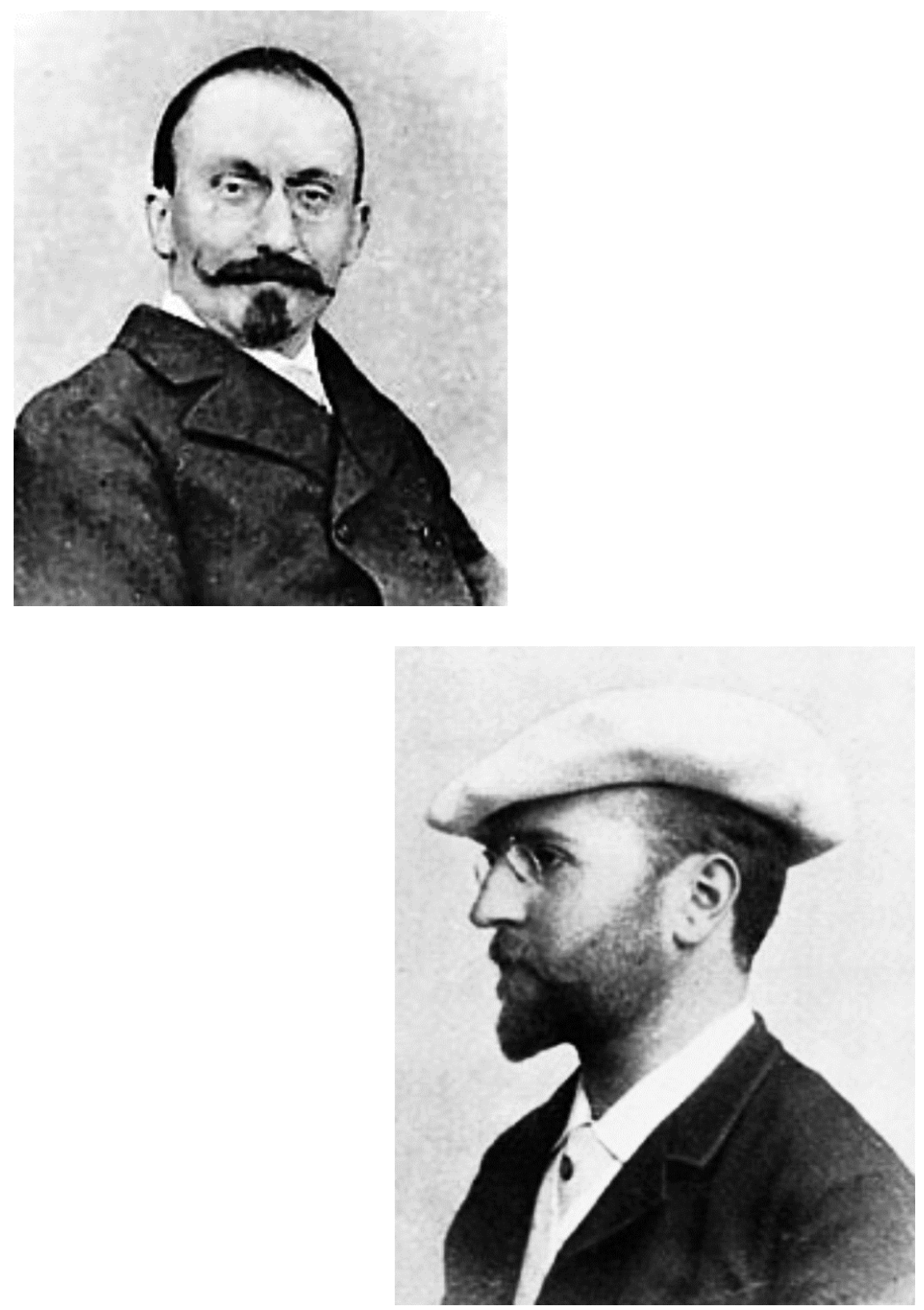

One of the few existing photographs of Louis Couturat (left), ${ }^{34}$ and a photograph of Ido's co-founder Louis de Beaufront. ${ }^{35}$

In 1910 Couturat published an extensive international mathematical lexicon in Ido titled Internaciona Matematikal Lexiko ${ }^{36}$ with German, English, French and Italian translations. He also composed three large dictionaries together with de Beaufront: French-Ido, EnglishIdo and German-Ido. The first was published, the second was printed but never published,

\footnotetext{
${ }^{34}$ Retrieved from the Worldwide Web November $20^{\text {th }}, 2012$ : http://www.aleph.com.br/kce/historio-12beaufront.htm

${ }^{35}$ Retrieved from the Worldwide Web October $20^{\text {th }}, 2012$ :

http://www.librarything.com/author/beaufrontlouisde

${ }^{36}$ Couturat, Louis (1910). Internaciona Matematikal Lexiko. Jena: Gustav Fischer Editisto.
} 
and the third was never completed. Couturat's last publication was an article on the current status of French logic for an Encyclopédie Internationale des Sciences Philosophiques in French, English and German. The German edition was published in 1912, and the English in 1913. But Couturat did not live to witness the publication of the French edition. On August the $3^{\text {rd }}$ in 1914, the second day of the French mobilization for World War I, Couturat was killed in a car accident on his way from Paris to Fontainebleau. Couturat's death was a blow to the Ido movement in France. Despite constant efforts to mobilize support by producing a waterfall of pamphlets, publications and dictionaries, he had waged a lonely war against what he believed to be the early-twentieth-century confusion of many tongues.

But while Couturat failed to gain wider support for Ido, some of his contemporaries appeared to share his conviction that the increasing diversity of national languages at international congresses and other events was becoming problematic. He presented international language as a scientific solution to a worrying discrepancy. On the one hand the technical ability to communicate and travel across national borders progressed rapidly. On the other hand the linguistic means of international intellectual communication developed only slowly and inefficiently. With the emergence of a rapidly expanding international community since the second half of the nineteenth century, at the brink of the twentieth century, universal exhibitions, international conferences and organizations had become regular events. Consequently, the issue of multiple national languages, which was magnified by a rise of national languages in the scientific community since the second half of the nineteenth century, was discussed on several occasions towards the end of the century.

As such, the general context appears to provide a clear argument for Couturat's propagation of an international language as an attempt to upgrade the communication of knowledge to the demands of what was perceived to be a growing international scientific community. In fact, the problem of multiple languages in an expanding international scientific community was frequently discussed towards the end of the nineteenth century. Propelled by a rapid increase of transnational mobility and communication, universal exhibitions, international conferences and organizations were becoming regular events during this period. With the first Universal exhibition in London in 1851, which provided a platform for nations to showcase its innovations, from 1867 onwards they became regular events when Paris organized one at eleven-year intervals. Moreover, between 1850 and 1910, with a steep rise between 1900 and 1910, 382 international organizations were established. ${ }^{37}$ On these occasions, its participants were confronted with a multitude of nationalities, offering a rich palette of cultures to compare and contrast. During his visit to the first universal exhibition in 1851 in London, the German architect Gottfried Semper (1803-1879) was so overwhelmed by the amount of cultures and spoken languages

\footnotetext{
${ }^{37}$ Speeckaert, Georges Patrick (1957). The 1,978 organizations founded since the congress of Vienna: Chronological list. Brussels: Union of International Organisation. p. 25.
} 
exhibited at the fair that he called the Crystal Palace a modern tower of Babel. ${ }^{38}$

In congruence with the expansion of the international community, the scientific community also underwent a radical internationalization, replacing the older cosmopolitan image of the Republic of Letters with the emblem of an international scientific community. Between 1860 and 1904, 28 international organizations were established in the field of the pure sciences. ${ }^{39}$ International cooperation between scientists was not new, ${ }^{40}$ but Martin Geyer and Johannes Paulmann point out that what was new from the nineteenth century onwards was that such initiatives were consciously referred to as "international". ${ }^{41}$ The earliest initiatives in the scientific community that brought together scientists from different nations under this banner occurred in the 1820s and 1830s when the first official international congresses were organized to establish international standards for, for instance, botanical nomenclature. ${ }^{42}$

But international scientific organizations and congresses became a common occurrence from 1865 onwards. From that year international congresses of astronomy were held on a regular basis. In 1875 an international treaty known as Metre Convention was signed by 17 states, which established that the Comité international des poids et mesures and the Bureau international des poids et mesures were to cooperate internationally to establish and agree upon a standardized system for measurements. In 1899 the Royal Society undertook the first attempt at a scientific bibliography Royal Society by establishing the International Catalogue of Scientific Literature. In that same year the earlier mentioned IAA was born, an association of the larger learned societies of the western world that aimed "to promote and make preliminary preparations for work requiring international cooperation for its prosecution" as well as "to facilitate intercourse, both professional and social, between scientific men of all countries" ${ }^{43}$

We saw that Gaston Darboux shared Couturat's concerns in 1901 about the need for a proper international organization and coordination of science in order to avoid a return of Babel when he praised the IAA. There are numerous sources from that period that give their dramatic depiction of the international state affairs in the scientific community some credence. The establishment of international organizations went hand in hand with

\footnotetext{
${ }^{38}$ Semper, Gottfried (1966[1852]). 'Wissenschaft, Industrie und Kunst', in: Hans M. Wingler (ed.), Wissenschaft, Industrie und Kunst, und andere Schriften über Architektur, Kunsthandwerk und Kunstunterricht. Mainz/Berlin: Kupferberg. p. 28.

${ }^{39}$ Speeckaert (nr. 36), The 1,978 organisations founded since the congress of Vienna: Chronological list, p. Xiii.

${ }^{40}$ Rozwadowski, Helen M. (2002). The Sea Knows No Boundaries: A Century of Marine Sciences Under Ices. Washington: University of Washington Press. p. 13.

${ }^{41}$ Geyer, Martin H. \& Paulmann, Johannes (2001).'Introduction: The Mechanics of Internationalism,' in Geyer, Martin H. \& Paulmann, Johannes (eds.), The Mechanics of Internationalism, pp. 1-27. Oxford: Oxford University Press. p. 2.

${ }^{42}$ Rozwadowski (nr. 40), The Sea Knows No Boundaries: A Century of Marine Sciences Under Ices, p. 14.

${ }^{43}$ (1900). 'The International Association of Scientific Societies', Science (11)365: p. 124-125. For a history of the IAA, see, Schroeder-Gudehus, Brigitte (1990) 'Les congrès scientififiques et la politique de coopération internationale des académies de sciences,' Relations Internationales (62): pp. 135-48.
} 
inevitable confrontations between differing mother tongues. Like Gottfried Semper at the Crystal Palace in 1851, scientists were confronted with a multitude of languages at international scientific conferences. But unlike Semper, who like many curious visitors visited the 1851 London fair to be entertained, a clear and efficient communication was essential for scientists involved in organising and participating in international scientific conferences.

Diary accounts by the German astronomer Wilhelm Foerster (1832-1921) on the Meter Conference of 1872 in Paris offer a lively account of the excitement, and especially of the difficulty of negotiating the terms for an international measurement system in a foreign language. Geodecists at the International Conference on Geodesy in 1867 called for establishing a new, international prototype metre. New and more accurate measurements of arcs of meridians were reported at the conference, leading to new computations of the shape of the earth, and therefore also of the length of the quadrant. ${ }^{44}$ These changes affected the length of the metre, which led to questions about the standard of the metre. In reaction to calls for the need of defining a new, internationalized standard for the metre, the French government organized the international Meter Conference in 1872. Among the scientific representatives from 26 countries present at the event, Foerster represented the German interests.

In his diary Foerster expressed his excitement about meeting the director of the Parisian observatory, Charles-Eugène Delauney (1816-1872). Foerster's first words on Delauney were dedicated to a description of his appearance. He expressed a sense of amazement about finally seeing the face of a man with whom he has corresponded for several years to organize an event that had been postponed due to the Franco-Prussian war of 1871. He noted that Delauney had one of the most "Liebeswurdigsten Gesichter", and he added: "Fast hat er doch in Auge und Mond eine unbeschreibliche Offenheit und Delikatesse, und sein Französisch ist wahre Musik". ${ }^{45}$ Several sentences later, however, Foerster's enthusiasm made way for a more sobering comment on the difficulty of contributing to the discussion in French during his first official meeting in Paris. He wrote: "In der Debatte habe ich mich heut noch vollständig zurückgehalten. Ich muss Ohr und Zunge noch mehr an die Sprache gewöhnen, bevor ich tätig mit eingreife. Eine kleine Mitteilung habe ich heute gebeten, vorlegen zu dürfen. Sie wurde freundlich angehört" ${ }^{46}$

German scientists had been accustomed to communicate in French, more so than the French were accustomed to communicate in German. During the eighteenth century, German culture (especially in Prussia) was strongly influenced by France. Consequently,

\footnotetext{
${ }^{44}$ In 1791 the French Academy of Sciences selected a a meridional definition of the metre. It stated that the metre was as one ten-millionth of the length of the earth's meridian along a quadrant, which is the distance from the Equator to the North Pole.

${ }^{45}$ Foerster, Wilhelm (1977[1873-75]) in Wattenberg, Dieter (ed.), Wilhelm Foerster in seinen Tagebuchblattern über die Meter-Konferenzen in Paris. Wiesbaden: Franz Steiner Verlag. p. 263.

${ }^{46}$ Ibid, p. 263.
} 
French was the spoken language at German royal courts. ${ }^{47}$ In that respect Foerster's case illustrates the difficulty but not the impossibility of international communication between scientists, because he was able to speak French. But towards the end of the nineteenth century scientists were increasingly confronted with languages they never learned to speak or read. During the second half of the nineteenth century the number of national languages strongly increased as European nations aspired to have their own national language.

Anne Rasmussen shows that while in 1800 science was published in ten languages (English, German, French, Italian, Spanish, Swedish, Danish, Polish, Russian, Greek), by 1900 science was published in more than 20 languages, including Portuguese, Romanian, Czech, Serbo-Croatian, Slovenian, Bulgarian, Magyar, Finnish, Lithuanian, Latvian, Dutch, Norwegian (two types), Icelandic, Catalan, Irish, Turkish, Albanian and Basque. ${ }^{48}$ Faced with language diversity in a rapidly expanding international scientific community, difficult and inefficient questions of translation were becoming a frequent experience for scientists partaking in international affairs. In the same article, Rasmussen situates Couturat's promotion of Ido at the intersection of the increasing number of international organizations, and the publication of science in an increasing number of international languages. In view of these developments, it is not surprising that members of the scientific community discussed and considered the adoption of an international language to streamline communication in journals and at congresses.

In 1889, for instance the American Philosophical Society to adopt Volapük as a possible language for international communication: "An artificial language of such kind would indeed be of great benefit for scientists, and make many publications, such as Hungarian, Bohemian, Romanian, etc. available". ${ }^{49}$ Others considered a return of Latin as a solution. Françoise Waquet points out that those who were in its favor believed that "the elegance of Latin, its literature and tradition, gave it superior claims".$^{50}$ The Englishman George J. Henderson (?-1911) made a serious attempt to revive Latin as an international language for commerce and science. Via an institution called Societas Internationalis Modernae he received support from several renowned French scholars, including economist Paul Leroy-Beaulieu (1843-1916), historian Maurice Prou (1861-1930), Latinist Louis Havet (1849-1925), and archeologist and art historian Léon-Maxime Collignon (18491917). In Germany, Hermann Alexander Diels (1848-1922), a renowned philologist and member of the Berlin Academy of Science, was also an avid supporter of Latin. In his eyes, Latin enabled scientists to communicate neutrally on an international level. Together with

\footnotetext{
${ }^{47}$ Ager, Dennis A. (1998). Language Policy in Britain and France: The Processes of Policy. London/New York: Continuum International Publishing Group. p. 41.

${ }^{48}$ Rasmussen, Anne (1996). 'À la Recherche d'une Langue Internationale de la Science,' in Chartier, Rogier \& Corsi, Pietro (eds.), Sciences et Langues en Europe, pp. 139-155. Paris: École des Études en Sciences Sociales. p. 142.

${ }^{49}$ (1889). 'International Language (Editorial),' Science 13(310): p. 25.

${ }^{50}$ Waquet, Françoise. (2001). Latin or the Empire of a Sign: From the Sixteenth to the Twentieth Centuries. London/New York: Verso. p. 264.
} 
German historian Theodor Mommsen (1817-1903), and the Austrian geologists Eduard Suess (1831-1914), Diels prepared a Thesaurus lingue latine to promote it as such. In 1900 Diels also supported the establishment of popular Latin language courses in Berlin.

So Couturat's effort was one of several answers to the turn-of-the-century developments of a rapidly expanding international scientific community on the one hand, and the upsurge of national languages on the other. Like most of those who claimed that the resulting language multiplicity in the scientific community could be overcome through the adoption of a single language, Coururat experienced its difficulties at first hand.

By 1900 his scientific activities brought him in the midst of the late- nineteenth- and early-twentieth-century international scientific community. By then Couturat had helped the Revue Métaphysique et de la Morale become a leading journal for the philosophy of mathematics through his activities as its co-editor and contributor. The French historian Stephan Soulié points out that the establishment of the RMM was a crucial step in the organization of the French philosophical community. Its hosting the First International Philosophical Congress in 1901, and one year later its role in founding the French Philosophical Society, contributed greatly to this development. ${ }^{51}$ The social networks opened up by the establishment of the $R M M$ - both on a national and international level , and the intellectual ideas that were discussed and galvanized in its monthly editions, are closely entangled with Couturat's rise as a philosopher and mathematician. These provided him the practical means to present as well as publish his ideas and to meet other scientists at an international level.

There are no direct accounts of Couturat's first hand experiences with national language differences at the congresses, but several letters to his colleague Xavier Léon reveal that Couturat was burdened with the translation of papers that were presented at the Philosophical congress. ${ }^{52}$ The papers were written in highly formalized and technical idiom of English, French, German and Italian. This experience surely played a role in pushing him to propagate international language to bypass the tediousness of translating scientific texts.

Couturat was also involved in compiling and publishing an extensive encyclopaedic lexicon for philosophy called Vocabulaire technique et critique de la philosophie. He compiled it in collaboration with Léon and another friend and colleague, the French philosopher André Lalande (1867-1963). It was published in several parts between 1902 and 1923 in the Bulletin de la Société française de Philosophie. In 1926 their philosophical lexicon appeared for the first time in book form, and in 1976 its twelfth edition was published. Each entry presented different definitions that were sometimes accompanied by critical comments at the bottom of the page. The dictionary was intended for an

\footnotetext{
${ }^{51}$ Soulié, Stephan (2009). Les Philosophes en République: L'aventure Intellectuelle de la Revue Métaphysique et de la Morale et de la Société Française de Philosophie (1819-19140). Rennes: Presses Universitaires de Rennes.

52 Letter by Couturat to Xavier Léon dated September $25^{\text {th }} 1900$. From the correspondence by Xavier Léon, Manuscrits de la bibliothèque Victor-Cousin.
} 
international audience. Besides Greek and Latin, most entries included German, English and Italian translations. Couturat and Lalande wrote the entries under the letters $A$ and $B$. Under Couturat's influence Ido root words of entries were included where possible. ${ }^{53}$

But despite minor applications of Ido such as its inclusion in the Vocabulaire technique et critique de la philosophie, the majority of Couturat's colleagues simply did not share his dream. We did see that there was some interest in the principle of an international artificial language. But it is one thing to express an interest in the principles of an international scientific language, and another to dedicate the rest of one's career to its creation and promotion. On the whole scientists either simply did not see the problem of multiple national languages in the international scientists community. And more often than not, scientists were passionate supporters of their own national tongue as the best international language. An editorial in Science, for instance, was pessimistic about the prospect of an artificial language as international standard for this reason. It concluded that the tendency among scientists to cling to their national mother tongue made a broader acceptance of an international language unlikely:

There seems little hope that in this period of nationalism the majority of scientists will forego that their language is the language of the most accomplished and most cultured people of the world, and that it has a right to become one of the "world-languages". When this period has passed, English, French and German will continue to be better means of international intercourse than any artificial language. ${ }^{54}$

This view was representative of a general reluctance among turn-of-the-century scientists to support the adoption of an international artificial language. This trend was especially common among English, French, and German scientists. These languages represented the dominant vernaculars in the early-twentieth-century international scientific arena, so most international congresses were held in those languages. In fact, it was common for scientists to refuse any world language except their mother tongue because of the intimate relationship between language and nationality from the second half of the nineteenth century onwards. We saw that Bertrand Russell presented yet another perspective on international language matters. In a letter to Couturat he pointed out that he did not see the necessity of learning an additional language when the majority of British scholars already knew French and German. Couturat's project was received with similar reserve at the Second International Mathematical Congress in Paris in 1900. And we also saw that

\footnotetext{
${ }^{53}$ Schmitz, Walter H. (1985). 'Andre Lalande and the Terminology Critical Movement in France,' in Welby, Lady Victoria \& Schmitz, Walter H. (ed.), Significs and Language: The Articulate Form of Our Expressive and Interpretive Sources, pp. cxi-cxviii. Amsterdam: John Benjamins Publishing. p. cxv.

${ }^{54}$ (nr. 49), 'International Language (Editorial),' p. 25.
} 
even the IASA declined to support Couturat's formal request to appoint a committee to select an international language.

In other words, it appears that Couturat's promotion of Ido was not driven by a strong external demand for it. Some shared his perception of a potential turn-of-thecentury Babel in the international scientific community. But the reality of this image is questionable in view of the general reluctance among scientists to support his diagnosis of the problem and its solution by Ido. In what follows, it will be argued that an individual ideological program that consisted of several components drove Couturat's promotion of Ido.

\subsection{Logic as objectivity machine}

Couturat's belief in the precision and neutrality of Ido was a product of a distinctly late nineteenth-century conception of logic as a tool to construct a universal system of communication. His defence of symbolic logic placed him in the company of Charles Sanders Peirce (1839-1914), Alfred North Whitehead (1861-1947), Gottlob Frege (18481925), Bertrand Russell and the Italian logician Giuseppe Peano (1858-1932). They all operated in a branch of mathematics that made use of symbols to express logical ideas in order to create a sign system that communicated concepts properly and clearly. Frege's Begriffschrift (1879) was an early product of this field of logic that was inspired by Leibniz'

logic. The book proposed a Formel Sprache that was meant to free logic and arithmetic from the inconsistencies and deceptions of ordinary language and human intuition.

Lorraine Daston and Peter Galison frame attempts like Frege's Formel Sprache as expressions of a distinct turn-of-the-century notion of scientific objectivity they call "structural objectivity". Logicians, philosophers, mathematicians as well as physicists defended structural objectivity as overcoming the deficiencies of an older conception of objectivity that Daston and Galison call "mechanical objectivity". The arrival of the photograph in the nineteenth century made possible a new kind of scientific image that recorded specimens exactly and without human intervention. This development went hand-in-hand with the emergence of the ideal of mechanical objectivity: the scientist was supposed to be a self-effacing, machinelike recorder of idiosyncratic details. But by the end of the nineteenth-century mechanical objectivity was increasingly questioned as it became clear that the individual traits of the scientific observer could not be eliminated from his or her observations. Structural objectivity emerged out of logic, mathematics, physics, and philosophy. Rather than relying on detailed representations of nature through images and language, scientists now sought objectivity in structures of logical relationships, law-like 
sequences and mathematical logic that would make "science communicable among all subjects, everywhere and always". ${ }^{5}$

Couturat's promotion of logic as a means to by-pass the subjectivity of the human mind and language was a typical product of this trend. He stressed that in its pure form, logical reasoning was universal since men's capacity to reason logically was timeless and of all cultures. People were not only capable of understanding one another because they formed similar ideas; they related and constructed ideas in a similar manner. He was convinced that logical reasoning preceded sociology, psychology, and, of course, ordinary languages, which Couturat viewed as "imperfect and crude instruments". ${ }^{56}$ He claimed that logic was a superior tool by virtue of its pristine universalism. He criticized any attempt to apply psychology and sociology to logic, arguing that the first reduced logic to a psychology of intelligence, and the second to a social science. He even argued that reality was reduced to little more than subjective belief when psychology and sociology were pushed to their extremes.

Couturat argued that such a method was the very negation of reality, leading one to erroneously believe that what is called "La Logique" and "La Morale" is simply "une logique" and "une morale" that stood merely in a relative relationship to all forms of logic and morality in different times and societies. In Couturat's eyes "la vérité profonde éternelle" was not that man is reasonable because he is a social animal. He claimed that man is a social animal because he was endowed with reason in the first place: "On a beau seriner des mots à un enfant: il n'acquérait jamais les idées correspondantes, non plus qu'un perroquet, s'il n'était capable de les construire lui-même, de les créer en lui et par lui (...) ${ }^{\prime \prime}{ }^{57}$ By virtue of an inherent capacity to reason logically, we relate and construct ideas in a similar manner. This assumption made the idea of using logic to generate an external and objective structure to communicate ideas precisely and efficiently an obvious move.

Couturat found an example of how this could be done during his exploration of Leibniz's work on logic in the Leibniz Nachlass in Hannover. Leibniz passed away in the same city in 1706, but his unpublished work was catalogued only in 1895. According to Bertrand Russell all the work Leibniz did on logic during his lifetime was never published because it consisted of working drafts: "Leibniz wished to be thought well of, so he published only his second-rate work. All the best work remained in manuscript" ${ }^{58}$ Russell also pointed out that Couturat was "the first man who unearthed it". ${ }^{59}$ It was during this process of "unearthing" of Leibniz's work that Couturat became fascinated by the former's attempt to create a universal symbolic language, or a 'characteristica universalis'.

\footnotetext{
${ }^{55}$ Daston, Lorraine \& Galison, Peter (2007). Objectivity. New York: Zone Books. p. 255.

${ }^{56}$ Couturat, Louis (1905). 'Lecture inaugural, Collège de France,' in L'Oeuvre de Louis Couturat: de Leibniz a Russell, pp. 17-33. Paris: Presses de l'École Normale Supérieure. Proceedings of a conference. p. 24.

${ }^{57}$ Ibid, p. 23-24.

${ }^{58}$ Russell (nr. 7), The Autobiography of Bertrand Russell, p. 136.

59 Ibid.
} 
In La Logique de Leibniz Couturat explained that Leibniz' goal was to compose an alphabet of human thought that was supposed to express mathematical and metaphysical concepts, and that its symbols were based on Chinese symbols. Couturat was more than fascinated by Leibniz's project, in that he viewed it as a model for his own langauge project. In the same book he described the characteristica universalis as "un système des signes qui représentent immédiatement les choses (ou plutôt les idées) et non les mots, de manière que chaque peuple peut les lire et les traduire dans sa langue" ${ }^{60}$

In Histoire de la Langue Universelle Couturat and Leau even introduced Leibniz as the next important step in the evolution of universal languages, leaving behind similar attempts in the same period by the Scottish intellectual George Dalgarno (1616-1687) and the British natural philosopher John Wilkins (1614-1662). They argued that in contrast to the projects of Dalgarno and Wilkins, Leibniz's universal characteristic was much more than a means to express ideas internationally, because it was based on logic. Therefore, reasoning itself was rendered more logical and precise, or to use Couturat's description, more natural. He points out that Leibniz's project was: “(...) la vraie "Caractéristique réelle ", qui traduirait la composition des concepts pour la combinaison des signes qui représentent leurs éléments simples, de sorte que la correspondance entre les idées composées et leurs symboles serait naturelle, et non plus conventionnelle." ${ }^{61}$ So what made Leibniz's project interesting for Couturat was that it consisted of matching language with reason by equating it with mathematics.

By the time of his work on Leibniz's logic Couturat already declared his interest in the principle of an international language. The two projects fused when he viewed in Leibniz' work an original and systematic solution to the problem of multiple languages. In his eyes Leibniz' logic was a perfect synthesis between reason and language: "La philosophie de Leibniz apparait ainsi comme l'expression la plus complète et la plus systématique du rationalisme intellectualiste: il y a un accord parfait entre la pensée et les choses, entre la nature et l'esprit; la réalité est complètement pénétrée de raison". ${ }^{62}$ Leibniz's logic-based calculus ratiocinator was especially appealing for Couturat. It governed the combination and manipulation of its ideographical symbols, in that it was made up of a set of rules that were meant to allow one mechanically to draw incontrovertible conclusions from premises. Couturat believed that a logical calculus conceptualized in this manner could provide an external and independent inference engine for the human mind that was driven by a set of logical rules.

The principles of univocity and irreversibility that underpinned Ido's precision and neutrality were applications of this notion of mechanical logic. They led Couturat to claim that Ido was a scientific improvement on Esperanto by making it more consistent and efficient than Esperanto. In his eyes these principles ensured Ido's structural objectivity,

\footnotetext{
${ }^{60}$ Couturat, Louis (1901). La logique de Leibniz d'après des documents inédits. Paris: Ancienne Librairie Germer Baillière. p. 61.

${ }^{61}$ Couturat (nr. 21), Pour la Langue Internationale, p. 60.

${ }^{62}$ Ibid. p. 11.
} 
propelling him to create and then promote it as freed of national interests. So Couturat's conception of Ido's objectivity, and therefore also its neutrality, was not only an expression of his notion of the powers of symbolic logic as means to generate structural objectivity. It was also driven by his reverence for Leibniz's characteristica universalis and calculus ratiocinator, which provided him with an example for his own early-twentieth-century project to create an international scientific language.

The following statement from an inaugural lecture Couturat gave in 1905 at the occasion of replacing of the French philosopher Henri Bergson for one year as professor of philosophy poignantly captures the distinctive ideological program that underpinned his scientific linguistic internationalism. In a declaration that resonated with his enthusiasm for Leibniz's project, Couturat made clear that logic was ideal "pour pouvoir exprimer d'une manière précise et adéquate les idées et les relations qu'elle étudie, et pour s'affranchir du vague et des équivoques dont tous nos langues sont entachées" ${ }^{63}$ Convinced that natural languages were imperfect because logic corresponded more directly to the timeless and placeless reality of objective truths, the dream of a rationalized language to enhance the communication became an urgent mission in a world that witnessed an upsurge of 'imperfect' national languages.

\subsection{Beyond national chauvinism}

Couturat's linguistic internationalism was not only driven by a distinct late-nineteenth- and early-twentieth-century objectivity politics. His relentless campaigning for Ido was also driven by a notion of its relevance for society that was forged in reaction to the Dreyfus affair, which held France in its grip in the 1890s and early 1900s. The scandal deeply divided France between progressive, liberal-minded Dreyfusards and conservative antiDreyfusards. Albert Dreyfus, a French artillery officer of Alsatian Jewish descent was convicted of having communicated a memorandum with French military secrets to the German Embassy in Paris and was sentenced to life imprisonment 1892. In 1896 it became apparent that a French army major was responsible, but the affair dragged on when Dreyfus was further accused in 1899. Many of Couturat's famous mathematics colleagues were engaged Dreyfusards, including his former professor Henri Poincaré, Paul Appell (1855-1930), Gaston Darboux, Jules Tannery, and Paul Painlevé (1863-1933). The antiDreyfusards represented nationalistic and militaristic France with figures including army general and minister of war Jean-Baptiste Billot (1869-98), minister of war Godefroy Cavaignac (1853-1905) and vehement anti-Semite and ideologue of the far-rightist movement Action Française Charles Maurras (1868-1952).

Poincaré intervened in the legal proceedings in 1899 at the request of Painlevé by

${ }^{63}$ Ibid. 
writing a letter that was read to the court. His letter was an attempt to expose the pseudoscientific nature of the probability theory that had been used in the graphological analysis of the memorandum that pointed at Dreyfus's guilt. He repeated his criticism in 1904 in a report that was jointly written with Appell and Darboux. This report played an important role in the eventual release and rehabilitation of Dreyfus as captain in the French army. Unlike Poincaré, Couturat was not directly involved in the affair. But his political convictions were nonetheless shaped by the event, propelling him to mobilize the powers of logic to create Ido, a language that could help ensure that the evils of military chauvinism displayed during the affair were relegated to the past. Couturat described the event as a "sad and shameful page in the history of the French Republic" and discussed it with his friends Léon and Russell:

\begin{abstract}
Ce n'est pas moins une triste et honteuse page de notre histoire, qui ne nous vaudra ni gloire ni sympathie dans le monde. Je me réjouis de la grâce et de la mise en liberté de Dreyfus; c'est un soulagement et le commencement de la réparation. (...) Mais il faut que la lutte continue (...). Oui, l'affaire Dreyfus aura été un bien pour la France, elle aura peut être sauvé la République si nous avons la force de en tirer les conclusions logiques et morales. ${ }^{64}$
\end{abstract}

A polemic on Emmanuel Kant's essay Perpetual Peace (1795) between Couturat and the politically conservative French literary critic Ferdinand Brunetière (1849-1906) offers some answers as to what Couturat meant with the betterment of the French Republic. In reply to Brunetière's suggestion that Kant viewed war as the ultimate vehicle of societal progress, Couturat argued that nothing could be further from the truth. He pointed out that Kant argued that war was only a temporary phase in society's development towards "the state of justice and international law" ${ }^{65}$ Couturat further argued that this Kantian development towards a state of international peace meant that "permanent weapons must disappear entirely with time" ${ }^{66}$ He concluded that Kant should not be confused with "apologists of force (disciples of Bismarck and Moltke), nor with the backward admirers of a military and theocratic society characteristic of the Middle Ages". ${ }^{67}$ Militarism was backwardness. Progress meant doing away with primitive notions of chauvinism and chivalric pride. The betterment of the French Republic meant resisting any form of nationalism and militarism.

In a letter to Russell, Couturat described national chauvinism as an "insatiable thirst for conquest and domination. This jingoism, cafe-concert patriotism [was] clearly a danger

\footnotetext{
${ }^{64}$ Louis Couturat to Xavier Léon. September 27, 1899. From the correspondence by Xavier Léon. Bibliothèque Victor Cousin, housed at the Bibliothèque de la Sorbonne in Paris.

${ }^{65}$ Couturat, Louis (1899). 'Correspondance,' Le Temps, March 27. [My translation]

${ }^{66} \mathrm{Ibid}$.

${ }^{67}$ Ibid.
} 
for world peace" ${ }^{68}$ Intellectuals must fight chauvinism instead of falling for the blind and brutal passions of the masses. Couturat's propagation of Ido as an internationally neutral and rational means to facilitate communication was an attempt to put into practice his own call for political engagement. For in his eyes, Ido could contribute to advancing the principles of justice and neutrality; it provided, "the indispensable condition for any international agreement (...)" ${ }^{69}$

\subsection{Leibniz as scientific internationalist avant la lettre}

With a strong belief in the duty of intellectuals as mediators of peace, Couturat's interest in an international language as a means to facilitate international communication fell on fertile ground during his research of the Leibniz Nachlass. Being both a mathematician and a philosopher, he read in Leibniz's philosophy an ideal synthesis between reason and language that confirmed and further enforced his notion of rational logic, providing him with the means to apply it to the imperfect nature of natural languages. In Couturat's eyes these had become equated with national chauvinism, a perspective which led him in the footsteps of Leibniz's universalism to articulate his very own and distinct early-twentiethcentury notion of scientific internationalism: the creation and promotion of Ido.

Leibniz's characteristica universalis might well have played a formative role on Couturat's scientific linguistic internationalism as a model for his own early-twentiethcentury linguistic intervention. But by suggesting that Leibniz was driven by the idea of establishing a language "that would replace all national languages" to facilitate an international unity of all thinkers Couturat created a model that convienently confirmed his own program:

The plan of establishing a universal language that would replace all national languages, both in commerce between different nations and especially in the relations between the learned of Europe, clearly proceeds from the intellectual movement of the Renaissance, which in renewing philosophy and the sciences had revealed the fundamental unity of the human mind and had given birth to the idea of the international unity of all thinkers, so well captured in the expression "republic of letters." (...) Reason became aware of its force and independence and strained to liberate itself from all the shackles of tradition and routine; men began to recognize that antiquity

\footnotetext{
${ }^{68}$ Couturat, Louis (2001[1899]). 'Lettre de Couturat à Russell (24.12.1899),' Schmid, Anne-Françoise (ed.), Bertrand Russell Correspondence sur la Philosophie, la Logique et la Politique avec Louis Couturat, pp. 216219. Paris: Éditions Kimé. p. 152. [My translation]

${ }^{69}$ Couturat (nr. 56) 'Lecture inaugural, Collège de France,' p. 6.
} 
could be surpassed in its knowledge of the universe and to glimpse the possibility of an indefinite progress. The human mind finally became aware of its own unity and the unity of science. This whole great movement of ideas - this renewal of the sciences and the reform of logic that was both its condition and its consequence - must naturally have suggested the creation of a philosophical and scientific language more logical than ordinary languages, one that would be shared by all thinkers in every country. $^{70}$

As an influential Leibniz scholar Couturat has contributed to a popular image of Leibniz as a scientific internationalist avant la letter, presenting him as one of the learned men who "had given birth to the international unity of all thinkers". Numerous books and papers since Couturat praise the seventeenth century German intellectual as possessing a "boundary transcending spirit" his times as an internationalist". ${ }^{72}$ But we must not project the twentieth century political values of internationalism as a positive movement that fosters national selflessness and global inclusion onto the ideas of an early modern scholar. Conscious internationalism that is the rise of internationalists as well as international movements that explicitly called themselves international - emerged only from the second half of the nineteenth century onwards as a reaction to the nation state.

This is not to claim that there was no international exchange of information and ideas before the nineteenth century. As pointed out by Lorraine Daston, just like the earlytwentieth-century scientific international language proponents, the members of the Republic of Letters were self-consciously engaged in international and collaborative networks as well as a conceptual space they defined in terms of cosmopolitanism and universality. ${ }^{73}$ As one of its members, Leibniz was engaged in a rich and extensive exchange of leading intellectuals from various European nations. During his travels to France, England, the Netherlands, and Italy, he became personally acquainted with many of the roughly 1,000 learned men with whom he was in correspondence throughout his life.

But Daston also makes clear that it would be an error to view these seventeenth century ideals of cosmopolitanism and universality as a reaction against nationality: "The

\footnotetext{
${ }^{70}$ Couturat, Louis (1901). The Logic of Leibniz (chapter 3 ['The universal language', paragraph 3). Translated by Donald Rutherford. Retrieved from the World Wide Web on May 27th, 2012: http://philosophyfaculty.ucsd.edu/faculty/rutherford/leibniz/ch3.htm

${ }^{71}$ Rescher, Nicholas (2002). Enlightening Journey. The Autobiography of an American Scholar. Lanham, Maryland (US). Lexington Books. p. 64.

72 Wiggins, D. (2006). Ethics: Twelve Lectures on the Philosophy of Morality. Cambridge: Harvard University Press. p 355 (in footnote 38).

${ }^{73}$ Daston, Loraine (1991). 'The Ideal and Reality of the Republic of Letters in the Enlightenment,' Science in Context (4)2: pp. 367-386.
} 
tolerance and freedom from prejudice they vaunted pertained largely to religion, not to nationality". ${ }^{74}$ Leibniz' philosophy was no exception to this rule. He was protestant by stock, but he argued that any Christian - regardless of denomination - could utilize his metaphysics as a natural theology to learn of the world's divine harmony and therefore also of the perfection of God. In Leibniz's eyes the only way one was supposed to live was according the Christian faith, this conviction was expressed in his interest in a scientific and cultural exchange with China.

Leibniz praised the "the ancient sages of China" for their philosophy, which "is pure Christianity, insofar as it renews the natural law inscribed in our hearts". ${ }^{75}$ But he argued that the first step towards a cultural exchange with China, which was to be facilitated by the characteristica universalis, was to make the Chinese Christians. In a letter to a Jesuit missionary he praised the efforts of the missionaries for their "propagation of the Christian religion and by the growth of solid sciences, which gives us means to admire the advantages of wisdom and the power of the author of things, and to better assist mankind". 76

In other words, for Leibniz assisting mankind was not about overcoming nationalism in any way. It was about promoting and spreading the Christian faith. The unity he sought to achieve through the implementation of his characteristica universalis was, above all, the unity of the Christians in Europe and China. Leibniz even proposed a crusade against the Ottomans in Egypt by a united Christian alliance. ${ }^{77}$

According to philosopher Peter Fenves this text can even be seen as providing a "method of planetary conquest", ${ }^{78}$ because it advised that linguistic differences between regions such as Africa, Arabia, America and New Guinea were to remain in place to make it more difficult for the "barbarians" to organize a collective revolt against their European masters. Fenves rightly points out that in the light of these recommendations Leibniz's efforts to construct a universal language was a means to ensure the supremacy of the Christian master: "the ability to translate one language into another is not only a scientific desideratum; it is also - and perhaps primarily - a means of mastery". ${ }^{79}$

\footnotetext{
${ }^{74}$ Ibid. p. 374.

${ }^{75}$ Cited in, Mercer, Christia (2004). Leibniz's Metaphysics: Its Origins and Development. Cambridge:

Cambridge University Press. p. 50.

${ }^{76}$ Cited in, Perkins, Franklin (2004). 'Leibniz's Exchange with the Jesuits in China,' in Lodge, Paul (ed.), Leibniz and his Correspondents, pp. 141-161. Cambridge: Cambridge University Press. p. 152.

77 Leibniz laid out this plan in a text called Consilium Aegyptiacum (1671), which is said to have inspired Napoleon's excursions to Egypt eighty years after Leibniz's death.

${ }^{78}$ Fenves, Peter (2005). 'Imagining an Inundation of Australians; or, Leibniz on the Principles of Grace and Race,' in Valls, Andrew (ed.), Race and Racism in Modern Philosophy, pp. 73-88. Ithaca, NY: Cornell University. p. 77.

${ }^{79}$ Ibid. p. 78.
} 


\subsection{For the glory of the French Republic}

Couturat's depiction of Leibniz as an exemplary scientific internationalist disguised the ideological differences between his own program and the programs of early modern learned men. Couturat's claims that Ido was meant to provide an open and disinterested means for global communication also disguised that his program was no less a means of mastery than Leibniz's program had been.

We saw that by creating and promoting Ido, Couturat claimed to exchange national interests for international interests. He stressed that any trace of personal and national interest was eliminated from Ido by virtue of its logical grammatical structure that was a product of the scientific principles of univocity, reversibility and maximum internationality. With these qualities it was supposed to represent the exact opposite of national languages and the ideology he claimed they represented, namely national chauvinism: "If any one is the victim of national prejudice it is he who proposes his own language as the international medium, and not the one who discards every national tongue, including his own, in favor of the international language" ${ }^{80}$ But his pursuit of Ido was itself an act of chauvinism on a regional as well as on a national level.

Firstly, Couturat was morally no different than his chauvinist contemporaries, in that in his eyes 'international' basically meant Europe and the U.S. The Belle Époque dominance of French, English, and German was an expression of the economical and cultural power in that period. Their power was to a large extent a product of overseas possessions in Africa and Asia, where national languages were enforced upon local communities in their politics of extracting wealth. Couturat argued that national languages needed to be replaced with Ido to root out national chauvinism in Europe and the U.S. But he never promoted it to enhance communication with and/or between communities beyond this region. In other words, with his blind focus on facilitating communication in Europe, he sustained the exclusion of Africa, the Middle East and the Far East. With the exception of the Far East, Couturat was no different than Leibniz. Couturat defined Europe itself even more narrowly. He claimed to have constructed a language that was "a quintessence of European languages", but he distilled a linguistic essence of Europe that excluded Slavic languages, to say nothing of other language groups. Ido's grammar rested heavily on the roman language tradition, meaning that its implementation would have been especially advantageous for French users.

Secondly, this last point hints at the nationalistic underpinnings of Couturat's project. Viewed in the context of longer tradition of French language politics, his project was, in fact, more French than European. For the tendency of viewing one's language as superior to other languages by virtue of its clarity and precision goes to the core of the modern self-perception of the French. Since the eighteenth century French played a leading

${ }^{80}$ Couturat, Louis (1905). 'An International Auxiliary Language,' Monist (15): pp. 142-146. p. 6. 
role as a means for communication among European political and cultural elite with the belief that it possessed a uniquely rigorous and logical structure. The French Royalist writer Antoine de Rivarol (1753-1801) famously fostered this view. In reply to the Berlin Academy's essay contest in 1783 on the question "What is it that has made the French language universal?" De Rivarol argued that of all European languages French was superior, because "par un privilege unique, est seul resté fidèle à l'ordre direct, comme s'il était tout raison (...). C'est de là que résulte cette admirable, base éternelle de notre langue". ${ }^{81}$

Couturat's promotion of a rationalized language as the one and only option for international science and diplomacy by virtue of these qualities strongly resonated with Rivarol's linguistic nationalism. In fact, it can be interpreted as an attempt to reclaim the international reputation of the French Republic as a dominant cultural force at a time when the French language had lost its exclusivity as the dominant language for Europe's cultural elite. There is little doubt that Couturat was preoccupied with the international reputation of his country. After labeling the Dreyfus affair as a "sad and shameful page in the history of the French Republic", he added that it earned the French "neither glory nor sympathy in the world". As such, his efforts to create and promote Ido can be seen as a means to repair and celebrate the glory of the French Republic by reconnecting France - but this time through Ido - once more to the Enlightenment narrative of scientific progress and universalism.

That Couturat's promotion was everything but a nationally disinterested affair did not remain unnoticed among the small group of men who had become Ido supporters. In 1916 a German chemist and former Ido enthousiast wrote to a member of the DAIAL that he had become increasingly aware of Couturat's tendency to claim and centralize the delegation's activities and aims, and to give Ido a French character: "Dazu kam die immer Deutlicher in den Vordergrund tretende Tendenz Couturat's, die sache bei sich zu Zentralisieren, zu monopoliseren und gleichzeitig dem Ido einen ausgepragt französischen Character zu geben." 82 The person who wrote these words will be the protagonist of the following chapter, in which it will become apparent that his involvement with Ido was no less an expression of particular interests.

\footnotetext{
${ }^{81}$ Rivarol, Antoine (1797). De l'Universalité de la langue Française. Paris: Chez Cocheris, ImprimeurLibraries. p. 32.

82 Ostwald, Wilhelm (1916). Letter to Leopold Pfaundler, 12.1.1916. Archiv des Branderburgischen Wissenschaft Institut, Berlin. Nr. 5277.
} 


\section{CHAPTER 3}

\section{Towards a German organization of the world: Wilhelm Ostwald and international language}

Wilhelm Ostwald (1853-1932), a Baltic-German chemist, was another early-twentiethcentury proponent of Ido. Ostwald was instrumental in establishing physical chemistry as an acknowledged branch of chemistry as a result of his pioneering work in the field of electrochemistry, which led to the discovery of the law of dilution (called Ostwald's Dilution Law). It was also a result of his aptitude as a practical organizer. In addition to publishing numerous textbooks on general and physical chemistry, he founded and edited the Zeitschrift für Physikalische Chemie in 1887. In that same year he accepted an invitation as Professor of Physical Chemistry at Leipzig University. Its chemistry department acquired world fame under Ostwald's guidance as students from across the globe flocked to Leipzig to study under his supervision. In 1909 he was awarded the Nobel Prize for his work on chemical equilibria, catalysis and reaction velocities. ${ }^{1}$

Ostwald became involved in the promotion of international language in 1901 when Couturat invited him to join the DAIAL. By then Ostwald was no longer active as a laboratory experimentalist. He invested all his time in a sociological and political program

\footnotetext{
${ }^{1}$ Later developments that can be contributed to physical chemistry are developments in nuclear chemistry (especially isotope separation), discoveries in astrochemistry and developments in the field of physiochemical properties.
} 
that proposed the reorganization of society. Since the turn of the century Ostwald's intellectual focus had shifted from chemical research to natural philosophy and cultural commentary. A theory called energetics, which he developed in the 1890s, was a reoccurring theme in Ostwald's countless publications and public talks. His experiments on thermodynamics led him to conclude that energy transmission - not matter - was the basis of physical phenomena. From about 1900 onwards Ostwald began to apply the principles of energetics to explain societal, cultural and psychological phenomena. ${ }^{2}$

In 1909 he established an organization called "Die Brücke". Its main aim was to solve the inefficient international transfer of scientific knowledge by organizing and standardizing the means with which information was communicated. One of its programmatic points was to promote and internationally standardize printing formats for scientific publications. Another objective was the creation of "a central station, where any question which may be raised with respect to any field of intellectual work whatever finds either direct answer or else indirect, in the sense that the inquirer is advised as to the place where he can obtain sufficient information". ${ }^{3}$

The "Brücke's" program also consisted of the promotion of Ido. Like Couturat, Ostwald initially defended Esperanto as the best option for an international language. But in 1907, after the delegation chose Ido, Ostwald had followed Couturat by supporting it, advocating its necessity for a more fluid and efficient international transfer of knowledge and information in pamphlets, letters, conferences and public talks until 1914.

Ostwald's involvement with international language remains largely unexplored. There has been a substantial interest by historians in Ostwald's post 1900 intellectual career. ${ }^{4}$ In these studies the subject of international language is either merely a passing reference along with Ostwald's many other organizational activities or it is entirely absent. A notable exception is Markus Krajewski's Restlosigkeit - Weltprojekte um 1900 (2006), which discusses Ostwald's internationalism in the context of other world projects round the

\footnotetext{
${ }^{2}$ Wilhelm Ostwald was a productive writer. He published over 45 books, hundreds of scientific papers, articles and 5,000 reviews.

${ }^{3}$ Ostwald, Wilhelm (1913). 'Scientific Management for Scientists: "The Bridge." The Trust Idea Applied to Intellectual Production', Scientific American (108): pp. 5-6. p. 6.

${ }^{4}$ For work on Ostwald's philosophical and sociological activities and their relationship with his work as earlier work as a physical chemist, see, Görs, Britta \& Psarros, Nikolaos \& Ziche, Paul (eds.) (2005). Wilhelm Ostwald at the Crossroads Between Chemistry, Philosophy and Media Culture. Leipzig: Leipziger Universitätsverlag $\mathrm{GmbH}$; Hakvoort, C. 'Science deified: Wilhelm Ostwald's energeticist world-view and the history of scientism,' Annals of Science 49(6): pp. 525-544. For work on Ostwald's monism, see, Braune, Andreas (2009). Fortschritt als Ideologie. Wilhelm Ostwald und der Monismus. Leipzig: Leipziger Verlag; Sobczyriska, Danuta. Czerwiriska, Ewa. (1998). Szientismus in der Praxis. Das Wirken Wilhelm Ostwalds im Deutschen Monistenbund, in: Philosophisches Jahrbuch (105) 1: pp. 178-194. For work on Ostwald's involvement with "Die Brucke", see, Hapke, Thomas (1999). 'Wilhelm Ostwald, the "Brücke" (Bridge), and Connections to Other Bibliographic Activities at the Beginning of the Twentieth Century,' in Bowden, Mary Ellen \& Hahn, Trudi Bellardo \& Williams, Robert V (eds). Medford, NJ: Information Today. pp. 139-147; Holt, Niles (1977). 'Wilhelm Ostwald's 'The bridge',' The British Journal for the History of Science 10(2): pp. 146-150.
} 
turn of the century. ${ }^{5}$ The biography Wilhelm Ostwald (1977) by Russian historians Naum Rodnyj and Jurij Solowjew is another exception. It includes a small chapter on his involvement with international language. ${ }^{6}$ The general absence of the subject of international language in studies of Ostwald's career stands in contrast to Ostwald's active and relatively lengthy engagement with international language. His involvement with international language lasted for a period of twelve years.

In his autobiography Lebenslinien (1933) Ostwald made it explicit that his efforts to promote international language were unsuccessful. This failure as well as the relative exoticism that is often associated with the project of promoting an artificial language as a new world language, provides some reasons for the relative disinterest by historians in this remarkable episode of Ostwald's career. There is also a tendency among historians to view his post-1900 activities as an indication of Ostwald's lack of intellectual focus, in that his sociological and cultural work is seen as thematically scattered and naively positivist. This last criticism goes back as far as the famous German sociologist Max Weber (1864-1920).

In 1909 Weber launched a vehement critique on Ostwald's sociology in an essay titled 'Energetic Theories of Culture'. He portrayed it as "rare artistry of presentation" that was logically mistaken, arguing that: "Considered from a logical point of view, his [Ostwald's] error is that he (...) takes certain forms of abstract thinking found in the natural sciences and makes them absolute standards for scientific thinking in general". ${ }^{7}$ Weber summarized this point by describing Ostwald's sociology as an act of transforming "the world-picture" of a single discipline into an entire "world-view". ${ }^{8}$ Weber the anti-positivist, saw Ostwald's sociology as the ultimate case of positivism.

Contemporary depictions of Ostwald's sociology continue to underline the positivist character of his worldview, and that it was viewed with skepticism by many of his colleagues. For instance, in his biography of the German historian Karl Lamprecht (18561915), one of Ostwald's colleagues at the University of Leipzig, historian Roger Chickering reminds us that: "It was easy to make fun of him (Ostwald). The fallacies in his thinking were transparent". ${ }^{9}$ It is therefore not surprising that his involvement with international language is seen in the same light, or perhaps even as one of Ostwald's strangest episodes in a period that is already considered as dubious on an intellectual level. This chapter takes Ostwald's positivistic worldview and his involvement with international language seriously by attempting to show that they were, in fact, part of a coherent and consistent ideological agenda that was driven by distinct political motives.

\footnotetext{
${ }^{5}$ Krajewski, Markus (2006). Restlosigkeit: Weltprojekte um 1900. Frankfurt am Main. Fischer Taschenbuch Verlag.

${ }^{6}$ Rodnyj, Naum I. \& and Solowjew, Jurij I. (1977). Wilhelm Ostwald (Biographien Hervorragender Naturwissenschaftler, Techniker und Mediziner). Leipzig: Teubner Verlag.

${ }^{7}$ Weber, Max (1984[1909]). "Energetic' Theories of Culture (translated by Mikkelson, Jon M. \& Schwartz, Charles),' Mid-American Review of Sociology (9)2: pp. 33-58. p. 33.

8 Ibid. p. 34.

${ }^{9}$ Chickering, Roger (1993). Karl Lamprecht: A German Academic Life (1856-1915). Atlantic Highlands, NJ: Humanities Press International, Inc. p. 296.
} 
But before zooming in on Ostwald's ideological agenda and the politics that underpinnend it, the first two sections offer a reconstruction of Ostwald's involvement with international language. The next section makes clear that like many of his scientific contemporaries Ostwald was confronted with national language differences on a daily basis during his scientific career. What distinguished Ostwald from them was that he promoted Ido without the external demand from his colleagues. Like Couturat, Ostwald pushed his own political agenda in promoting Ido.

Sections 4, 5, and 6 propose three specific intellectual components of Ostwald's ideological program. The first component was his theory of energetics. From his earliest involvement with international language, Ostwald applied one of its key-assumptions the notion of energy transfer of chemical reactions - as a conceptual framework to both articulate and solve what he viewed as the problem of national language diversity. Section 5 discusses the role played by Auguste Comte's sociology in Ostwald's internationalist program. Section 6 will make clear that Ostwald's internationalism, including his linguistic internationalism, was also an expression of nationalist interests to the extent that his ideas closely trailed the German expansionist ideas of Kaiser Wilhelm II. As soon as World War I broke out, Ostwald no longer promoted Ido. But the last section argues that, contrary to common belief, Ostwald continued to pursue an internationalist agenda during World War I, which included the promotion of an international language in the form of "Weltdeutsch".

\subsection{Ostwald's promotion of Ido part I: a Franco-German alliance}

Lebenslinien offers an interesting account of his earliest contact with international language. In the 1890s Ostwald's former physics professor, Arthur von Oettingen (18361920), familiarized him with Volapük, which was a relatively successful artificial international language in that period. It was not the first time that von Oettingen influenced Ostwald. By then he had already played an important role in Ostwald's career by having introduced him to the "Gedankenkreise" of thermodynamics when Ostwald was still a student at the University of Dorpat in Latvia. Ostwald recounts in his autobiography that he gained an interest in energy and the law of conservation, and the intellectual difficulties presented by the second law, by attending von Oettingen's lectures. ${ }^{10}$ And now his former professor also introduced him to the idea of an international artificial language.

What might have made Volapük appealing in Ostwald's eyes was that by the end of the 1890s it had gained many supporters - especially among what Ostwald referred to as "fortgeschrittenen Geister in die Kulturwelt". ${ }^{11}$ Ten years after Schleyer created Volapük, twenty-five periodicals were published on a regular basis. There were 283 Volapük

\footnotetext{
${ }^{10}$ Deltete, Robert J. (2007). 'Wilhelm Ostwald's energetics 1: Origins and Motivations,' Foundations of Chemistry (9): pp. 3-56. p. 14.

${ }^{11}$ Ostwald, Wilhelm (1933). Lebenslinien: Eine Selbstbiographie, band I. Berlin: Verlag Klasing \& Co.
} 
organizations in the world and 316 instruction books in over 25 languages circulated. But the success of Volapük lasted only for a brief period - allegedly because of Schleyer's intolerance towards suggestions for improvement. ${ }^{12}$

Ostwald's active involvement with international language began in earnest in 1901 after Couturat invited him to join the DAIAL. Several documents were enclosed in the letter, including an overview of the latest developments on the question of an international language and a copy of Histoire de la Langue Universelle (1903). ${ }^{13}$ Its authors had included it to give the delegation's mission intellectual gravity as well as to emphasize that it was part of a longer tradition of similar attempts. Associations with Leibniz, Descartes and Bacon suggested that their quest for an international language was part of a series of attempts by great figures in the history of science, boasting the importance of their mission to investigate the usefulness of an international language for science. They needed reputable scientists willing to promote it among their colleagues in order for their program to gain momentum in the scientific community. And in Ostwald they found a reputable figure.

Couturat, who was interested in the physical sciences and philosophy, might well have come across physical chemistry and Ostwald's name in the 1890s. By 1901 Ostwald was generally famous for his chemistry and philosophy, but during the $1890 \mathrm{~s}$ thermodynamics was a popular topic among scientists and philosophers. In 1893 Couturat published a paper in the $R M M$ on energy conservation, titled 'Sur L'Évolutionnisme et le Principe de la Conservation de L'Énergie'. ${ }^{14}$ What made Ostwald a valuable ally was that he had a strong international reputation as one of the founders of an internationally successful branch of physical chemistry.

Physical chemistry is currently not associated with cutting edge science and flashy headlines. But at the start of the twentieth century it was almost as cutting edge and trendy as molecular biology is today. ${ }^{15}$ Physical chemistry helped spur the development of nitrogen fixation and petroleum extraction on an industrial scale, processes which were considered as high-tech industrial science in that period. In fact, physical chemistry was so popular that the names of its founders "were familiar to the scientifically literate". ${ }^{16}$

Ostwald had not heard of Couturat. But a Franco-German alliance was born when he accepted the offer to join the delegation. His mission was to gain support for the cause in Germany. In his eyes the results of the DAIAL's attempts to gain support for the cause of international language were impressive, but limited to French speaking territory.

\footnotetext{
${ }^{12}$ Kim, Young, S. (1999). 'Constructing a Global Identity,' in Boli, John \& Thomas, George, M. (eds.), Constructing World Culture: International Non-governmental organizations since 1875, pp. 117-148. Stanford, California: Stanford University Press. p. 134.

13 Ostwald (nr. 11). Lebenslinien, p. 145.

${ }^{14}$ Couturat, Louis (1893). 'Sur L'Évolutionnisme Et le Principe de la Conservation de L'Énergie,' Revue de Métaphysique et de Morale (1)6: pp. 564-527.

${ }^{15}$ Servos, John (1999). Physical Chemistry from Ostwald to Pauling: The Making of a Science in America. Princeton: Princeton University Press. p. xv.

${ }^{16}$ Ibid.
} 
One of Ostwald's earliest promotional talks about international language was in 1903 at the Bayerische Bezirks-verein Deutscher Ingenieure. He opened his talk with a rhetorical question:

\begin{abstract}
Wenn ein Physikochemiker sich über die Angelegenheit der Weltsprache äussert, so setzt er sich der Frage aus: Wie kommt Saul unter die Propheten? oder deutlicher: Wie darf ein Naturforscher es wagen, in einer philologischen Sache seine Meinung geltend machen zu wollen ${ }^{17}$
\end{abstract}

Ostwald's answer was that the importance of international language stretched well beyond the narrow domain philology. International language was relevant for science in general, he reasoned, because of all institutions science was the most international. But he claimed that under the pressure of national language diversity, international congresses and publications were often highly inefficient events. Ostwald proposed Esperanto as the best option to smoothen and enhance the international transfer of knowledge in the scientific community in another talk at the Berlin Handelshochschule he introduced the by now familiar reference to the myth of Babel to illustrate Esperanto's usefulness:

Von allen Verkehrsmitteln ist das wichtigste aber die Sprache. Die biblische Geschichte von Turmbau zu Babel veranschaulicht uns aus das lebhafteste, wie allein durch die Störung dieses Verkehrsmittels, während alle Übrigen Bedingungen dieselben bleiben, die Möglichkeit einer gemeinsamen Arbeit so völlig zerstört werden kann, dass auch nicht einmal der Versuch zu ihrer Fortsetzung mehr gemacht wird. Und in unserer eigen Zeit habe wir mehrfach beobachten können, wie führende Nationen ihre Führerschaft verloren, nur weil sie im Gefühle ihrer Superiorität versäumten, fremde Sprachen zu Lernen und die fremde Arbeit auf ihrem Herrschaftsgebiete zu beachten. ${ }^{18}$

Like Couturat, Ostwald argued that international communication was obstructed by nationalist chauvinism. The two scientists also shared the notion that existing national languages and Latin were outdated and rusty vehicles for international communication. Ostwald opposed the German chemist Hermann Diels, who as we saw in chapter I

\footnotetext{
${ }^{17}$ Ostwald, Wilhelm (1903). Die Weltsprache. Vortrag gehalten am 4. december 1903 im Bayerische Bezirksverein Deutscher Ingenieure. Stuttgart: Frankh'sche Verlagshandlung.

${ }^{18}$ Ostwald, Wilhelm (1906). Die internationale Hilfssprache und das Esperanto. Vortag gehalten am 7. November 1906 in der Aula der Handelshochschule zu Berlin. Berlin: Esperanto Verlag Moller \& Borel. p. 10.
} 
promoted a return of Latin, by arguing that Latin was too complicated and inefficient. Ostwald also contended that a linguistic three-partite (English, German and French) was problematic for a proper transfer of knowledge, in that it meant a triple workload. For it required the time-consuming work of having to learn and master multiple languages as well as the difficult process of translating scientific texts. He also argued that the use of three languages made it simply too difficult to keep up with lectures and discussions at scientific conferences:

Meine eigenen Erfahrungen auf dem letzten internationalen Kongress für angewandte Chemie in Rom haben mir gezeigt, dass ein solcher Schritt schon deshalb unmöglich ist, weil nicht alle italienischen Kollegen eine der drei genannten Sprachen soweit beherrschen, dass sie unbehindert ihre Gedanken aussprechen können. ${ }^{19}$

The only way out of this situation, Ostwald claimed, was the adoption of an artificial international language. This would reduce the workload for scientists at international conferences and while preparing publications for international journals. The idea was that by virtue of its singularity and its efficient and easy to learn vocabulary and grammar, the international adoption of such a language meant that scientists no longer wasted valuable time and energy by translating their work into foreign languages as well as by having to learn multiple national languages.

Once again repeating Couturat, Ostwald also claimed that another major advantage was that its artificial character implied that it was disconnected from political and national interests. Its use contributed to the avoidance of strive and hierarchy between representatives from different nations. He pointed out that existing natural languages represented particular nationalities. This made the international use of any national language favorable for those who mastered it. The point was that in contrast to an artificial language, national languages did not offer a neutral platform for international communication.

Ostwald argued that because an artificial language could and should be based on scientific principles, it could be constructed in such a way that it was a more precise and objective vehicle for the transfer of scientific knowledge than any other language. In a paper titled 'The question of nomenclature', which published in Ostwald's only joined publication with Couturat titled International Language and Science (1910), he claimed that such a precise language was needed because "we scientific men suffer a good deal from the fact that the same words are frequently employed for the vague ideas of daily life as

${ }^{19}$ Ibid. p. 7. 
well as for the perfectly definite concepts of science". ${ }^{20}$ He added that: "where the chief question is one of precision of concepts, as in science, language must be regarded as a handmaiden, whose first duty is to obey. For language stands only in a secondary relationship to the independently developed and determined concepts of science, which have been already fixed by symbols assigned to them (...)". ${ }^{21}$

In other words, in Ostwald's eyes the designation of scientific knowledge in symbols and classification systems was consistent, objective, precise and internationally intelligible because they were the product of rational methods and deliberations. That was exactly what made them superior to natural languages. Ostwald argued that it was for this reason that an international language was in part already present in science itself.

If we take up a book or a paper dealing with mathematics (especially analysis) printed in a language, such as Japanese, which is quite unintelligible to us, we shall, nevertheless, soon succeed in finding out what it is about and often in understanding its main contents. (...) The same thing holds good in physics, and especially in chemistry; chemical formulae contain at the present day such detailed information concerning the relationship of the substances symbolized, that one might conceive the possibility of writing a chemical paper with formulae alone. ${ }^{22}$

Ostwald claimed that a blueprint for an international language could especially be found in mathematics: "Since in mathematics not only quantities, but also the operations, are denoted by universally understood symbols, it is already possible (...) to express long trains of mathematical thought in a manner which is internationally intelligible". ${ }^{23}$ In Ostwald eyes chemical formulae were an especially good example of science's internationalism, since its symbolism was intelligible to any trained chemist - no matter where he was from. Ostwald concluded that: "these well-known facts show that the problem of international language has already been partly solved in science". ${ }^{24}$

In Ostwald's eyes the task that lay ahead was the formulation of an international language that preserved this already "far-reaching internationality" ${ }^{25}$ Besides applying the concepts of logic to what Ostwald referred to as "this great process of purification" of language, Ostwald advised the appointment of "a certain number of persons" to collect the

\footnotetext{
${ }^{20}$ Ostwald, Wilhelm (1910). 'The question of nomenclature,' in Couturat, L. \& Jespersen, O. \& Lorenz, R. \& Ostwald, W. \& Pfaundler. L., International Language and Science: Considerations on the Introduction of an International Language into Science, pp. 61-68. London: Constable and Company Limited. p. 63.

${ }^{21}$ Ibid. p. 64.

${ }^{22}$ Ibid. p. 61.

${ }^{23} \mathrm{lbid}$. pp. 61-62.

${ }^{24} \mathrm{Ibid}$.

${ }^{25}$ Ibid.
} 
vocabulary of their scientific fields, and then appoint commissions "that represented whole groups of sciences to discuss the necessary principles, after which the details could be worked out and finally subjected to the examination and approval of the whole body" ${ }^{26} \mathrm{He}$ added that the international standardization of such a purified language on the basis of already existing scientific concepts "will probably require for their final settlement an international congress, at which the final decisions will be made". ${ }^{27}$

In the previous chapter we saw that Wilhelm Foerster experienced the deliberations at the Paris Metre Conference as a challenge because of the linguistic barrier he had to overcome. Ostwald, however, argued that the event was a shining example for the process of adopting an international standard for global communication. The outcome of the conference was an international treaty called the Metric Convention that put into effect new international standards for weights and measurements. It was signed by 18 countries in 1875. Ostwald presented this outcome as a testimony of the power of scientific deliberation and of scientists' natural tendency to cooperate smoothly on an international level.

Martin Geyer has pointed at the idealistic character of portrayals by scientists of both the proceedings and the outcome of the Meter onferences:

Proponents of the metric system (...) stressed its rationality. The strength of the system lay in its invariability, commensurability, and consistency, and its decimal structure that was not only simple and logical but supposedly also easy to learn. (...) Scientists had defined and controlled the new standards, and made them prescriptive; scientific expertise had conquered tradition. The Graeco-Latin foundation of the nomenclature was on the assumption that it created a unifying, truly international language, which allowed scientists of all nations to communicate with each other. ${ }^{28}$

Geyer points out that the process of establishing an internationally standardized meter system was, in fact, a highly political affair. The French prided themselves as the inventors of the metric system, but its Bureau de Longitude and the Academy of Science of Paris realized that the adoption and international regulation of international standard required some kind of selection procedure on an international level in order to get their standard accepted without too much controversy. Much like Couturat's move to organize an international gathering of experts in Paris to acquire international recognition for his

\footnotetext{
${ }^{26}$ Ibid. p. 67.

${ }^{27}$ Ibid. pp. 67-68.

${ }^{28}$ Geyer, Martin (2001). 'One Language for the World: The Metric Sytem, International Coinage, Gold Standard, and the Rise of Internationalism, 1850-1900,' in Geyer, Martin \& Paulmann, Johannes (eds.), The Mechanics of Internationalism, pp. 55-94. Oxford: Oxford University Press. p. 58
} 
language project, the political strategy of the French was to give an international commission of scientific experts some degree of authority in determining new standards. In doing so, their aim was to minimize the impression that it was - and had always been - a French endeavor.

In any case, Ostwald presented the establishment of a standard for weights and measurements as radiant example of scientific internationalism. He claimed that a standard for weights and measures had "conquered the world" and now it was time for an international language to conquer the world! ${ }^{29}$ The years 1906 and 1907 were Ostwald's busiest in terms his engagement to pursue this agenda. In 1906 he wrote to the Dutch chemist Jacobus van 't Hoff (1852-1911), a colleague and friend, that he spent most of his time on furthering the cause of international language. ${ }^{30}$ Ostwald wrote this letter after his return from America where he spent six months (from October 1905 to February 1906) at Harvard as exchange professor. His main mission in America was to lecture on physical chemistry, but he also used his time there to promote the international language through several promotional talks, first in Boston and Cambridge, and later in other places. ${ }^{31}$

One year later he wrote the same to his other friend and colleague, the Swedish chemist Svente Arrhenius (1859-1927): "Mein Jahr 1907 ist wesentlich mit Arbeiten für die Weltsprache ausgefühllt gewesen". ${ }^{32}$ In that same period he published numerous articles on the subject in the popular German press, including in the weekly magazine Die Woche, ${ }^{33}$ the illustrated magazine Reclams Universum, ${ }^{34}$ and in the Münchner Allgemeine Zeitung. ${ }^{35}$

Ostwald also attended the meetings of the DAIAL in Paris as a member of the committee. The meetings took place from 15 until 24 of October in Paris. Ostwald recounted that throughout the event, Couturat was "Den Geschaftsfuhrer". ${ }^{36}$ His secretary, Leopold Leau, was less involved in the deliberations of the delegation. He briefly attended one of the first sessions before withdrawing entirely from the event. He left only a minor impression on Ostwald. Couturat left a stronger impression on him, but his description of the Frenchman presents a sober portrait, bordering on an unflatering depiction:

\footnotetext{
${ }^{29}$ Ostwald (nr. 18), Die internationale Hilfssprache und das Esperanto, p. 9 [my translation].

${ }^{30}$ Ostwald, Wilhelm (1969).'Ostwald an van 't Hoff, 26/12 1906,' in Körber, H-G (ed.), Aus dem

Wissenschaftlichen Briefwechsel Wilhelm Ostwalds, vol. 2. Berlin: Berlin Akademie Verlag. p. 314.

${ }^{31}$ Ostwald (nr. 11), Lebenslinien, p. 150.

${ }^{32}$ Cited in, Solowjev, R. \& Rodnyi (nr. 6), Wilhelm Ostwald. Biographien hervorragender Naturwissenschaftler, Techniker und Mediziner, p. 338.

${ }^{33}$ Ostwald, Wilhelm (1907). 'Die internationale hiflsprache,' Die Woche, (47) (9-Jahrgang) November 23th: 2047-2048.

${ }^{34}$ Ostwald, Wilhelm (1907). 'Die internationale hilfsprache,' Reclams Universum (19) Februari 7th: pp. 438443.

${ }^{35}$ Ostwald, Wilhelm (1907). 'Der Kulturwert der Hilfsprache,' Allgemeine Zeitung (München), Beilage, (125) July 3rd: pp. 9-12.

${ }^{36}$ Ostwald (nr. 11), Lebenslinien, p. 164.
} 
Couturat war etwas junger als ich, ziemlich hoch gewachsen und hatte schlank ausgesehen, wenn er nicht die gebückte Haltung des Schreibtischmenschen gehabt hatte. Sein Haar war blond, helle Augen und eine stubenblasse Gesichtsfarbe gaben ihm ein unfranzösisches Aussehen. $\mathrm{Er}$ war verheiratet und seine Frau erwies meiner Tochter freundliche Gastfreundschaft bei gelegentlichen Besuchen. Der Haushalt war kleinbürgerlich und meiner Tochter erschreckte die Frau Professor zuweilen durch die Unbefangenheit ihrer Ansichten, denn diese schien erst vor kurzem eine klösterliche Erziehungsanstalt verlassen zu haben. ${ }^{37}$

The meetings brought Ostwald and Couturat together in person for the first time after a six-year correspondence. The previous letter exchanges between Ostwald and Couturat testifed of an amicable relationship. In Couturat, Ostwald found an authoritative expert on langue matters whose knowledge on logic, philosophy, and universal language projects was legendary. He also found a strong, determined leader him, who had the reputation of being the organizer of the First International Congress of Philosophy. This combination of intellectual prowess and practical organizational skills was appealing to Ostwald.

But in terms of personality and charisma Ostwald was more taken by the mysterious Louis de Beaufront, who attended the meetings to defend Esperanto on Zamenhof's behalf: "Mit grosser Aufmerksamkeit betrachte ich Herrn de Beaufront. (...) Er erwies sich als ein wohlgeplegte Persönlichkeit mit zarter Gesichtsfarbe, weiße Haare und Bart und von Verbindlichen wesen". ${ }^{38}$ Another member who drew Ostwald's attention was Gaston Moch (1859-1935), a former French soldier whose name was well known in pacifist circles. Besides noticing Moch's lively manner of presenting ("Seine rede begleitete er mit einem lebhaften, bis ins Groteske gesteigerten Miemenspiel (...)"), ${ }^{39}$ Ostwald recalled that he was surprised that Moch did not display the blind fanaticism exihibited by most Esperantists.

Ostwald's conception of Esperantists as fanatics was a prelude to the conflict that erupted immediately after the delegation decided to adopt Esperanto under the condition that it was to be improved according to the Ido project. Ostwaldwas initially satisfied with the outcome of the delegation's meetings: "Als dies alles geordnet war, kehrte ich nach Hause zurück, sehr ermüdet von den Anstrengungen, aber sehr zufrieden mit dem Ergebnissen" ${ }^{40}$ But his enthusiasm was short lasting, because on 4 November, one month after the meetings in Paris, Zamenhof sent Ostwald a lengthy letter that was filled with accusations, claiming that Couturat had hypnotized him. Zamenhof also requested Ostwald to mediate between the Esperantists and the delegation, because there were other

\footnotetext{
37 Ibid. p. 161.

38 Ibid. p. 163.

${ }^{39}$ Ibid.

40 Ibid. p. 169.
} 
attackers of Ido. ${ }^{41}$ One of the principal aggressors was the French philosopher and parapsychologist Emile Boirac (1851-1917). The mathematician René de Saussure (18681943), the brother of the famous Swiss linguist Ferdinand de Saussure, was an equally vehement and authoritative opponent. The problem for the Idists was that by 1907 Esperanto had a much larger group of supporters than Ido.

As result of this conflict, Ostwald decided to end his affiliation with the delegation in 1908. At that moment his correspondence with Couturat also ended abruptly. Their last exchange was about their battle with the Esperantists. Couturat encouraged Ostwald to hold firm in defense of Ido against vehement attacks by supporters of Esperanto. Worn out by the war with the Esperantists, Ostwald decided to discontinue his promotion of Ido as a member of the delegation. But while he ended his affiliation with the delegation, he remained loyal to Ido itself.

\subsection{Part II: the "Brücke" and the Monistic Alliance}

Ostwald's continued dedication to Ido is evidenced by the fact that he donated half of his 1909 Nobel Prize money to furthering its cause. ${ }^{42}$ In an attempt to by-pass the war between the Idists and the Esperantists Ostwald searched for a neutral ground from where he intended to continue the promotion of Ido. When he gained the support of a group of "several influential men" in Bern in 1911, he believed to have found this neutral ground in Switzerland. ${ }^{43}$ One of these men was "der unermüdlicher" Swiss reverend Friedrich Schneeberger (1865-1926). ${ }^{44} \mathrm{He}$ was an Ido pioneer in Switzerland. But he had previously been president of the Swiss Esperanto society. In this capacity he had led the second World Congress of Esperanto in Geneva in 1906.

Ostwald's and Schneeberger's plan was to mobilize the Swiss government to promote the creation of an international committee that was occupied exclusively with the question of an international language in the hope that Ido was once again selected as the best option. Their plans never materialized. But they had the support of Theodor Tobler (1876-1941), inventor of Toblerone and owner of the chocolate factory where it was produced. He was an active freemason as well as an avid supporter of the international peace movement in Bern, where in 1891 the International Peace Bureau was founded that brought together and coordinated the activities various European pacifist groups. ${ }^{45}$ Under

\footnotetext{
${ }^{41}$ Künzli, Andreas (2010). L.L. Zamenhof (1859-1917): Esperanto, Hillelismus (Homaranismus) und die "jüdische Frage" in Ost und Westeuropa. Wiesbaden: Harrassowitz Verlag. p. 268.

${ }^{42}$ Megill, Frank R. (1990). The Nobel Prize Winners: 1901-1937. Ipswich, MA: Salem Press. p. 193.

${ }^{43}$ Ostwald (nr. 11), Lebenslinien Berlin, p. 177.

44 Ibid. p. 178.

${ }^{45}$ Feuz, Patrick \& Tobler, Theodor (2001). 'Theodor Tobler (1876-1941): Selfmademan, Patron, Pazifist,' in Leimgruber, Yvonne (ed.), Chocolat Tobler: zur Geschichte der Schokolade und einer Berner Fabrik; Begleitpublikation zur Ausstellung "Chocolat Tobler - Eine Dreiecksgeschichte. Von 1899 bis heute" im
} 
Tobler's influence Tobler chocolate collecting pictures and posters were printed in Ido from about 1911 onwards.

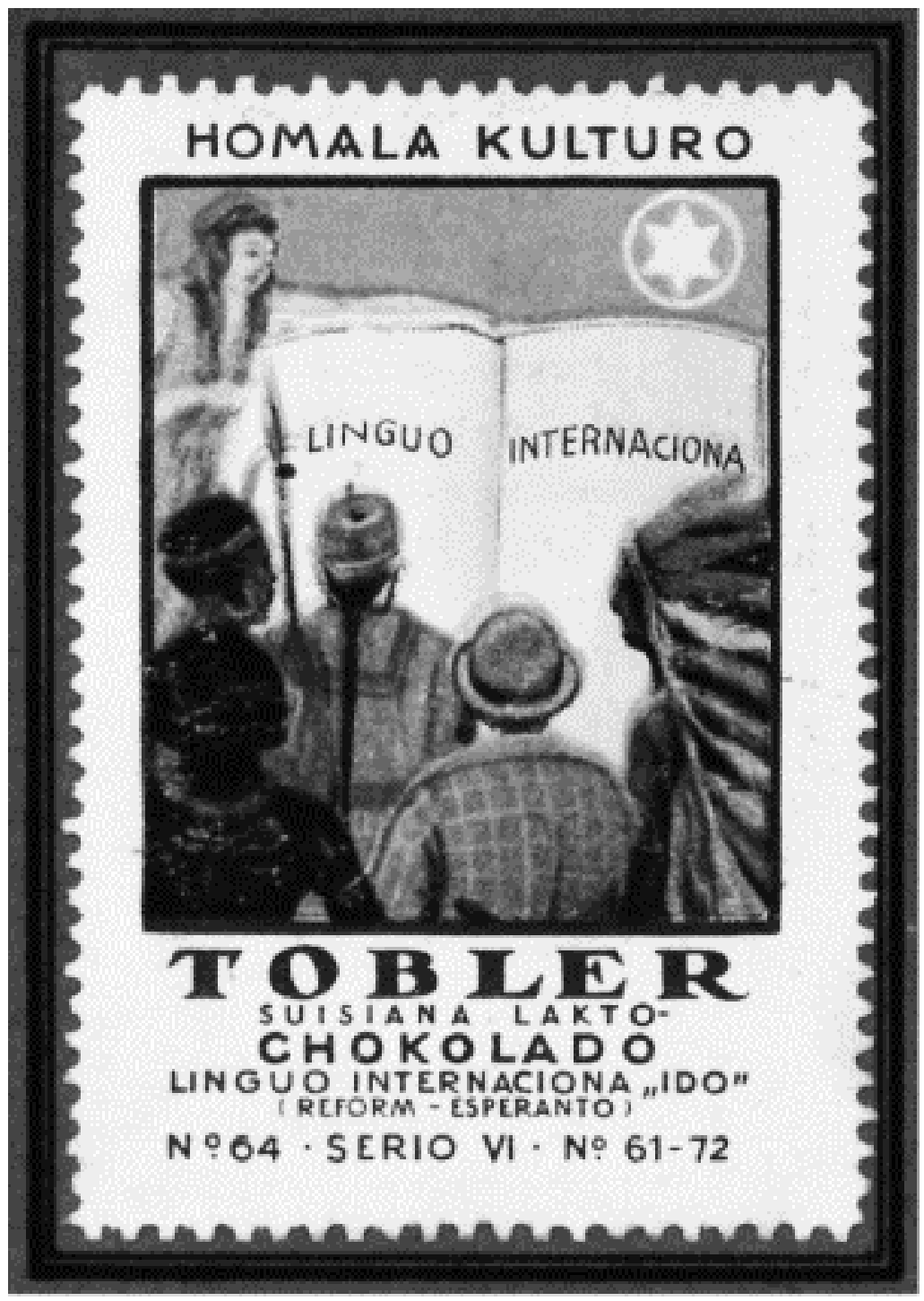

Toblerone card in Ido promoting the idea of international cultural exchange through Swiss "Chokolado". ${ }^{46}$

By 1911 Ostwald's promotion of Ido became part of a broader program to streamline, organize and standardize the means with which scientific knowledge was communicated internationally. In that year Ostwald spent another part of his Nobel Prize money to establish an organization in Munich that was supposed to execute the program, namely the "Brücke". The organization was a product of Ostwald's partnership with Adolf Saager

Kornhaus Bern. pp. 81-89. Bern: Historisches Institut der Universität Bern. p. 81.

${ }^{46}$ Retrieved from the Worldwide Web on November 5th, 2012:

http://www.swissworld.org/en/people/portraits_chocolate_makers/theodor_tobler/ 
(1879-1949), a German author, and Karl Wilhelm Bührer (1861-1917), a Swiss businessman. ${ }^{47}$ Bührer was the founder and editor in chief of Die Schweiz, a two-monthly magazine that focused on literature and art. He was also a proponent of an extensive standardization of the format of all printing material, which led him to establish the Internationalen Mono-Gesellschaft in 1905. The society produced promotional cards that were designed by young painters in the "Einheitsformat". The initiative was not a success. Buhrer's society dissolved in 1911, after which he moved to Munich to found the "Brücke" together with Saager and Ostwald.

The "Brücke's" program consisted of:

(...) the organization of scientific work, not from above downward, as hitherto, but from below upward, by first of all, introducing uniformity and affecting a saving of energy consumption in those things than can be rendered uniform without prejudice to the main task itself. Such are more particularly matters of detail relating to the technique of production and use of publications and books. By far the greatest part of science is, at the present day, recorded in the form of paper covered with writing or print, and consequently a practical and thoroughly efficient "get-up" of this fundamental tool of all intellectual work represents a problem of fundamental importance. ${ }^{48}$

This program of rendering the means with which information was circulated "uniform without prejudice" was basically a repetition - albeit on a broader scale - of his earlier claims about proposing an internationally standardized and rationalized language. He reasoned that organizing the international transfer of information prevented a great amount of energy waste. In addition to promoting Ido, one of the central activities of the "Brücke" was the promotion of a standard printing format called "Weltformat". Its advantage was a reduction of space in bookcases and libraries that would lead to a prize reduction of publications. By reducing space, it would ensure the feasibility of shelving a large volume of publications in a relatively small space. The promotion of the "Weltformat" was closely linked to another aim of the "Brücke", which was to create "a central station, where any question which may be raised with respect to any field of intellectual work whatever finds either direct answer or else indirect, in the sense that inquirer is advised as

\footnotetext{
${ }^{47}$ Hapke, Thomas (1998). 'Wilhelm Ostwald, the "Brücke," and Connections to Other Bibliographic Activities,' in Bowden, Mary E., Bellardo Hahn, Trudy, Williams, Robert V. (eds.), Proceedings of the 1998 Conference on the History of Heritage of Science Information Systems, pp. 139-147. Medford, NJ: Information Today. p. 141. ${ }^{48}$ Ostwald (nr. 3), 'Scientific Management for Scientists: "The Bridge." The Trust Idea Applied to Intellectual Production,' p. 6.
} 
to the place where he can obtain sufficient information". ${ }^{49}$

Ostwald envisioned that the "Brücke" would literally bridge national borders by linking up intellectual workers from all over the world quickly and efficiently. He described it as "necessary brain or central organ of humanity" where the world's total knowledge "organically" came together. And as pointed out, the promotion of Ido remained one of the programmatic key points of this international organization of intellectual work. In addition to dissolving language communication problems at conferences and in publications, Ido was supposed to greatly reduce the time and costs needed for producing international scientific journals. Ostwald pointed out that chemical societies of each nation had a separate abstracting service, all of which processed the total scientific output of the world into short abstracts:

It will be easily seen that this method is attended with great waste of energy. Not only are there three independent abstracting centers among Englishspeaking nations - one controlled by the American Chemical Society, another by the English Chemical Society and a third, in a certain measure, by the Society of Chemical Industry - but in addition to these there are at least five or six abstracting agencies in the German language (...). ${ }^{50}$

To realize his plan of creating an Ido abstracting service Ostwald attempted to introduce the inclusion of Ido abstracts in Die Zeitschrift für Physikalische Chemie. This attempt resulted in a confrontation with colleague, friend, and co-founder of the journal, the Dutch chemist Jacobus Henricus van 't Hoff (1852-1911). In 1902 Ostwald shared with van 't Hoff his enthusiasm for the idea of an international language for the first time. Initially, it seemed that van 't Hoff was interested. In 1903 he asked Ostwald to sent him the documents Couturat and Leau had sent around on behalf of the DAIAL. ${ }^{51}$ But from that moment onwards van ' $t$ Hoff never mentioned the subject again in his correspondence with Ostwald. In 1906 Ostwald wrote to van 't Hoff that he invested a large portion of his time in the promotion of international language. Van ' $t$ Hoff simply ignored the subject in his reply. Undeterred by his friend's silence on the subject, Ostwald introduced the topic to his friend once more in 1911 when he proposed to inclusion of Ido translations of article abstracts in Die Zeitschrift für Physikalische Chemie:

\footnotetext{
49 Ibib. p. 6.

50 lbid. p. 5

51 'van 't Hoff an Ostwald, 19/7 1903,' in Körber (nr. 30), Aus dem Wissenschaftlichen Briefwechsel Wilhelm Ostwalds, vol. 2, p. 304-305.
} 
Ich beabsichtige den lange überlegten und sorgfältig vorbereiten Plan auszuführen, als Vorarbeit für die vollständige Internationalisierung der chemischen Litteratur die "Zusammenfassungen“ am Schluße der Abhandlungen in unserer Zeitschrift in Ido zu übersetzen und sie in dieser Form den Abhandlungen bei zufügen. ${ }^{52}$

Van 't Hoff could no longer maintain his silence. He made it clear that as the journal's editor he would not witness the implementation of Ido:

$\mathrm{Zu}$ meinen großen Bedauern konnte ich leider, auch nach längerer Überlegung, den von Ihnen gewünschten Schritt zu Gunsten der Idosprache nicht mitmachen und ohne daß Sie hierin etwas unfreundliches erblicken müssen, teile ich lieber auch sofort mit, daß ich die Zeitschrift bei dieser Änderung nicht mehr mit meinem Namen stützen mochte. ${ }^{53}$

Ostwald interpreted his friend's message exactly how it was intended, namely as a refusal to support the implementation of Ido in their journal. Before citing back to van ' $t$ Hoff his own attempt at diplomacy - “(...) daß Sie hierin nichts unfreundliches erblicken müssen" 54 -, Ostwald lashed out at his friend for refusing to cooperate, making clear that: "Es handelt sich nicht um persönliche Empfindlichkeit, sondern um grundsätzliche Auffassungen". ${ }^{55}$ Van 't Hoff fell ill immediately after his last letter to Ostwald. In an attempt to rebuild a Brücke between him and van 't Hoff, Ostwald reported that he decided to postpone his plan to include Ido abstracts in Die Zeitschrift für Physikalische Chemie.

Ostwald's most concrete effort to apply Ido was a translation of the periodical table of elements. He had already proposed this plan in 1908 in an earlier mentioned article titled 'The question of nomenclature', pointed out that the formation of such a table required the definition of clearly defined concepts and words must be as short as possible: "Such long names as Wasserstoff or 'hydrogen' cannot be permitted (...)". ${ }^{56}$ In 1910 Ostwald finally published such an Ido translation, first in Couturat's Ido journal Progreso, ${ }^{57}$ and one year

\footnotetext{
52 'Ostwald an van 't Hoff, 4/1 1910,' in Körber (nr. 30), Aus dem Wissenschaftlichen Briefwechsel Wilhelm Ostwalds, vol. 2, p. 321-322.

53 'van 't Hoff an Ostwald, 7/1 1910,' in Körber (nr. 30), Aus dem Wissenschaftlichen Briefwechsel Wilhelm Ostwalds, vol. 2, p. 322-323.

54 'Ostwald an van 't Hof, 21/1 1910,' in Körber (nr. 30), Aus dem Wissenschaftlichen Briefwechsel Wilhelm Ostwalds, vol. 2, p. 324.

55 Ibid.

${ }^{56}$ Ostwald (nr. 20).'The question of nomenclature', p. 65.

57 Ostwald, Wilhelm. (1910). Pri La Kemiala Nomizado. Extraktita ek la revue Progresso N 27, 29 e 34 (Mayo,
} 
later in Die Zeitschrift für Physikalische Chemie.

Despite a general lack of support for Ido in the scientific community, Ostwald nonetheless continued to promote it as part of the "Brücke's" international organization of intellectual work. But by 1913 the relationship between Bührer and Ostwald had cooled down and their program remained without serious support. When no more publications appeared it became quiet around the "Brücke". The organization was officially terminated when in 1914 a bailiff sealed the Munich office. ${ }^{58}$ But the "Brücke's" end did not mean the end of Ostwald's campaigning for Ido and a broader international organization of society.

WILHELM OSTWALD

\section{LA PONTO}

(D I E B R Ü C K E)

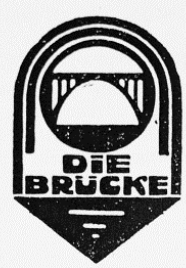

AUS DEM DEUTSCHEN IN DIE WELTSPRACHE $=$ „I D O “

OBERSETZT VON DR. OTTO LIESCHE

1911

EDITEYO „LA PONTO “ MÜCHEN

IM SELBSTVERLAG DER BROCKE MUNCHEN

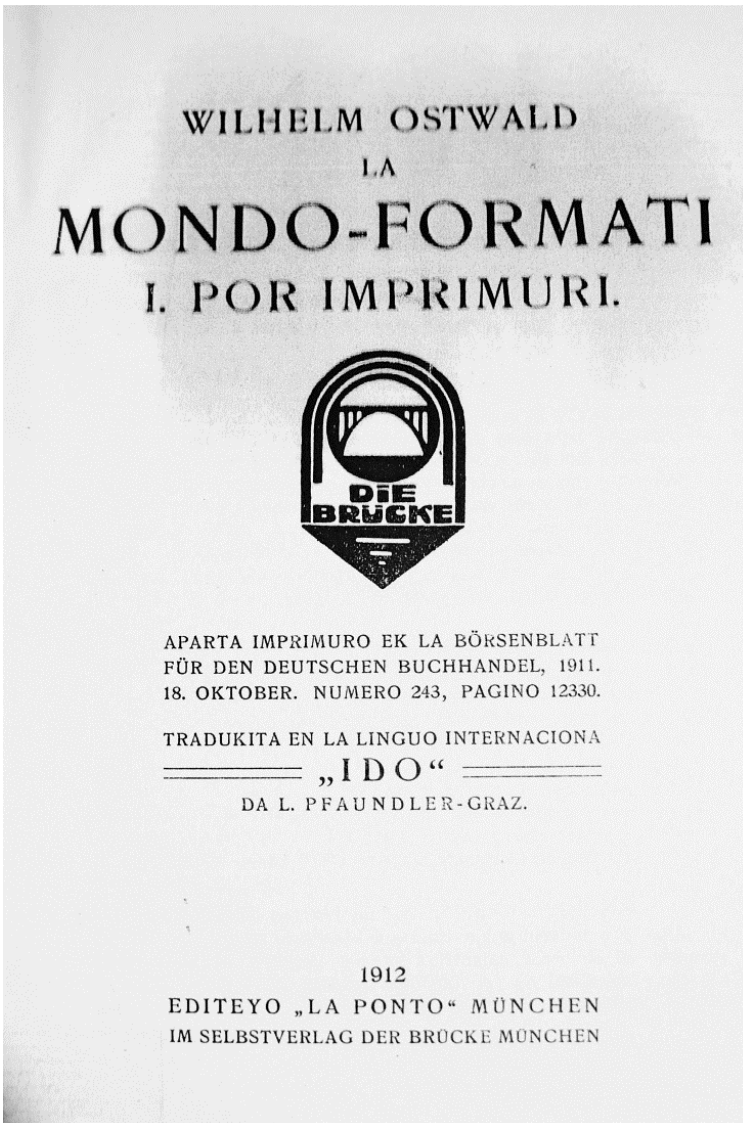

The promotion of the "Brücke" program was done with a total of half a million pamphlets, brochures, and books. The organization also issued 10.000 exemplars of a magazine that were sent for free to its members, 325 large libraries in the world, and 3,000 industrial tycoons during a six month period. ${ }^{59}$ In an attempt to increase Ido's popularity, many of these pamphlets and books were published in Ido.

Julio e decembro 1910). Paris: Librarie Ch. Delagrave.

58 Sachsse (nr. 51). 'Das Gehirn der Welt: 1912,' p. 71.

59 Sachsse, Rolf (2004). 'Das Gehirn der Welt: 1912,' in Weibel, Peter (ed.), Wilhelm Ostwald: Farbsysteme Das Gehirn der Welt, pp. 64-88. Ostfildern: Hatje Cantz Verlag. p. 65 


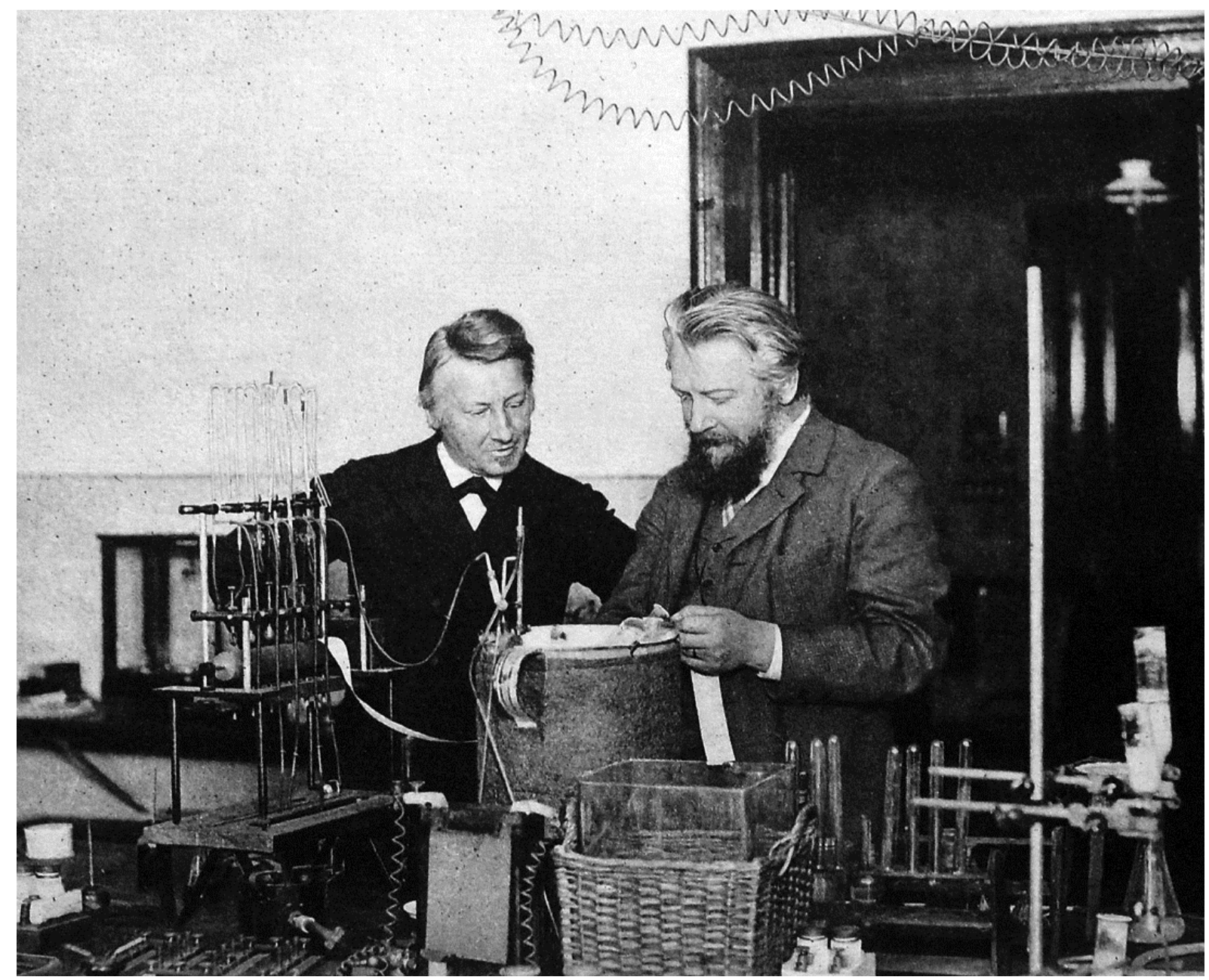

A photograph of van 't Hoff and Ostwald in the laboratory sometime before 1906. The original photo was published in the Zeitschrift für Physikalische Chemie, band 50, in $1905{ }^{60}$

\footnotetext{
${ }^{60}$ Retrieved from the Worldwide Web on August 6, 2012:

http://commons.wikimedia.org/wiki/File:Van_\%27t_Hoff_und_Ostwald_01.jpg
} 


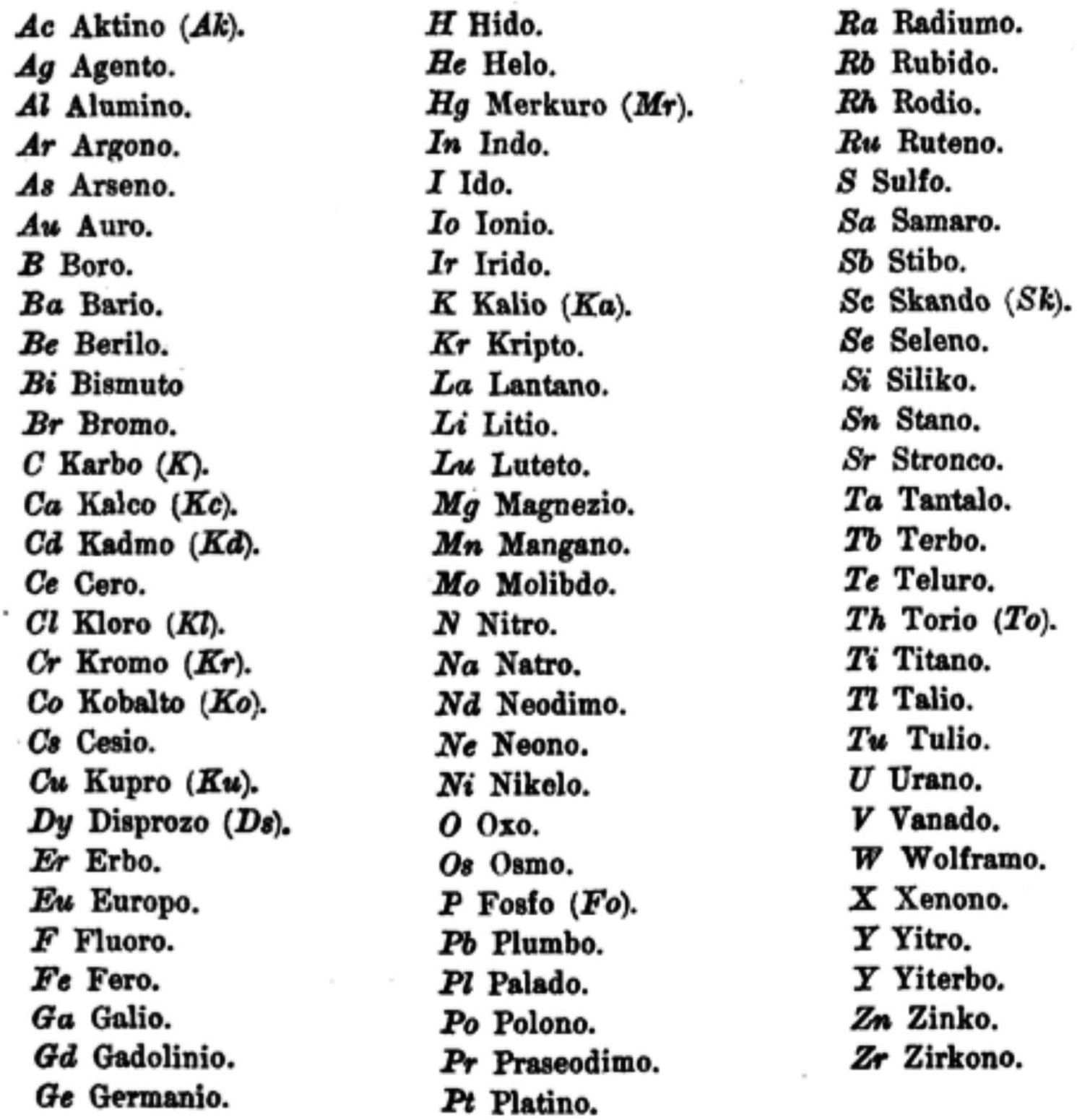

Ostwald's Ido translation of the table of elements in Die Zeitschrift für Physikalische Chemie. ${ }^{61}$

From 1911 onwards Ostwald articulated his international reform program as president of the German Monistic Alliance. The German zoologist Ernst Haeckel established the alliance in Jena in 1906. Haeckel was the driving force behind its ideological program and he founded the Monistic Alliance to promote and spread a scientific worldview called Monism. He claimed the aim was to transform society along its principles, making it the religion of the future.

Heackel's Monism was an extension of his battle for the acceptance of the Darwinian theory of descent. He was one of the most influential German experts of Darwin's evolutionary theory and a passionate promoter of the revolutionary and

${ }^{61}$ Ostwald, Wilhelm (1911). 'Chemische Weltliteratur,' Zeitschrift für Physikalische Chemie (76): pp. 1-21. p.8. 
irreligious conclusions of the acceptance of the theory of evolution. He claimed that mankind's development was the outcome of a biological transformation that was no different than the development of any other species, in that it was ruled by the principle of the survival of the fittest. With monism Haeckel meant the dominance of this evolutionary theory in sociology, philosophy and religion. He presented it as an alternative worldview to what he argued were the old fashioned and outdated dogmas of the church.

In 1910 Ostwald keenly accepted Heackel's request to become president of the Monistic Alliance. In this period the organization was at its height in terms of its membership. Between 1908 and 1910 the German Alliance and its daughter organizations in Austria, the Netherlands and Switzerland, had 7,000 members. ${ }^{62}$ Ostwald initiated the first International Monistic Convention in Hamburg immediately after his official inauguration. 4,000 participants attended the event. Ostwald also began to publish the series Monist Sunday Sermons (Monistische Sonntagspredigten), which were published during a period of three years. He wrote more than one hundred sermons that propagated monism, the need for a scientifically based secular worldview, educational reforms and Ido.

Ostwald's closely followed Haeckel's view of monism. In doing so, his mission was to free man from his supposed subordination to religious dogmas by replacing these with scientific accounts of phenomena in society and nature, psychological phenomena, and of issues of general well being of individuals and of society at large. But while Darwinism remained the ultimate scientific foundation for Haeckel, Ostwald propagated a unified scientific worldview that was based entirely on the principles of energeticism.

We saw that in his promotion of Ido and the broader program to internationally standardize the tools for intellectual work, Ostwald expressed this principle of energy dynamics to describe the process of international information transfer. Similarly, in his Sunday Sermons Ostwald mobilized the principles of energetics in all areas of life and society. But now his aim was to replace the church and its ethics with a new scientifically based ethics. Ostwald literally called for the need of a general religious disaffiliation. In one of his published Sunday sermons, titled "Kirchenaustritt", he claimed that the Monistic Alliance played an important role in convincing people to leave their church. ${ }^{63}$

Ostwald's presidency of the Monistic Alliance was viewed with skepticism. One of the reasons for this was his involvement with international language (his position on the church was another reason). The Kölnische Volkszeitung, for instance, reported that the German monists were unlucky with their new president: "Schon lange schüttelt man in besonnenen Kreisen bis weit in die Kreise seiner Kollegen den Kopf über das sonderbare literarische Gebaren des Leipziger Professors, der Über Esperanto und Pädagogik, Ultramonismus und tausend andere 'Probleme' seine platten Tiraden zum besten gibt". ${ }^{64}$

\footnotetext{
${ }^{62}$ Sobczyriska, Danuta. Czerwiriska, Ewa (1998). 'Szientismus in der Praxis. Das Wirken Wilhelm Ostwalds im Deutschen Monistenbund,' in Philosophisches Jahrbuch (105)1: pp. 178-194. p. 179.

${ }^{63}$ Rodnyj \& Solowjew (nr. 6), Wilhelm Ostwald. Biographien hervorragender Naturwissenschaftler, Techniker und Mediziner, p. 346.

${ }^{64}$ (1911). Kölnische Volkszeitung (51)106, February $5^{\text {th }}$ : pp. 1-2.
} 


\title{
3.3 From the periphery to the center
}

There is something to say for Ostwald's claims that his promotion of Ido and his program of an international organization of intellectual work was a practical answer to inefficiencies in the international transfer of scientific knowledge and information. As pointed out, by the turn of the century Ostwald had forged a new and internationally successful branch of chemistry. This placed him at the center of a scientific field that was rapidly internationalizing.

Ostwald's ascend to fame began in the periphery of the German scientific community. Born in Riga in 1853, Ostwald was the second son of German immigrants who had settled in German communities in Czar ruled Baltic provinces. He attended the city's Realgymnasium where he had his first experience with national language diversity. Its students were expected to learn French, English, Latin and Greek. ${ }^{65}$ Ostwald's ability to communicate in multiple languages later became a crucial asset for his role as scientific organizer. This early confrontation with multiple languages also played a formative role on his negative perception of national language differences:

\begin{abstract}
(...) man stelle sich nur den Geist eines heutigen Menschen vor, dessen Muttersprache deutsch ist, der etwa innerhalb einer polnisch redenden Bevölkerung seine Jugend verbracht hat, und der dann auf der Schule Lateinisch, Griechisch, Französisch und Englisch gelernt hat, und später etwa noch, von seinem Beruf gezwungen, hat Italienisch oder Holländisch dazulernen müssen. ${ }^{66}$
\end{abstract}

Between 1872 and 1878 Ostwald studied and obtained his habilitation in chemistry in Dorpat. He was a talented scientist. As early as 1879 , when he was only 26 , his work was favorably discussed in one breath with prominent chemists in The Philosophical Magazine: "The importance of the results obtained by Guldberg and Waage, and by Ostwald, must be apparent to every chemist." ${ }^{67}$ Ostwald returned to Riga as Professor of Chemistry at the Polytechnicum in 1881 after a spending several years in Dorpat as research assistant of the chemist Carl Schmitt (1822-1894). In Riga he finished his widely acclaimed Lehrbuch der allgemeinen Chemie and he established Die Zeitschrift für Physikalische Chemie in cooperation with van 't Hoff and Arrhenius. The journal soon became the leading publication for the field of physical chemistry. Ostwald remained its editor for almost thirtyfive years of this central node in an international network of scientists and engineers.

\footnotetext{
${ }^{65}$ Deltete (nr. 10), 'Wilhelm Ostwald's Energetics 1: Origins and Motivations,' p.4.

${ }^{66}$ Ostwald (nr. 17), Die Weltsprache, p. 4.

${ }^{67}$ Cited in, Walden, Paul (1904). Wilhelm Ostwald. Leipzig: Verlag von Wilhelm Engelmann. p. 31.
} 
Ostwald was located in the midst of a continuous international exchange of scientific knowledge as the editor for Die Zeitschrift für Physikalische Chemie. It was a busy crossroad for the exchange of ideas by scientists from France, Germany, America, Scandinavia, Holland, etc. During his correspondence with scientists of many nationalities Ostwald must have become more than aware that expressing ideas of foreign authors was difficult and time consuming. The translation of science's specialized jargon, detailed descriptions of experiments and complex classifications were especially challenging. The German chemist Frits Haber (1868-1934), an active contributor to Ostwald's journal, shared his thoughts on the difficulty of understanding and translating foreign trains of thought with Ostwald as follows:

Sie, Herr Geheimrat, haben mit recht betont, daß es zur Zeit schon eine ungemeine Schwierigkeit, ist (sic.) das Material an physicochemischer Publicistik zu lesen. Die Details machen die Schwierigkeit. Jeder ist an den Ideen und Resultaten, einzelne jeweils an den Details interessiert. Diese können in der einsprachigen Landespublicistik verbleiben. (...) Nichts ist leichter, als Thatsachen referieren, nichts schwerer, als Gedankengänge eines fremdsprachigen Autors im Excerpt knapp und scharf zum Ausdruck zu bringen. ${ }^{68}$

Ostwald's increasing visibility in- and outside the German scientific community, which was in part a result of the success of Die Zeitschrift für Physikalische Chemie, led to an invitation by Leipzig University. The offer was "a godsend" for Ostwald. ${ }^{69}$ For by the 1880 s, the Russian government was obstructing careers of German speaking academics in the Baltic provinces. The invitation not only offered him the chance to escape this hindering political situation; Ostwald's relocation from Riga to Leipzig meant that he moved from the periphery to the center of the scientific community. Excited about his friend's success, van 't Hoff wrote to Ostwald that: "Die Nachricht daß sie nach Leipzig kommen erfüllt mich mit höchster Freude. So können Sie dann im Zentrum Europa's ein Zentrum der Wissenschaft sein und gleichzeitig die Heimat zurückfinden". ${ }^{70}$

During the next ten years Ostwald successfully promoted van 't Hoff's and Arrhenius' theories, completed a great deal of research and transformed Leipzig into a world center for the study of physical chemistry. Students from all over the world flocked to Leipzig to study under Ostwald, creating a lively and international atmosphere with

\footnotetext{
${ }^{68}$ Haber, Fritz (1902). Fritz Haber in seiner Korrespondenz mit Wilhelm Ostwald sowie Briefen an Svante Arrhenius. Berlin: ERS Verlag. p. 59.

${ }^{69}$ Servos (nr. 15), Physical Chemistry from Ostwald to Pauling: The Making of a Science in America, p. 23.

${ }^{70}$ Van 't Hoff, Jacobus. H. (1969). 'van 't Hoff an Ostwald-10 Aug, 1887,' in Körber, H-G (ed.), Aus dem Wissenschaftlichen Briefwechsel Wilhelm Ostwalds, vol. 2. Berlin: Berlin Akademie Verlag. p. 210.
} 
regular gatherings of students from a broad range of nations. Numerous labs where physical chemistry was practiced were opened and research programs were initiated in the U.S. and in other countries. These newly established centers drew many young scholars to Leipzig to learn the traits of the discipline under the supervision of Ostwald himself. Emphasizing the high degree cosmopolitism of Ostwald's research group, John Servos paints a lively picture of the atmosphere in Leipzig:

Ostwald's research group grew, so too did a cosmopolitan spirit in his laboratory. (...) His daughter later recalled meeting students from all parts of Europe and America at these soirees, and some from Japan and Egypt. In fact, Ostwald's laboratory held a special appeal for foreigners. The Scottish chemist James Walker noted that even when he was with Ostwald in the late 1880s, his fellow students "were of varied nationality with seldom more than one example of each nation. As far as my recollection goes, there was only one genuine German research student. ${ }^{71}$

Ostwald not only managed to bring the world to his laboratory; he was also a frequent traveler. His most notable work-related trips occurred between 1902 and 1906 . He travelled to the U.S. on three separate occasions. In 1902 he visited Jaques Loeb's (18591924) institute in Berkeley, California. A second visit to the U.S. in 1904 brought Ostwald to the International Congress of Arts and Science and to the World Fair in St. Louis. The two events were showcases of national achievements, just like the London World's fair in 1851 and the Paris World's Fair in 1900 had been. In the previous chapter we saw that these events were characterized by a high degree of cosmopolitanism and richness of national diversity. ${ }^{72}$ Not surprisingly, Ostwald claimed that his experience at these events furthered his conviction that an international language was needed. He was, however, especially inspired by the fact that the Americans spoke one language: "In Amerika lernt jedermann, welches auch seine Muttersprache sei, Englisch, den der gesamte Verkehr dieses ungeheuren Landes spielt sich in dieser Sprache $a b^{\text {“. }}{ }^{73}$

Ostwald's last visit to the U.S. was as an exchange professor at Harvard from October 1905 to February 1906. The German government attempted to incorporate education and science in its foreign policies in the context of Germany's turn of the century world politics. From 1905 onwards it funded an exchange of German professors and American professors under this policy. Between 1905 and 1914, 29 German professors visited America. Ostwald was the first exchange professor who spent six months abroad.

\footnotetext{
${ }^{71}$ Servos (nr. 15), Physical Chemistry from Ostwald to Pauling: The Making of a Science in America, p. 49.

${ }^{72}$ Braune, Andreas (2009). Fortschritt als Ideologie: Wilhelm Ostwald und der Monismus. Leipzig: Leipziger Universitätsverlag. p. 36.

${ }^{73}$ Ibid. p. 5
} 
This position strengthened his sense of duty to further the international language cause. He viewed it as a symbol of the international character of science: "Mein Amt als Austauschprofessor war ein eindringliches Symbol der übernationalen Natur der Wissenschaft und so empfand ich die Aposteltätigkeit für die Weltsprache als einen organischen teil meiner Sendung". ${ }^{74}$

Ostwald's international lifestyle formed a strong contrast with his early years of relative isolation in Dorpat and Riga. His rise to fame as a pioneer of physical chemistry brought him from the periphery to the heart of the German scientific community; also placing him in the midst of an international scientific community. This was Ostwald's world when he accepted Couturat's invitation to join the DAIAL. It was a shrinking world in which national language differences were uneasy obstacles to a smooth transfer of scientific knowledge. But we saw that Ostwald's exposure to multiple national languages was not unique for early-twentieth-century scientists.

As pointed out in chapter II, the issue of national language diversity was frequently discussed by scientists at international conferences and in international journals towards the end of the nineteenth century and during the first decade of the twentieth century. But the principle of a single national language - natural or artificial - was not popular among early-twentieth-century scientists. Couturat's and Ostwald's failures to get wider support for Ido among their colleagues was a testimony of this.

Why, then, did Ostwald spend ten years of his career to promote an international language for and by science in spite of a general disinterest in the project by his contemporaries? Such tenacity indicates that he did believe in the necessity of an internationally standardized scientific language. Just as in Couturat's case, Ostwald's engagement for it was less driven by the concerns for the transfer of knowledge in the international scientific community than that it was pushed by his own ideological agenda.

\subsection{Ostwald's energetics}

The first and perhaps most obvious component of Ostwald's ideological agenda was his theory of energetics. Ostwald compared national languages to old houses in a modern world. He claimed that despite its deplored and worn out character people refused to tear this old house down because of sentimental reasons: "Freilich werden wir das alten Haus nicht ganz und gar abreißen und vernichten, dazu steckt eben zu viel von dem Leben unserer Vortfahren darin". ${ }^{75}$ With this metaphor Ostwald wanted to suggest that national languages no longer served their purpose in a world that was rapidly internationalizing. We saw that he claimed that their lack of precision and their multiplicity required a solution in the form of Ido. With these claims his argumentation was no different from Couturat's.

\footnotetext{
${ }^{74}$ Ostwald (nr. 11), Lebenslinien, p. 150.

${ }^{75}$ Ostwald (nr. 11), Lebenslinien, p. 143.
} 
But what distinguished Ostwald's claims on the need of international language from Couturat's was that he framed the problem of international communication in terms of energy efficiency. In fact, Ostwald seemed convinced of the importance of seeing human affairs from an energetic perspective - including the issue of national language diversity:

\begin{abstract}
Die Vorlesungen über Naturphilosophie im Jahre 1900 hatten mich veranlaßt, so ziemlich alle großen menschlichen Angelegenheiten vom energetischen Standpunkt aus zu betrachten und gegebenenfalls näher zu untersuchen. Bei dieser Gelegenheiten war mir die ungeheuerliche Energievergeudung aufgefallen, welche durch die Verschiedenheit der Sprachen bewirkt wird. ${ }^{76}$
\end{abstract}

In short, Ostwald's argument went as follows: why waste time and energy by clinging on to outdated and worn out languages when a single international language could greatly enhance the energy dynamics of international communication?

Ostwald's quest for establishing the importance of energetics began in the late 1880s. His interest in energy was triggered by van 't Hoff's studies in chemical dynamics as well as by work of the American scientist Josiah Willard Gibbs (1839-1903) on thermodynamics, which Ostwald translated into German in 1892. On the basis of their studies Ostwald developed the idea that energy considerations were not only important for chemistry, but for other sciences as well. This idea soon turned into a bolder program of establishing energetics - which was basically a generalized thermodynamics - as a unifying science. Ostwald argued that the principles of thermodynamics not only determined all material change, claiming that matter, such as atoms, ions, and molecules, was nothing more than bundles of energy. He argued that it was for this reason that the key to understanding all phenomena in the world was to ground their dynamism in the principles of energetics.

Ostwald presented his energetics as an alternative to the mechanical worldview. Since Descartes, Huygens, and Newton, physicists grounded their accounts of natural phenomena in the laws of mechanics. From their point of view reality was grounded in atoms, which meant that all phenomena were ruled by the mechanics of atoms and kinetic theory. But by the end of the nineteenth century many physicists discussed the validity of mechanics as the most basic science. By replacing matter (atoms and molecules) with energy, Ostwald claimed to offer an elegant and all encompassing account of nature's workings that was worthy of replacing the mechanical worldview. Emphasizing its importance as a unifying theory for all the sciences, he argued that as a basic theory for understanding all things in the world, it was of the greatest scientific and practical interest:

\footnotetext{
${ }^{76}$ Ibid. p. 141.
} 
The knowledge of laws of chemical energy is not only scientifically but practically of the greatest interest. All energy, which is employed in accomplishing the various purposes of industry, is derived from chemical sources, the combustion of fuel. Besides, each step that we take, every word that we speak, in fact every thought formulated by our brain, leads to sources of chemical energy; animals and plants throughout their whole existence are based primarily upon chemical energy and its laws, and the ultimate problems of biology are in every respect chemical. ${ }^{77}$

Theoretical physicists Ludwig Boltzmann (1844-1906) and Max Planck (1858-1947) initially received Ostwald's program with interest. And they had reasons to take him seriously. Firstly, as pointed out, by the 1890s Ostwald had established himself as a successful chemist with a solid international reputation. Secondly, Ostwald was not alone in advocating the principles of energetics as an alternative for mechanics. Georg Helm (18511923), a German mathematician, had also developed and promoted an energetic theory. In 1887 he presented it in a book titled Lehre von der Energie. And thirdly, Ostwald's and Helm's attempts to formulate an alternative foundational account for atomism enjoyed the support of Ernst Mach (1838-1916), who was one of the leading physicists in that period. In 1892 Mach presented his objections to the atomic theory in his lecture 'The Economical Nature of Physical Research. ${ }^{78}$

Boltzmann and Planck, who were then still young and relatively unknown scientists, invited Ostwald to present his theory of energetics at a large congress in Lübeck that was organized by the Versammlung Deutscher Naturforscher und Ärzte. ${ }^{79}$ Helm presented a supporting paper on "the present state of energetics". Ostwald's speech, which was titled Die Überwindung des wissenschaftlichen Materialismus, eloquently and challengingly proposed that the theory of mechanical atomism was untenable and that it did not serve its purpose as a basic and fundamental account that united the physical sciences. ${ }^{80}$ Instead, energetics offered a complete and measurable account of all phenomena. Boltzmann, however, was not convinced and launched a frontal attack on Ostwald's position by arguing that it was proven that all natural phenomena could be explained mechanically. He

\footnotetext{
${ }^{77}$ Ostwald, Wilhelm (1932[1883]). 'Ostwald on Chemical Energy “A Classic Science”,' The Science News-Letter, (21)577: pp. 278-280. p. 279.

${ }^{78}$ Rife, Patricia (2007). Lise Meitner and the Dawn of the Nuclear Age. Boston: Birkhäuser. p. 13.

${ }^{79}$ Established in 1840, the association was the German equivalent of the British Association for the Advancement of Science. Its main objective was to promote scientific collaboration between scientific disciplines and to promote science in society.

${ }^{80}$ Ostwald, Wilhelm (1895). Die Überwindung des wissenschaftlichen Materialismus. Leipzig: Verlag von Veit \& Comp. p. 6.
} 
concluded that energetics was simply an inadequate theory and that it was a mistake to drop atomism. The controversy was generally interpreted as a defeat for energetics. Boltzmann was supported by a younger generation of physicists - including Max Planck and Arnold Sommerfeld (1868-1951) - that would later influence an entire generation of German physicists.

But Robert Deltete points out that Ostwald saw his confrontation with Boltzmann as a confirmation of his ascent as an original philosopher. ${ }^{81} \mathrm{He}$ confidently continued to promote the energetic theory as a unifying science of sciences. In 1901 Ostwald established the periodical Annalen der Naturphilosophie to do this. For it was basically a platform to endorse and defend the principles of energetics as a foundation for science. He also presented it as a foundation for a cultural philosophy. Ostwald turned his energetic theory into a cultural philosophy for the first time in the Annalen by translating the dynamics of energy transfer into a normative statement. The result was a golden rule: "Vergeude keine energie, verwerte sie". $^{82}$

Ostwald even turned to Kant to that claim his golden rule of energy efficieny was nothing less than a categorical imperative, arguing that it was literally one's duty in the Kantian sense of the word to adhere to the laws of energy transfer for the improvement of the world. He reasoned that adherence to the principles of energetics was the just thing to do because injustice only triggered resistance, making it the sinful path of energy waste:

Die energetische hat seine Quelle in unausweichbaren natürlichen Gegebenheiten, in welche der Mensch hineingeboren ist und kennzeichnet sein Verhältnis zur Umwelt und die Stufe der von ihm erreichten Kultur. Die Kultur aber ist ein Erzeugnis der Vergesellschaftung und Kants Imperativ weist sich als eine Antwort auf die Frage aus: welche Bedingung stellt der zweite Hauptsatz für das Gedeihen der Gesellschaft? Die Antwort ist: Gerechtigkeit, weil jede Ungerechtigkeit Widerstand und damit Energievergeudung bewirkt. Und damit stellt sich der kategorische Imperativ als ein Sonderfall des energetischen heraus. ${ }^{83}$

Ostwald also presented an energetic theory of happiness in the form of a mathematical formula: $\mathrm{G}=k(\mathrm{~A}-\mathrm{W})(\mathrm{A}+\mathrm{W}) \cdot{ }^{84}$ He presented this equation with the basic principles of energetics in his Monistic Sunday Sermons as a scientifically based ethics for the individual and social life of his contemporaries. He claimed that the equation could be used to

\footnotetext{
${ }^{81}$ Deltete, Robert (1983). The Energetics Controversy in Late Nineteenth-Century Germany: Helm, Ostwald and their Critics, Volume II. Ann Arbor, Mich: University Microfilms International.

82 Ostwald (nr. 11), Lebenslinien, p 320.

83 Ibid. p. 313.

${ }^{84}$ Ostwald, Wilhelm (1905). 'Theorie des Glückes,' Annalen der Naturphilosophie (4): pp. 459-474.
} 
calculate one's happiness. G is Gluck (happiness), A is Arbeit (energy used doing useful work) and $W$ is Widerstand (energy wasted in overcoming resistance).

Ostwald's promotion of Ido was clearly an expression of this all-encompassing energetic reform-of-society program. His idea was to minimize energy waste by adopting a single language for the international communication of scientific knowledge. But by promoting this his all-encompassing energy reform program, Ostwald pursued an agenda of enhancing the status of the scientists in German society.

Ostwald was not alone in promoting such an all-encompassing scientific reform program. In fact, several of his scientific contemporaries in Germany presented similar reform programs. These shared a promise of improving the individual and social life in society. Russell McCormmach points out, however, that such programs were attempts to reclaim the scientists' role as Kulturträger, or purveyors of culture. During the Wilhelmian era, German physical scientists continued to cling on to this traditional notion of scientists, prescribed that men of science were part of the nations' elite. ${ }^{85}$ Their quest for true knowledge was seen as a creative process few were intellectually capable of and its products were seen as benefitting the entire nation. But towards the end of the nineteenth century a widespread fear emerged among scientists that Germany's rapid industrialization after 1870 had reduced their role in society to nothing more than suppliers of technological advancements. The new industrial complex Ostwald had helped to create challenged the traditional image of scientists as purveyors of culture.

As scientific disciplines became tied up with industrial purposes the image of science as a creative and culturally relevant endeavor to society was replaced by an image of science practical, efficient and highly specialized. Now science was increasingly seen as a highly specialized endeavor its practitioners were losing rapidly losing their authority as purveyors of culture. Scientists were increasingly becoming a part of society. Some even claimed that science was reduced to little more than a production machine of details useful only for maintaining the industrial complex. ${ }^{86}$ Ostwald's efforts to rebuild bridges between scientific disciplines and between science and society - which included his efforts to enhance the energy efficiency of the international transfer of knowledge - was an attempt to reverse this sudden inflation of the scientist's credence in Germany.

\subsection{Ostwald's appropriation of Comte}

The objective of reclaiming the scientists' authority as a purveyor of culture was a propellant for Ostwald's international organization program. To legitimize this program he appropriated Auguste Comte's (1798-1857) positive philosophy, with which he became

\footnotetext{
${ }^{85}$ McCormmach, Russell (1974). 'On academic Scientists in Wilhelminian Germany,' Deadalus (103)3: pp. 157171.

${ }^{86}$ Ibid. p. 162
} 
familiar during his early years at the university of Leipzig. In this period his search for such a universal theory was influenced, if not triggered, by several colleagues at the University of Leipzig. The two most influential were the German historian Karl Lamprecht (1856-1915) and the German psychologist Wilhelm Wundt (1832-1920), who is generally considered as the founding father of modern psychology.

The three men formed a tight group of intellectuals called the "Leipzig Circle" that upheld this tradition. ${ }^{87}$ They met frequently on occasions during which the three men expressed the wish to formulate a grand holistic system unifying the sciences in discussions fueled by considerations of the theories of Darwin, Spencer, and particularly Comte. ${ }^{88}$ Comte's philosophy was appealing to scientists who were seeking to forge a grand unifying theory because of its premises that scientific knowledge was the only valid and true knowledge, and that society operated according to laws in the same way the physical world operated according to the laws of nature.

But what made Comte's sociology particularly attractive was that it provided a powerful teleological framework to legitimize the authority of the scientist as the designated organizer of society. It consisted of a progression of three stages of man's moral development: the theological, the metaphysical and the positive stage. Comte branded the positive stage as the scientific stage. In it man was finally capable of improving and rationalizing society. It was this emphasis on scientists as the guiding class of society that offered the Leipzigers a powerful argument to claim the relevancy of their scientific work beyond the scope of individual disciplines and specific industrial branches. ${ }^{89}$

Wundt, Lamprecht and Ostwald each proposed an analysis of society's progressive development in the form of Comte's teleology, but with their own scientific discipline at its center. Wundt battled to make clear that it was the ultimate task of psychology to establish the fundamental laws that ruled man's psyche in that same way the physical sciences established the laws of physical causality in a quest to legitimize psychology as a proper and socially relevant science. His idea was that these fundamental principles could eventually be applied to help individuals cope with modern life. In his ten-volume study

\footnotetext{
${ }^{87}$ For a more extensive description of the intellectual influences on the Leipziger Circle, see, Smith, Woodruff D. (1991). Politics and the Sciences in Germany, 1840-1920. New York/Oxford: Oxford University Press.

${ }^{88}$ Chickering (nr. 9), Karl Lamprecht. A German Academic Life (1856-1915), p. 295.

${ }^{89}$ In the late nineteenth century obviously not everybody was as keen as the Leipzigers to embrace a positive view on modern society. Many interpreted what they perceived as an increase of nervousness and anxiety among modern individuals as a negative byproduct of modernization. Some even went as far to claim that it was a form of decay. The French poet Charles Baudelaire (1821-1867) was one of the advocates of this view, which he presented in Le Spleen de Paris (1868). His grim but seductive analysis of modern life as the root of a deeply felt uneasiness with the increased fluidity of society inspired a string of late nineteenth-century artists and psychiatrists to adopt a similar perspective on the negative aspects of modernity. In Germany, for instance, Friedrich Nietzsche famously deplored the noise, stench, and haste brought about by the modern world as a place where "restlessness, haste, and hustling grow continuously (...)" and where "the individual, faced with this tremendous machinery, loses courage and submits." Nietzsche, Friedrich (1968[1901]). Will to Power. Translated by Walter Kaufmann. New York: Vintage Press. p 33.
} 
Völkerpsychologie (1900-1920) Wundt proposed a psychology of societies, or folk psychology, that designated cultures as mental collectives. He claimed that the structure of 'a folk's' psychology could be reduced to certain fundamental laws in the same way the behavior of individuals could be accounted for. Wundt's idea was that the application of these fundamental laws to contemporary society would contribute to its improvement.

Lamprecht promoted a positivist strain of history writing. His twelve-volume magnum opus Deutsche Geschichte (1981-1909) presented human history as a more or less as a continuous march of progress. Inspired by Wundt's folk psychology, Lamprecht articulated a socio-psychological history of man in which he described culture as a psychic state that permeated the whole of life of the individuals that belonged to it. Lamprecht's progressive history tracked the psychological maturation of the German culture with the aim of yielding knowledge of the psychic maturation of the Germans that could contribute to a regeneration of the German nation. ${ }^{90}$

Like Lamprecht and Wundt, Ostwald promoted a Comptian teleological and positivistic history of society's progressive development. It was inspired by Wundt's folk psychology, in that it offered a broadly psychological view on man's historical development. But instead of emphasizing a progressive psychic maturation of man, Ostwald claimed that the development of man's psyche lagged behind the one and only force in history that was truly progressive: the incessant progress in science and technology. He argued that advances in transport and communications technology had occurred so rapidly during the second half of the nineteenth century, that man needed a helping hand to be able to keep up with the high demands of modern life.

Comte emphasized society's moral development in three stages, but Ostwald presented history in terms of society's organizational development in four stages. In the first stage of society's history individualism reigned supreme: "Es ist also das isolierte Leben des Einzelnen als der primitive Zustand (...)" ${ }^{91}$ The second stage emerged out of man's realization that the individual could accomplish his goals much more efficiently by working together. This awareness led to a period of excessive socializing. Eventually a society developed in which the individual was completely integrated into the group to the extent that every form of individualism was strongly suppressed. This suppression reached its highest point during the Middle Ages when the individual was tightly bound to church and state. The third stage began in the fourteenth and fifteenth centuries, when science and rational thinking emerged out of a reaction against this suppression of the individual.

Ostwald argued that his own time was in the midst of the third phase and that the fourth and final stage was already visible in the international scientific community. He presented its international culture as a model for the development of society at large in the direction of a tightly integrated international community: "Ein höhere Stufe der

\footnotetext{
${ }^{90}$ Chickering (nr. 9), Karl Lamprecht. A German Academic Life (1856-1915), p. 320.

${ }^{91}$ Ostwald, Wilhelm (1913). 'Internationalismus und Brücke,' Brücken-Zeitung. Zeitschrift für Organisierung der Geistigen Arbeit (5-6): pp. 1-20. p. 4. Archiv der Berlin-Brandenburgischen Akademie der Wissenschaften, nr. 5839.
} 
Entwicklung können wir in unserem Wirtschaftsleben nachweisen. (...) Das letzte Jahrzehnt des 19. und das erste des 20. Jahrhunderts sind gekennzeichnet durch die zunehmende Zusammenfassung der individuellen Wirtschaftstätigkeit zu immer größeren Komplexen". 92

The increasing assimilation and integration of the scientific community was supposed to mark the beginning of a transformation of the entire world into what Ostwald referred to as "a scientific unity": "Zwar die zunehmende organisatorische Zusammenfassung der ganzen Welt zu einer wirtschaftlichen Einheit ist nicht mehr rückgängig zu machen, sie wird sich vielmehr in nächster Zeit noch viel starker entwickeln, als es bisher der Fall war". ${ }^{93}$

But we saw that Ostwald was not entirely optimistic about the progress of the international scientific community. He argued that stately and private interests still partly governed these larger scientific complexes of cooperation and unity. The use of national languages in the international scientific arena was one of the manifestations of stately interests that obstructed the effcient transfer of knowledge. It was exactly for this reason that a rational organization of the transfer of scientific knowlegde was needed. Because weeding out the remnants of the outdated culture of individualism in science ensured that international science could most effectively and efficiently play its role as the motor behind the increasing unification of the word.

But while Ostwald maintained that his goal was to weed out individual interests in science, we saw that his reform program was an expression of the late nineteenth and early twentieth politics by German scientists to reestablish themselves as purveyors of culture. In other words, Ostwald appropriated and adapted Comte's teleology to legitimize a program served to enhace the status of the German scientists. The next section argues that his program was also an expression of stately interests.

\subsection{A German organization of the world}

By claiming that nationalism represented the most backward tendency in modern society, Ostwald clearly positioned himself as an internationalist and a pacifist. What made nationalism backward in his eyes was that its representatives (politicians and state officials) still displayed a high degree of individualism: "Wir haben gesehen, daß die Staatliche oder politische Organisation der Welt sich gegenwärtig noch im Zustande des Individualismus befindet und daß erst weinige und verhältnismäßig schwache Fäden bisher gesponnen worden sind, welche diese Individuen zu einer höheren Gemeinschaft zu verbinden beginnen". ${ }^{94}$ Ostwald's program was supposed to thicken and multiply the "weak and relatively few" of communication threads between nations.

\footnotetext{
92 Ibid. p.7

93 Ibid.

${ }^{94}$ Ibid. p. 14-15.
} 
In doing so, it would relegate national conflicts to the past. For the idea was that the increased efficiency of the transfer of knowledge (organized and communicated by internationally standardized means) facilitated a dissemination of culture that would break the barriers of isolation between nations by uniting people across the globe: "Die Ursache, welche die Kriege in Zentraleuropa hat verschwinden und im allgemeinen hat zurücktreten lassen, ist uns allen wohl bekannt. Sie liegt in dem Fortschritt der Kultur, welche die Völker vereinigt". ${ }^{95}$

In Ostwald's eyes, this culture of harmonious cooperation was exemplied in the process of science production. This is how he envisioned it in its most pristine form: "Die Wissenschaft ist ein Land, welches die Eigenschaft hat, um so mehr Menschen beherbergen zu können, je mehr Bewohner sich darin sammeln; sie ist ein Schatz, der um so grösser wird, je mehr man inn teilt. Darum kann jeder von uns in seiner Art seine Arbeit tun, und die Gemeinsamkeit bedeutet nicht Gleichförmigkeit“. ${ }^{96}$

Ostwald description of science as a separate country makes clear that he was keen to point out that scientists were a unique bunch. They shared the disinterested and noble urge to further humanity's knowledge of the world by virtue of their rational approach to it. With this description Ostwald clearly alluded to the ideal of the seventeenth century Republic of Letters. For he claimed that during the Middle Ages there was a lively traffic between scholars and researchers from different countries. It was at this point that science possessed a common language in the form of Latin that facilitated this lively exchange of knowledge regardless of any ongoing wars between nations:

So erkennen wir denn auch, daß von jeher ein lebhafter wissenschaftlicher Verkehr zwischen den Gelehrten und Forschern verschiedener Länder stattgefunden hat, unabhängig von den Meinungsverschiedenheiten, ja von Kriegszuständen, welche zwischen verschiedenen Nationen bestehen mochten. Während des Mittelalters hat sogar die Wissenschaft eine gemeinsame Sprache, die lateinische, besessen, und wir wissen, daß in der ersten Blütezeit der Universitäten internationale Gelehrte von einem Lande zum andern gewandert sind und an den Universitäten, welche insgesamt eine große zusammenhängende Korporation darstellen, überall Unterkunft, Schüler und Einfluß zu finden sicher waren. ${ }^{97}$

But as pointed out, Ostwald argued that the international character of the scientific community had been strongly diluted since the Middle Ages as science developed into a

\footnotetext{
95 Ibid. p. 15.

${ }^{96}$ Cited in, Walden (nr. 67), Wilhelm Ostwald, p. 1.

${ }^{97}$ Ostwald, Wilhelm (1912). 'Der Internationale Organisation der Chemiker,' Annalen der Natur- und Kulturphilosophie (Zwölfter band), pp. 217-233. Leipzig: Verlag Unsema G.M.B.H. p. 217.
} 
servant of the nation. Consequently, national languages replaced Latin and Ido was obviously meant to restore the lively and interest-free communication that science once exhibited. In other words, by executing the "Brücke's" program, Ostwald quite literally attempted to engineer a revival of the ideal of the seventeenth century Republic of Letters.

Ostwald's international reform program appeared to be about restoring the disinterestedness of sciencemaking, but his program was meant to benefit one nation especially: Germany. He claimed that Germany was the inevitable point of departure of his program "Es gelingt niemals, die internationale Organisation in einem bis dahin bestehenden Vakuum auf einmal zu beschaffen, sondern es sind immer lokal begrenzte und bedingte Anfangsstadien notwendig (...). So haben auch wir mit Bewußtsein unsere international gedachte Arbeit zunächst auf München und auf Deutschland beschränkt (...). ${ }^{98}$ Significantly, Oswald added that Germany was also the best place to initiate the organization of the world, because in doing so it would continue to count as one of the leading nations in the world. For in his eyes, there was no doubt that Germany was a leading power in Europe. He argued that in addition to its economical and industrial might, Germany was a leading nation of culture simply because modern science and technology had their home there. To quote Ostwald: "die Wissenschaft und Technik (...) [hat] ihre Heimat zu unserer Zeit vorwiegend in Deutschland aufgeslagen". ${ }^{99}$

In view of Ostwald's chauvinistic tendency to present Germany as a leading nation of science and culture, it turns out that his international reform program was, in fact, a strategy to foster and even expand its status as a leading nation in the world. That this was the case is further evidenced by Ostwald's contention the international organization was close to the heart of every true German, because it helped Germany to retain her leading role in what he referred to as a "peaceful contest of Nations". In fact, he argued that as a leading nation one of Germany's highest ambition was, and had always been, to foster humanity as a whole. Therefore the objective for every German was to bring glory to Germany by living up his/her noble duty of taking the lead in the advancement of humanity. For the completion of this vast undertaking would be the crown on the nation:

Wenn es uns gelingt, das Gefühl für den Wert nicht unserer Arbeit, aber unserer Zwecke und Ziele derart im deutschen Volk zu erwecken, daß die von uns erwünschte und erbetene tatkräftige Förderung in absehbarer Zeit eintritt, dann hoffen wir, ein Erhebliches dafür tun zu dürfen, was jeden Deutschen zutiefst im Herzen liegt. Wir dürfen hoffen, an unserem Teile dazu beizutragen, daß in dem friedlichen Wettbewerb der Nationen unserem deutschen Vaterlande der Kranz zufällt, dessen Gewinnung von jeher unser höchster Ehrgeiz gewesen ist, daß wir Deutschen uns in dem großten

\footnotetext{
98 Ostwald (nr. 91), 'Internationalismus und Brücke,' p. 18.

${ }^{99}$ Cited in, Reinbothe, Roswitha (2006). Deutsch als internationale Wissenschaftssprache und der Boykott nach dem Ersten Weltkrieg. Frankfurt am Main: Verlag Peter Lang. p. 36.
} 
Organismus der gesamten Kulturwelt zu Verwaltern der geistigen Güter der gesamten Menschheit entwickeln. ${ }^{100}$

It seems, then, that a sense of national superiority vis-à-vis other nations drove Ostwald's organizational internationalism and therefore also his promotion of Ido. His engagement to promote it was an act of sustaining Germany's role as a leading nation of (organizational) culture and science. This agenda resembled Couturat's, whose creation and promotion of Ido was ultimately an attempt to sustain France's status as a leading nation of culture in Europe.

But Ostwald's and Couturat's chauvinistic internationalisms were not the same, because in contrast to Couturat, Ostwald explicitly expressed imperialist aspirations for his international reform program. Ostwald envisioned the international arena as a "a new kind of 'Africa', a new continent waiting to be colonized": "Ein neues derartiges "Afrika", ein neu zu besiedelnder Kulturkontinent liegt im Internationalismus vor uns, dessen Besiedelung bereits im Gange ist" ${ }^{101}$

In view of this statement it appears that to some extend Ostwald's organization the world's intellectual work was an attempt to seize Germany's share of the world. This ambition was a manifestation of Germany's foreign politics under Kaiser Wilhelm II and King of Prussia, who ruled the German Empire and the Kingdom of Prussia from 1888 to 1918. Around the time when Ostwald laid out the "Brücke's" program, Wilhemine Germany had strong ambitions to acquire more regions in the southeast, harboring dreams of establishing an empire that outmatched those of rivaling European powers.

Driven by the urge to rival Britain's and France's empires, the Kaiser encouraged German colonial efforts in Africa and the Pacific to scramble unclaimed regions in Africa and Asia. Germany acquired Southwest Africa (Namibia since 1990), Kamerun, Togoland (Togo and Ghana), and parts of East Africa (Burundi, Rwanda and Tanganyika). In Asia islands in the pacific and the territory of Kiautschou in northeast China were acquired. The Kaiser also fostered closer economic relations with the Ottoman Empire. He did this by initiating the construction of the Berlin-Bagdad railway in 1903 to connect Berlin with the Ottoman Empire. In 1906 the Anatolian Railway hired two German architects to build the northern terminus of the Bagdad railway in Istanbul, the Haydarpaşa Terminus. ${ }^{102}$

Just like these initiatives, Ostwald's international scientific organization of intellectual work was an attempt to turn the dream of a vast German Empire into reality. But instead of building railway lines or exchanging goods, he promised a future Germany as a central traffic station where the world's knowledge was processed and made accessible.

\footnotetext{
${ }^{100}$ Ostwald (nr. 91), 'Internationalismus und Brücke,' p. 20.

101 Ibid. p. 19.

102 McMeekin, Sean (2010). The Berlin-Baghdad Express: The Ottoman Empire and Germany's Bid for World Power. Cambridge: Harvard University Press.
} 


\subsection{World War I: Ido abandoned, internationalism continued}

Ostwald abandoned the "Brücke's" program in 1913. He continued to promote Ido for one more year as the president of German Monistic Alliance. But the start of World War I marked an end of Ostwald's engagement for Ido, leading Ostwald to align himself with the interests of his fellow countrymen. The war stirred up a strong unifying movement in Germany, which is commonly known as the "Burgfrieden". It was a temporary agreement between previously opposing German political parties to not discuss their disagreements in public. The agreement was made possible by a sudden shared interest among German politicians, intellectuals and scientists to unite against foreign nations. ${ }^{103}$

One of the earliest manifestations of a shared agenda among German intellectuals was a 1914 proclamation known as the "Manifesto of Ninety-Three", which was endorsed by ninety-three prominent German scientists, scholars and artists. The proclamation concerned Germany's violation of Belgian neutrality at the start of World War I by invading it as well as the subsequent harm inflicted upon its civilians by German soldiers. It stated that these accusations were untrue and that any acts of harm done upon the Belgian population were therefore acts of self-defence. ${ }^{104}$ Ostwald and several members of his close intellectual circle, including Ernst Haeckel, Fritz Haber, Karl Lamprecht, Wilhelm Wundt and Max Planck, undersigned the proclamation to declare their support of the German actions in Belgium.

The manifesto marked the beginning of a battle between German intellectuals and their allied counterparts usually referred to as "Die Krieg der Geister". ${ }^{105}$ It is generally interpreted as marking a radical break with scientists' pre-World War I agendas of international cooperation and universalism. Stephan Wolff's study on German physicists during "Die Krieg der Geister" is a typical example of this tendency. Wolff juxtaposes preWorld War I internationalism to World War I, describing its agenda as "based on the universality of natural knowledge as well as on the necessity of a widespread, unrestricted communication and exchange of information." ${ }^{106}$ He suggests that as soon as World War I broke out, scientists simply abbandoned this agenda as they turned into uncritical spokesmen of nationalist propaganda under the influence of warmongering talks by their fellow countrymen.

The idea that World War I marked an abrupt departure among scientists from the

\footnotetext{
${ }^{103}$ Sondhaus, Lawrence (2011). World War One: The Global Revolution. Cambridge: Cambridge University Press. p. 182.

${ }^{104}$ (1914). 'Manifesto of the Ninety-Three German Intellectuals', WW I Document Archive: 1914 Documents. Retrieved from the World Wide Web on October 2nd, 2012: http://wwi.lib.byu.edu/index.php/Manifesto_of_the_Ninety-Three_German_Intellectuals ${ }^{105}$ The phrase "Krieg der Geister phrase stems from the title of a 1915 German book Der Krieg der Geister: Eine Auslese deutscher und ausländischer Stimmen zum Weltkriege 1914 by Hermann Kellerman.

${ }^{106}$ Wolff, Stefan L. (2003). 'Physicists in the "Krieg der Geister": Wilhelm Wien's "Proclamation",' Historical Studies in the Physical and Biological Sciences, (33)2: pp. 337-386. p. 338.
} 
ethos of international cooperation and national disinterestedness goes back to Robert Merton's essay 'The Normative Structure of Science' (1942). In it he claimed that in its most enlightened form the "ethos" of modern science includes four sets of institutional imperatives: universalism, communism, disinterestedness, and organized skepticism. But when society opposed these values, science also no longer functioned in its pristine form. Merton argued that the "Krieg der Geister" was a case in point of this second situation, in that society overpowered science's universalism by imposing nationalist loyalties on scientists:

\begin{abstract}
When the larger culture opposes universalism, the ethos of science is subjected to serious strain. Ethnocentrism is not compatible with universalism. Particularly in times of international conflict, when the dominant definition of the situation is such as to emphasize national loyalties, the man of science is subjected to the conflicting imperatives of scientific universalism and of the ethnocentric particularism. The structure of the situation in which he finds himself determines the social role that is called into play. The man of science may be converted into a man of warand act accordingly. Thus in 1914 the manifesto of ninety-three German scientists and scholars - among them, Baeyer, Brentano, Ehrlich, Haber, Eduard Meyer, Ostwald, Planck, Schmoller, and Wassermann - unloosed a polemic in which German, French and English men arrayed their political selves in the garb of scientists. ${ }^{107}$
\end{abstract}

This distinction between on the one hand pre-World War I science as disinterested and universalistic, and World War I science as nationalistic and chauvinistic on the other, disregards that nationalist agendas underpinned internationalist claims and initiatives by scientists before the war broke out. The nationalist and imperialist agenda of Ostwald's preWorld War I international reform program indicates that abstractions such as universal cooperation and the well-fare of humanity were less important for scientists in that period than commonly assumed.

Merton's distinction also falsely suggests that scientists dropped their internationalist agenda as soon as World War I broke out. Ostwald continued to promote his international reform program during the war. But only now he presented it as what it had been all along, namely as the first steps towards a German organization of the world. He even envisioned a future world order that was to be a product of a German organizational culture that supplanted an "outdated" Latin world culture with Paris as its

\footnotetext{
${ }^{107}$ Merton, Robert K. (1973) 'The Normative Structure of Science', in Merton, Robert K. (1973). The Sociology of Science: Theoretical and Empirical Investigations, pp. 223-280. Chicago, IL: University of Chicago Press. p. 271.
} 
metropolis. Ostwald argued that the representatives of the Latin world culture were politically and scientifically stuck in a state of individualism to the extent that its inhabitants could not even understand the cultural progress could be achieved by organizing: "Die Menschheit schreitet durch das Herdentum zum Individualismus und vom Individualismus zur Organisation fort. Die Franzosen und Engländer (...), stecken wissenschaftlich wie politisch noch so tief im Individualismus, daß innen die Möglichkeit fehlt, den kulturellen Fortschritt, der in der Organisation liegt, überhaubt nur zu begreifen". ${ }^{108}$

Ostwald even contended that Germany was by far the most scientifically and politically advanced nation, claiming that the most brilliant organizational minds had always belonged to Germany, and that it was through their efforts that its cultural influence had expanded vastly. As a result, Germany became the central crossroad for the international scientific community: "Hierdurch ist Deutschland zunehmend zum Verkehrsmittelpunkt der gesamten Wissenschaft geworden". ${ }^{109}$ And he furthermore claimed that if Germany had become the university of the world, it was because it was one could learn at German colleges what could be learned only in exceptional cases in the rest of the world:

\begin{abstract}
Darduch sind wir eben zu der grundsätzlichen Überwindung der veralteten lateinischen Kultur gekommen, innerhalb deren der Fortschritt der Wissenschaft in individuellster Weise von den Einzelleistungen besonders begabter Persönlichkeiten abhängig war. Wir haben das Entdecken zu organiseren gewußt, und wenn Deutschland im letzten Menschenalter die Universität der Ganzen Welt geworden war, so lag es daran, daß man in den deutschen Lehranstalten das Entdecken lernen konnte, wozu in der übrigen Welt nur ausnahmsweise Gelegenheit war. ${ }^{110}$
\end{abstract}

To complement this new world order, which was to be facilitated by a German organization of the world, Ostwald once again envisioned an international language that was both for and by science. In 1915 Ostwald proposed "Weltdeutsch", a simplified version of German, as the best option for the global transfer of information. He contended that the evitable emergence of a German driven world culture brought with it the necessity for people to learn German. ${ }^{111} \mathrm{He}$ reasonend that a common language was essential for the development of trade, science and mutually beneficial relationships between people,

\footnotetext{
108 Ostwald, Wilhelm (1915). 'Deutsche Organisation und die Wissenschaft,' Die Umschau (39), September $25^{\text {th }}$, pp. 764-766. p. 766. Archiv der Berlin-Brandenburgischen Akademie der Wissenschaften, nr. 5845/1 109 Ibid. p. 764. 
ensuring their survival and prosperity. "Weltdeutsch", he reasonend, was an ideal candidate for this task because it would contribute to the development of its users across the world by providing them with access to the treasures of German science and technology. But the point is that both Ido and "Weltdeutsch" were supposed to benefit the Germans especially by facilitating the expansion of their scientific and cultural dominance in the world. As such, their promotion by Ostwald was ultimately an expression of his dream of constructing a German Empire by expanding towards the southeast. In doing so, his goal was nothing less than the realisation of the largest coherent complex on the surface of the earth:

Der Durchbruch unserer vereinten Armeen unter tatkräftiger und von glänzender Tapferkeit getragener Mitwirkung unserer neuen Verbündeten, des bulgarischen Volkes, nach der Türkei, ist nur des kriegerische Vorspiel zu einem friedlichen Vertringen Deutschlands nach Südesten, durch welches der grösste zusammenhängende Komplex des Festlandes auf der Erdoberfläche, nämlich das europäisch-asiatische Landgebiet in eine neue Epoche seiner Geschichte und damit der gesamten Weltgeschichte eintreten wird. ${ }^{112}$

${ }^{112}$ Ibid. 


\section{CHAPTER 4}

The socially responsible engineer: Frederick G. Cottrell's pursuit of
international Language

In 1901 a young American student might well have had his first encounter with international language at one of Ostwald's student Sunday gatherings. His name was Frederick Gardiner Cottrell (1877-1948). After graduating from the University of California, he had briefly taught chemistry at a high school before travelling to Europe to continue his education. In Germany Cottrell studied physical chemistry for one semester at the University of Berlin under Van 't Hoff, after which he moved to Leipzig to work with Ostwald. In 1902 Cottrell earned his PhD there under Ostwald's guidance. By that year Ostwald was already an international language enthusiast. It is therefore more than likely that he introduced his international students to the promises of Esperanto or Volapük during one of his Sunday gatherings.

But it wasn't until 1914 that Cottrell became an enthusiastic international language proponent. In that year his interest in international languages was allegedly triggered during a brief encounter with a fellow engineer in a hotel in San Francisco. According to Cottrell's biographer, Frank Cameron, Cottrell stumbled upon an engineer who was reading an Esperanto pamphlet in the lobby. Cottrell apparently thought it was bad Italian before 
the engineer explained that it was Esperanto and added that it had helped him on several occasions to communicate with European colleagues. ${ }^{1}$ From that moment onwards Cottrell began to attend Esperanto gatherings in numerous cities in the U.S.

In 1919 Cottrell got his first chance to publicly present his ideas on international language as the chair of a Committee on International Auxiliairy Language (CIAL) of the International Research Council (IRC). Cottrell presented it as a neutral platform on which the international language subject could be studied objectively, or, to quote Cottrell, "to secure the serious study of the subject (of international language) by educational authorities and institutions throughout the world in close cooperation with commercial, technical, scientific, travel, religious, and other groups who would have most direct need for such a medium of communication". ${ }^{2}$

The CIAL was disbanded in 1924, but to continue the investigation and promotion of an artificial international language, in that same year Cottrell founded a non-profit organization called the International Auxiliairy Language Association (IALA) together with the wealthy American couple Dave Hennen Morris (1872-1944) and Alice Vanderbilt Morris (1874-1950). Until it ceased to exist in 1953, the IALA was a major supporter of American linguistics with the aim of studying and comparing artificial languages, including Esperanto and Ido, on a scientific basis.

Unlike Couturat and Ostwald, Cottrell never presented the world with a scientifically enhanced artificial language. But he shared with them the ideal of international national language that was a product of scientific research and therefore a cutting edge tool for the smooth transfer of knowledge and information on an international level. As such, Cottrell also shared with Ostwald and Couturat that he intended to mobilize his scientifically enhanced language against national antagonisms, in that it was supposed to facilitate international cooperation between scientists and politicians.

Who was Cottrell? Today he is chiefly remembered as the inventor of a device called the electrostatic precipitator, which is more commonly known as a "Cottrell". The device filters dust and smoke particles from gases through electric charges. This technology was not new when Cottrell presented it to the world. But he was the first to commercialize when he applyied for a patent on it. Cottrell also broke new ground by establishing the Research Corporation (RC) to manage his patents with the aim of using the revenue for the promotion and funding of scientific research. As an independent and non-profit foundation dedicated to the promotion of scientific research, the RC was the first of its kind. From 1920 onwards it funded numerous projects, including Robert H. Goddard's early work on the liquid-fueled rocket, Ernest Lawrence's development of the famous cyclotron, and production methods for vitamins A and B1.

Cottrell continued to remain loosely involved in the activities of the RC as a scout for

\footnotetext{
${ }^{1}$ Cameron, Frank (2004[1952]). Cottrell: Samaritan of Science. Tuscon, Ariz: Research Corporation.

${ }^{2}$ Cottrell, Frederick G. (1923). Report of Progress, August 1923. Committee on International Auxiliary Language of the International Research Council, p. 6.
} 
promising research projects, but he spent most of his professional career as a servant of the state. In 1911 Cottrell joined the United Stated Bureau of Mines until 1920, holding the positions of chief physical chemist on field duty, chief chemist, chief metallurgist, assistant director, and finally director. In 1921 Cottrell left the Bureau of Mines to chair the Chemical Technology Division of the National Research Council. One year later he was appointed as the head of the fixed Nitrogen Research Laboratory of the U.S. Department of Agriculture. He held this position until 1930. In the 1930s he continued to work as an independent consult for the RC. Between 1935 and 1938 Cottrell was president of an enterprise called Research Associates. Like the RC, its aim was to carry inventions into the development and application process. ${ }^{3}$ Its projects included detergents, heat wave roasting, deodorizers and Royster stoves.

Cottrell's involvement with international language was one of many activities in a long and successful scientific career. He was not only awarded numerous medals for his scientific and his organizational work. ${ }^{4} \mathrm{He}$ was also a member of several societies, including the National Academy of Science, the American Chemical Society, the American Electrochemical Society, and the National Institute of Mining and Engineers. Unsurprisingly, professional acknowledgement for his involvement with international language never came. In fact, Frank Cameron points out that his scientific peers generally tended to classify it as a product of his eccentric peronality:

The foibles of Cottrell had long been considered as something apart from his scientific work and where thought of as adding much charm and color of his personality. Included here were his glasses; the dilapidated condition of the automobiles he successively owned; the frightening way in which he drove them, subordinating all operating procedure to the demands of conversation; the pony truck; his pride in catching trains within sixty seconds of scheduled departure; the international language; his unfailing kindness to everyone including one or two who violated all recognized all codes of decency in taking advantage of his generosity; his disregard of orthodox meal hours; his capacity for outraging gourmet's sensibilities (...). ${ }^{5}$

Cottrell's involvement with international language might well have been an expression of his eccentric personality. In what follows it will become clear, however, that it did not stand

\footnotetext{
${ }^{3}$ Bush, Vannevar (1949). 'Frederick Gardner Cottrell: 1877-1948,' Science (110)2863: pp. 497-498. p. 498.

${ }^{4}$ Cottrell received the Perkin Medal, the Willard Gibbs Medal of the Chicago Section of the American Chemical Society, the Medal of the Mining and Metallurgical Society, the Washington Award of the Washington Chemical Society, the Holly Medal of the American Society of Mechanical Engineers, and the Medal of the American Institute of Chemists.

${ }^{5}$ Cameron (nr. 1), Cottrell: Samaritan of Science, p. 367.
} 
"apart from his scientific work". In fact, it is shown that the opposite was the case. For it is argued that Cottrell's involvement with international language was driven by a distinct and cohesive ideological agenda that was an expression of the scientific and political context in which he operated.

But before we take a closer look at the contours of this ideological program, the first section of this chapter will reseet the stage by providing a brief account of international and national language politics during and after World War I. In the second half Cottrell's position on international language is introduced in this broader context. Section 2 offers a short description of where and how Cottrell developed his passion for the international language subject. Section 3 takes a closer look at the world in which he operated. Just like Couturat and Ostwald, Cottrell lived in a world that appeared to be shrinking through the advancement of science and technology. But this was only one of several more specific and individual components of his ideological program. Section 4 argues that one of these components was an American turn-of-the-century notion of science and engineering as a social experiment. Section 5 identifies another component in the form of distinct turn-ofthe-century status enhancement politics by American engineers. Not surprisingly, Cottrell's promotion of international language was also a product of national politics. Section 6 will argue that it was an expression of the post-World War I American expansionist program under president Woodrow Wilson (1856-1942).

From 1921 onwards, Cottrell became less active as promoter of a scientific international language, but in that year he founded and continued to fund the IALA together with Alice Morris Vanderbilt. Section 8 argues that its activities to promote and conduct a scientific approach of the international language subject was a joined product of Cottrell's ideological program and Vanderbilt's philanthropy, which was a typically earlytwentieth-century strategy of wealthy Americans to enhance their social position. In 1951 the IALA eventually produced a new and scientifically forged international language called Interlingua. By then Cottrell and Vanderbilt were no longer alive. Interlingua was a product of the efforts of several American linguists. The last section argues they became involved in the IALA as expression of their political quest to upgrade linguistics by showing that it was a serious scientific discipline.

\subsection{From prewar to postwar language politics}

The promotion of Ido by representatives from the scientific community temporarily came to a halt after Couturat's death in 1914 and Ostwald's conversion to "Weltdeutsch" in 1915. But Ido continued to enjoy the support of Ido's co-creator and president of the French Ido society Louis de Beaufront. Several pamphlets that promoted Ido were published under his name. We saw that before the war Couturat and Ostwald presented Ido as a means to dissolve wars. De Beaufront attempted to sell Ido at the warfront by presenting it as an 
instrument that facilitated communication between the allied forces and nurses at the front. In fact, for de Beaufront Ido's target audience even included the wounded and sick. The title of his 1917 Ido guide read: Ido-Guide (English-Ido) for Doctors, Nurses, StretcherBearers, The Wounded, The Sick, Soldiers. ${ }^{6}$

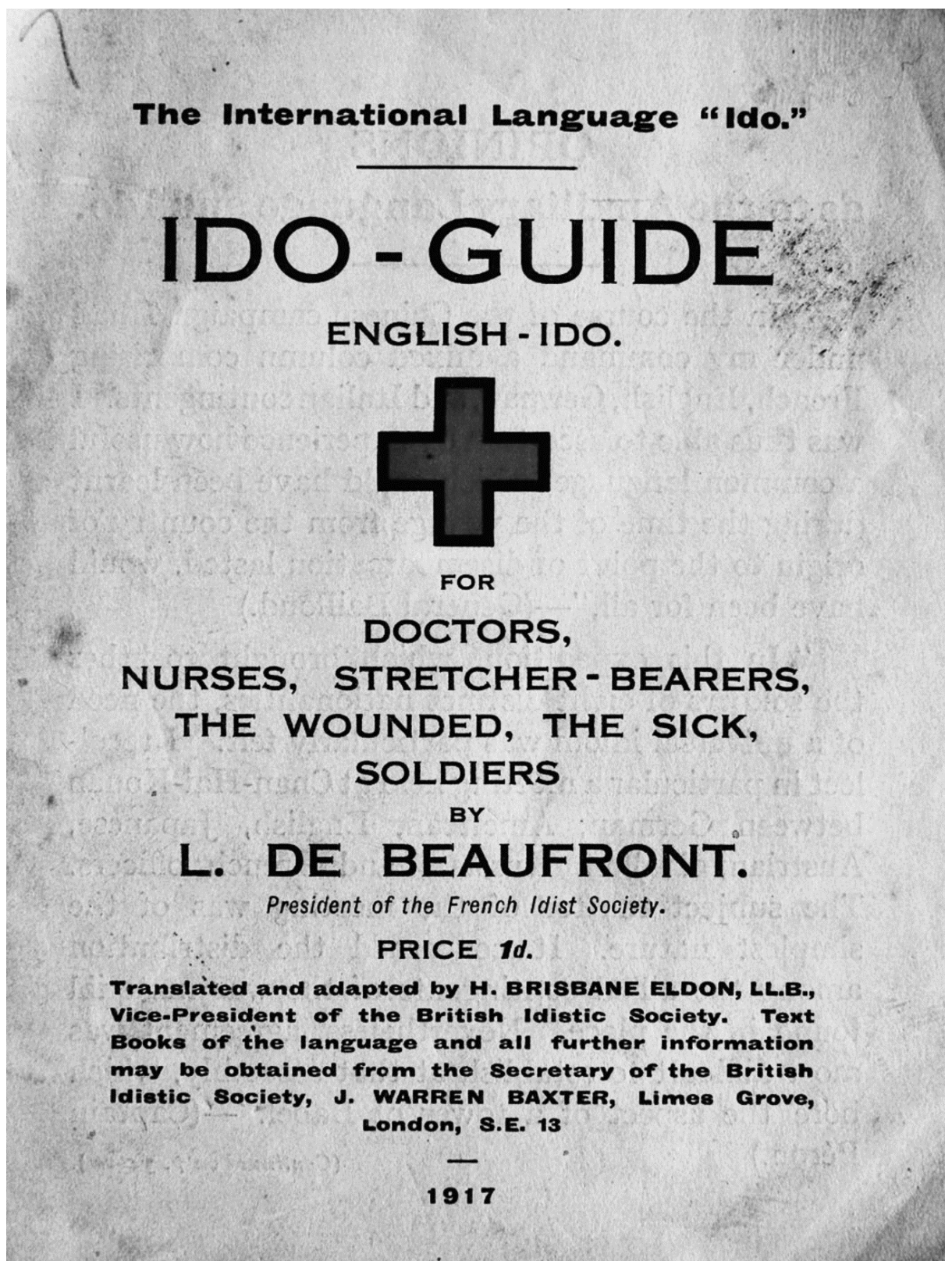

A photograph of the cover of Louis de Beaufront's 1917 IdoEnglish guide for "doctors, stretcherbearers, the wounded, the sick, soldiers".

\footnotetext{
${ }^{6}$ de Beaufront, Louis (1917). Ido-Guide (English-Ido) for Doctors, Nurses, Stretcher-Bearers, The Wounded, The Sick, Soldiers. Translated and adapted by H. Brisbane Eldon, president of the British Idistic Society. London: Blades, East \& Blades printers.
} 
Ido regained some momentum after the war when the Swedish linguist Otto Jespersen joined de Beaufront to promote it. Their attempts were mentioned in the 1921 issue of Nature. It reported on two papers by Jesperson on "International Language in English and Ido" and a pamphlet by de Beaufront on "The Auxiliairy Language Ido" about "the origin of Ido as a development from Esperanto, and the claim that it is free from many defects to be found in the earlier artificial language". ${ }^{7}$ The Esperantists also returned in force, because the political climate in Europe seemed favorable for the adoption of an international language.

The formation of the League of Nations in 1918 marked a new American dominance in the international political landscape. To ensure a stable and prosperous Europe, Woodrow Wilson, the League's designer, propagated a new world order with an emphasis on collective security, democracy and self-determination as opposed to traditional European power politics. One of the main goals of the League was to maintain world peace by preventing war through collective security and disarmament and by settling international disputes through negotiation and arbitration. This postwar institutionalization of U.S. and Allied driven internationalism, which dictated collaboration and rational arbitration between European nations, conveniently fit the aspirations of international language proponents.

In 1921 Esperanto was proposed to the General Assembly of the League of Nations by Nitobe Inazō (1862-1933), a Japanese diplomat and politician. ${ }^{8}$ Nitobe, who is labeled by Akira Iriye as Japan's foremost internationalist, ${ }^{9}$ was a founding director of the International Committee on Intellectual Cooperation (later UNESCO). More recent scholarship, especially by the historian Thomas Burkman, emphasizes that Nitobe's internationalism was driven by a strong sense of nationalism and imperialism. ${ }^{10}$ Nitobe proposed the League to adopt Esperanto as its working language. ${ }^{11}$ His report was based on his participation in the $13^{\text {th }}$ World Congress of Esperanto in Prague in August 1921 as one of two delegates of the League - the report refers to the other delegate as " $\mathrm{Mr}$.

\footnotetext{
7 (1921). 'News: University and Educational Intelligence,' Nature (108)2716: p. 386.

${ }^{8}$ Nitobe, Inazo (1921). 'Esperanto and the Language Question at the League of Nations,' Report submitted to the Secretary-General of the League of Nations on August $11^{\text {th }}, 1921$. p. 5. Retrieved from the World Wide Web on March $12^{\text {th }}, 2011$ :

http://www.google.nl/url?sa=t\&rct=j\&q=\&esrc=s\&source=web\&cd=1\&ved=0CCsQFjAA\&url=http\%3A\%2F\%2F nitobe.info\%2Fld\%2Fdokumentujo\%2Fdokumentoj\%2Fnc_dokumento-18-

enkonduko3_en.pdf\&ei=fHmvUJuDLJO2hAe184HgBA\&usg=AFQjCNH2ZkWHPglePXOaWX5XqIWJo6R7sg\&sig2 =1JCA8MeClemG2-RjGzscfA

${ }^{9}$ Iriye, Akira (1997). Cultural Internationalism and World Order. Baltimore, M: John Hopkins University Press. p. 44.

${ }^{10}$ Burkman, Thomas W. (2008). Japan and the League of Nations: Empire and World Order, 1914-1938. Honolulu, HI: University of Hawaii Press.

${ }^{11}$ For an excellent account on the history of Esperanto in Japan and China, see, Lins, Ulrich (2008). 'Esperanto as language and idea in China and Japan,' Language Problems \& Language Planning (32)1: pp. 47-60.
} 
Fujisawa", "being about the only Esperantist in the Secretariat". ${ }^{12}$

Ten delegates accepted Nitobe's proposal. But the French delegate vetoed the proposal - unfortunately enough for the Esperantists. It was nonetheless an important moment in the eyes of Esperantists. Esperanto was finally awarded some official acclaim by an authoritative international governmental institution. The Idists also invited the League the join their Ido congress in Vienna, which was scheduled to take place in the following week. Nitobe did not attend the congress, but his proposal upheld the League's neutrality: "The League of Nations does not, of course, take sides with either, nor will it exert itself in mediating between them as the war of tongues lies outside the pale of its aims to avert!" ${ }^{\prime 13}$

The postwar politics in Western Europe not only involved a sudden U.S. and allied driven impulse towards rational international collaboration. The League of Nations' brief association with Esperanto and the fact that its creator was Jewish led Adolf Hitler (18891945) to publicly denounce it as a Jewish language for world domination. ${ }^{14}$ Hitler repeated his position on Esperanto in Mein Kampf: "Solange der Jude nicht der Herr der anderen Völker geworden ist, muß er wohl oder übel deren Sprachen sprechen, sobald diese jedoch seine Knechte wären, hätten sie alle eine Universalsprache (z.B. Esperanto!) zu lernen, so daß auch durch dieses Mittel das Judentum sie leichter beherrschen könnte!". ${ }^{15}$

Hitler's loathing of Esperanto was serious. As he rose to power Esperanto organizations were banned in Germany and during World War II Esperantists were either sent to labor camps or exterminated. The only possible world language was, of course, German. Resonating Ostwald's promotion of "Weltdeutsch", Franz Thierfelder (1896-1963), a conservative general secretary of Die Deutsche Akademie, promoted German as international language towards the Balkan countries with books like Das Deutschtum im Auland (1934), Deutsch als Weltsprache (1938), and Der Balkan als politischen Kraftfeld (1940). ${ }^{16}$

In the Anglo-Saxon community there was also a brief interest in the idea of an international language in the form of a simplified English called Basic English. It was created and promoted by two British scholars, the Cambridge linguist and philosopher C.K. Ogden (1889-1759) and the Harvard literary critic Ira A. Richards (1878-1979). In the 1920s they began experimenting with the possibilities of reducing the number of words of English with the idea of making it easier to learn for non-native speakers. After nearly ten years of experimenting they choose 850 words as the vocabulary of Basic English. Their idea was that these words could fit on a single piece of paper together with a few basic grammatical

\footnotetext{
${ }^{12}$ For more reading on Nitobe as internationalist and its national roots, see, Howes, John F. (ed.) (1995). Nitobe Inazō: Japan's Bridge Across the Pacific. Boulder, CO: Westview.

${ }^{13}$ Inazō (nr. 8), 'Esperanto and the Language Question at the League of Nations,' p. 5.

${ }^{14}$ Sutton, Geoffrey H. (2008). Concise Encyclopedia of the Orginal Literature of Esperanto: 1887-2007. New York: Mondial Publishing. p. 161.

${ }^{15}$ Hitler, Adolf (1943[1925]). Mein Kampf. München: Franz Eher Nachf. Verlag (Zentralverlag der NSDAP). p. 337.

${ }^{16}$ Michels, Eckard (2004). 'Deutsch als Weltsprache? Franz Thierfelder, the Deutsche Akademie in Munich and the Promotion of the German Langauge Abroad, 1923-1945,' German History (22)2: pp. 206-228.
} 
rules, making it cheaper and easier to circulate. ${ }^{17}$ Ogden managed to get financial support for Basic English from the Rockefeller Foundation. Richards, who accepted a visiting professorship at Tsing Hua University in Peking in 1929, also managed to extend Rockefeller's financial support for research on the possibilities of adapting Basic English to Eastern languages. ${ }^{18}$

Basic English never attained a large following. But it inspired the work of renowned British authors H.G. Wells (1866-1946) and George Orwell (1903-1950). Wells' 1933 novel The Shape of Things to Come (1933) introduced Basic English as a literary vehicle that facilitated the emergence of a unified world under the guidance of a benevolent dictatorship. Like Ostwald's internationalist program, Wells' fiction had strong imperialist undertones, because in his story Islamism disappears completely as Basic English replaces Arabic. Orwell had concrete and urgent hopes for it during World War II. Between 1942 and 1944 he presented Basic English as means for the Allies to communicate more efficiently. But he soon became critical of Basic English. In his Nineteen Eighty-Four (1949) Orwell caricatured it as "Newspeak", a form of simplified English that was promoted by the totalitarian state in an attempt to thwart any form of alternative thinking.

At one point Winston Churchill (1874-1965) also expressed his support for Basic English. He did so during a Harvard speech in 1943 in which he fired up his Anglo-Saxon audience with the promise of victory over the Nazi's. Churchill turned with hopeful eyes towards the future by calling Basic English "a carefully wrought plan for transactions of practical business and interchange of ideas, a medium of understanding to many races and an aid to the building of a new structure for preserving peace" ${ }^{19}$

The scientific community did not stay behind in becoming engaged in international and national language politics in the interbellum when in 1919 the IRC installed Cottrell as the chairman of its CIAL. In this function Cottrell advocated the need of a scientific tool in the form of an international language to facilitate international cooperation between scientists. He claimed that this was a necessary step, because scientific cooperation was a means of relegating national misunderstandings to the past. In a 1919 speech Cottrell argued that: "If international cooperation in science can be made effective in both the pure and applied branches it will unquestionably furnish one of the most powerful forces possible against the growth of national misunderstandings." 20

\footnotetext{
${ }^{17}$ (1943). 'Richards of Harvard Creates Basic English. System Mentioned in Churchill Talk,' The Harvard Crimson. September, $10 t^{h}$. Retrieved from the Worldwide Web on January 10th, 2012: http://www.thecrimson.com/article/1943/9/10/richards-of-harvard-creates-basic-english/

${ }^{18}$ Koeneke, Rodney B. (2004). Empires of the Mind: I. A. Richards and Basic English in China, 1929-1979. Stanford, CA: Stanford University Press. p. 94.

${ }^{19}$ Churchill, Winston (1943). 'The Price of Greatness is Responsibility,' Harvard speech given at the occasion of receiving an honorary Doctor of Laws degree. Available on the website of The Churchill Centre and Museum at the Churchill War Rooms, London. Retrieved from the World Wide Web on September, $10^{\text {th }}, 2012$ : http://www.winstonchurchill.org/index.php?option=com_content\&view=article\&id=420\&ltemid=32

${ }^{20}$ Cottrell, Frederick G. (1920). 'Willard Gibbs Medal Award: Medal Address International Scientific Relations,' The Journal of Industrial and Engineering Chemistry (12)7: pp. 679-700. p. 698.
} 
Cottrell's mission was to facilitate the scientific study of the international language question objectively and neutrally to develop such an instrument. He argued that the CIAL could provide a platform for the scientific study and experimentation on artificial languages. To highlight the urgency of the CIAL's mission he claimed that there was a clear and widespread interest in "other institutions of learning through the world" in the principle of an international language. He added that in other domains the demand for proper research on the subject of international languages was just as real. To back this claim up Cottrell referred to the League's brief involvement with Esperanto: "Probably the most significant indication of the rapidity of the growing demand in this direction is the official recognition given to the problem by the League of Nations" ${ }^{21}$ Cottrell emphasized the League's interest in Esperanto, claiming that it showed the urgency of conducting proper, scientific research concerning the subject of international languages.

How exactly did Cottrell envision his ideal international language? He complained of a tendency at universities and research institutions to view language as something that could not be subjected to scientific experimentalism. He argued that experts falsely assumed that because existing languages were a product of many generations that it would be useless and even disrespectful to parallel this process through scientific experimentation:

In the face of our efforts spent on the development of these material aids to human communication and the splendid results achieved we can hardly do otherwise then stand aghast when we consider that in all the world's universities and research institutions language itself is still looked upon purely from a historical aspect as something handed down from antiquity and that even to parallel it experimentally with scientifically constructed systems of our own devising is considered a foolish waste of time not to say downright sacrilegious. ${ }^{22}$

Needless to say that Cottrell strongly disagreed with the view that it was futile to construct a language through scientific experimentation. He claimed that language was essentially a technological tool and as such it could be adjusted, disassembled and reassembled to make it more efficient and more neutral for its users. Like Couturat and Ostwald, Cottrell contended that these qualities made a scientific international language better for communicating across national boundaries than any existing language. He claimed that the advantage of performing scientific experiments on languages was that it could lead to a language that was free from the very historical ballast (which he equated with nationalism)

\footnotetext{
${ }^{21}$ Cottrell (nr. 2), Report of Progress, August 1923. Committee on International Auxiliary Language of the International Research Council, p. 3.

${ }^{22}$ Ibid.
} 
that lead his contemporaries to falsely assume that language was above science.

Cottrell also argued, however, that the eventual adoption of a scientific international language as an international standard for communication did not make national languages superfluous. For it was simply a different tool than national languages, in that it's specific function was to provide a linguistic shortcut between nations, not within them. Cottrell compared this situation to the relation between national languages and stenography: "The project of an auxiliairy language may be looked upon as analogous to that of stenography, i.e., as a development of a special tool for special purposes, which has no more bearing on the use and spread of existing national languages than stenography has had on that of printing on the long hand". ${ }^{23}$ Cottrell's emphasis on the role of the international languages as a second language also clarifies why he referred to it as "auxiliary", which literally means additional or supplementary. ${ }^{24}$

\subsection{Cottrell becomes international language proponent}

Cottrell claimed that he had no preference for either Ido or Esperanto, but he became a passionate international language proponent in the American Esperanto community. Zamenhof published his first basic introduction to Esperanto in Warsaw in 1887. Before spreading to Western Europe the Esperanto movement initially grew in Eastern Europe and the Russian empire. It spread to Canada in 1901, and three years later it spread to Chile, Japan and Peru. In 1905 the first Esperanto club, called the Amerika Esperantista Asocio, was founded in Boston. Two years later a North American Esperanto-language publication, called Amerika Esperantista Revuo, was founded. Another journal was founded in the same period, which was initially called the Amerika Esperantisto but was later renamed as Esperantista Asocio de Norda Ameriko.

Spurred on by the foundation of these Esperanto journals, various local Esperanto societies emerged in cities across the U.S., including Washington, which hosted the first world congress in the U.S. in 1910, and San Francisco, which hosted the 1915 world congress. The San Francisco congress hosted 165 American and Canadian Esperantists, making it the smallest World Esperanto Congress ever held. It was hosted in the U.S. because Europe was in the grip of World War I. Its attendance rate contrasted strongly with that of the same events in Europe. ${ }^{25}$ The first World Congress in 1905 in Boulougne-surMer in France hosted 688 people. Since then it became a yearly event, with the number of participants steadily rising. The same events in Dresden and Barcelona in 1908 and 1909

\footnotetext{
23 Ibid. p. 2

24 'Auxiliary,' Definition and More from the Free Merrian-Webster Dictionary. Retrieved from the World Wide Web on October 10th, 2012: http://www.merriam-webster.com/dictionary/auxiliary

${ }^{25}$ Matthias, Ulrich (2002). Esperanto: the New Latin for the Church and for Ecumenism. Translated from Esperanto by Mike Leon and Maire Mullarney. Antwerp: Flandra Esperanto-Ligo. p. 47.
} 
both hosted 1500 participants.

Despite the small size of the American Esperanto community Cottrell was an eager and frequent attendee of Esperanto gatherings across the U.S. This was facilitated by his work for the Bureau of Mines. He was based in San Francisco, but his job for the bureau took him across the country to inspect mines, smelter plants, and safety regulations of industrial sites, which required him to travel frequently across the U.S. to inspect the safety of mines. ${ }^{26}$ The bureau's mission was "to increase health, safety, economy, and efficiency in the mining, quarrying, metallurgical, and miscellaneous mineral industries in the country". ${ }^{27}$

Cottrell would remain an enthusiastic visitor of Esperanto gatherings throughout his involvement with international language. But by about 1916 he developed the conviction that a proper approach to the international language subject was a scientific one. To walk this path he sought the support of scientific organizations that could provide the prestige and funding for a thorough investigation of the international language subject. The first institutions Cottrell contacted were the American Association for the Advancement of Science (AAAS) and the Smithsonian Institution. Unfortunately for Cottrell, both institutions refused to support his cause.

But despite the Smithsonian's refusal to support his cause, Cottrell initially had reasons to be hopeful about gaining its support. In 1911 the Smithsonian's secretary, the famous paleontologist Charles Doolittle Walcott (1850-1927), embraced Cottrell's plans to establish a non-profit organization for the management of his patents. In fact, Walcott proposed the idea of establishing the RC and he played an advisory role in overseeing the patenting and licensing involved in its founding. ${ }^{28}$ Seven years later Cottrell called upon Walcott again in an attempt to convince him that the Smithsonian should take up the task of compiling, exploring and making available to the public the issue of an artificial international language.

Cottrell presented Walcott with a brief history of Esperanto and Ido, arguing that there seemed to be an "increased interest and activity" in relation to the two languages. ${ }^{29}$ He suggested that "as a working project" Esperanto "would best fulfill its maximum of usefulness in the general cause of international language through a minimum of fundamental changes" on the grounds that it had the most followers. ${ }^{30}$ But he also defended Ido by arguing that it had "performed a valuable function as an experimental proving ground of linguistic questions, and thus has accumulated a very considerable mass

\footnotetext{
${ }^{26}$ Cameron (nr. 1), Cottrell: Samaritan of Science, $\mathrm{p} 178$.

${ }^{27}$ Cited in, Cornell, Thomas D. (2004). Establishing Research Corporation. A Case Study of Patents, Philanthropy, and Organized Research in Early 20th Century America. Tucson, Arizona: Research Corporation. p. 59

${ }^{28}$ Mowery, David \& Nelson, Richard \& Sampat Bhaven \& Ziedonis, Arvids (2004). Ivory Tower and Industrial Innovation: University-Industry Technology. Stanford, CA: Stanford University Press. p. 60.

${ }^{29}$ Frederick Cottrell to Derek Walcott, March 29, 1918. Archive of the Research Corporation. Box 7, F. 82. ${ }^{30}$ Ibid.
} 
of data and discussion which should prove invaluable in the working out of the final solution, irrespective of which of the two present main projects this may most nearly resemble". ${ }^{31}$

Cottrell explained to Walcott that past attempts to select an international language were carried out by "self-constituted propaganda societies, representing individual language projects". ${ }^{32}$ He argued that it was necessary to organize a thorough and objective research program to break with this tradition, because only this would ensure the selection of an international language that would practically and objectively be the best choice. Cottrell suggested that the Smithsonian "could perform a particularly appropriate and important service by acting as connecting link to bring this really vast but now scattered amount of important material (...) to a focus and make these actually available to the educational and other Governmental agencies". ${ }^{33}$ The necessary step was to establish a neutral platform on which various international language projects could be studied and evaluated. Cottrell also suggested the Smithsonian to appoint a research supervisor for this task who was to be chosen with "considerable care" to ensure that he/she was "as free as possible from partisan view as between rival projects". ${ }^{34}$

\subsection{A shrinking world}

Cottrell argued that the adoption of a scientifically enhanced international language was a logical step in the process of globalization, which was already set in motion by the material advances of science and technology: "Land, water and aerial transportation, printing and the postal service, the telegraph, cable, telephone and finally radio have made world communication not only swift, easy and practicable, but the dominant factor of the age". ${ }^{35}$ He concluded that an era dominated by a swift international communication needed an appropriate language to further facilitate this process of globalization. Cottrell's conception of a world that was knitting up though the material advancements of science and technology strongly echoed one of the central messages of the 1915 Panama-Pacific International Exposition in San Francisco.

As pointed out, Cottrell was rarely in San Francisco because of his work for the Bureau of Mines. But 1915 was an exception because the Bureau exhibited at the San Francisco World's fair, requiring him to stay in San Francisco. Like every World's fair the San Francisco fairgrounds offered a spectacular showcasing of national achievements in the

\footnotetext{
31 Ibid.

32 Ibid.

33 Ibid.

${ }^{34}$ Ibid. p. 4

${ }^{35}$ Cottrell (nr. 2), Report of Progress, August 1923. Committee on International Auxiliary Language of the International Research Council, p. 1.
} 
field of science and engineering. The Bureau exhibited in a separate building called the Palace of Mines and Metallurgy, where illustrations of mining and metallurgical processes were proudly displayed.

Besides taking a keen interest in the fair in his capacity as chief of mining and metallurgy, Cottrell took part in the pompous displays of engineering might by initiating a theatrical public showing of the principles his electronic precipitator. His plan was to dissipate the famous San Francisco fog. ${ }^{36}$ To do this, he placed a system of horizontal electrodes that were connected to a 350,000 volt transformer on the roof of the Palace of Machinery. Despite several months of testing, adjusting, and retesting, the device never caused any visible dissipation of the fog. Other examples of engineering might on display at the fair included the first transcontinental phone call to the fairgrounds by Alexander Graham Bell (1847-1922) and a full-scale Ford assembly line at the Palace of Transportation that produced a car every 10 minutes.

But the fair was organized to celebrate the freshly dug Panama Canal, which was officially opened in 1914. The centerpiece of the fairgrounds was a reproduction of the manmade canal that covered five acres to give the visitors a sense of the sheer magnitude of the project. The largest manmade structure ever built, the U.S. government had spent $\$ 375,000,000$ (today it would amount to a staggering $\$ 8,600,000,000$ ) to create it. ${ }^{37}$ The canal radically cut travel time and freight costs, shortening the distances between the East Coast and the markets in the west. This journey previously lasted 60 days, now it lasted only 30 days.

The replica of the Panama Canal was a celebration of the seemingly limitless capabilities of modern engineering. The Panama-Pacific exposition's visitors guide reminding its readers that: "The Panama-Pacific International Exposition, itself an achievement of overwhelming grandeur, will celebrate the completion of the Panama Canal - man's most audacious correction of Nature's work in his greatest triumph over unfriendly forces". ${ }^{38}$ This emphasis on America's formidable engineering capacities marked a contrast with the propensity at previous fairs to present a kaleidoscope of the world's cultures as the central spectacle. The San Francisco fair was distinctive, in that natural phenomena were ingeniously mimicked by technological means on the fairgrounds. But the San Francisco fair shared with previous World's fairs that its celebration of technology went hand-in-hand with sending out the message that the world was shrinking through rapid advances in communication and transportation technologies. The imposing replica of

\footnotetext{
${ }^{36}$ Cameron (nr. 1), Cottrell: Samaritan of Science, p. 180.

${ }^{37}$ The French initiated the canal in 1880, but the costs and difficulties of the project led it to go bankrupt in 1890. The project came under American control after the government bought the approval of the French as well as the Panama railroad in 1904. It also signed a treaty with Panama that established their control over the Panama Canal Zone.

${ }^{38}$ (1915). Information for the Visitors to the Panama-Pacific International Exposition. San Francisco, 1915. Retrieved from the Worldwide Web on January 8th, 2012: http://www.books-aboutcalifornia.com/Pages/Info_for_Visitors_PPIE/Info_for_Visitor_PPIE_text.html
} 
Panama Canal and the theatrical staging of the first transcontinental phone call were meant to give the spectators a glimpse at the globalized world that was lying ahead.

The San Francisco fair not only celebrated humanity's power over nature. It also promoted the positive effects of technology on the nature of humanity. With World War I escalating in Europe it was hoped that the improved transportation and communication made possible by the Panama Canal as well as the telephone would relegate war to the past by forging partnerships between nations worldwide. It was hoped that in doing so it would bring the east and the west closer together on an economical and cultural level. To cite an American reporter:

\begin{abstract}
Just now it happens that the war in Europe makes us long for peace (...). We know that day by day distance is contracting, and that, whether we will or not, we shall soon be touching elbows with every race. (...) The PanamaPacific Exposition affords the means of knowledge of the art, science and progress of the peoples of the world. It affords an opportunity to make an honest estimate of our neighbors (...). This exposition is the first which combines the material and the altruistic. It is a new butterfly, a new orchid, a new machine, a new style, a new product. ${ }^{39}$
\end{abstract}

Cottrell's conception of the international language as a technological tool that was supposed to improve communication between nations by bringing them closer together was a typical expression of the same techno-optimism that was celebrated at the San Francisco fair. His claim that a techno-scientific approach to language was needed to forge a linguistic shortcut that was meant to shrink the economical and cultural distance between nations closely resembled of Couturat's and Ostwald's claims. But like Couturat and Ostwald, Cottrell's scientific linguistic internationalism was more driven by an individual ideological program than that it was pulled by a general demand for his project - he failed to gain support for his plans to establish a scientific platform for the investigation of the international language subject. The next sections describe the components of Cottrell's ideological program.

\title{
4.4 Science as social experiment
}

The first component of the ideological program that propelled Cottrell to promote international language was his conception of science as a social experiment. In this section

\footnotetext{
${ }^{39}$ Cited in, Tenkotte, Paul A. (1987). 'Kaleidoscopes of the World: International Exhibitions and the Concept of Culture-Place, 1851-1915,' American Studies (28)1: pp. 5-29. p. 26-27.
} 
we will see that this tendency was a product of a political movement called Progressivism, a dominant political movement in America that emerged at the end of the nineteenth century and that continued to dominate American politics throughout the first half of the twentieth century.

Cottrell's calls for the need to experiment on language to create an international language were not the first time he used the language of experiment in relation to social matters. In 1912 Cottrell presented the RC as a public experiment in patent management, stating that it "was not merely to produce revenue for scientific research, but to act as a sort of laboratory of patent economics and to conduct experiments in patent administration". ${ }^{40}$ The function of the RC was to donate money generated by Cottrell's patents on the electronic precipitator to fund scientific research.

Cottrell had invented the electronic precipitator several years earlier. It was almost immediately a success because the social demand for it was high. Since the 1880s, industrial cities in the U.S. witnessed the birth of anti-smoke organizations. ${ }^{41}$ Cottrell's device, which used a simple technique of electrical charges to filter out dust from industrial smoke, was embraced by industries across the nation because it provided companies with a relatively easy and cheap means to uphold a positive public image.

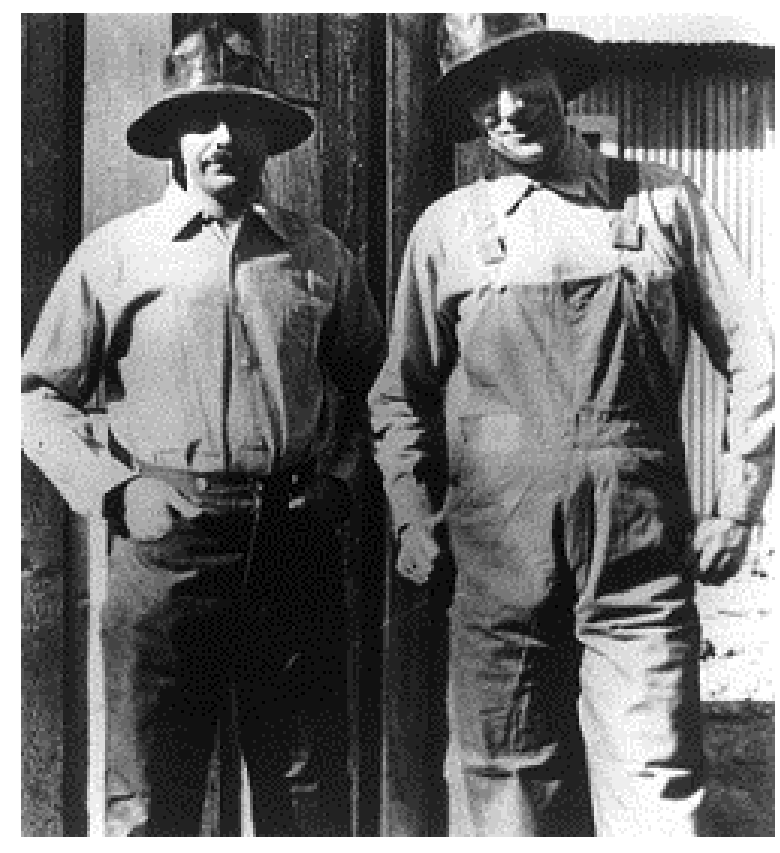

Frederick G. Cottrell (right) in 1916 with Walter A. Schmidt, president of Western Precipitation Company, which pioneered in the commercial application of Cottrell's electronic precipitator. ${ }^{42}$

${ }^{40}$ Cited in, McKusick, Vincent, L. (1948). 'A Study of Patent Policies in Educational Institutions, Giving Specific Attention to the Massachusetts Institute of Technology,' Journal of the Franklin Institute (245)4: pp. 193-270. p. 208.

${ }^{41}$ Uekötter, Frank (2009). The Age of Smoke: Environmental Policy in Germany and the United States. Pittsburg: Pittsburg University Press.

${ }^{42}$ Visual History Gallery on the official website of the Research Corporation for Science Advancement. Retrieved from the Worldwide Web March $3^{\text {rd }}, 2013$ :

http://www.chemheritage.org/discover/online-resources/chemistry-in-history/themes/public-andenvironmental-health/environmental-chemistry/cottrell.aspx 


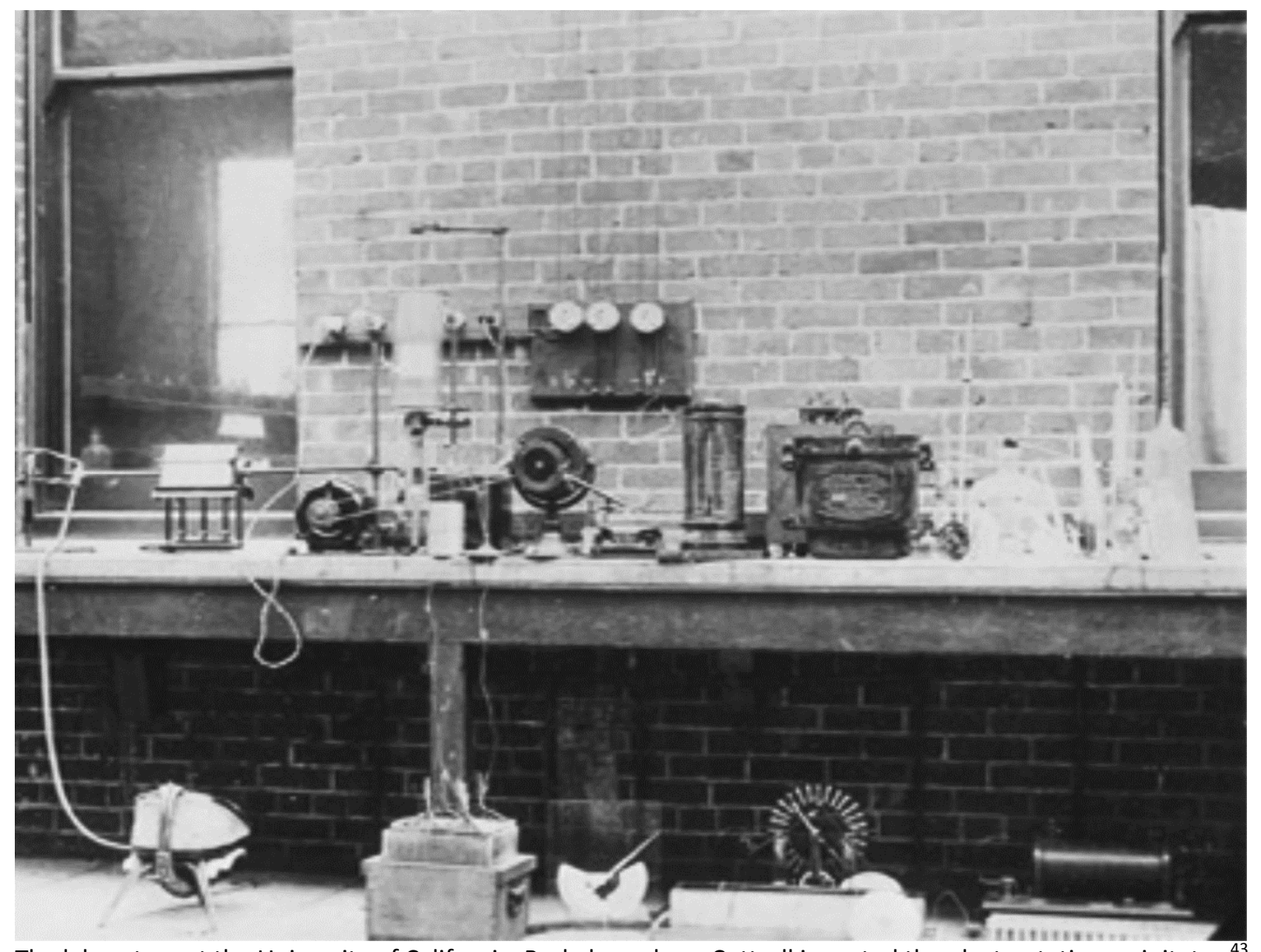

The laboratory at the University of California, Berkeley, where Cottrell invented the electrostatic precipitator. ${ }^{43}$

Cottrell first considered donating his patents on the precipitator to the U.S. Bureau of Mines. But its director, Joseph H. Holmes (1859-1915), refused the offer on the grounds that it undermined the bureau's status of disinterestedness. ${ }^{44}$ Holmes proposed the alternative option of donating the patents to the Smithsonian Institution, which declined the responsibility on the grounds that it did not have sufficient experience in patent management. But as pointed out its secretary, Charles Walcott, decided to help Cottrell to establishing his own corporation. With Walcott's help Cottrell managed to mobilize a volunteer group of fifteen "nationally recognized men" that represented science and business to form a business group that managed Cottrell's patents. ${ }^{45}$

\footnotetext{
${ }^{43}$ Visual History Gallery on the official website of the Research Corporation for Science Advancement. Retrieved from the Worldwide Web March $3^{\text {rd }}$, 2013: http://www.rescorp.org/about-rcsa/history/visualhistory-gallery

${ }^{44}$ Cornell, Thomas D. (nr. 27), Establishing Research Corporation,' p. 61.

${ }^{45}$ The members of the original Board of Directors included: William L. Dudley (Chair of chemistry at Vanderbilt University and part of the governing council for ACS); Thomas Coleman du Pont (engineer, politician and president of E.I. Du Pont de Nemours and Company explosives business); Frederick A. Goetze (Dean of the Faculty of Applied Science at Columbia); Hennen Jenning (mining engineer and consulting engineer to the Bureau of Mines); Elon Huntington (electrical engineer, deputy superintendent of Public Works of New York and State and founder of Hooker Electrochemical Comapny); Arthur D. Little (chemist, founder of world's first
} 
The RC was born in 1912 on 26 February with a starting capital of $\$ 20.000$ of which directors and others interested in the experiment paid in $\$ 10.100$ as a loan. Highlighting the pioneering character of the RC, in 1937 Cottrell recalled the following reaction to the $\mathrm{RC}$ by one of its early sponsors: "Your project of a non-profit business corporation strikes me as too bizarre and self-contradictory to succeed, but if these busy and successful business men you have secured as directors are willing to give their time and effort to the experiment, they can count on me for a thousand dollars toward trying it out" ${ }^{46}$

Cottrell made clear that the aim of this pioneering experiment in patent administration was to facilitate closer cooperation between universities and technical schools on the one hand and industrial plants on the other:

During the last few years, the rapid growth of engineering and technical education, coupled with a general awakening to the commercial importance of research in the industries, has brought about a persistent demand the world over for closer and more effective cooperation between the universities and technical schools on the one hand and the actual industrial plants on the other. The value to both sides from such an operation is today generally conceded, but as to the most expedient methods of its accomplishment opinions differ, and we are still in the experimental stage of working out the problems. ${ }^{47}$

Cottrell furthermore claimed that new forms of science and technology management were needed to minimize the influence of commercial interests on scientific research at universities and technical schools to prevent the development of profit driven competition between research institutions. Cottrell pointed out that this was an undesirable development because it led institutions to become islands where scientific secrecy was favored over openness and collaboration.

The RC, then, was meant to harness this "growing commercialism and competition

management consultancy called Arthur D. Little in 1886); John B. Pine (Wall Street lawyer); Mark S. Reardon III (attorny); Lloyd N. Scott (Wall Street lawyer); Charles A. Stone (engineer and founder of an electrical engineering consultancy firm called Stone and Webster); James J. Storrow (Boston investment banker and played a formative role in setting up General Motors); Elihu Thomson (electrical engineer, holder of over 700 patents and founder with Thomas Edison of General Electric. 'Interactive Timeline,' Research Corporation for Science Advancement. Retrieved from the Worldwide Web on January $5^{\text {th }}, 2013$ :

http://www.rescorp.org/about-rcsa/history/timeline.

${ }^{46}$ Cottrell, Frederick G. (1937). The Social Responsibility of the Engineer (Reprinted from Science (85)22142215: pp. 529-533 and 553-556). The Science Press. p 5.

${ }^{47}$ Cottrell, Frederick, G. (1912). 'The Research Corporation: An experiment in the public administration of patent rights,' Journal of Industrial and Engineering Chemistry (4)12: pp. 864-867. 
between institutions and an accompanying tendency for secrecy in scientific work" ${ }^{\prime 48}$ by acting as a facilitator of disinterested and cooperative science. It did this by providing an alternative funding source for scientific research that was not driven by the interest of profit gain. In doing so, it was meant to stimulate scientific research without causing any "interference with free exchange of scientific ideas". ${ }^{49}$ Cottrell's calls several years later for the need to experiment on language to create an international language was driven by the same ideological program of harnessing the tendency of self-interest and secrecy in science. Only now the culprit was not capitalism, but nationalism.

Cottrell's use of the language of experiment, and the related ideological agenda to protect science's disinterestedness, were products of an ambitious reform ideology called Progressivism, which swept across America from the $1890 \mathrm{~s}$ until the $1920 \mathrm{~s} .{ }^{50}$ Its two highest-ranking proponents were U.S. presidents Theodore Roosevelt (1858-1919) and Woodrow Wilson (1856-1924). There was no unified Progressive movement, but the commonality between its proponents was that they promoted legislative and administrative experimentation as the answer to changes brought about by the modernization of the American society. ${ }^{51}$ These changes included the emergence of large and powerful corporations, which they presented as the cause of increasing corruption in American politics, or, just as in Cottrell's case, as a cause of a corruption of science.

A typically Progressive initiative was a political policy that developed in Wisconsin called the Wisconsin Idea, which stimulated public universities to do research directed at solving problems in the state. Proponents of the policy promoted it as a trailblazer of the Progressive movement and they often appraisingly referred to Wisconsin as a "laboratory of reform". ${ }^{52}$ Progressive reform programs like the Wisconsin Idea placed a strong emphasis on scientific and technical competence that was frequently mobilized in the form of independent expert advice commissions. The aim of these Progressive laboratories of reform was to rid society of its of individualistic excesses by facilitating openness, cooperation and impartiality in American businesses, politics, and science. Influenced by this movement, the RC and CIAL were Cottrell's attempt to establish his own laboratories of reform to restore collaboration and openness in science.

\footnotetext{
${ }^{48}$ Washburn, Jennifer (2006). University Inc.: The Corporate Corruption of Higher Education. New York: Basic Books. p. 51.

${ }^{49}$ Cottrell (nr. 46), 'The Social Responsibility of the Engineer,' p. 5.

${ }^{50}$ Cornell (nr. 27), Establishing Research Corporation, p. 168.

${ }^{51}$ Mitchell, Jerry (1999). The American Experiment With Government Corporations. Armonk, NY: M.E. Sharpe. p. 26.

${ }^{52}$ Rogers, Donald, W. (2009). Making Capitalism Safe: Work Safety and Health Regulation in America, 18801940. Urbana, IL: University of Illinois Press. p.1.
} 


\subsection{The rise of the socially responsible engineer}

The use of the language of experiment and of scientific experts was a strategy by Progressives to distinguish themselves from the conservatives and the socialists. ${ }^{53}$ They wanted social change. But they were not as radical as the socialists because they wanted to control capitalism, not destroy it. By associating themselves with scientific expertise they signaled the moderate character of in their reform politics. Their association with science was also a strategy of signaling the efficiency and impartiality of the Progressive reform program. In other words, science's and scientists image of moderation, efficiency and impartiality was a means to boost the public credibility of the Progressive program. In turn, scientists eagerly promoted this image to boost their status in society. Cottrell also pursued this program. From a strategic point of view Cottrell's RC and the CIAL were products of his political quest to boost the status of the engineer in society.

Cottrell's RC and his pursuit of international language resembled another earlytwentieth-century ideological movement in the U.S., which was the emergence of philanthropic initiatives. Cornell points out that in the first years of its establishment people were inclined to see it as a typical example of one of the new philanthropic foundations that were initiated by Carnegie and Rockefeller. To show this he cites an excerpt from a New York Sun editorial: "On February 16, 1917, the assets of the [Research] [C]orporation in cash and securities were over $\$ 217,000$. The corporation has therefore a hope, not an unreasonable one it would seem, of becoming the fairy godmother in industrial art in this country, and of doing for the factory what the Carnegie, Rockefeller and Sage Foundations are doing [in other fields]. ${ }^{54}$

Perhaps the two most prominent philanthropists were steel magnate Andrew Carnegie (1835-1919) and oil baron John D. Rockefeller (1839-1937). Their philanthropy culminated in the establishment of the two greatest multipurpose industrial philanthropist organizations: the Carnegie Corporation in 1912 and the Rockefeller Foundation in 1913. The two industrial magnates presented their philanthropy as a selfless mission of repairing aspects that technical rationality and class divisions of industrial capitalism were destroying. Carnegie claimed that the winners in society shared a responsibility to care for the weak. Rockefeller openly stated that he was a strong supporter of Carnegie's philanthropy, arguing that capitalism was a divine moral order and that his money was a gift from God and therefore it was his duty to produce more for the benefit of his fellow man. ${ }^{55}$

But Carnegie and Rockefeller had earned their wealth as hardnosed capitalists. In fact, Rockefeller's business methods for establishing and running the Standard Oil Company

\footnotetext{
${ }^{53}$ Cornell (nr. 27), Establishing Research Corporation, p. 168.

${ }^{54}$ Cited in, Cornell (nr. 27), Establishing Research Corporation, p. 167.

${ }^{55}$ Brisson, Jeffrey (2005). Rockefeller, Carnegie, and Canada: American Philantropy and the Arts and Letters in Canada. Montreal: McGill-Queens University Press. p. 24.
} 
made him one of the most reviled robber barons in the eyes of the public before he followed Carnegie in donating his wealth to social causes. ${ }^{56}$ Charles L. Ponce de Leon points out that their philanthropy was an effective strategy of fashioning a positive image of themselves by washing away the image of robber barons while at the same time the public was constantly reminded of their enormous wealth and power by the exorbitance of their donations.

Their strategy was highly effective. Ponce de Leon also points out that the two industrial tycoons were not only praised for being efficient donators to initiatives that attacked problems at their roots. American journalists also pictured them as the noble and selfless reformers that were dedicated to creating a better world. ${ }^{57}$ In a sense, Cottrell's RC appeared as a more purely philanthropic foundation that the organizations of Carnegie and Rockefeller. Their donations consisted of superfluous wealth. Cottrell did not intend the management of his patents for personal wealth. Before he could capitalize on his patents he donated them to scientific and technological research through his RC.

But while it seemed that Cottrell's scientific philanthropy was selfless in comparison to the philanthropic endeavors of the Carnegies and the Rockefellers, his engagement for the RC and, more importantly, his involvement with international language, were attempts to establish the engineer as the architect of society. Cottrell's engagement in society was a typical example of a new generation of U.S. engineers that developed an ideology William Akin calls myth of the engineer. ${ }^{58}$ Its central tenet was the claim for a more central role for technical experts in modern America.

Engineers were a newly emerging professional class in the U.S. round the turn of the century. The high demands of industry had led to a tenfold increase in number of professionally trained engineers. Fueled by the rapid professionalization of their field as well as by the continued demand for their trade, young engineers became aware of the importance of their specialized skills. National professional organizations of engineers were established and old ones were revitalized. ${ }^{59}$

This new self-awareness led some engineers to challenge the traditional nineteenthcentury self-image of engineers as servants of businessmen. They urged their colleagues to assume more responsibility by putting their skills to use of the betterment of society as a whole. ${ }^{60}$ Akin points out that a common element in the claims of these engineers was that they equated progress in society with technological advances. Such claims often went hand in hand with the suggestion that engineers had the future in their hands. To illustrate this

\footnotetext{
${ }^{56}$ Murrin, John M. \& McPherson, James M. \& Johnson, Paul E. \& Gerstle, Gary \& Rosenberg, Emily S. \& Rosenberg, Norman L. (2009). Libery, Equality, Power. Volume II: Since 1863. Belmont, CA: Clark Baxter. p. 512.

${ }^{57}$ Ponce de Leon, Charles L. (2002). Self-Exposure: Human-Interest and the Emergence of Celebrity in America, 1890-1940. Chapel Hill, NC: University of North Carolina Press. p. 160.

${ }^{58}$ Akin, William E. (1977). Technocracy and the American Dream: The Technocrat Movement, 1900-1941. Berkeley and Los Angeles: University of California Press. p. 1.

59 Ibid. p. 6.

${ }^{60}$ Ibid. p. 7
} 
tendency Akin cites the engineer Henry Gaslee Prout, who in 1906 claimed before the Cornell Association in Civil Engineers that "The Engineers more than al other men, will guide humanity forward until we have come to some other period. (...) On the engineers and on those who are making engineers rests a responsibility such as men as never before been called upon to face." ${ }^{\prime 1}$

No one sounded the rallying cry for the engineer as eloquently as the AmericanDanish sociologist Thorstein Veblen (1857-1929). In his 1919 book The Engineer and the Price System (1921) Veblen called for engineers to recognize their class solidarity and he urged them to take control of industry as the keepers of humanity's welfare. ${ }^{62}$ This analysis was inspired by the propaganda offensive of the new generation of engineers that was spearheaded by the mechanical engineer Henry Gantt (1861-1919). Influenced by Veblen, Gantt set up the New Machine, an association of engineers to promote the idea that political processes should be viewed in terms of technological processes. Their aim was, of course, to make clear that engineers should become the new industrial leaders.

But by presenting the engineer as a revolutionary and an upsetter of the status quo in society, Veblen failed to see the status seeking nature of the engineering movement. Because in Cottrell's eyes The Engineer and the Price System offered a ready-made argument for claiming that the engineer was to be tomorrow's architect of society. In a 1937 address titled 'The Social Responsibility of the Engineer', Cottrell enthusiastically proclaimed that Veblen "has perhaps most clearly sounded the challenge" for a better society. He continued by stating that: "scientists and engineers as a class have a peculiar responsibility to society for leadership in certain directions which they have on the whole not fully appreciated". ${ }^{63}$

Following Veblen, Cottrell claimed that the engineer had become a cog in an economic machine ruled by an over-dominant financial- and promotional minded managers and that class had for too long neglected the interest of the workers and the community. He argued that the corporate manager served the system of scrupulous profit gain as opposed to serving the public. By fostering the negative force of self-interest the corporate manager obstructed the path to a better society. Cottrell presented scientists and the engineers as different creatures entirely, claiming that by virtue of their "temperament" and "training", they displayed a tendency "to think most naturally in terms of service and utility". 64

To break the rule of the corporate manager Cottrell claimed it was high time for the young engineer to step up and take charge: "What I want to bring out is the crying necessity and splendid opportunity for the young engineer of creative imagination and moral courage to join forces with his brother specialists from the humanitarian side and

\footnotetext{
${ }^{61}$ Cited in, Akin (nr. 58). Technocracy and the American Dream: The Technocrat Movement, 1900-1941, p. 8.

${ }^{62}$ Augspurger, Michael (2004). An Economy of Abundant Beauty: "Fortune" Magazine and Depression

America. Cornell: Cornell University. p. 71.

${ }^{63}$ Cottrell (nr. 46), 'The Social Responsibility of the Engineer,' p. 1.

${ }^{64}$ Ibid. p. 1.
} 
thus insure a really comprehensive picture of what homo sapiens (...) should be driving at as the immediate and conscious goal for the species." 65

\title{
4.6 Cottrell's I.L.: an instrument of American expansionism
}

In addition to propelling the myth of the engineer, Cottrell's linguistic internationalism was also a product of sudden postwar U.S. dominance in Europe. We saw that Ostwald's quest to re-establish the German scientist as a purveyor of culture was synonymous with a program of maintaining and expanding what he claimed was his nation's leading role in the international community as a purveyor of organizational culture. Similarly, Cottrell's selfimage as architect of his own national community went hand-in-hand with the notion of being an architect of the international community in the service of his home nation. During World War I Cottrell was one of the principal directors of research that resulted in a cheaper production of helium for observation balloons. Like many of his colleagues, the experience of World War I enhanced his sense of societal relevance. As soon as the war ended he followed the broader trend in U.S. politics by shifting his focus to the recovery of Europe:

\begin{abstract}
Thee experiences of the war have served to illustrate as never before the importance of the position held by the scientist both pure and applied, not only to our daily lives at home, but also in international affairs. (...) The war certainly furnished a great stimulus to discovery and invention, but from the standpoint of technical achievement it bids fair to have served only as the prelude to a faster industrial development of truly international character which may reasonably be followed in its wake. The stress and strain of the period we have passed through has awakened the imagination of the rising generation to a world consciousness as nothing less far-reaching could possibly have done (...). ${ }^{66}$
\end{abstract}

Cottrell added: "we in this country are destined perhaps even more than those in Europe itself to feel the full effect of this swelling impulse (...)". This impulse boiled down to a broader urge among his fellow countrymen to expand the economical and industrial power of the U.S. by fostering closer economic and industrial cooperation with countries in Europe.

\footnotetext{
65 Ibid.

${ }^{66}$ Cottrell (nr. 20), 'Willard Gibbs Medal Award: Medal Address International Scientific Relations By F.G. Cottrell,' p. 697.
} 
Cottrell's calls for the engagement of his scientific peers for the reconstruction of Europe was an echo of Wilson's postwar foreign policy, which was to maximize America's influence in Europe to minimize the influence of Europe on America. This policy was driven by the dictum that in the newly interconnected world America had to influence or be influenced. ${ }^{67}$ Wilson's plan was to ensure the safety of America by taking control over the reconstruction process in Europe. For in his eyes a long lasting and stable peace in Europe reduced the threat of war on his country. Wilson claimed that League would make an end to the European tendencies of militarism and national chauvinism that had caused the war by adhering to the just principles of fair play and democracy.

Wilson's league was founded in 1919 as a result of the Treaty of Versailles, which officially ended the war between Germany and the Allied powers. But the treaty that provided the creation of the League only deepened the rift between the Allied forces and the Central Powers. Wilson's League sided with the Allied forces against the Germans, claiming that the choice was between the League's 'fair play' or a return of Germanism, which he described as selfish, arrogant and an inclination to take upon arms at the whim of a hat. ${ }^{68}$ Pressured by the French and Belgians, who were particularly angry due to the invasion of their land, the Germans were forced to sign a treaty that placed the blame for starting the war squarely on them. ${ }^{69}$ Germany was not only forced to give up its colonies as well as most of its European territories. It was also excluded from participating in the League.

As pointed out in the previous chapter, postwar antagonisms between the Allied nations and the central powers were mirrored in the international scientific community. French and Belgian scientists were especially resistant to resuming cooperation with their German counterparts. George Ellery Hale (1886-1938), an American astrophysicist and Foreign Secretary of the National Academy of Science, initiated the establishment of a new international organization in the form of the IRC to replace IAA (which had dissolved during the war). Hale had previously established the NRC during the war to coordinate research and initiate activities that served scientific, technical, industrial and strategic interests of America. ${ }^{70} \mathrm{He}$ also sought to preserve American interests on an international level. To do this Hale initially tried to preserve the IAA to restore international cooperation, but he redirected his efforts to create the IRC when America entered the war, modeling its

\footnotetext{
${ }^{67}$ Rice Pierce, Ann (2007). Woodrow Wilson \& Harry Truman: Mission and Power in American Foreign Policy. New Brunswick, NJ: Transaction Publishers. p. 112.

68 Ibid.

${ }^{69}$ Article 227 charged the German emperor, Wilhelm II, with "supreme offense against international morality and the sanctity of treaties", and article 231 laid responsibility on Germany and her allies "for causing all the loss and damage to which the Allied and Associated Governments and their nationals have been subjected as a consequence of the war imposed upon them". (1919). Treaty of Versailles. Signed at Versailles, June $28^{\text {th }}$ 1919. Retrieved from the Wordwide Web on October $17^{\text {th }}, 2012$ : http://avalon.law.yale.edu/subject_menus/versailles_menu.asp

70 Kevles, Daniel (1971). 'Into hostile camps': the reorganisation of science in world war I,' Isis (62)1: pp. 4760.
} 
political aims on the National Research Council.

When news of the plans to organize a new international scientific organization reached America, the American Chemical Society and the National Research Council ensured their influence in its formation by appointing Cottrell as one of their delegates at a preparatory inter-allied scientific meeting in London in October 1918. He was a likely candidate for this task, because by then he had spent substantial time in Europe in the interest of the U.S. Earlier in 1918, Cottrell had been in Europe as a member of a three-man Bureau of Mines commission to gather technical information on the condition of European mining after the war. In this capacity he investigated mines of the Saar, Luxembourg, and destroyed areas of Belgium and France. ${ }^{71}$ Cottrell was also instructed by the Ordnance Department of the American Expeditionary Force to inspect the Skoda steel plant in Pilsen, Bohemia (Czechoslovakia). After completing his mission there, he went to Italy to investigate if helium was present in boric acid springs of the volcanically active region of Larderello.

In the eyes of his American colleagues, Cottrell's experience in Europe made him a valuable representative at the IRC meetings. Hale personally invited him to attend the inaugural meeting of the IRC in Brussels in July 1919. In the fall of 1919, the IRC appointed a committee "to investigate and report to it the present status of and possible outlook of the general problem of an international auxiliary language" with Cottrell as its chairman. ${ }^{72}$

By strategically avoiding any reference to the existing tensions between citizens and scientists of European nations, the CIAL painted a rosy picture of the state of international affairs. Its 1923 report of progress boasted that the fruits of science and technology heralded a new age of international communication and as a result of this development, humanity was "entering an era of real world contact and consciousness, not because man in his essential nature has reached a new stage of development, but simply the result of indefatigable research, experimentation and standardization we have at length been provided with the necessary material tools". ${ }^{73}$ The adoption of a material tool in the form of an international language was to be the next step in the material and cultural interknitting of the world.

But the interknitting of the world did not involve the Central Powers. For like Wilson's League, Hale's IRC strategically kept in line with the sense of injustice felt by the Allied scientists. It ensured their dominance in the international scientific community by explicitly barring participation of scientists from Germany and Austria. In addition, by including neutral countries (the Netherlands, Spain, Switzerland, and the Scandinavian countries) the IRC prevented scientists from the Central Powers to set up their own international organization, scientists from the Central Powers became completely isolated

\footnotetext{
${ }^{71}$ Cameron (nr. 1), Cottrell: Samaritan of Science, p. 196.

72 (1920). Fifth Annual Report of the National Research Council. Washington: Government Printing Office. p. 16.

${ }^{73}$ Cottrell (nr. 2), Report of Progress, August 1923. Committee on International Auxiliary Language of the International Research Council, p. 1.
} 
since it was now impossible for them to establish an alternative international organization. $^{74}$

Importantly, Cottrell's CIAL more or less followed the political aims of its host institution, and thereby it inevitably practiced the politics of exclusion involved in these aims. A CIAL report stated that the former Allied countries were "(...) the leading nations of the world". In the same passage it continued that the Allied nations were "considering a plan for reducing the dangers of war, for the arbitration of disputes, for the widespread diffusion of culture in the arts and sciences and for the sociological and economic development of the world through the internationalization of commerce, of the fine arts, of the sciences and professions". ${ }^{75}$ But the point is that this 'widespread' diffusion of culture, which was to be facilitated by the international language, was, in fact, not so widespread. For it concerned an exchange of science between the former Allied nations from which the Central Powers were explicitly banned to participate.

So under the auspices of the IRC, CIAL's linguistic internationalism was ultimately a product of an American interest in asserting control in Europe for its own benefit. In fact, as pointed out by Thomas Bender and Michael Geyer, America was no different than Germany in its imperial politics, in that both were highly expansive on a global scale for their own benfit: "With their significant transnational interconnections, both nations might have become paragons of internationalism. Yet at crucial moments in their history, they turned global interconnections in the direction of embracing empire". ${ }^{76}$

Cottrell's pursuit of international language occurred at such a crucial moment when America asserted its international dominance in Europe under the guise of creating a safer world. Like Wilson and Hale, Cottrell was an advocate of an American reorganization of Europe. Like them he was aware of the skepticism with which his European colleagues viewed their sudden engagement to secure a safer Europe:

If we were to work most effectively with our foreign colleagues we must acquire a sympathetic understanding of their points of view, whether we entirely agree with them or not, and where we do not agree let us hope we will restrain ourselves sufficiently to avoid unduly adding to the party justifiable and now rather widespread impression among Europeans that so many Americans feel themselves thoroughly competent both from experience and native ability to come over and quite de novo reorganize European civilization on a (to them) thoroughly satisfactory basis. ${ }^{77}$

\footnotetext{
${ }^{74}$ Schroeder-Gudehus, Brigitte (1975). 'Challenge to transnational loyalties: international scientific organizations after the First World War,' Science Studies (3): pp. 93-118.

75 Ibid. p. 14.

${ }^{76}$ Bender, Thomas \& Geyer, Michael (2010). 'Empires: Might and Myopia,' in Mauch, Christof \& Patel, Kiran Klaus (eds.), The United States and Germany During the Twentieth Century: Competition and Convergence, pp. 13-31. Cambridge: Cambridge University Press. p. 13.

${ }^{77}$ Cottrell (nr. 20). 'Willard Gibbs Medal Award: Medal Address International Scientific Relations By F.G.
} 
Cottrell might well have hoped that he and his fellow American chemists were able to restrain themselves from reorganizing Europe in their own interest. But his efforts under the IRC to work towards the 'international' adoption of a single artificial language were, in fact, an attempt to do exactly that.

\subsection{The social responsible engineer and American philanthropy join forces}

Cottrell left the Bureau of Mines in 1921 to chair the Chemistry and Chemical Technology Division of the NRC in Washington. In that capacity he continued to organize support for the scientific international language cause as the CIAL's chairman of the IRC. A 1920 NRC report indicates that Cottrell "secured funds from gifts from various private sources" and "cooperation through the appointment of a special committee of the British Association for the Advancement of Science and similar committees from the American Council on Education, besides securing active support from several American universities". ${ }^{78}$ It is unclear if Cottrell's efforts led to any concrete steps towards a constructive study of the international language subject. What's clear is that Cottrell did not manage to get enough funding to keep his committee alive. In 1923 the CIAL was officially disbanded, marking the end of Cottrell's engagement for the international language in the scientific community. But the disassociation of the CIAL did not mark the end of Cottrell's involvement with international language.

In 1924 Cottrell helped to establish the IALA together with the well-connected and wealthy American couple Alice Vanderbilt Morris and Dave Hennen Morris. The association was born out of a convergence of Cottrell's political agenda (which we saw involved establishing the engineer as the architect of a new society and furthering America's influence in Europe), and Morris Vanderbilt's philanthropic agenda. Morris Vanderbilt was the granddaughter of William Henry Vanderbilt (1821-1885), a wealthy American businessman and philanthropist. The Vanderbilts counted as one of the most prominent industrial families in America together with the Carnegies and the Rockefellers.

The infamous shipping and railroad magnate Cornelius Vanderbilt (1794-1877) made the family fortune. In the eyes of his critics he was the personification of a robber baron. The railroad titan was also frequently quoted with statements that presented a man that trampled on the public interest. Some even claimed that the term "robber baron" was used for the first time in a newspaper article that compared Vanderbilt to German barons who raided ships on the Rhine. ${ }^{79}$ His son, William Henry Vanderbilt, also had a public reputation of being ruthless. In 1883 , in reaction to outcries by a public that was tired of

\footnotetext{
Cottrell,' p. 698.

78 (1920). Fifth Annual Report of the National Research Council. Washington: Government Printing Office. p. 17.

${ }^{79}$ Markham, Jerry W. (2002). A Financial History of the United States. Volume I: From Christopher Columbus to the Robber Barons (1492-1900). Armonk, NY: M.E. Sharpe, Inc. p. 253.
} 
expensive and dangerous railroad service, he was reported to have stated, "The public be damned!; I'm working for my stockholders". ${ }^{80}$

William Henry Vanderbilt had inherited $\$ 100$ million from his father. He managed to increase his inheritance to $\$ 194$ million, making him the richest man in America when he died nine years later. To improve the public's image of the Vanderbilts, he followed Carnegie and Rockefeller in establishing his family name in philanthropy by giving substantial gifts to Vanderbilt University, Columbia's College of Physicians and Surgeons, and numerous other recipients. He also left a substantial part of inheritance to the Metropolitan Museum of Art, the Young Women's Christian Association (YMCA), and several churches and hospitals. Raised in a family tradition that dictated that the women became engaged in philanthropy, Alice Morris Vanderbilt followed in the footsteps of her mother, Margaret Louisa Vanderbilt (1845-1924), and her aunt, Alice Gwynne Vanderbilt (1845-1934), by working for the YMCA. Her mother was an active supporter of the YMCA and her aunt donated to many chartable causes, including YMCA, Salvation Army, Red Cross, and several churches.

Dave Morris, Alice's husband, also came from a wealthy American family. Before graduating in 1896 from Harvard University as a lawyer, he inherited substantial wealth when his father died in 1895. His father, John Albert Morris (1836-1895), had also benefitted from a large inheritance. He was an American businessman who was widely known as the "Lottery King", a prominent persona in the thoroughbred horseracing scene. He managed to increase his wealth substantially by investing in the Louisiana State Lottery Company. Like his father, Dave Morris was a thoroughbred racehorse owner. The money he earned with horse breeding and his inheritance allowed him to own business interests in hotels, railroads, and other businesses. ${ }^{81}$

Early onwards in their marriage the Morrises exhibited the philanthropic tendencies that were part and parcel of the American upper class by the end of the nineteenth century. Before they became interested in the international language they shared the dream to found a hospital that served all people, including the poor. Alice Morris Vanderbilt became interested in Esperanto before World War I, but it wasn't until 1921 that her interest turned into a life mission. In that year Cottrell convinced her of the importance of approaching the international language from a scientific angle. Julia Falk points out that before she became involved with international language, there was "nothing to bring her to the attention of the public beyond the birth announcements of her six children and her work with the Young Women's Christian Association (...)" ${ }^{82}$ Cottrell's scientific approach endowed her newfound mission with an air of intellectual authority and professionalism.

\footnotetext{
${ }^{80}$ Cited in, Jensen, Derrick (2004). The Culture of Make Believe. White River Junction, VT: Chelsea Green Publishing. p. 416.

81 (1948). 'The Talk of the Town,' The New Yorker, September 25th (24): p. 24.

${ }^{82}$ Falk, Julia (1999). Women, Language and Linguistics: Three American Stories from the First Half of the Twentieth Century. London: Taylor \& Francis Group. p. 36.
} 


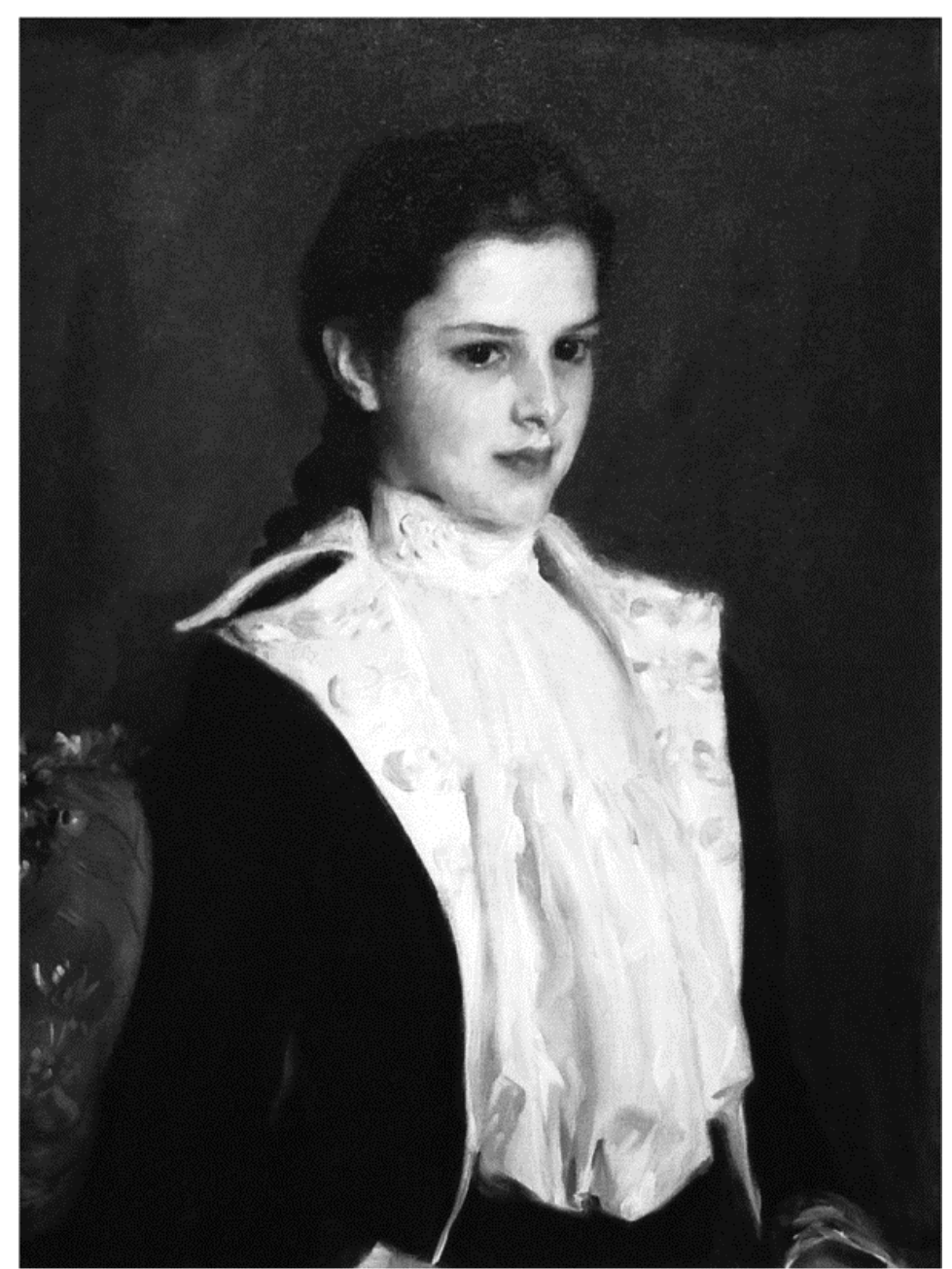

Portrait of a young Alice Vanderbilt by the American artist John Singer Sargent, a leading potrait painter of his generation. ${ }^{83}$

What made the mission of promoting an international language for peace in Europe especially appealing for the Morrises was that it was neatly aligned with the donating agenda of the American philanthropic community. Philanthropists closely trailed the U.S. postwar foreign policy of constructing a stable Europe. In 1910 Carnegie had taken the lead in this trend by establishing the Carnegie Endowment for International Peace and by building the Peace Palace in The Hague to house the Permanent Court of Arbitration and International Law. After the war, the Carnegie Endowment also built libraries in Belgium, France and Serbia. The Rockefeller Foundation did not stay behind. In 1920 it donated substantial amounts to the American Relief Administration, an impressive program to feed the Europeans. One year later the Rockefeller Foundation also provided financial aid to the

\footnotetext{
${ }^{83}$ Retrieved from the Worldwide web on February $5^{\text {th }}, 2013$ :

http://en.wikipedia.org/wiki/John_Singer_Sargent_Alice_Vanderbilt_Shepard_Amon_Carter_Museum.jpg
} 
League of Nations Health Organization. ${ }^{84}$ In 1922 John D. Rockefeller Jr. funded the formation of the Council of Foreign Relations and its first headquarters in New York. In 1927 he also donated \$2 million for the construction and endowment of the Library of the League of Nations at the occasion of his $85^{\text {th }}$ birthday.

Eager to set up her own philanthropic platform for a better world, Alice Morris Vanderbilt organized a series of organizational meetings in 1923 to gather support for her new mission. The first two meetings were held at the New York residence of her cousin, Emily Vanderbilt Sloane Hammond (1874-1970), and her husband, John Henry Hammond (1871-1949). Two hundred people attended the first meeting, which was led by Frederick Paul Keppel (1875-1943), president-elect of the Carnegie Corporation. Its participants included "faculty and student delegates from the principal universities and private schools of New York city, and college and post-graduate students of thirty different nationalities". ${ }^{85}$

Two days later a dinner and a conference were held at the New York residence of the Morrises. ${ }^{86}$ The attendees of both meetings endorsed a resolution that called for "'serious and competent consideration... [of] the subject of an international language... under the auspices of one of the well established and recognized institutions for impartial research and dissemination of knowledge'" ${ }^{87}$ It is unclear how much the attendees of the meetings donated to the cause, but the IALA was formed within a month of the meetings. Alice Morris Vanderbilt assumed the position as the IALA's honorary secretary and she invested "a sizable contribution of her own" in the association. She also contacted Rockefeller, who promised her that he would "match every contribution up to $\$ 2,500$ dollars that was raised". ${ }^{88}$ Her husband became the treasurer of the association. Herbert Shenton (1884-1937), a Columbia University sociologist, became the association's executive secretary. In this capacity he played an important role in coordinating and performing its interlinguistic work.

Cottrell accepted directorship of IALA. But from the outset he was more a financer than participant of the association's work. From 1928 onwards his RC awarded the IALA a

\footnotetext{
${ }^{84}$ Weindling, Paul (1997). 'Philanthropy and World Health: The Rockefeller Foundation and the League of Nations Health Organisation,' Minerva 35: pp. 269-281. p. 271.

${ }^{85}$ Cottrell (nr. 2), Report of Progress, August 1923. Committee on International Auxiliary Language of the International Research Council, p. 7.

${ }^{86}$ Prominent attendees included Alexander (American Association for International Conciliation), Mr. and Mrs. Hamilton Fish Armstrong (Council on Foreign Relations), General and Mrs. John J. Carty (American Telephone and Telegraph Co.), Mr. and Mrs. Edwin R. Embree (Rockefeller Foundation), and Mrs. Andrew Carnegie, Dr. Henry Haskell (Carnegie Endowment for International Peace), Dr. and Mrs. Frederick Keppel (Carnegie Foundation), Mr. and Mrs. John Glenn (Russell Sage Foundation), and Mrs. Mary K. Simkhovitch (New York Council for International Cooperation). The guests also included three professors of Columbia University: prof. Michael I. Pupin, prof. Charleton Hayes, and renowned educational reformer and philosopher prof. John Dewey.

${ }^{87}$ Quoted in, Falk (nr. 83), Women, Language and Linguistics: Three American Stories from the First Half of the Twentieth Century, p. 42.

${ }^{88}$ Cameron (nr. 1), Cottrell: Samaritan of Science, p 241.
} 
yearly grant of $\$ 4000$ dollars, which was increased to $\$ 5.500$ from 1937 until $1941 .{ }^{89}$ The $\mathrm{RC}$ also continued to play a role in the promotion of its activities through its president, Howard Poillon. Dave Hennen Morris, who had been a member of RC's board of directors since 1922, convinced Poillon of the importance of the IALA's activities. In 1935 he acted as a liaison officer between the IALA and the director of the Humanities Division of the Rockefeller Foundation (David H. Stevens) to convince the foundation to financially support "the project for Obtaining Agreement upon a definitive International Language". ${ }^{90}$ Poillon's attempts to gain financial support from the foundation were to no avail. Several months later he was informed that Stevens wasn't "convinced of the value of the aim of IALA". ${ }^{91}$

The IALA's business was a fulltime commitment for Morris Vanderbilt. She was the organizational and financial driving force behind the association. But Cottrell's involvement with international language had always been one of numerous projects and jobs to which he was committed. By the 1930s he became more and more taken up by other projects. In 1930 he left his post as director of the fixed Nitrogen Research Laboratory at the U.S. department of Agriculture in 1930, but he continued to serve as a consultant for the department. In 1935 he established an association called Research Associates Inc. It was intended as another RC that shortened the time-lapse between scientific discovery and its effect on everyday life. The RC funded the association, but the idea was that in time it became self-supporting through the return for its consulting services. Its projects included detergents, heat wave roasting, deodorizers and Royster stoves. It soon became clear, however, that the association could not support itself, leading to its disassociation in 1938.

Cottrell devoted the last decade of his life to research on nitrogen fixation. He died on November 16 in 1948 at the University of California in Berkeley.

\subsection{Interlingua: an international language by linguists for science}

The efforts of IALA's linguists culminated in the development of a new international language called Interlingua. The British linguist Edward Collinson (1889-1969) laid the groundwork for Interlingua by developing the methods of comparing and compiling international words that were used to create it. He was also IALA's Research Director from 1936 to 1939. During this period the association temporarily had its office in Liverpool, where Collinson held a Chair of German at the University of Liverpool.

But if the IALA ever was a European affair, it was only for a short period. In 1939

\footnotetext{
${ }^{89}$ (1933). International Auxiliary Association in the United States, Inc. A Report to the Research Corporation. Archive of the Research Corporation. Box 42, F. 527.

${ }^{90}$ Howard Poillon to David H. Stevens. December $2^{\text {nd }}, 1935$. Archive of the Research Corporation. Box 7, F. 82.

91 Memorandum to Howard Poillon and Herbert Shenton from H.S. Eaton in recalls with Mr. Stevens of R.F.. March $11^{\text {th }}, 1936$. Archives of the Research Corporation. Box 7, F. 82.
} 
Collinson moved to New York to continue his work on compiling international words there. But in that same year American philologist and poet Ezra Clark Stillman (1907-1995) replaced him as IALA's research director. Collinson's project was further expanded under his directorship. One of the linguists Stillman hired for this task was Alexander Gode (19061970), an American linguist and translator. From that moment onwards they would continue to play a central role in the creation and promotion of Interlingua.

Gode and Stilmann claimed that in creating Interlingua they retained Cottrell's original emphasis on the need to apply a scientific and experimental approach to the international language. In fact, IALA's mission to study language scientifically was what led them to become involved with it in the first place. As representatives of a school of American linguists that sought to promote linguistics as a serious scientific field, their association with AlLA provided them with financial support for their mission and it provided them with a social platform that enabled them to reach a broader audience.

The American anthropologist-linguist Edward Sapir (1884-1939) was a more famous representative of the same school of linguistics who also became invested in IALA's activities for the same reasons. His 1929 paper "The Status of Linguistics as a Science" is illustrative of its agenda to promote linguistics as scientific field. It claimed that IndoEuropean linguists had developed a technique that was not only virtually as perfect than that of any other social science; it even compared it to the precision and orderliness of the natural sciences: "Many of the formulations of comparative Indo-European linguistics have a neatness and a regularity which recall the formulae, or the so called laws, of natural science". ${ }^{92}$

Stillman and Gode appeared to follow closely in Cottrell's ideological footsteps by claiming that Interlingua was the product of a scientific extraction and standardization of the international vocabulary of existing languages. ${ }^{93}$ But a closer look at their arguments reveals that there was also a difference in how they conceptualized Interlingua. We saw that Cottrell claimed that what made the international language neutral and precise was that was carefully assembled in the same way in other product of science and technology was constructed. In other words, its artificial character was supposed to give it its cutting edge, because this was what made it neutral and precise. Stillman and Gode, however, presented the artificiality of constructed languages as a disadvantage. They claimed that Esperanto and Ido were too schematic and artificial because it contained borrowed and invented language elements. So in creating Interlingua, their aim was to come up with an international language that was experienced as natural for its users. They claimed to have done this by complementing Interlingua with a minimum grammar that contained no features that were missing from any of the contributing languages. The idea was that what remained were grammatical features that were shared by all the European languages.

Stillman's and Gode's emphasis on the natural character of Interlingua was

\footnotetext{
92 Sapir, Edward (1929). 'The Status of Linguistics as a Science,' Language (5)4: pp. 207-214. p. 207.

${ }^{93}$ Esterhill, Frank J. (2000). Interlingua Institute: A History. New York: Interlingua Institute. p. 12.
} 
influenced by a theory on language that was articulated by Sapir and his student Benjamin Lee Whorf (1897-1941). They proposed the idea that different language groups facilitated different ways of expressing time and space by drawing on comparative studies between non-European languages and European languages that focused on grammatical features such as tenses and verbs. ${ }^{94}$ They argued that the particular vocabularies and grammatical features of language groups produced these variations in worldview. This meant that what was experienced as natural for people, was different in different cultures. Whorf referred to the European language group as Standard Average European (SAE), which centered on English, French, German as well as on other related European languages. He argued that what distinguished SAE from other language groups was that it shared a grammatical structure that expressed a notion of time as something physical that can be broken down into the units past, present, and future with a progressive line that runs through it. ${ }^{95}$

In 1951 IALA finally published an Interlingua-English dictionary titled InterlinguaEnglish: A Dictionary of the International Language. It was accompanied by the grammar of Interlingua in a separate publication. Following Whorf's theory on language, Gode referred to Interlingua as SAE, claiming that it retained the basic linguistic features that characterized the European language group. In doing so, he presented a scientifically forged language that was truly international, not because of its logical, regular and rational grammatical features, but because it only contained grammatical features that were natural to the SAE language group.

Romance and West Germanic languages formed the core of Whorf's SAE. Gode's Interlingua was more heavily based on Romance languages. In addition to English, Gode had chosen French, Italian, Spanish and Portuguese as the core languages of Interlingua. In doing so he basically retained Whorf's as well as Couturat's narrow definition of 'average' European. By centering SAE on Romance and West Germanic language, Whorf had made North-Germanic and Balto-Slavic languages peripheral members of the European language group. Similarly, we saw that Coutuart had eliminated the Slavic elements from Esperanto in order to create Ido.

Gode's 1951 dictionary was the first and the last Interlingua publication that was issued under the auspices of the IALA. Alice Morris Vanderbilt kept the association afloat with her family's inheritance. When she died in 1950 her financial support of the AILA came to an end, forcing the association to close its doors three years later. But in 1956 Gode found a new platform for the promotion of Interlingua in a non-profit organization called Science Service (currently known as Society for Science and Public). Science Service was established in America 1921 by journalist Edward W. Scripps (1854-1926) and Zoologist William Emerson Ritter (1856-1944) in collaboration with the AAAS, NRC and the National Academy of Sciences to increase and improve the public dissemination of scientific and technological information science. The years after World War II marked the heyday of

\footnotetext{
${ }^{94}$ Thomas, Linda \& Wareing, Sha N. (2005). Language Society and Power: An Introduction. New York: Routledge. p. 23.

${ }^{95}$ Baghramian, Maria (2004). Relativism. Oxfordshire: Routledge. p. 93.
} 
Science Service. Science's spectacular wartime achievements, including the Manhattan Project, led to public calls for "an additional supply" of popular science. ${ }^{96}$ Boosted by this favorable public climate, Science Service promoted science through education programs and publications, including Science Newsletter and Scientific Monthly.

The partnership between Gode and Science Service was forged under the directorship of engineer and science writer Watson Davis (1896-1967). Davis was the director of Science Service from 1933 until 1967. He was also a pioneer in the field of information science as well as founder of the American Documentation Institute (the forerunner of the American Society for Information and Technology). Keen to encourage the public's appreciation of science's utility in society, Watson became an Interlingua supporter. Consequently, in 1953 Science Service founded an Interlingua Division with Gode as its director. His first Interlingua publication in that capacity was an introductory manual titled Interlingua a Prime Vista. He published numerous articles on Interlingua in Scientific Monthly and he wrote a monthly column in Science Newsletter until his death in 1970.

In 1970 the Interlingua Division was succeeded by the Interlingua Institute, which promoted Interlingua in the U.S. and in Canada by producing Interlingua summaries for scholarly and medical publications. One of its biggest achievements was the publication of two volumes on phytopathology (the scientific study of plant disease) in 1976 and $1977 .{ }^{97}$ But like Ido, Interlingua never gained any serious support in the scientific community. It found more support outside of the scientific community by former adherents of other international language programs, including Esperanto. One of these supporters founded the Union Mundial pro Interlingua (UMI) in 1955, which currently still promotes Interlingua.

\footnotetext{
${ }^{96}$ Cited in, Lewenstein, Bruce (1992).'Public Understanding of Science in the United States after World War II,' Public Understanding of Science (1): 45-68. p. 49.

${ }^{97}$ Esterhill (nr. 93), Interlingua Institute: A History, p. 36.
} 



\section{CHAPTER 5}

\section{Constructing worlds with words: on the myth and function of scientific internationalism}

Looking back at the previous three chapters, the early-twentieth-century attempts to promote an international scientific language seem to tell a story of human all too human conflict and failure. Like Brigitte Schroeder-Gudehus' classic work, the three case studies debunk the myth that "the sciences were never at war". The scientists involved simply did not display the degree of cooperation assumed in the ideal of scientific internationalism. Think of Couturat's disagreement with Bertrand Russell about Ido's necessity and the subsequent end of their friendship and of Ostwald's clash with Jacobus Van 't Hoff on the issue of publishing Ido abstracts in the Die Zeitschrift für Physikalische Chemie. We also encountered a battle between the Idists and the Esperantists, which led Ostwald to end his collaboration with Couturat. Ostwald continued the promotion of Ido in Switzerland in an attempt to bypass what he referred to as the war between the two rivaling international language groups. Hunted by disagreement and failure, the early-twentieth-century attempts to promote international language were clearly a messy affair.

As indicated in the introduction the goal of the three reconstructions on the previous pages was to flesh out a historically grounded image of this particular case of early-twentieth-century scientific internationalism. In doing so we saw that in contrast to De Beer's claims, scientific cooperation did not float freely above personal and national politics. And in contrast to Schroeder-Gudehus, who interpreted the diverse political and 
ideological agendas as the failure of scientific internationalism, I have shown that in fact they formed its driving force.

In this chapter I want to further develop the notion of scientific internationalism as an expression of differing agendas. Section 1 does this by describing it as an expression of differing conceptions and interests that were a product of a range of local scientific and political contexts. Building on these differences, section 2 points at our protagonists' narrow definitions of what constituted the international arena as well as at the narrowness of their shared conception of how and what was supposed to be communicated internationally in the first place. The same section concludes with a refinement of Paul Forman's definition of scientific internationalism as a matter of national competition at an international level by pointing out that our protagonists themselves had different conceptions of what their internationalism was about.

The second half of this chapter concludes this dissertation with an analysis of internationalism as a strategy of community building. To do this I will adopt methodological perspectives from the study of nationalism. In a series of classic studies, Eric Hobsbawm, Ernest Gellner and Benedict Anderson have developed approaches to the study of nations that view these as social constructions, that is: as products of active community building. In opposition to primordialists, who hold that nations are products of age-old blood bonds and geographical boundaries, they see nations as modern entities that are constructed through the political campaigning of a shared national identity. ${ }^{1}$ I will take over this approach but apply it to a different level: not that of national but of international community. $^{2}$

What makes this methodological transfer especially promising is the commonality of one of the main means of community building: language. The social-constructivist approach to nations has shown the creation of shared, standardized languages to be one of the chief instruments of aspiring nationalists. Similarly, but at a different level, I will study language as a prime tool for international community building. This is particularly salient as the attempts of our protagonists occurred in the historical period that has become known as the apogee of language nationalism. Between 1870 and 1914 language became the principal identifier of nationality all over Europe. Moreover, language was considered as such by both governments and citizens for the first time in history. ${ }^{3}$ It was exactly against this background that our protagonists developed their linguistic internationalism.

The methodological and historical relevance of the social constructivist approach invites a more thorough examination. To perform this task, section 3 lays out in what ways nationalist agitators mobilized language to construct a shared national consciousness.

\footnotetext{
${ }^{1}$ Hobsbawm, Eric (1992). Nations and Nationalism Since 1780: Programme, Myth, Reality. Cambridge: Cambridge University Press. p. 12.

${ }^{2}$ For the tension between nationalism and internationalism, see also, Randeraad, Nico (2010). States and Statistics in the Nineteenth Century: Europe by Numbers. Manchester: Manchester University Press.

${ }^{3}$ Hobsbawm (nr. 1), Nations and Nationalism Since 1780: Programme, Myth, Reality, pp. 98-100.
} 
Drawing on the work of several contructivist historians, I will identify the arguments and strategies of several early nineteenth-century linguistic nationalists from France and Germany. In doing so, I show that nationalists attempted to establish the uniqueness of their community vis-à-vis other national communities by defining and describing language as an expression of what they claimed were the distinct qualities and virtues of their people. In the same process language was also used to trace these qualities and virtues into the distant past to construct the idea of a shared history that confirmed the uniqueness and supremacy of the nation in question.

Section 4 analyzes how our protagonists mobilized language as a community builder at an international level. Like the nationalists, they presented their language as a unique expression of the virtues and values that defined and connected the members of their community. And like the nationalists, they mobilized language to link their community to an idealized past to emphasize its extraordinary reputation and to unify its users by reminding them of their shared heritage. While our protogonists differed from nationalists by claiming that their language was artificial and highly rational because it was scientifically assembled, it is also argued that they nonetheless followed the nationalists by endowing their language with mystical qualities.

Finally, by drawing on Benedict Anderson's conception of nations as imagined communities, section 5 argues that like nationalism, scientific internationalism is maintained by a largely fictional, or imagined, narrative of comradeship between its proponents.

\subsection{The diversity of scientific internationalism}

In the previous chapters I reconstructed the involvement with international language of our three protagonists. Taken together these stories provide a chronological account of what can loosely be called the early-twentieth-century movement of linguistic scientific internationalism. This broader narrative ran from about 1900 until the 1930s. Couturat's activities, which involved setting up the DAIL in 1901 in France and the creation and promotion of Ido from 1905 onwards, formed the starting point of the movement. Ostwald's collaboration with Couturat and his subsequent promotion of Ido as part of the "Brücke's" organization program was the next step of this movement. Couturat's death and Ostwald's conversion to "Weltdeutsch" in 1915 marked an end to the promotion of Ido. But it did not end the promotion of an international language for science. During World War I Ostwald presented "Weltdeutsch" as the most appropriate language for the communication of international science. On the other side of the Atlantic Ocean, 1914 marked the beginning of Cottrell's involvement with the promotion of a scientific international language, leading him to campaign for the need of a scientific approach to the subject from 1919 onwards as the chair of the CIAL of the IRC and from 1924 onwards as 
one of the founding members of the AILA.

If we look back onto the entire history and take a bird's eye perspective, the movement of linguistic scientific internationalism appears as a product of the following late nineteenth and early twentieth century ingredients:

1. The emergence of conscious internationalism, that is movements, organizations, congresses, and journals in all fields, including politics, law, trade, and most importantly, the scientific community, that were explicitly called international. ${ }^{4}$

2. The notion that the advances of science and technology contributed to an increasing interknitting of the world by facilitating the international travel and communication.

3. The increase in number of national languages in which science was communicated.

4. The popularity of international languages, including artificial languages (such as Esperanto, Volapük), a revival of Latin, and national languages as international languages.

5. The notion of moral duty of the scientist to intervene rationalize and thereby civilize international communication within the scientific community to ensure the efficient transfer of scientific knowledge, and ultimately to rational and civilize international relations in general in an attempt to relegate war and conflict to the past.

These ingredients broadly connect the early twentieth century attempts to advance an international scientific language. But uniformity appears only at the surface of the movement. At a more fundamental level the three previous chapters have revealed the diversity in ideological agendas that lay behind the three campaigns. What has become clear is how different were the motivations, interests, and values that guided the protagonists' actions. While De Beer, Schroeder-Gudehus and more recently Mark Mazower have, each in their own way, presented scientific internationalism as a homogenous ideology, this thesis has shown that it falls apart into a variety of ideologies.

This ideological diversity, moreover, can be seen to express itself on four levels. Firstly, what our actors deemed scientific about international language was different in each case. Couturat's claims of Ido's efficiency and neutrality were an expression of his notion of mechanical logic that was a product of his work on Leibniz and his involvement in a particular field of logic called symbolic logic. Ostwald conceptualized Ido's effectiveness and neutrality in terms of its capacity to facilitate efficient international energy transfer by

\footnotetext{
${ }^{4}$ Geyer, Martin \& Paulmann, Johannes (2001). 'Introduction. The mechanics of internationalism,' in Geyer, Martin H. \& Paulmann, Johannes. (ed.), The Mechanics of Internationalism. Culture, Society, and Politics from the 1840s to the First World War, pp. 1-26. Oxford: Oxford University Press. p. 2.
} 
virtue of both its simplicity and the fact that it bypassed the use of multiple national languages. In doing so, his idea was that less energy was wasted by translations, both in journals and at conferences. This conception was a product of his work as a physical chemist that involved conceptualizing chemical reactions in terms of energy transfer. Cottrell promoted another variation of a scientific international language. His conception of language as a technological tool clearly bore the stamp of his background as an engineer. In his eyes the supposed efficiency and neutrality of a scientifically selected artificial language for international communication was to be understood as any other technological device, such as the telephone and the radio.

Secondly, the contours of the three diverging ideological programs were also visible in the intellectual role models on which they based their scientific internationalisms. Couturat's linguistic internationalism was strongly inspired by Leibniz's logic and his work on his characteristica universalis. It provided Couturat with an example for his own project, and in presenting it as an example Couturat forged an image of Leibniz as a scientific internationalist avant la lettre. Ostwald's promotion of international language involved the appropriation of the ideas the French positivist August Comte. We saw that Ostwald mobilized Comte's teleology to claim that society was moving towards an increased state of rational and efficient international organization. Cottrell appropriated Thorstein Veblen's celebration of the engineer in The Engineer and the Price System. Veblen proclaimed the supremacy of scientists and industrial technology as a means to create a better society. He was hopeful that the engineer was going to play a central role in toppling the capitalist order by taking central stage in modern society. The end product of this development was supposed to be a socialist utopia, but Cottrell mobilized Veblen's celebration of the engineer as a means to enhance the status of the engineer in the existing society.

Thirdly, in each case the involvement with international language was a product of a status enhancement campaign of their profession, either within the context of the scientific community or in the setting of the national culture. We saw that Couturat's application of logic to create Ido was a part of a late nineteenth and early twentieth century campaign by a small group of logicians, philosophers and mathematicians that Lorraine Daston and Peter Galison describe as the displacing an older form of objectivity, called mechanical objectivity, by a newer form, structural objectivity. ${ }^{5}$ This involved creating a logical structure in the form of mathematics, or, in Couturat's case, a scientific language that supposedly by-passed human mediation entirely. In doing so, they sought to establish their field's authority in establishing certain and objective knowledge. Ostwald's energetic reform program was a typical example of a contemporary tendency among German scientists to revive the nineteenth century ideal of the scientist as a culture bearer. They lamented that their work no longer pertained to the whole of society but only to specific industrial processes or disciplines. Ostwald's application of the principles of energetics to all processes in society (including international communication) and his subsequent attempt

\footnotetext{
${ }^{5}$ Daston, Lorraine \& Galison, Peter (2007). Objectivity. New York: Zone Books.
} 
to promote an organizational reform program on the basis of these principles (including the promotion of (do) was a campaign to assert his role as a culture bearer for Germany. Cottrell's engagement for international language was an expression of the rise of the American engineer as a new class. His campaigning of the socially responsible engineer his related calls for the need to apply scientific and engineering principles to social issues (including the adoption of a scientific international language to smoothen international communication), were part of his agenda of status enhancement of of the engineer in American politics.

Fourthly, linguistic internationalism of our protagonists was an expression of diverging national perspectives, in that each sought to facilitate a different world order in which their nations remained or became the center of gravitas. Couturat's creation and promotion of Ido was more than the promotion of logic to establish structural objectivity. He mobilized logic to repair and maintain the status of France as a leading nation of culture. Couturat was critical towards the chauvinistic anti-Dreyfussards, but the damage he claimed they did to the international reputation of France was his main concern. Couturat presented the affair as a "sad and shameful page in the history of the French Republic" and he claimed that the international community viewed it without sympathy. These statements reveal that Couturat believed that France was a role model for the entire international community. By creating Ido as a language for science as well as for international diplomacy he attempted to reposition France as a leading nation of culture in Europe.

Ostwald promoted Ido in the context of an internationalist program that was meant to establish a world order that was clearly at odds with Couturat's. We saw that he presented the "Brücke's" organizational reform program (which involved the implementation of Ido) for an efficient communication of intellectual work as the latest product of Germany's advanced organizational culture that would eventually outdo a Latin oriented world culture. In its place Ostwald envisioned a German Empire that stretched from Germany to China and that was to be the largest and most culturally advanced territory the world had ever witnessed.

Cottrell's promotion was no less a means of ascertaining the cultural and organizational dominance of his home nation in the international arena. Set in the context of a new post-World War I American dominance under Wilson's leadership, Cottrell's promotion of an international language as chairman of the CIAL of the IRC was supposed to contribute to securing a stronger American foothold in Europe. In doing so, the world order that was supposed to emerge involved the displacement of Ostwald's envisioned German Empire. For we saw that the American intervention in Europe aimed to supplant the nationalistic and militaristic tendencies Germany displayed during World War I. In fact, we saw that American policy was just as much geared to dominate the world stage as Germany's had been before the war. This new American policy was supported by the former Allied nations in Europe, leading to the exclusion of Germans and Austrians from participating in both the League of Nations and the IRC. 


\subsection{The narrowness of scientific internationalism}

So instead of exhibiting a smoothly aligned program of international cooperation between scientists that transcended national rivalries, the three scientific internationalisms presented conflicting claims of national dominance in the international world. In this respect their internationalist programs were no different than any other internationalist movement in that period. In the Mechanics of Internationalism (2001) Geyer and Paulmann point out that "Movements across national borders increased enormously [around 1900], but the opening up of the world was also a process of inclusion and exclusion involving issues of national authority, identity, and power". ${ }^{6}$ Likewise, our three protagonists mobilized their authority as disinterested architects of a new and better world in the advantage of the nations they represented. The home nation was-and was supposed toremain at the center of the global order they designed. As such, the circulation of knowledge they envisioned was by no means limitless and open-ended.

We saw that Couturat's internationalism was very different from Leibniz's Christian universalism. But we also saw that notions of world order were both highly Eurocentric. Couturat made no mention of international cooperation with the Far East, the Middle East, Africa or Latin America. For Couturat international meant Europe and the U.S. And when he referred to his own creation as a quintessence of European languages, he meant Western European languages only. For Ido was almost exclusively created out of romance language since Couturat had eliminated Slavic elements from Esperanto to make it more 'efficient' and 'easy' to use.

By contrast, Ostwald's conception of the international arena included Eastern Europe, the Middle East and the Far East. In his eyes Eastern Europe and the Ottoman Empire served as a bridge that connected Germany with the Far East. His interest in the inclusion of these regions was merely instrumental, because they served as stepping-stones for the expansion of Germany to the Far East. We even saw that Ostwald literally conceptualized the international community as a territory that was waiting to be colonized. Ido, which Ostwald later exchanged for "Weltdeutsch", was a linguistic tool that was supposed to contribute to the contruction of this new German empire.

Cottrell's geographic conception of the international community was more or less the same as Couturat's. His world order also revolved around Western Europe and the U.S., although the US obviously formed its centre of gravitas. We also saw that the rational and open cooperation Cottrell promoted was, in fact, far from all-inclusive. For it centered on the U.S. and her Allies and excluded the central powers. The CIAL report made no mention of fostering communication with the rest the world.

In addition to presenting narrow - but divergent - conceptions of international world orders, the three protagonists shared a narrow conception of what and how one was supposed to communicate internationally. For we saw that they emphasized rationality,

\footnotetext{
${ }^{6}$ Geyer \& Paulmann (4.), 'Introduction. The mechanics of internationalism,' p. 9.
} 
efficiency and precision as the desired qualities of international communication. With these qualities their language was supposed to infuse international communication with rationality and efficiency to minimize what they claimed were negative tendencies of emotionalism and chauvinism in communication. In their eyes these tendencies belonged to the realm of the irrational and primitive, which they equated with outdated and unproductive tendencies of national chauvinism.

Our protagonists never explicitly criticized literature and poetry, which can be seen as representing the lyrical, emotional and national, as unwelcome subjects for international communication. But the mere fact that they never mentioned the arts in the first place indicates that they viewed these as irrelevant for international communication. Moreover, we did see that they criticized the historical character of national languages. Couturat described them as highly inefficient and imprecise exactly because they were products of a "slow evolution". Ostwald suggested that national languages were nothing but ruins, remnants of the past, by comparing them with worn-out houses that urgently needed to be torn down. And Cottrell complained about the tendency of scientific contemporaries to approach language as a sacred product of long history that could never be artificially created.

The narrowness and apparent dryness of our protagonists' conception of a rational efficient exchange of information that left no room for arts and humanities was perhaps the main reason for Bertrand Russell's refusal to support the "idiots". Like our protagonists, he believed that mathematics and science were the most important vehicles for understanding the world. But Russell also believed that an educated man of the world was supposed to have an interest in and knowledge of history and literature. In fact, he believed that important ideas and insights were conveyed through literature and poetry:

I liked a number of books of very different kinds because I found in them expressions of the different kinds of feelings that tossed me hither and thither on contending waves. I cared for beauty, especially in poetry and in nature. I wanted some kind of vivid hope for the destiny of mankind. (...) Underneath all these emotional attitudes was a desire to understand the world, which I hoped to do as far as possible by means of mathematics and science. ${ }^{7}$

Even George Sarton criticized the idea of an artificial language for international communication. As mentioned in chapter I, he was also a passionate scientific internationalist and a typical positivist. His efforts of compiling and promoting science's

\footnotetext{
${ }^{7}$ Russell, Bertrand (2005[1957]). 'The Importance of Shelley,' in Russell, Bertrand \& Bone, Andrew G. (ed.), Collected Papers of Bertrand Russell. Volume 29: Détente or Destruction, 1955-57, pp. 75-78. London/New York: Routledge. p. 75.
} 
past as a positive mirror for humanity's future was a variation of the early-twentiethcentury idea of science as motor that propelled society towards a unified world. ${ }^{8}$ At one point he expressed an interest in Ido, arguing against Otlet that Ido, not Esperanto, was more likely to be "the most perfect and simplest international language". ${ }^{9}$ But in The History of Science and New Humanism (1937) Sarton presented artificial language as narrow and reductionist. ${ }^{10}$

Sarton not only claimed that the use of national languages for international communication did not lead to conflict. He also argued that national languages led to a better understanding of the other and of one's own culture. He reasoned that by learning at least one foreign language one increased the understanding of one's mother tongue, because it led one to become "gradually consciousness of many subtleties" one took for granted. ${ }^{11}$ Moreover, he claimed that each natural language opened a "new horizon" that helped "one to know more intimately another people, another culture, and thus by comparison to be more sensitive to the qualities and to the defects of one's own inheritance". ${ }^{12}$

But while Russell's and Sarton's views on language and international communication further expose the narrowness of the artificial international language project of our protagonists, they themselves did not perceive it as such. They shared a general conception of the scientist as a supreme architect of a unified world. In their eyes scientific knowledge gave them the exclusive capacity to create a language that served the international community by facilitating a neutral and precise transfer of knowledge by virtue of its disinterested and rational character. They argued that these qualities ensured that their

\footnotetext{
${ }^{8}$ Sarton presented a history of the community of knowledge makers that was remarkably broad in terms of the global inclusiveness of its participants. He believed that science's development was the cumulative product of many individuals from different cultures. It featured China and the Middle East as contributing cultures to his synthetic history of science. The global and periodical scope of his history was a product of Sarton's background in the humanities. But Sarton's ideas were not free of Eurocentrism. He claimed, for instance, that many non-European cultures were backward in terms of their political structure, describing them as "old civilisations that were based upon the existence of slaves or their equivalent; only very few men were allowed to share its blessings". Sarton, George (1988[1937]). The History of Science and the New Humanism. With Recollections and Reflections by Robert K. Merton. Brunswick, NJ: Transaction Inc. p. 17.

${ }^{9}$ Pyenson, Lewis \& Verbruggen, Christophe (2009) 'Ego and the International: The Modernist Circle of George Sarton,' Isis (100): pp. 60-70. p. 68.

${ }^{10}$ Sarton, George (1988[1937]). The History of Science and the New Humanism. With Recollections and Reflections by Robert K. Merton. Brunswick, NJ: Transaction Inc. p.125.

${ }^{11}$ Ibid, p. 126-127.

12 Sarton nonetheless proposed an alternative international language that was not constituted by words and phrases. Instead, it consisted of formulae, sounds and drawings. Because in his eyes the most essential and international human languages were mathematics, music, and drawing: "The teaching of music, drawing, and painting ought to be far more common than it is (...). To be sure its aim would be (...) simply to open more eyes and ears to all the unspeakable beauties of the visible and audible worlds, to multiply men's changes of communication with other men and women, to increase their humanity and their happiness". Sarton (nr. 9), The History of Science and the New Humanism, p. 127.
} 
language would contribute to a more tightly integrated and harmonious world order. Science, they believed, was a means towards a better and more efficiently governed and organized world. For science was disinterested and they supposed that those who produced it - scientists - stood at the pinnacle of a pyramid of disinterestedness. ${ }^{13}$

Still, if they agreed that the scientist stood at the pinnacle of a pyramid of disinterestedness, each also held that his nation stood at the pinnacle of the pyramid of Western civilization. In each case the promotion of a scientific international language served to sustain and/or establish its leading role in the international community. In chapter I we saw that Forman also emphasizes the centrality of the nation in scientific internationalism. He does this by comparing its dynamics with the Olympic Games, claiming that just like athletes competing for Olympic honors, scientists cooperate internationally (or seek to advance international cooperation) to gain praise from competing nations. ${ }^{14}$ This mechanism of international competition played a central role in the promotion of international language to the extent that the three protagonists acted in the interest of their home nations.

But with the exception of Ostwald, the protagonists themselves did not see their linguistic internationalism as an act of competing for international honors. Couturat's involvement with Ido was meant to showcase France's superiority as a leader in international civilization. But this reputation could not be won. In his eyes it simply belonged to France to begin with. As a representative of a privileged culture, Couturat saw upholding his nation's traditional position as his moral duty. Cottrell's conception of linguistic internationalism resembled Couturat's in that it was not about winning international acclaim, but about living up to a sense of duty - however strategic the interests - of fostering a more stable international community. In Cottrell's eyes Europe lay at the mercy of the 'benevolence' of the US. Like about half of his fellow countrymen (the other half voted against American participation in the League), he considered it his duty to guide Europe into a new world by organizing it "de novo". Finally, Ostwald articulated a more explicitly competitive notion of scientific internationalism. His organizational reform program was meant to contribute to the international expansion of the German empire. In doing so, his intention was to displace what he referred to as a Latin- dominated world culture.

\footnotetext{
${ }^{13}$ Cf. Forman, Paul (2010). '(Re)cognizing Postmodernity: Helps for Historians - of Science Especially,' Ber. Wissenschaftgesch (33): pp. 157-175. p. 163.

${ }^{14}$ Ibid. p. 154.
} 


\subsection{Fostering nationalism through language}

The diverging interests and narrow character of the three international language programs contradicts our protagonists' claim that their scientific language was interest-free and therefore neutral. They did not by-pass or transcend the pursuit of national and professional identity politics in creating and promoting a language through science. Instead, their campaigns were the expression of such politics to the core. In each case language was a vehicle for furthering the interests of specific professional, national and regional communities. These interests were a product of pre-exististing political situations that were typical of that period and of the specific communities in which our protagonists operated. This goes to show that the idealist image of scientists and their products as not only floating above political rivalries, but also above political interests and status enhancement, is a myth.

But while the ideal of scientists as politically neutral is a myth, it is a remarkably persistent one. In chapter I I pointed out that it has continued to show up time and time again and that the ISS can be seen as one of the latest incarnations of the idea that scientists cooperate harmoniously and that they serve no other interest than the interests of mankind as a whole. The view that scientific practices are truly global and universally beneficient can be described as an enduring value. But how can the ideal of scientists' political neutrality and ideological unity be maintained if in reality ideological and political diversity prevails? A possible answer to this question can be found in the function of myths as a strategy of contructing a communal sense of ideological unity.

Several studies have paid attention to the function of such values as builders of scientific community. By studying an American group of particle physicists, anthropologist Sharon Traweek, for instance, has shown that shared values play a role as "mythologies" which serve to define and bond the members of their community. ${ }^{15}$ But on the whole, the function of values as a means of building ideological cohesion remains underexpolored. Lorraine Daston has underlined the importance of gaining more knowledge on the function of scientific values in order to understand "what makes scientists as a group similar to and yet distinct from the larger cultural contexts that sustain them". ${ }^{16}$

While historians of science are generally not accustomed to viewing myths as a means to construct cohesion and kinship, such an approach has become conventional for contructivist historians of nationalism. ${ }^{17}$ As pointed out in the introduction of this chapter

\footnotetext{
${ }^{15}$ Traweek, Sharon (1992). Beamtimes and Lifetimes: The World of High Energy Physicists. Cambridge: Harvard University Press.

${ }^{16}$ Daston, Lorraine (1990). 'Nationalism and Scientific Neutrality under Napoleon,' in Frängsmyr, Tore (ed.), Solomon's House revisited: The Organization and Institutionalization of Science, pp. 95-115. Canton, MA: Science History Publications. p. 114.

${ }^{17}$ Notable exceptions are: Jordanova, Ludmilla (1998). 'Science and Nationhood: Cultures of Imagined Communities,' in Cubitt, G. (ed.), Imagining Nations, 192-211. Manchester: Manchester University Press. And: Jessen, R. and J. Vogel. (2002). 'Einleitung. Die Naturwissenschaften und die Nation. Perspektiven einer Wechselbeziehung in die Europäische Geschichte,' in R. Jessen, and J. Vogel (eds.), Wissenschaft und Nation in
} 
they approach nations as distictly modern social entities that are constructed through the political campaigning of a shared identity. They do this by stressing the elements of myth, artifact and social engineering that are involved in the making of national communites, in a process that entails endowing their past and present with idealized qualities and values.

To emphasize the constructed nature of this shared identity, Benedict Anderson has coined the canonical term "imagined community". Anderson made clear that what connects the members of a national community is a largely imagined mental image of their kinship that prevails over ideological differences and conflicts within nations. It is this imagined fraternity that makes it possible for nations to exist: "Regardless of the actual inequality and exploitation that may prevail in each [community], the nation is always conceived as a deep, horizontal comradeship" ${ }^{18}$

Crucially, Anderson and other seminal constructivist historians have pointed the central role played by language in the construction of imagined communities. From about the beginning of the nineteeth century onwards, they argue, a common language became one of the primary symbolic markers of national community. Nations were defined by a shared language, even if that language still had to be made through processes of linguistic standardization.

I argue that our protagonists copied the nationalist strategy of mobilizing language, and used it to foster a sense of communal identity at an international level. I will develop this argument in the rest of this chapter, but in this paragraph I set the stage for it by stringing together insights from several prominent constructivist historians of nationalism on the role of language in the building of nations. In doing so I show how language became one of the principal vehicles for nation contruction. ${ }^{19}$ More importantly, I identify the basic arguments and strategies used by nationalists, as they were exhibited by French and German agitators. It will appear in the next section that the community building tactics of our internationalist protagonists drew upon both these French and German nationalist strategies.

Constructivist historians point out that language only became a marker of communal identity with the emergence of the nation-state during the nineteenth century. They indictate that such a notion of language was not the norm before. ${ }^{20}$ Patrick J. Geary,

der Europäischen Geschichte, pp. 7-37. Frunkfurt: Campus Verlag.

18 Anderson, Benedict (2006). Imagined Communities: Reflections on the Origin and Spread of Nationalism. London/New York: Verso Books. p. 7.

${ }^{19}$ To be clear, this reconstruction of the emergence and machinations of nineteenth-century linguistic internationalism is not intended as a complete representation of the vast body of literature that exists on the subject. The aim is to highlight the similarity of this nationalist strategy with the early-twentieth-century attempts of our protagonists.

${ }^{20}$ Other scholars point out that multilingualism was more common than monolingualism before the eighteenth century for the European middle and upper classes. State officials, intellectuals, and monarchs usually spoke multiple languages. Frederick II, Holy Roman Emperor, was more fluent in Italian than in German. Emperor Charles V was famously quoted as boasting: 'I speak Spanish with God, Italian to women, French to men and German to my horse.' And Frederick the Great, the King of Prussia from 1740 to 1786, was 
for instance, argues that in the Roman Empire regional populations were united by social stratum, "not by language, custom, or law" and that, in the later Christian period, "all of society was unified by a single faith". ${ }^{21}$ Similarly, Hobsbawm suggests that before the national era, language was not more important than any other criteria for designating one's belonging to a certain community. He points out that centralized empires also operated through standardized languages, but these remained a form of elite communication. Most people simply did not read or write so for them it did not matter what the official language was. The function of language was, above all, to mark a disctintion between the elite and the rest of the people.

In the nineteenth century, with the rise of nationalism, language became the prime community builder. From about 1830, Hobsbawm argues, nationalists started to present language as "the soul of the nation" and increasingly used it as "the crucial criterion of nationality". ${ }^{22}$ By the end of the century linguistic nationalism had taken a hold of the entire European continent. As the renowned linguist Antoine Meillet observed in 1918: “L'Europe actuelle appartient aux langues nationales. (...) Le trait qui domine le développement linguistique depuis le début du xixe siècle est la fixation des langues nationales. Toute nation qui prend conscience d'elle-même veut avoir sa langue écrite, sa langue de culture qui lui soit propre". ${ }^{23}$

Constructivist historians of nationalism agree that the conception of language as a marker of nationhood was modeled after French cultural politics since the Revolution. French revolutionaries drew on older traditions of purifying and standardizing language that were embedded in the Académie Française. It had long pursued a policy of ridding French from obsolete words, dialecticisms and neologisms. ${ }^{24}$ French revolutionaries and their Republican successors continued this tradition, but in contrast to the Academy's program their intent was not scholarly; they mobilized French to create a centralized nation that shared its resources among all citizens who would come to view themselves as similar in language and in culture.

Early-nineteenth century French nationalists mobilized the myth of the Babylonian confusion of tongues to call attention to the wild growth of languages that urgently needed weeding. But the wild growth they were referring to was not the profusion of national languages, that Couturat later took issue with, but the plethora of local dialects, or patois.

\footnotetext{
ardently francophone-it was even said that he was more fluent in French than in German. In fact, in Frederician Berlin the majority of the intellectuals subscribed to the view that their own language was inferior to French. In some cases foreign languages held entire institutions together. The official language of the Danish army was German until 1773. Braunmüller, Kurt. \& Ferraresi, Gisella (eds.) (2003). 'Introduction,' in Braunmüller, Kurt. \& Ferraresi, Gisella (eds.), Aspects of Multilingualism in European Language History, pp 17. Amsterdam: John Benjamins Publishing Co. p. 1.

${ }^{21}$ Geary, Patrick J. (2003). The Myth of Nations: The Medieval Origins of Europe. Princeton: Princeton University Press. p. 140.

22 Hobsbawm (nr. 1), Nations and Nationalism Since 1780: Programme, Myth, Reality, p. 95.

${ }^{23}$ Meillet, Antoine. (1918). Les Langues dans l'Europe Nouvelle. Paris: Payot \& Cie. pp. 188-189.

${ }^{24}$ Ayress-Bennett, Wendy (1996). A History of French Through Texts. New York: Routledge. p. 10.
} 
Their aim was to supplant these with a single, standardized French. A typical exponent of this agenda was the revolutionary leader and Roman Catholic priest Henri Grégoire (17501831). In his address to the National Convention on "the need and means to eradicate patois and to universalize the use of the French language", Grégoire argued that: "With thirty different local dialects, we are still, as regards language, at the Tower of Babel, whilst as regards liberty we form the avant-garde of nations. [We must] make uniform the language of a great nation, so that all its citizens can without hindrance communicate their thoughts to each other". ${ }^{25}$

But how exactly did the French nationalists mobilize language to contruct, or invent, a national identity? Grégoire's interest in the adoption of French went beyond enabling people to communicate with each other "without hindrance". His objective was to construct a nation that was unified by an ideology of rational patriotism and he used French as a means to circulate and disseminate this idea. He did this by presenting the French language as a unique expression of the values and virtues that formed the core of $/ a$ grande nation:

Such a project [of making uniform the language], which no nation has yet fully accomplished, is a worthy one for the French people, who are in the process of centralizing all the branches of social organization and who should be concerned, in a Republic one and indivisible, to establish as soon as possible the language of liberty as the one and only language. ${ }^{26}$

Grégoire's use of French is illustrative of how French nationalists appropriated language as an ideological marker to foster national identity. But as Grégoire's emphasis on French as a worthy language for a great nation indicates, French nationalists also mobilized French to construct and promote an image of their nation as a cultural leader in Europe. A particularly strong manifestation of this policy was the linguistic nationalism of Count Antoine de Rivarol.

In chapter II I mentioned de Rivarol's essay "On the Universality of the French Language" in order to identify the historical roots of Couturat's promotion of Ido as a superior language for international communication. We saw that Couturat adopted a similar position on Ido as de Rivarol on French. It is relevant to turn once more to de Rivarol's essay, this time to illustrate how (from a constructist perspective) he mobilized French to construct an ideologically unfied French nation whose citizens viewed themselves as the proud inhabitants of the leading nation of Europe.

The first step of de Rivarol's strategy was to dismiss rivalling national languages as expressions of outdated and worn-out cultures. De Rivarol argued that German was old-

\footnotetext{
${ }^{25}$ Cited in, Grillo, Ralph D. (1984). Dominant Languages. Cambridge: Cambridge University Press. p. 24. ${ }^{26} \mathrm{Ibid}$.
} 
fashioned, "too rich and too hard". ${ }^{27}$ Spanish, he claimed, was too pompous and its past gallantry had turned dark with the decline of the Golden Age. Italian received a slightly more favorable review, because de Rivarol considered it as the language of his ancestors. Yet he argued that just like Spanish, Italian lost its authority after the sixteenth century when Italy entered a period of political conflicts.

The second - and most important - step of de Rivarol's strategy was to present newly standardized French as possessing everything that German, Spanish and Italian lacked. He claimed that it was by far the most regular, precise and logical language that existed. In doing so he not only presented French as an expression of the key values of the Enlightenment; he claimed that these values were itself an expression of what it meant to be French:

\begin{abstract}
What distinguishes our language from ancient and modern languages is the organization and construction of its sentences. This organization must always be direct and of necessity clear. A Frenchman begins by naming the subject of any speech, then the verb which expresses the action, and lastly the object of this action: here is the logic natural to all men... THAT WHICH IS NOT CLEAR IS NOT FRENCH; that which is not clear remains English, Italian, Greek or Latin. ${ }^{28}$
\end{abstract}

De Rivarol's message was clear: the newly standardized French language exhibited unique qualities and these were a direct expression of French identity. By claiming this, he used language as a signpost and a reminder of what it meant to be French. As a result, the users of French became connected through the narrative of communal distinctiveness that it reprented.

De Rivarol's essay is also illustrative of how French nationalists mobilized language to foster a sense of historical kinship among its users by promoting it as a link between them and a distant, idealized past community. Geary summarizes this contructivist strategy as the creation of the myth of a unique cultural heritage "proving the existence of discrete 'linguistic communities' sharing the same vision of life, the same social and religious values". ${ }^{29}$ De Rivarol contributed to the construction of such a heritage for the rench by claiming that newly standardized French was a derivative of Latin. To highlight the cultural value of this Latin connection, he reminded his French contemporaries that Latin's implementation went back to glory days of the Roman conquest. In other words, French was supposed to remind it users - no matter where they were from - of their Roman

\footnotetext{
${ }^{27}$ de Rivarol, Antoine (1797). De l'Universalité de la langue Française. Paris: chez Cocheris, Imprimeur-Libraire. p 4. [my translation].

${ }^{28}$ Ibid. p. 34.

${ }^{29}$ Geary (nr. 21), The Myth of Nations: The Medieval Origins of Europe, p. 32.
} 
lineage.

De Rivarol also pointed out that French was much more than a derivative of Latin, which he claimed had become corrupted by "barbaric" languages after the demise of the Roman Empire. The adoption of French marked a return of the cultural purity the Romans exhibited in their heyday. In other words, the standardization of modern French signaled nothing less than a revival of Roman Empire in the form of a unified and proud French nation.

The notion of language as a marker of nationality was also developed in a slightly later tradition, that of German romanticism. This tradition was another important resource upon which our liguistic internationalists would later on draw, and hence it warrants a closer look as well. German romanticism was a reaction against Enlightenment rationalism and an expression of a rising fear of Napoleon's conquest of Europe. ${ }^{30}$ This sentiment spurred a passionate linguistic nationalism in Germany among several romantic intellectuals, including Wilhelm von Humboldt (1776-1835), Johann Gottlieb Fichte (1762$1814)$ and the brothers Jacob (1785-1863) and Wilhelm (1768-1859) Grimm. The German nationalists strategically mobilized the French argument to their own advantage by claiming that the need to homogenize and purify language indicated that there never was an authentic French nation to begin with. Johann Gottfried Herder (1744-1803) had already argued in the eighteenth century that an authentic sense of nationhood could never be imposed from above by a state. For Herder a true nation was identical with a unique Volksgeist, a spirit of the people that had existed for centuries.

Von Humboldt elaborated Herder's notion of Volksgeist by stressing that a native language was a unique expression of this soul. His claim was that in contrast to standardized French, German had organically developed over centuries as it served more or less the same community, which suggested that there was a profound relationship between the Germans and their language that could never be created by imposing a language. To further promote a shared sense of kinship between Germans, von Humboldt claimed that only those who spoke German could access the hidden essence of their nation.

Fichte even claimed that the key to igniting a sense of German pride was to be found in the reappraisal of the German language. His Reden an die deutsche Nation (18078), which was clearly designed to produce a proud nation, outlined a program of national education that was meant to make the Germans realize their potential as the representatives of a leading culture. Starting from the assumption of the purity and integrity of the German language, he attempted to fashion a sense of German superiority by arguing that it could preserve culture better than any other language. He did this by claiming that Germany contributed to the betterment of Western civilization because it possessed qualities that partook in a pre-modern, original entity. These qualities were

\footnotetext{
${ }^{30}$ Oakes, Leigh (2001). Language and National Identity: Comparing France and Sweden. Amsterdam: John Benjamins B.V. p. 22
} 
supposedly a vital antidote for the modern problems of selfishness and division.

Like Rivarol, Fichte turned to the Romans to construct a sense of historical kinship with a community from the distant past. He based this connection on Germania, a famous ethnographic account of Germanic tribes outside the Roman Empire by the Roman senator and historian Tacitus. It provided German nationalists with an ideal document for the invention of a shared historical identity. Germania offered all the ingredients to paint a picture of a virtuous people, enabling them to favorably contrast Germanic simplicity with Roman degeneracy. The fact that any direct comparison between Rome and Germania is not explicitly present in the text was irrelevant. ${ }^{31}$ Neither was it relevant that Tacitus offered a heterogeneous picture of the Germans and that he pointed out that they actually spoke in different tongues. The point is that to construct and foster a sense of unity and national pride, German nationalists distilled those elements from Germania that exaggerated and emphasized the virtues of the Germans.

The work and success of the brothers Jacob and Wilhelm Grimm, German academics, mythologists, linguists and lexicographers, propelled this trend of cultural nationalism. They pieced together folklore and poetry in books such as Deutsche Mythologie and more famously Grimm's Fairy Tales, which stimulated and glorified the traditions that nationalists like von Humboldt and Fichte had helped to invent. Jacob Grimm continued to define and idealize Germanness with particular reference to language, stating, "daß einem Volk, daß über Berge und Ströme gedrungen ist, seine eigene Sprache allein die Grenze setzen kann". ${ }^{32}$ He also contributed to the institutionalization of German by documenting its grammar in his book Deutsche Grammatik and by finishing a monumental dictionary of the German language.

Paralleling the efforts of the brothers Grimm, there was a surge of national grammars, dictionaries and periodicals in other European countries too. This development went hand-in-hand with a rapid institutionalization of the history of literature, or philology. Literature and history began to play a central role in public life as providers of national myths that were disseminated through nationally standardized educational systems. These fostered and enriched the narratives of cultural kinship and in many cases of the superiority of one's national culture vis-à-vis other national cultures. Grégoire, de Rivarol and the German nationalists were the pioneers of this general trend of cultural nationalism. It was through the institutionalization of a single national language, coupled with assertions about their supposedly inherent qualities, virtues and links with past traditions, that a 'real' and 'natural' national consciousness could emerge.

\footnotetext{
${ }^{31}$ Mees, Bernard T. (2008). The Science of the Swastika. Budapest/New York: Central European University Press. p. 34.

${ }^{32}$ Cited in, Kluckhohn, Paul (1961). Das Ideengut der deutschen Romantik, 4th edn, Tübingen: Niemeyer. p. 113.
} 


\subsection{Fostering internationalism through language}

How do these strategies by nationalist agitators relate to the early-twentieth century attempts by scientists to promote international language? As pointed out, our protagonists' attempts were set in the period when the institutionalization of language as a marker of nationality held Europe in its grip. They claimed to strive to overcome this multitude of national languages and criticized the national chauvinism exhibited by nationalists. As such, their pursuit appears as the reverse of de Rivarol's and Fichte's program and its emphasis on the authority of the mother-tongue as an expression of the supremacy of the home nation. To quote Couturat: "If any one is the victim of national prejudice it is he who proposes his own language as the international medium, and not the one who discards every national tongue, including his own, in favor of the international language". ${ }^{33}$ Couturat's language was unique because it belonged to the whole world. He, Ostwald and Cottrell repeatedly emphasized that its neutral character made it ideally suited for an efficient and unbiased communication between nations as opposed to for nations.

Paradoxically, however, from a social constructivist perspective, the campaigning of our protagonists bore a close resemblance to the campaigning of nationalists who mobilized language. Like the nationalists, who contrasted their language with local dialects and with other national languages to claim its superiority, our protagonists argued for the superiority of their language over national languages. Like the nationalists, they exaggerated and highlighted the confusion of tongues caused by language multiplicity. And like the nationalists, they promoted the alleged multitude of languages as a symbol of the fragmented state of their community that supposedly needed unification through the introduction of a single and superior language. In both cases, the strategy was to promote language as a unique expression of the values and qualities of a community. As such, language not only served as a practical tool to connect the members of this community; it also served as an ideological marker of the values and qualities that distinguished it from other communities, thereby binding its members them together.

Our protagonists also copied nationalists' strategies on a practical level. This can be seen, for example, in the use of dictionaries and lexicons to institutionalize the new language as a standard for scientific communication. Just like Jacob Grimm, who sought to institutionalize national language by publishing Deutsche Grammatik and a German dictionary, Couturat published several international dictionaries as well as a lexicon of mathematical concepts in Ido. Similarly, Ostwald translated the periodical table of elements into Ido in an attempt to promote its use by his peers in physical chemistry.

The same practice of copying strategies from nationalists for internationalist purposes can also be discerned in non-linguistic forms of scientific internationalism. Otlet and Lafontaine's project to build an international archive that housed the world's

\footnotetext{
${ }^{33}$ Couturat, Louis (1905). 'An International Auxiliary Language,' Monist 15: 142-146. p. 6.
} 
knowledge (see chapter I) mirrored the earlier creation of national archives as containers of the nations's heritage and identity. In the process they also replaced national classicfication guidelines with an international system. Similarly, Sarton used the history of science in order to show the unity of mankind. His program was modeled on the nineteenth century tradition of heritage as a fosterer of a sense of national identity - but now taken to the highest level: humanity in its entirety. ${ }^{34}$

What is especially interesting about our linguistic internationalists is that they used language not only as an instrument for communication, and hence direct community building, but also as a carrier of values and qualities that were deemed characteristic of the scientific community. Even in this they followed nationalist strategies. As we have seen Rivarol argued that the French language reflected the natural tendency of its users to be rational and precise. This tendency towards rationalism and precision allegedly distinguished the French from and placed them above members of other cultures. Similarly, our protagonists claimed that the rational character of Ido reflected the rationality of science and the scientific community. By highlighting the precision, rationality and neutrality of their language, they transmitted the idea that scientists shared these unique and superior qualities. The message: scientists are different from ordinary citizens in that they possess an exceptional and characteristic tendency towards rationalism, cooperation and neutrality.

We saw that de Rivarol promoted the idea that the French had given birth to the Enlightenment by endowing their new language with the above-mentioned values of rationality, precision etc. Our protagonists also copied this strategy, making clear that scienists - and not the French or any other people - were the true heirs of the Enlightenment. In fact, they mimicked de Rivarol's strategy of mobilizing French as a revival of cultural purity of the Romans, in that the international language of our protagonists symbolized a revival of the cosmpolitanism and interest-free cooperation it once displayed in the form of the idyllic Republic of Letters. Moreover, like de Rivarol's French, the language of our protagonists symbolized a return of Latin - albeit in a modern guise. In doing so, they referred to an equally idealized but different 'Latin'. De Rivarol presented French as marking a return of the cultural unity and vitality of the Roman Empire. The language of our protagonists symbolized a return of the politically disinterested transfer of knowledge that Latin was claimed to have facilitated during the Republic of Letter (so before the emergence of nationalism corrupted the cosmopolitan and harmonious character of cooperation among scientists).

At first sight the strategic parallels between our protagonists and German nationalists in terms of the use of language to contruct community are more difficult to

\footnotetext{
${ }^{34}$ Somsen, Geert (2013). 'Wetenschap als Werelderfgoed. George Sartons Internationalistische Geschiedschrijving,' in Huisman, Frank \& Randeraad, Nico \& Georgi Verbeeck (eds.), Geschiedenis is Overal, pp. 104-121. Amsterdam: Wereldbibliotheek.
} 
identify. We saw that German nationalists endowed German with qualities that stood in opposition to the Enlightenment tradition. What made the Germans a shining example of a unified people, they argued, was that history revealed that they had possessed the same language for centuries. And during this period German had grown organically with its users, which made it an authentic and a timeless expression of Germanness. So for German nationalists the opposition between German and French therefore boiled down to authenticity versus artificiality. The language of our protagonists clearly fell in the category "artificial" (our protagonists themselves emphasized that its artificial character placed it above national languages as a vehicle for the international transfer of knowledge).

From a contructivist point of view, however, the distinction "natural vesus artificial" was itself artificial. As Hobsbawm makes clear, there is no inherent difference between national languages and artificial languages: "National languages are (...) almost always semi-artificial constructs and occasionally, like modern Hebrew, virtually invented". ${ }^{35}$ Claims on the primordial or assembled character of language were expressions of the same process of constructing and asserting virtues and qualities of the communities it represents. The supposed ancient and primordial character of German (and therefore the German culture it was supposed to be an expression of) distinguished it from the more modern, rational identity the French had constructed for themselves. Similarly, the scientifically assembled character of our protagonists' language (which made it politically disinterested) was supposed to distinguish it from national languages (and thereby from the identity of the cultural communities they represented) in the same way German was mobilized to demarcate the distinctiveness of the Germans.

But in addition to using of language as a means to foster communal identity through the politics of difference, our protagonists exhibited a strategy of building into its users a sense of priviledge and authority that resembled the strategy pursued by German nationalists. We saw that German nationalists connected its users to a kind of primordial past that was untainted by modernity, which was presented as the key to overcoming what Fichte et al. perceived as the modern perils of fragmentation and a loss of a spiritual sense of belonging to a distinct community. Similarly, our protagonists presented their language as a sort of therapeutic ailment for man's struggle with modernity. But instead of representing a return of some kind of primordial entity as a cure, their language was supposed to help the individual to process the rapid advances of modern science and technology. It did this by providing its users access to something that was just as special (perhaps even more so) than a primordial and mystical spirit, namely the timeless realm of objective knowledge.

\footnotetext{
${ }^{35}$ Hobsbawm (nr. 1), Nations and Nationalism Since 1780: Programme, Myth, Reality, p. 54.
} 


\subsection{Real imaginations}

In chapter I I pointed out that current studies on internationalism tend to sustain the myth of internationalism. These studies paint a picture of international movements as an expression of a genuinely new and positive political agenda that turns its back on the nation by seeking cooperation for the benefit of all. In the previous chapters I showed that scientific internationalism, often regarded as the most pristine variety of internationalism, was an expression of diverging personal and national agendas. Moreover, in this chapter I nuanced the distinction between nationalism and internationalism on another level by pointing out that our protagonists' fostered a sense of community on an international level in a typically nationalist fashion.

Like national communities, international communities can be studied as imagined communities. The consistency and ideological cohesion of the political agenda of scientific internationalists - both in the present and the past - was more imaginary than real. Benedict Anderson argues that this imagined character of communal identities is exactly what makes it an effective community builder. A sense of national kinship requires the invention and constant articulation of characteristics and values that are supposed to connect members of a nation. Nations can exist, he points out, because myths of racial bonding and a common heritage create a real sense of belonging among its citizens. Our protagonists also fostered such a sense of imagined comradeship by promoting the scientific international language. As such, its function was to remind its users of their professional camaraderie as well as of the glorious history that came with it in the same way nationalist agitators mobilized language to contruct the imaginary comradeship across distance and time that glued nations together.

The construction of a sense of comradeship across distance and time - both on a national and an international level - requires myth making. Hobsbawm points out that "Nationalism requires too much belief in what is patently not so. As Renan said: 'Getting its history wrong is part of being a nation'" ${ }^{36}$ This mechanism of inventing history can be clearly illustrated by the nationalist appropriation of Tacitus' Germania. Nationalists called it the "golden booklet" because it described the Germans as a people of solid values, untainted by corruption and intermarriage with other nations. In doing so they neglected that Germania also presented a multifarious picture of the Germans. Tacitus not only reported that Germany consisted of more than fifty separate tribes. He also described plenty of appalling 'German' qualities that never made it into the nationalist repertoire of German characteristics. ${ }^{37}$ Instead, only those elements in Germania that underline the virtues and unity of German culture were emphasized.

\footnotetext{
${ }^{36}$ Ibid, p. 12.

${ }^{37}$ For further reading on the how Germania was exploited by German nationalists see, Krebs', Christopher B. (2011). A Most Dangerous Book: Tacticus's Germania from the Roman Empire to the Third Reich. New York: W.W. Norton \& Company.
} 
Science's glorious past of harmonious cooperation was - and is - no less conveniently tailored to advocate the cultural unity and continuity of what we call the scientific comunity. Our scientific internationalists, for instance, idealized the past for the sake of emphasizing scientists' shared virtues. This was perhaps most clearly visible in Couturat's celebration of Leibniz as a true scientific internationalist who sought to connect China with Europe through the Characteristica universalis. By suggesting that Leibniz's ideological ambition was to facilitate international cooperation, Couturat presented Leibniz as exhibiting the qualities and virtues he believed any respectable early-twentieth-century scientist was supposed to exhibit, namely national disinterestedness and an inclination towards international cooperation. He implied that scientists preserved these values since the Enlightenment. We saw, however, that from a historical perspective Leibniz's ideological program was not at all the same as Couturat's ideological program. Leibniz's language project was driven by a typically seventeenth century notion of Christian universalism that went hand-in-hand with the ambition of converting the Chinese to Christianity.

In the same way that national languages connect their users to an imagined past, the scientific international language was a reminder of an imagined tradition of science's internationalism. Benedict Anderson points out that language is particularly effective as a transmitter of a sense of kinship across time:

\begin{abstract}
(...) nothing connects us affectively to the dead more than language. If English-speakers hear the words 'Earth to earth, ashes to ashes, dust to dust - created almost four-and-a-half centuries ago - they get a ghostly imitation of simultaneity across homogeneous, empty time; it comes also from as as-it-were ancestral 'Englishness'. ${ }^{38}$
\end{abstract}

Like English, the international language of our protagonists was an aide-mémoire of science's illustrious past that conjured up romantic images of the exemplary cosmopolitanism and disinterestedness of the Republic of Letters. Even if their project in the end was largely a failure, it did leave the impression that there had been times when scientists did form a harmonious community - a golden age of scientific internationalism.

Our familiarity with the narrative of scientists as standing in a long tradition of exemplary internationalism is a testimony of the power of this imagined ideal. But in contrast to most national identities, the narrative of scientific internationalism is not sustained through a standardized vernacular. Since World War II English has risen to become the dominant language in the international scientific community, but science continues to be conducted in many national languages. These languages transmit stories of

\footnotetext{
${ }^{38}$ Anderson (nr. 18), Imagined Communities, p. 149.
} 
scientists' glorious history as exemplary internationalists across distance and time in the same way that national heritages are communicated through multiple languages in multilingual nations such as Switzerland and Belgium. As idealized fragments of the past, these stories are articulated time and time again because they provide scientists with prestige and authority. They function as ideological cement that continues to hold the scientific community together. 



\section{REFERENCES}

Augspurger, Michael (2004). An Economy of Abundant Beauty: "Fortune" Magazine and Depression America. Cornell: Cornell University.

Ager, Dennis A. (1998). Language Policy in Britain and France: The Processes of Policy. London/New York: Continuum International Publishing Group.

Akin, William E. (1977). Technocracy and the American Dream: The Technocrat Movement, 1900-1941. Berkeley and Los Angeles: University of California Press.

Anderson, Benedict (2006). Imagined Communities. London/New York: Verso Books.

Anderson, Perry (2002) 'Internationalism: A Breviary,' New Left Review (14): pp. 5- 25.

Retrieved from the Worldwide Web on October $10^{\text {th }}, 2011$ :

http://newleftreview.org/II/14/perry-anderson-internationalism-a-breviary

Ausubel, Jesse H. \& Keynan, Alexander (2001). 'Foreword: the history of scientists' roles in international conflict resolution,' in Ausubel, Jesse H., Keynan, Alexander, and Salomon, Jean-Jacques (eds.), Technology in Society Special issue, Scientists, Wars and Diplomacy: A European Perspective (23)3: pp. 287-289.

Ayress-Bennett, Wendy (1996). A History of French Through Texts. New York: Routledge. Baghramian, Maria (2004). Relativism. Oxfordshire: Routledge.

Baume, Andreas (2009). Fortschritt als Ideologie: Wilhelm Ostwald und der Monismus. Leipzig: Leipziger Universitätsverlag.

Bender, Thomas \& Geyer, Michael (2010). 'Empires: Might and Myopia,' in Mauch, Christof \& Patel, Kiran Klaus (eds.), The United States and Germany During the Twentieth Century: Competition and Convergence, pp. 13-31. Cambridge: Cambridge University Press.

Braunmüller, Kurt. \& Ferraresi, Gisella (eds.) (2003). 'Introduction,' in Braunmüller, Kurt. \&

Ferraresi, Gisella (eds.), Aspects of Multilingualism in European Language History, pp. 1-

7. Amsterdam: John Benjamins Publishing Co.

Brisson, Jeffrey (2005). Rockefeller, Carnegie, and Canada: American Philanthropy and the

Arts and Letters in Canada. Montreal: McGill-Queens University Press.

Burkman, Thomas W. (2008). Japan and the League of Nations: Empire and World Order, 1914-1938. Honolulu, HI: University of Hawaii Press.

Bush, Vannevar (1949). 'Frederick Gardner Cottrell: 1877-1948,' Science (110)2863: pp. 497-498.

Cameron, Frank (2004[1952]). Cottrell: Samaritan of Science. Tuscon, Ariz: Research Corporation.

Canto-Sperber, Monique (2008). Moral Disquiet and Human Life. Princeton: Princeton University Press. 
Chabard, Pierre (2008). 'Towers and Globes: Architectural and Epistemological Differences between Patrick Gedde's Outlook Towers and Paul Otlet's Mundaneums,' in Rayward, W. Boyd (ed.), European Modernism and the Information Society: Informing the Present, Understanding the Past, pp. 105-126. Alderschot, UK: Ashgate Publishing.

Chickering, Roger (1993). Karl Lamprecht: A German Academic Life (1856-1915). Atlantic Highlands, NJ: Humanities Press International, Inc.

Churchill, Winston (1943). 'The Price of Greatness is Responsibility,' Harvard speech given at the occasion of receiving an honorary Doctor of Laws degree. Available on the website of The Churchill Centre and Museum at the Churchill War Rooms, London. Retrieved from the World Wide Web on September $10^{\text {th }}, 2012$ :

http://www.winstonchurchill.org/index.php?option=com_content\&view=article\&id=42 0\&Itemid $=32$

Crawford, Elizabeth. (1992). Nationalism and Internationalism in Science, 1880-1939: Four Studies of the Nobel Population. Cambridge: Cambridge University Press.

Cornell, Thomas D. (2004). Establishing Research Corporation. Tucson, Ariz: Research Corporation.

Cottrell, Frederick G. (1937). 'The social responsibility of the engineer,' Science (85)2214/2215: pp. 529-533 \& 553-556.

Cottrell, Frederick G. (1923). Report of Progress, August 1923. Committee on International Auxiliairy Language of the International Research Council.

Cottrell, Frederick G. (1920). 'Willard Gibbs Medal Award: Medal Address International Scientific Relations,' The Journal of Industrial and Engineering Chemistry (12)7: pp. 679700. p. 698.

Cottrell, Frederick (1918). Frederick Cottrell to Derek Walcott, March 29, 1918. Archive of the Research Corporation. Box 7, F. 82.

Cottrell, Frederick, G. (1912). 'The Research Corporation: An experiment in the public administration of patent rights,' Journal of Industrial and Engineering Chemistry (4)12: pp. 864-867.

Couturat, Louis (1911). 'Des Rapport de la Logique et de la Linguistique,' Revue de Métaphysique et de Morale (19)4: pp. 509-516.

Couturat, Louis (1910). 'On the Application of Logic to an International Language', in Couturat, L. \& Jespersen, O. \& Lorenz, R. \& Ostwald, W. \& Pfaundler. L. International Language and Science: Considerations on the Introduction of an International Language into Science, pp. 42-52. Translated by Donnan, F.G. London: Constable and Company Limited.

Couturat, Louis (1910). Internaciona Matematikal Lexiko. Jena: Gustav Fischer Editisto. Couturat, Louis (1909). Le Choix d’une Langue Internationale. Paris: Éditions de la Revue du Mois.

Couturat, Louis (1906). Pour la Langue Internationale. Coulommiers: Imprimerie Paul Brodard. 
Couturat, Louis (1905). 'Lecture inaugural, Collège de France,' in L'Oeuvre de Louis Couturat: de Leibniz a Russell, pp. 17-33. Paris: Presses de l'École Normale Supérieure. Proceedings of a conference.

Couturat, Louis (1905). 'An International Auxilairy Language,' Monist (15): pp. 142-146.

Couturat, Louis \& Leau, Leopold (1903). Histoire de la Langue Universelle. Paris: Librairie Hachette.

Couturat, Louis (1899). Letter by Couturat to Xavier Léon. September 27, 1899. From the correspondence by Xavier Léon. Bibliothèque Victor Cousin, housed at the Bibliothèque de la Sorbonne in Paris.

Couturat, Louis (1900). Letter by Couturat to Xavier Léon dated August $19^{\text {th }} 1900$. From the correspondence by Xavier Léon, Manuscrits de la bibliothèque Victor-Cousin.

Couturat, Louis (1900). Letter by Couturat to Xavier Léon dated September $25^{\text {th }} 1900$. From the correspondence by Xavier Léon, Manuscrits de la bibliothèque Victor-Cousin.

Couturat, Louis (1901). The Logic of Leibniz (chapter 3 ['The universal language', paragraph 3). Translated by Donald Rutherford. Retrieved from the World Wide Web on May 27th, 2012: http://philosophyfaculty.ucsd.edu/faculty/rutherford/leibniz/ch3.htm

Couturat, Louis (1901). La logique de Leibniz d'après des documents inédits. Paris: Ancienne Librairie Germer Baillière.

Couturat, Louis (1899). 'Correspondance,' Le Temps, March 27th.

Couturat, Louis (1893). 'Sur l'Évolutionnisme Et le Principe de la Conservation de L'Énergie,' Revue de Métaphysique et de Morale (1)6: pp. 564-527.

Darboux, Gaston (1901). 'L'Association Internationale des Académies,' Le Journal des Savants: 5-23.

Darrow, Karl (1943). 'Internationalism in Science', Science (28)2536: pp. 122-123.

Daston, Lorraine \& Galison, Peter (2007). Objectivity. New York: Zone Books.

Daston, Lorraine (1991). 'The Ideal and Reality of the Republic of Letters in the Enlightenment,' Science in Context (4)2: pp. 367-386.

Daston, Lorraine (1990). 'Nationalism and Scientific Neutrality under Napoleon,' in Frängsmyr, Tore (ed.), Solomon's House revisited: The Organization and Institutionalization of Science, pp. 95-115. Canton, MA: Science History Publications.

de Beer, Gavin (1960). The Sciences Were Never at War.

London/Edinburgh/Paris/Melbourne/Johannesburg/Toronto/New York: Thomas Nelson and Sons Ltd.

de Beaufront, Louis (1917). Ido-Guide (English-Ido) for Doctors, Nurses, Stretcher-Bearers, The Wounded, The Sick, Soldiers. Translated and adapted by H. Brisbane Eldon, president of the British Idistic Society. London: Blades, East \& Blades printers.

Deltete, Robert J. (2007). 'Wilhelm Ostwald's energetics 1: Origins and Motivations,' Foundations of Chemistry (9): pp. 3-56.

Deltete, Robert (1983). The Energetics Controversy in Late Nineteenth-Century Germany: Helm, Ostwald and their Critics, Volume II. Ann Arbor, Mich: University Microfilms International. 
Dickson White, Andrew (2012[1869]). A History of the Warfare of Science and Theology in Christendom: From the Creation to the Victory of Scientific and Literary Methods.

Piscataway, NJ: Transaction Publishers.

Eaton, H.S. (1936). Memorandum to Howard Poillon and Herbert Shenton from H.S. Eaton in recalls with Mr. Stevens of R.F.. March $11^{\text {th }}, 1936$. Archives of the Research Corporation. Box 7, F. 82.

Eco, Umberto (1995). The Search for the Perfect Language. Oxford: Blackwell Publishers. Esterhill, Frank J. (2000). Interlingua Institute: A History. New York: Interlingua Institute. Falk, Julia (1999). Women, Language and Linguistics: Three American Stories from the First Half of the Twentieth Century. London: Taylor \& Francis Group.

Fenves, Peter (2005). 'Imagining an Inundation of Australians; or, Leibniz on the Principles of Grace and Race,' in Valls, Andrew (ed.), Race and Racism in Modern Philosophy, pp. 73-88. Ithaca, NY: Cornell University.

Feuz, Patrick \& Tobler, Theodor (2001). 'Theodor Tobler (1876-1941): Selfmademan, Patron, Pazifist,' in Leimgruber, Yvonne (ed.), Chocolat Tobler: zur Geschichte der Schokolade und einer Berner Fabrik; Begleitpublikation zur Ausstellung "Chocolat Tobler - Eine Dreiecksgeschichte. Von 1899 bis heute" im Kornhaus Bern. pp. 81-89. Bern: Historisches Institut der Universität Bern.

Forman, Paul (2010). '(Re)cognizing Postmodernity: Helps for Historians - of Science Especially,' Ber. Wissenschaftgesch. (33): pp. 157-175.

Foreman, Paul (1973). 'Scientific Internationalism and the Weimar physicists: The Ideology and its manipulation after World War I,' Isis 64(2): pp. 151-180.

Forster, Peter G. (1982). The Esperanto Movement. Den Haag: Mouton Publishers.

Geary, Patrick J. (2003). The Myth of Nations: The Medieval Origins of Europe. Princeton:

Princeton University Press.

Geyer, Martin (2001). 'One Language for the World: The Metric Sytem, International Coinage, Gold Standard, and the Rise of Internationalism, 1850-1900,' in Geyer, Martin \& Paulmann, Johannes (eds.), The Mechanics of Internationalism, pp. 55-94. Oxford: Oxford University Press.

Geyer, Martin \& Paulmann, Johannes (2001). 'Introduction. The mechanics of internationalism,' in Geyer, Martin H. \& Paulmann, Johannes. (ed.), The Mechanics of Internationalism. Culture, Society, and Politics from the 1840 s to the First World War, pp. 1-26. Oxford: Oxford University Press.

Grillo, Ralph D. (1984). Dominant Languages. Cambridge: Cambridge University Press. Haber, Fritz (1902). Fritz Haber in seiner Korrespondenz mit Wilhelm Ostwald sowie Briefen an Svante Arrhenius. Berlin: ERS Verlag.

Hartley, Harold (1960). 'Science before the days of total war,' The New Scientist (7)177: p. 885. 
Hapke, Thomas (1998). 'Wilhelm Ostwald, the "Brücke," and Connections to Other Bibliographic Activities,' in Bowden, Mary E., Bellardo Hahn, Trudy, Williams, Robert V. (eds.), Proceedings of the 1998 Conference on the History of Heritage of Science Information Systems, pp. 139-147. Medford, NJ: Information Today.

Heynick, Frank (2002). Jews and Medicine: An Epic Saga. Hoboken, NJ: Ktav Publishing House, Inc

Hitler, Adolf (1943[1925]). Mein Kampf. München: Franz Eher Nachf. Verlag (Zentralverlag der NSDAP).

Hobsbawm, Eric (1992). Nations and Nationalism Since 1780: Programme, Myth, Reality. Cambridge: Cambridge University Press.

Holzberger, William G. (ed.) (2008). The Letters of George Santayana: 1948-1952, Book 8. Cambridge: MIT press.

Howes, John F. (ed.) (1995). Nitobe Inazō: Japan's Bridge Across the Pacific. Boulder, CO: Westview.

Iriye, Akira (2013). Global and Transnational History: The Past, Present and Future. New York: Palgrave Macmillan.

Iriye, Akira. \& Saunier, Pierre-Yvess (2009). 'The professor and the madman,' Introduction in The Palgrave Dictionary of Transnational History. Retrieved from the World Wide Web on September 14th, 2012:

http://www.transnationalhistory.com/about.aspx?id=1420

Iriye, Akira. (2004). Global Community: The Role of International Organizations in the Making of the Contemporary World. Berkeley and Los Angeles: University of California Press.

Iriye, Akira (1997). Cultural Internationalism and World Order. Baltimore, M: John Hopkins University Press.

Jensen, Derrick (2004). The Culture of Make Believe. White River Junction, VT: Chelsea Green Publishing.

Jessen, R. and J. Vogel. (2002). 'Einleitung. Die Naturwissenschaften und die Nation.

Perspektiven einer Wechselbeziehung in die Europäische Geschichte,' in R. Jessen, and

J. Vogel (eds.), Wissenschaft und Nation in der Europäischen Geschichte, pp. 7-37.

Frunkfurt: Campus Verlag.

Jordanova, Ludmilla (1998). 'Science and Nationhood: Cultures of Imagined Communities,' in Cubitt, G. (ed.), Imagining Nations, pp. 192-211. Manchester: Manchester University Press.

Kellermann, Hermann (1915). Der Krieg der Geister: Eine Auslese deutscher und ausländischer Stimmen zum Weltkriege 1914. Weimar: Verlag Vereinigung Heimat und Welt.

Kevles, Daniel. (1972). The Physicists: The History of a Scientific Community in Modern America. Cambridge: MIT press.

Kevles, Daniel (1971). "'Into hostile camps": The Reorganization of International Science in World War I,' Isis (62)1: pp. 47-60. 
Kluckhohn, Paul (1961). Das Ideengut der deutschen Romantik, 4th ed., Tübingen:

Niemeyer.

Knip, Karel (2012). 'De hemel heeft een muis gebaard,' NRC March 30th.

Koeneke, Rodney B. (2004). Empires of the Mind: I. A. Richards and Basic English in China, 1929-1979. Stanford, CA: Stanford University Press.

Körber, H-G (ed.). Aus dem Wissenschaftlichen Briefwechsel Wilhelm Ostwalds, vol. 2.

Berlin: Berlin Akademie Verlag.

Krajewski, Markus (2006). Restlosigkeit: Weltprojekte um 1900. Frankfurt am Main. Fischer

Taschenbuch Verlag.

Krebs', Christopher B. (2011). A Most Dangerous Book: Tacticus's Germania from the

Roman Empire to the Third Reich. New York: W.W. Norton \& Company.

Krebs, Christopher (2009). 'A Dangerous Book: The Reception of the Germania,' in

Woodman, Anthony J., The Cambridge Companion to Tacitus, pp. 280-299. Cambridge:

Cambridge University Press.

Künzli, Andreas (2010). L.L. Zamenhof (1859-1917): Esperanto, Hillelismus (Homaranismus)

und die "jüdische Frage" in Ost und Westeuropa. Wiesbaden: Harrassowitz Verlag.

Lapenna, Ivo \& Lins, Ulrich \& Carlevaro, Tazio (1977). Esperanto en perspektivo: faktoj kaj

analizoj pri la internacia lingvo. London-Rotterdam: UES. p. 424.

Laqua, Daniel (2009). Transnational Endeavors and the Totality of Knowledge: Paul Otlet

and Henri La Fontaine as "Integral Internationalists" Fin-de-Siècle Europe', in Grace

Brockington (ed.), Internationalism and the Arts in Britain and Europe at the Fin de

Siècle, pp. 247-71. Peter Lang: Oxford.

Lewenstein, Bruce (1992).'Public Understanding of Science in the United States after World

War II,' Public Understanding of Science (1): pp. 45-68.

Lins, Ulrich (2008). 'Esperanto as language and idea in China and Japan,' Language

Problems \& Language Planning (32)1: pp. 47-60.

Livingstone, David, N. (2003). Putting Science in its Place: Geographies of Scientific

Knowledge. Chicago: Chicago University Press.

Markham, Jerry W. (2002). A Financial History of the United States. Volume I: From

Christopher Columbus to the Robber Barons (1492-1900). Armonk, NY: M.E. Sharpe, Inc.

Mazower, Mark (2012). Governing the World: The Rise and Fall of an Idea. New York:

Penguin Books Limited.

Mazower, Mark (2012). 'What Remains: On the European Union,' The Nation, September

$5^{\text {th }}$. Retrieved from the Worldwide Web on September $9^{\text {th }}, 2012$ :

http://www.thenation.com/article/169756/what-remains-european-union

Mazower, Mark. (2010). 'Anderson's Amphibologies: On Perry Anderson,' The Nation, April

26th. Retrieved from the Worldwide Web on August 27th, 2012:

http://www.thenation.com/article/andersons-amphibologies-perry-anderson

Mazower, Mark. (2008). No Enchanted Palace: The End of Empire and the Ideological

Origins of the United Nations. Princeton: Princeton University Press. 
Mazower, Mark. (2006). 'An International Civilization? Empire, Internationalism and the Crisis of the Mid-Twentieth Century,' International Affairs (82)3: 553-566.

Matthias, Ulrich (2002). The New Latin for Church and Ecumenism. Translated from

Esperanto by Mike Leon and Maire Mullarney. Antwerp: Flandre Esperanto-Ligo.

McCormmach, Russell (1974). 'On academic Scientists in Wilhelminian Germany,' Deadalus (103)3: pp. 157-171.

McMeekin, Sean (2010). The Berlin-Baghdad Express: The Ottoman Empire and Germany's

Bid for World Power. Cambridge: Harvard University Press.

Mees, Bernard, T. (2008). The Science of the Swastika. Budapest/New York: Central

European University Press.

Megill, Frank R. (1990). The Nobel Prize Winners: 1901-1937. Ipswich, MA: Salem Press.

Meillet, A. (1918). Les Langues dans I'Europe Nouvelle. Paris: Payot \& Cie.

Mellor, Ronald (1999). The Roman Historians. London: Routledge.

Mercer, Christia (2004). Leibniz's Metaphysics: Its Origins and Development. Cambridge:

Cambridge University Press.

Merton, Robert K. (1973) 'The Normative Structure of Science', in Merton, Robert K., The

Sociology of Science: Theoretical and Empirical Investigations, pp. 223-280. Chicago, IL:

University of Chicago Press.

Michels, Eckard (2004). 'Deutsch als Weltsprache? Franz Thierfelder, the Deutsche

Akademie in Munich and the Promotion of the German Langauge Abroad, 1923-1945,'

German History (22)2: pp. 206-228.

Mitchell, Jerry (1999). The American Experiment With Government Corporations. Armonk, NY: M.E. Sharpe.

Murrin, John M. \& McPherson, James M. \& Johnson, Paul E. \& Gerstle, Gary \& Rosenberg,

Emily S. \& Rosenberg, Norman L. (2009). Libery, Equality, Power. Volume II: Since 1863.

Belmont, CA: Clark Baxter.

Nietzsche, Friedrich (1968[1901]). Will to Power. Translated by Walter Kaufmann. New York: Vintage Press.

Nitobe, Inazō (1921). 'Esperanto and the Language Question at the League of Nations,' Report submitted to the Secretary-General of the League of Nations on August $11^{\text {th }}$, 1921. Retrieved from the World Wide Web on March $12^{\text {th }}, 2011$ :

http://www.google.nl/url?sa=t\&rct=j\&q=\&esrc=s\&source=web\&cd=1\&ved=0CCsQFjAA \&url=http\%3A\%2F\%2Fnitobe.info\%2Fld\%2Fdokumentujo\%2Fdokumentoj\%2Fnc_doku mento-18-enkonduko3_en.pdf\&ei=fHmvUJuDLJO2hAe184HgBA\&usg-

=AFQjCNH2ZkWHPglePXOaWX5XqIWJo6R7sg\&sig2=1JCA8MeClemG2-RjGzscfA

Oakes, Leigh (2001). Language and National Identity: Comparing France and Sweden.

Amsterdam: John Benjamins B.V.

Ostwald, Wilhelm (1933). Lebenslinien: Ein Selbstbiographie, band I.

Berlin: Verlag Klasing \& Co.

Ostwald, Wilhelm (1932[1883]). 'Ostwald on Chemical Energy "A Classic Science",' The Science News-Letter, (21)577: pp. 278-280. 
Ostwald, Wilhelm (1916). Letter to Leopold Pfaundler, 12.1.1916. Archiv des

Branderburgischen Wissenschaft Institut, Berlin. Nr. 5277.

Ostwald, Wilhelm. (1915). 'Deutsche Organisation und die Wissenschaft,' Die Umschau

(39), 25th September, pp. 764-766. Archiv der Berlin-Brandenburgischen Akademie der Wissenschaften, nr. 5845/1.

Ostwald, Wilhelm (1915). Weltdeautsch, Monist. Sonntagspredigt von Wilhelm Ostwald. p.

6. Archiv der Berlin-Brandenburgischen Akademie der Wissenschaften, nr. 5282.

Ostwald, Wilhelm (1913). 'Scientific Management for Scientists: "The Bridge." The Trust

Idea Applied to Intellectual Production', Scientific American (108): pp. 5-6.

Ostwald, Wilhelm (1913). 'Internationalismus und Brücke,' Brücken-Zeitung. Zeitschrift für

Organisierung der Geistigen Arbeit (5-6): pp. 1-20. Archiv der Berlin-Brandenburgischen

Akademie der Wissenschaften, nr. 5839.

Ostwald, Wilhelm (1912). 'Der Internationale Organisation der Chemiker,' Annalen der

Natur- und Kulturphilosophie (Zwölfter band), pp. 217-233. Leipzig: Verlag Unsema

G.M.B.H.

Ostwald, Wilhelm. (1911). 'Chemische Weltliteratur,' Die Zeitschrift für Physikalische

Chemie (76): pp. 1-21.

Ostwald, Wilhelm (1910). 'The question of nomenclature,' in Couturat, L. \& Jespersen, O. \& Lorenz, R. \& Ostwald, W. \& Pfaundler. L., International Language and Science:

Considerations on the Introduction of an International Language into Science, pp. 61-

68. London: Constable and Company Limited.

Ostwald, Wilhelm. (1910). Pri La Kemiala Nomizado. Extraktita ek la revue Progresso N 27,

29 e 34 (Mayo, Julio e decembro 1910). Paris: Librarie Ch. Delagrave.

Ostwald, Wilhelm (1907). 'Die internationale hilfsprache,' Reclams Universum (19) February 7th: pp. 438-443.

Ostwald, Wilhelm (1907). 'Der Kulturwert der Hilfsprache,' Allgemeine Zeitung (München), Beilage, (125) July 3rd: pp. 9-12.

Ostwald, Wilhelm (1907). 'Die internationale hiflsprache,' Die Woche, (47) (9-Jahrgang) November 23th: 2047-2048.

Ostwald, Wilhelm (1906). Die internationale Hilfssprache und das Esperanto. Vortag gehalten am 7 November 1906 in der Aula der Handelshochschule zu Berlin. Berlin: Esperanto Verlag Moller \& Borel.

Ostwald, Wilhelm (1905). 'Theorie des Glückes,' Annalen der Naturphilosophie (4): pp. 459474.

Ostwald, Wilhelm (1903). Die Weltsprache. Vortrag gehalten am 4. december $1903 \mathrm{im}$

Bayerischen Bezirksverein des Vereins deutscher Ingenieure. Stuttgart: Frankh'sche Verlagshandlung.

Ostwald, Wilhelm (1895). Die Überwindung des wissenschaftlichen Materialismus. Leipzig: Verlag von Veit \& Comp. 
Otlet, Paul (1990[1914]). 'Union of International Associations: A World Centre,' in Otlet, Paul \& Rayward, Boyd (ed.), International Organization and Dissemination of Knowledge. Selected Essays of Paul Otlet. Translated and Edited with an Introduction by W. Boyd Rayward, pp. 116-129. Amsterdam/New York/Oxford/Tokyo: Elsevier Science Publishing Company Inc.

Perkins, Franklin (2004). 'Leibniz's Exchange with the Jesuits in China,' in Lodge, Paul (ed.), Leibniz and his Correspondents, pp. 141-161. Cambridge: Cambridge University Press.

Poillon, Howard (1935). Howard Poillon to David H. Stevens. December $2^{\text {nd }}, 1935$. Archive of the Research Corporation. Box 7, F. 82.

Ponce de Leon, Charles L. (2002). Self-Exposure: Human-Interest and the Emergence of Celebrity in America, 1890-1940. Chapel Hill, NC: University of North Carolina Press. Pyenson, Lewis \& Verbruggen, Christophe (2009) 'Ego and the International: The Modernist Circle of George Sarton,' Isis (100): pp. 60-70.

Rasmussen, Anne. (2012) 'Science and Technology,' in: Horne, John (ed.), A Companion to World War I, pp. 307-323. Malden, MA: Blackwell Publishing.

Rasmussen, Anne (2004). 'La science française dans la guerre des manifestes, 1914-1918,' Mots. Les langages du politique (76): pp. 9-23.

Rasmussen, Anne (1996). 'À la recherche d'une langue internationale de la science,' in Chartier, Rogier \& Corsi, Pietro (eds.), Sciences et Langues en Europe, pp. 139-155. Paris: École des Études en Sciences Sociales.

Randeraad, Nico (2010). States and Statistics in the Nineteenth Century: Europe by Numbers. Manchester: Manchester University Press.

Rayward, W. Boyd (1994). 'Visions of Xanadu: Paul Otlet (1868-1944) and hypertext,' Journal of the American Society for Information Science (45): pp. 235-50.

Rayward, Boyd (1975). The Universe of Information: the Work of Paul Otlet for

Documentation and International Organization. FID Publication 520. Moscow: Published for the International Federation for Documentation by the All-Union Institute for Scientific and Technical Information (Viniti).

Reinbothe, Roswitha (2010). 'L'exclusion des scientifiques allemands et de la langue allemande des congrès scientifiques internationaux après la Première Guerre mondiale,' Revue Germanique Internationale (12): pp. 193-208.

Reinbothe, Roswitha (2006). Deutsch als internationale Wissenschaftssprache und der Boykott nach dem Ersten Weltkrieg. Frankfurt am Main: Verlag Peter Lang.

Rescher, Nicholas (2002). Enlightening Journey. The Autobiography of an American Scholar. Lanham, Maryland (US): Lexington Books.

Rice Pierce, Ann (2007). Woodrow Wilson \& Harry Truman: Mission and Power in American Foreign Policy. New Brunswick, NJ: Transaction Publishers.

Rife, Patricia (2007). Lise Meitner and the Dawn of the Nuclear Age. Boston: Birkhäuser. Rivarol, Antoine (1797). De I'Universalité de la langue Française. Paris: Chez Cocheris, Imprimeur-Libraries. 
Rodnyj, Naum I. \& and Solowjew, Jurij I. (1977). Wilhelm Ostwald:

Biographien Hervorragender Naturwissenschaftler, Techniker und Mediziner. Leipzig:

Teubner Verlag.

Rogers, Donald, W. (2009). Making Capitalism Safe: Work Safety and Health

Regulation in America, 1880-1940. Urbana, IL: University of Illinois Press.

Rozwadowski, Helen M. (2002). The Sea Knows No Boundaries: A Century of Marine

Sciences Under Ices. Washington: University of Washington Press.

Rosenberg, Emily (ed.) (2012). 'A World Connecting: 1870-1945, vol. 5,' of Iriye, Akira \&

Osterhammel, Jürgen (gen. eds.), A History of the World (6 vols.). Cambridge, Mass:

Harvard University Press.

Rosenberg, Emily (2012). 'Introduction,' in A World Connecting: 1870-1945, vol. 5 of Iriye,

Akira \& Osterhammel, Jürgen (gen. eds.) \& Rosenberg, Emily (ed.), A History of the

World (6 vols), pp. 3-25. Cambridge, Mass: Harvard University Press.

Russell, Bertrand (2005[1957]). 'The Importance of Shelley,' in Russell, Bertrand \& Bone,

Andrew G. (ed.), Collected Papers of Bertrand Russell. Volume 29: Détente or

Destruction, 1955-57, pp. 75-78. London/New York: Routledge.

Russell, Bertrand (1998[1951-1961, 3 vols.]). The Autobiography of Bertrand Russell.

London/New York: Routledge.

Sachsse, Rolf (2004). 'Das Gehirn der Welt: 1912,' in Weibel, Peter (ed.), Wilhelm Ostwald:

Farbsysteme - Das Gehirn der Welt, pp. 64-88. Ostfildern: Hatje Cantz Verlag.

Sapir, Edward (1929). 'The Status of Linguistics as a Science,' Language (5)4: pp. 207-214.

Sarton, George (1988[1937]). The History of Science and the New Humanism. With

Recollections and Reflections by Robert K. Merton. Brunswick, NJ: Transaction Inc.

Sarton, George (1923). 'Knowledge and Charity,' Isis (5)1: pp. 5-19.

Sarton, George (1919). 'War and Civilization,' Isis (2)2: pp. 315-321.

Schmid, Anne-Françoise (ed.), Bertrand Russell Correspondence sur la Philosophie, la

Logique et la Politique avec Louis Couturat. Paris: Éditions Kimé.

Schmitz, Walter H. (1985). 'Andre Lalande and the Terminology Critical Movement in

France,' in Welby, Lady Victoria \& Schmitz, Walter H. (ed.), Significs and Language: The

Articulate Form of Our Expressive and Interpretive Sources, pp. cxi-cxviii. Amsterdam:

John Benjamins Publishing.

Schroeder-Gudehus, Brigitte (1990). 'Les congrès scientififiques et la politique de coopération internationale des académies de sciences,' Relations Internationales (62): pp. 135-48.

Schroeder-Gudehus, Brigitte (1978). Les Scientifiques et la Paix. La Communauté

Scientifique Internationale au Cours des Années 20. Montréal: Les Presses de I'Université de Montréal.

Schroeder-Gudehus, Brigitte (1975). 'Challenge to Transnational Loyalties: international scientific organizations after the First World War,' Science Studies (3): pp. 93-118. 
Semper, Gottfried (1966[1852]). 'Wissenschaft, Industrie und Kunst', in Wingler, Hans M.

(ed.), Wissenschaft, Industrie und Kunst, und andere Schriften über Architektur,

Kunsthandwerk und Kunstunterricht. Mainz/Berlin: Kupferberg.

Servos, John (1999). Physical Chemistry from Ostwald to Pauling: The Making of a Science

in America. Princeton: Princeton University Press.

Shapin, Steven (2008). The Scientific Life: A Moral History of a Later Modern Vocation.

Chicago: University of Chicago Press.

Shapin, Steven (2007). 'Science and the Modern World,' in The Handbook of Science and

Technology Studies, 3rd Ed., Hackett, Edward \& Amsterdamska, Olga \& Lynch, Michael

\& Wajcman, Judy (eds.), pp. 433-448. Cambridge, MA: MIT Press.

Shinn, Terry \& Crawford, Elisabeth \& Sörlin, Sverker (1992). 'The Nationalization and

Denationalization of Science. An Introductory Essay,' in Shinn, T. \& Crawford, E. \&

Sörlin, S. (eds.), Denationalizing Science: The Contexts of International Scientific

Practice, pp. 1-43. London etc.: Kluwer Academic Publishers.

Skibell, Joseph. 'Stephen F. Foster, Historical Truth \& Novel.' Retrieved from the World

Wide Web October $1^{\text {st }}, 2012$ : http://www.wondersandmarvels.com/2010/08/stephen-

f-foster-historical-truth-the-novel.html

Smith, Woodruff D. (1991). Politics and the Sciences in Germany, 1840-1920. New

York/Oxford: Oxford University Press.

Sobczyriska, Danuta. Czerwiriska, Ewa (1998). 'Szientismus in der Praxis. Das Wirken

Wilhelm Ostwalds im Deutschen Monistenbund,' Philosophisches Jahrbuch (105)1: pp.

178-194.

Somsen, Geert (2013). 'Wetenschap als Werelderfgoed. George Sartons

Internationalistische Geschiedschrijving,' in Huisman, Frank \& Randeraad, Nico \& Georgi

Verbeeck (eds.), Geschiedenis is Overal, pp. 104-121. Amsterdam: Wereldbibliotheek.

Somsen, Geert. (2008). 'A History of Universalism: Conceptions of the Internationality of

Science from the Enlightenment to the Cold War,' Minerva (46)3: pp. 361-379.

Sondhaus, Lawrence (2011). World War One: The Global Revolution. Cambridge:

Cambridge University Press.

Soulié, Stephan (2009). Les Philosophes en République: L'aventure Intellectuelle de la

Revue Métaphysique et de la Morale et de la Société Française de Philosophie (1819-

19140). Rennes: Presses Universitaires de Rennes.

Speeckaert, Georges Patrick (1957). The 1,978 Organisations Founded Since the Congress of

Vienna: Chronological List. Brussels: Union of International Organisations.

Surman, Jan (2012). 'Science and its publics: Internationality and National Languages in

Central Europe,' in Ash, Mitchell G. \& Surman, Jan (eds.), The Nationalization of

Scientific Knowledgein the Habsburg Empire, 1848-1918. pp. 30-56. New York: Pallgrave Macmillan.

Sutton, Geoffrey H. (2008). Concise Encyclopedia of the Orginal Literature of Esperanto:

1887-2007. New York: Mondial Publishing. 
Tenkotte, Paul A. (1987). 'Kaleidoscopes of the World: International Exhibitions and the Concept of Culture-Place, 1851-1915,' American Studies (28)1: pp. 5-29.

Thomas D. (2004). Establishing Research Corporation. A Case Study of Patents, Philanthropy, and Organized Research in Early 20th Century America. Tucson, Arizona: Research Corporation.

Thomas, Linda \& Wareing, Sha N. (2005). Language Society and Power: An Introduction. New York: Routledge. Bert Theunissen, 'Unifying science and human culture: the promotion of the history of science by George Sarton and Frans Verdoorn,' in Somsen, Geert \& Kamminga, Harmke (eds.), Pursuing the Unity of Science: Ideology and Scientific Practice Between the Great War and the Cold War (Aldershot: Ashgate Publishing, forthcoming).

Traweek, Sharon (1992). Beamtimes and Lifetimes: The World of High Energy Physicists.

Cambridge: Harvard University Press.

Uekötter, Frank (2009). The Age of Smoke: Environmental Policy in Germany and the United States. Pittsburg: Pittsburg University Press.

Urquhart, Alasdair (2002). 'The Couturat-Russell Correspondence [review of A.-F. Schmid (ed.), Bertrand Russell Correspondance sur la Philosophie, la Logique et la Politique avec Louis Couturat (1897-1913)],' Russell: the Journal of Bertrand Russell Studies (22)2: pp. 188-192.

Vincent Lee McKusick, Vincent, L. (1948). 'A Study of Patent Policies in Educational Institutions, Giving Specific Attention to the Massachusetts Institute of Technology,' Journal of the Franklin Institute (245)4: pp. 193-270.

Walcher, Thomas (2000). 'The Internationalism of Science as an Ideal', The CERN Courier. Retrieved from the Worldwide Web on September $12^{\text {th }}, 2009$ : http://cerncourier.com/cws/article/cern/28359

Walden, Paul (1904). Wilhelm Ostwald. Leipzig: Verlag von Wilhelm Engelmann. Washburn, Jennifer (2006). University Inc.: The Corporate Corruption of Higher Education. New York: Basic Books.

Wattenberg, Dieter (ed.) (1977). Wilhelm Foerster in seinen Tagebuchblattern über die Meter-Konferenzen in Paris. Wiesbaden: Franz Steiner Verlag.

Waquet, Françoise. (2001). Latin or the Empire of a Sign: From the Sixteenth to the Twentieth Centuries. London/New York: Verso.

Weber, Max (1984[1909]). 'Energetic' Theories of Culture,' translated by Mikkelson, Jon M. \& Schwartz, Charles, Mid-American Review of Sociology (9)2: pp. 33-58.

Weinberg, Steven. (2007). Nobel Laureate Disses NASA's Manned Spaceflight. By Ker Than. Retrieved from the Worldwide Web on August 30th, 2012: http://www.space.com/4357-nobel-laureate-disses-nasa-manned-spaceflight.html Weindling, Paul (1997). 'Philanthropy and World Health: The Rockefeller Foundation and the League of Nations Health Organisation,' Minerva (35): pp. 269-281.

Wiggins, D. (2006). Ethics: Twelve Lectures on the Philosophy of Morality. Cambridge: Harvard University Press. 
Wolff, Stefan L. (2003). 'Physicists in the "Krieg der Geister": Wilhelm Wien's

"Proclamation",' Historical Studies in the Physical and Biological Sciences (33)2: pp. 337386.

Kim, Young, S. (1999). 'Constructing a Global Identity,' in Boli, John \& Thomas, George, M. (eds.), Constructing World Culture: International Non-governmental organizations since 1875, pp. 117-148. Stanford, California: Stanford University Press.

(1900). 'The International Association of Scientific Societies', Science (11)365: pp. 124-125. (1902). Compte rendue du Deuxième Congrès Internationale des Mathématiciens. Tenu à

Paris du 6 au 12 aout 1900. Paris: Gauthier-Villars, Imprimeur-Librairie.

(1911). Kölnische Volkszeitung (51)106, Februari $5^{\text {th }}$ : pp. 1-2.

(1889). 'International language (Editorial),' Science 13 (310): pp. 24-25.

(1914). 'Manifesto of the Ninety-Three German Intellectuals', WW I Document Archive:

1914 Documents. Retrieved from the World Wide Web on October $2^{\text {nd }}, 2012$ :

http://wwi.lib.byu.edu/index.php/Manifesto_of_the_Ninety-

Three_German_Intellectuals

(1915). Information for the Visitors to the Panama-Pacific International Exposition. San Francisco, 1915. Retrieved from the Worldwide Web on January $8^{\text {th }}, 2012$ :

http://www.books-aboutcalifornia.com/Pages/Info_for_Visitors_PPIE/Info_for_Visitor_PPIE_text.html

(1919). Treaty of Versailles. Signed at Versailles, June $28^{\text {th }} 1919$. Retrieved from the Wordwide Web on October $17^{\text {th }}, 2012$ :

http://avalon.law.yale.edu/subject_menus/versailles_menu.asp

(1920). Fifth Annual Report of the National Research Council. Washington: Government Printing Office.

(1921). 'News: University and Educational Intelligence,' Nature (108)2716: p. 386.

(1933). International Auxiliary Association in the United States, Inc. A Report to the Research Corporation. RC archives. Box 42, F 527.

(1943). 'Richards of Harvard Creates Basic English. System Mentioned in Churchill Talk,' The Harvard Crimson. September, 10th. Retrieved from the Worldwide Web on January $10^{\text {th }}, 2012$ : http://www.thecrimson.com/article/1943/9/10/richards-of-harvard-createsbasic-english/

(1948). 'The Talk of the Town,' The New Yorker, September 25th (24): p. 24. 'Introduction,' NASA - International Space Station. Retrieved from the Worldwide Web on August $30^{\text {th }}$, 2012: http://www.nasa.gov/mission_pages/station/main/index.html

'How much does it cost?' ESA Human Spaceflight and Exploration -International Space Station. Retrieved from the Worldwide Web on August $30^{\text {th }}, 2012$ :

http://www.esa.int/esaHS/ESAQHAOVMOC_iss_0.html

'Interactive Timeline,' Research Corporation for Science Advancement. Retrieved from the Worldwide Web on January $5^{\text {th }}$, 2013: http://www.rescorp.org/aboutrcsa/history/timeline. 

INDEX

Académie Française, 150

Action Française, 59

Africa, 63, 64, 99, 144

American Association for the Advancement of

Science, 114

American Chemical Society, 80, 106, 126

American Philosophical Society, 53

Amerika Esperantista Asocio, 113

Anatolian Railway, 100

Appell, Paul, 59

Arnold Sommerfeld, Arnold, 92

Asia, 64, 99

Atomism, 91, 92

Bacon, Francis, 70

Basic English, 110, 111

Belgium, 160

Bell, Alexander Graham, 116

Beaufront, Louis de, 44, 76, 107

Bergson, Henri, 39, 59

Berlin-Bagdad railway, 100

Billot, Baptiste, 59

Boirac, Emile, 77

Boutroux, Emile, 38

Boyle, Robert, 25

British Association for the Advancement of Science, 129

Brücke, 76-82, 84, 98, 99, 100, 143

Brunetière, Ferdinand, 60

Bührer, Karl Wilhelm, 79, 84

Bureau de Longitude, 74

Bureau international des poids et mesures, 51

Bureau of Mines, 106, 114, 115, 119, 127, 129

Calculus ratiocinator, 58, 59

Cantor, Moritz, 39

Carnegie Corporation, 122

Carnegie, Andrew, 122, 130, 131, 132

Cavaignac, Godefroy, 59

CERN, 19

Characteristica universalis, 57-59, 61, 63, 142, 159

China, 18, 63, 100, 109, 111, 143, 146, 159

Collège de France, 45

Collinson, Edward, 133

Columbia University, 132
Comité international des poids et mesures, 51

Committee on Intellectual Cooperation (of the League of Nations), 18

Comte, Auguste, 69

Concert of Europe, 27

Conflict Thesis, 19

Cornell Association in Civil Engineers, 123

Cornell University, 20

Cottrell, Frederick Gardner, 7, 26, 104-107, 111-129,

132, 133, 134, 140, 142, 143, 144, 147

Council of Foreign Relations, 131

Couturat, Louis, 6, 26, 36-47, 49-51, 53-62, 64-67, $69-77,81,83,89,99,105,107,117,135,138$,

140-144, 147, 155, 159

Crystal Palace, 51

Dalgarno, George, 42, 58

Darboux, Gaston, 42, 51, 59

Darrow, Karl K., 19

Darwin, Charles, 94

Davis, Watson, 136

de Beer, Gavin, 20, 21, 24, 138

de Rivarol, Antoine, 65, 151

Delauney, Eugène, 52

Descartes, Rene, 42, 70

Die Krieg der Geister, 100

Diels, Hermann Alexander, 53

Dorpat, 69, 86, 89

Dreyfus affair, 59, 65

Dreyfus, Albert, 59

Einheitsformat. See Die Brücke

Einstein, Albert, 18, 22

Electrostatic precipitator, 105

energetics, 6, 67, 69, 85, 90-93, 142

Esperantista Asocio de Norda Ameriko, 113

Esperanto, 15-17, 26, 31, 32, 37-40, 42-45, 47, 58, $67,71,75-77,86,104,105,109,110,112-114$,

131, 134-136, 141, 144, 146

Espero Katolika, 16

Ethiopia, 18

Far East, 64, 144

Fichte, Johann Gottlieb, 153, 154, 155

First International Congress of Philosophy (1900), 38 
Foerster, Wilhelm, 52, 74

Folk psychology, 95

Fontainebleau, 50

Formel Sprache, 56

Frege, Gottlob, 56

French Academy of Sciences, 42

Galilei, Galileo, 19

Gantt, Henry, 124

German Monistic Alliance, 85, 100

Goddard, Robert H., 105

Gode, Alexander, 133, 134, 135, 136

Grabowski, Antoni, 17

Grégoire, Henri, 151

Haber, Frits, 87

Habsburg Monarchy, 23

Haeckel, Ernst, 85, 100

Hale, George Ellery, 22, 126, 127

Hammond, John Henry, 132

Harvard University, 9, 31, 62, 75, 89, 100, 110, 111,

$131,148,163,168,171,173,174$

Havet, Louis, 53

Haydarpaşa Terminus, 100

Helm, Georg, 91

Henderson, George J., 53

Hennen Morris, David, 105, 129, 132

Herder, Johann Gottfried, 153

Hillelism. See Zamenhof, Ludovic Lasarus

Holmes, Joseph H., 119

Hübner, Paul, 16

Humboldt, Wilhelm von, 153, 154

Ido, 6, 26, 31, 32, 36, 37, 40, 44, 45-47, 49, 50, 53,

$55,56,58-61,64-67,69,76-86,89,90,93,98-100$,

$103,105,107-110,113,114,134-136,138,140-$

144, 146, 147, 151, 155, 156,

Inazō, Nitobe, 109, 110, 166

Interlingua, 7, 107, 133, 134, 135, 136

Interlingua Institute, 136

International Association of Academies, 42

International Catalogue of Scientific Literature, 51

International Committee on Intellectual Cooperation

(later UNESCO), 109

International Conference on Geodesy in 1867, 52

International Congress of Arts and Science (St. Louis),

88

International Office of Bibliography, 29

International Space Station (ISS), 12
Istanbul, 100

Jespersen, Otto, 109

Kant, Emmanuel, 60, 92

Kiautschou, 100

Kulturträger, 93

Lafontaine, Henri, 28, 29, 30, 31, 155

Lalande, André, 54

Lamprecht, Karl, 68, 94, 95, 100

Latin, 16, 32, 38, 43, 45, 53, 55, 71, 74, 86, 97, 98,

$102,113,141,143,144,147,152,156$,

Lawrence, Ernest, 105

le Challas, George, 39

League of Nations, 18, 109, 110, 112, 131, 143

Leau, Leopold, 41, 42, 43, 75, 81

Leau, Léopold, 41

Leibniz Nachlass, 57

Leibniz, Gottfried Wilhelm, 36, 38-40, 42, 44, 56-59,

61-64, 70, 142, 144, 159

Leipzig, 66, 67, 68, 87, 88, 92, 94, 98, 104

Leipzig Circle, 94

Léon, Xavier, 39, 41, 54

Leroy-Beaulieu, Paul, 53

Loeb, Jaques, 88

London World's fair, 88

Manifesto of Ninety-Three, 100

Maurras, Charles, 59

Meillet, Antoine, 150

Mein Kampf, 110

Merton, Robert, 101

Metre Convention of 1875, 51

Middle East, 64, 144, 146

Military chauvinism, 60

Moch, Gaston, 76

Mommsen, Theodor, 54

Monism, 85

Monistic Alliance, 6, 77, 85, 86

Morris, John Albert, 131

Mudaneum, 29

Munich, 78, 84, 110

NASA, 19

National Research Council, 106, 126, 127, 129, 174

New Machine, 124

New York, 132

Newspeak, 111 
Oettingen, Arthur von, 69

Ogden, C.K., 110

Oppenheimer, Robert, 18

Orwell, George, 111

Ostwald, Wilhelm, 6, 26, 66-105, 107, 110, 111, 117, $125,138,140-144,147,155$

Otlet, Paul, 28, 29, 30, 31, 146, 155

Ottoman Empire, 100

Pact of Locarno, 21

Painlevé, Paul, 59

Panama Canal, 116

Paris, 21, 26, 36, 37, 38, 40-42, 45, 46, 50, 52, 53, 55,

57, 58-60, 61, 65, 74-76, 83, 88, 94, 102, 150, 152

Paris Academy of Science, 74

Paris Metre Conference, 74

Paris World's Fair, 88

Peano, Giuseppe, 56

Peirce, Charles Sanders, 56

Peltier, Emile, 16

Physical chemistry, 66, 70, 75, 87, 88, 89, 104, 155

Picard, Émile, 36

Piéron, Henri, 22

Planck, Max, 91, 92, 100

Poillon, Howard, 132

Poincaré, Henri, 39, 59

Progreso, 47, 83

Progressivism, 117, 121

Prou, Maurice, 53

Prout, Gaslee, 123

Reseach Corporation, 105, 106, 114, 118, 119, 120 -

123, 132, 133

Renan, Ernest 158

Republic of Letters, 13, 51, 62, 97, 98, 156, 159,

Richards, Ira, 110

Riga, 86, 87, 89

Ritter, William Emerson, 135

Rockefeller Foundation, 111, 131, 173

Rockefeller, John D., 111, 122, 130, 131, 132, 133

Roman Empire, 150, 153, 154, 156, 158

Roosevelt, Theodore, 121

Russell, Bertrand, 36, 39, 40, 55-57, 60, 138, 145

Saager, Adolf, 78

San Francisco World's fair, 115

Sapir, Edward, 134

Sarton, George, 31, 145, 146

Schleyer, Martin, 38, 69, 70
Schmitt, Carl, 87

Schneeberger, Friedrich, 77

Science Service, 135

Scripps, Edward W., 135

Second International Mathematical Congress, 41, 55

Semper, Gottfried, 50

Shenton, Herbert, 132

Skibell, Joseph, 36

Smithsonian Institution, 115, 119

Société Pour la Propagation de l'Espéranto, 44

Spencer, Herbert, 94

Standard Average European (SAE), 135

Stevens, David H., 133

Stillman, Ezra Clark, 133, 134

Strong Program, 25

Structural objectivity, 56, 58, 142, 143

Suess, Eduard, 54

Switzerland, 77, 85, 127, 138, 160

Tacitus, Publius Cornelius, 154, 158

Tannery, Jules, 36, 59

Thermodynamics, 67, 69, 70, 90

Thierfelder, Franz, 110

Tobler, Theodor, 77, 78

Toblerone, 77, 78

Toulouse, 39

Transnational history, 33

Treaty of Versailles, 126

United Nations, 18

Universal Decimal Classification, 28

Vanderbilt Morris, Alice, 105, 129

Vanderbilt, Alice Morris, 107, 130, 131, 132, 135

Vanderbilt, William Henry, 129

Van 't Hoff, Jacobus Henricus, 81-83, 87, 88, 90, 104, 138

Veblen, Thorstein, 123, 124, 142

Versammlung Deutscher Naturforscher und Ärzte, 91 Volapük, 38, 40, 42, 53, 69, 104, 141

Walcott, 114, 115, 119

Weber, Max, 39, 68

Weinberg, Steven, 12

Wells, H.G., 111

Weltdeutsch, 69, 103, 107, 110, 140, 144

Weltformat, 79

White, Andrew Dickson, 19

Whitehead, Alfred, 20 
Whorf, Benjamin Lee, 134, 135

Wilhelm II, 69, 99, 126

Wilkins, John, 58

Wilson, Woodrow, 107, 109, 121, 125, 126

World Fair in St. Louis, 88

World War I, 6, 22, 27, 50, 69, 100-102, 107, 113,

$117,125,131,140,143$
World War II, 13, 18, 110, 111, 135, 159

Wundt, Wilhelm, 94, 95, 100

Young Women's Christian Association, 130, 131

Zamenhof, Ludovic Lasarus, 16 


\section{SAMENVATTING}

Deze studie zoomt in op een opmerkelijke episode in de geschiedenis van de wetenschap, namelijk vroeg twintigste-eeuwse pogingen van wetenschappers om een internationale taal voor en door de wetenschap te creëren. De centrale figuren in deze episode waren de Franse mathematicus en logicus Louis Couturat (1868-1914), de Duitse scheikundige en Nobel laureaat Wilhelm Ostwald (1877-1948) en de Amerikaanse scheikundige en uitvinder Frederick G. Cottrell (1877-1948). Deze pogingen waren geïnspireerd door andere internationale taalbewegingen in de periode, in het bijzonder de Esperanto-beweging. Wat hun internationale taalproject anders maakte was dat zij wetenschappelijke methoden toepasten om een taal te creëren die als soepele, neutrale en vooral efficiënte drager voor wetenschappelijke kennis op internationale congressen en in publicaties moest functioneren. Deze nieuwe taal diende dan ook gezien te worden als een moderne versie van het Latijn, de drager van kennis tijdens de legendarische République des Lettres.

Alhoewel de schepping en implementatie van een wetenschappelijke taal het beeld van wetenschappers als voorbeeldige internationalisten lijkt te bevestigen, toont deze studie aan dat de interventies van Couturat, Ostwald en Cottrell vooral uitdrukkingen waren van persoonlijke en nationale agenda's. Als zodanig dienden hun campagnes voor een internationale wetenschappelijke taal de belangen van specifieke professionele, regionale en nationale groepen. Sterker nog, de nieuwe taal waarvoor zij in de bres sprongen faciliteerde een wereldorde die de hegemoniale en imperiale agenda van de thuisnatie weerspiegelde. Er bestond echter nog een parallel tussen de agenda's van de drie internationalisten enerzijds en die van nationalisten anderzijds. Door een internationale taal te promoten kopieerden zij van de nationalisten namelijk het gebruik van taal als middel om een gemeenschap te construeren. Alleen deden zij dit op internationaal niveau. 


\section{Hoofdstuk 1}

De eerste paragraaf focust op het ideaal van wetenschappelijk internationalisme en internationalisme als politieke stroming in bredere zin. Het laat zien dat er binnen de geschiedschrijving relatief weinig aandacht is voor deze beweging en als er wel over wordt geschreven heeft men de neiging om de agenda van internationalisten te idealiseren. Internationalisme wordt namelijk veelal als de positieve wederhelft van nationalisme geportretteerd. Hierbij wordt het beschreven als een politiek programma dat min of meer losstaat van persoonlijke en nationale belangen. De drijfveer voor interventies van internationalisten zou vooral op een globaal niveau liggen om de economische en politieke samenwerking in het voordeel van iedereen te bevoorderen. Voorts gaat men ervan uit dat deze agenda min of meer onveranderd is gebleven sinds de opkomst van internationalisme in de negentiende eeuw.

Recent onderzoek laat echter zien dat internationalisme sinds haar geboorte vele ideologische varianten kent. Belangrijker nog: de agenda van internationalisten wordt gedreven door uiteenlopende belangen en concepties van wereldorde die bovenal voordelen opleveren voor bepaalde regionale, nationale, professionele en geloofsgemeenschappen. Deze divergentie aan belangen heerst niet alleen tussen verschillende bewegingen die een internationalistische agenda nastreven; deze is ook van toepassing binnen gemeenschappen waarvan de leden op het eerste gezicht dezelfde internationalistische agenda lijken te delen. Dit punt wordt geïllustreerd door nader in te gaan op de Esperanto beweging.

Paragraaf 1.1 laat zien dat alhoewel het enge karakter van de internationalistische agenda's van politici langzamerhand wordt blootgelegd, dit nog niet wordt gedaan voor wetenschappers. Sterker nog, wetenschappers worden over het algemeen als voorbeeldige internationalisten neergezet. Dit punt wordt verder geïllustreerd aan de hand van verschillende historische en eigentijdse voorbeelden. Vervolgens wordt aangetoond dat dit beeld sinds de jaren zestig veelvuldig is ontkracht door wetenschapshistorici. Het merendeel van de studies die worden besproken beschrijven wetenschappers die zich tijdens oorlogen niet anders gedroegen dan politici en ordinaire burgers. Wetenschappers weigerden om met collega's van de tegenpartij samen te werken, namen actief deel aan propaganda campagnes en pleitten voor de relevantie van hun vak voor oorlogsvoering. Tevens worden studies opgevoerd die aantonen dat wetenschap in tijden van vrede door nationale belangen werd gedreven. Een groot aantal geallieerde wetenschappers weigerden tot aan het begin van de jaren dertig om met Duitse wetenschappers samen te werken. En zelfs de selectie van Nobelkandidaten werd ingezet om nationale belangen te bevorderen.

Paragraaf 1.2 laat echter zien dat alhoewel het beeld van wetenschappers als voorbeeldige internationalisten veelvuldig is ontkracht, er nog altijd een beeld van wetenschap wordt gepresenteerd als bestaande uit een harde kern met een zachte buitenkant. Het idee is dat de zachte buitenkant soms gecorrumpeerd kan raken door 
externe belangen, maar de harde kern is ondoordringbaar. Deze harde kern bevat de sleutelkenmerken van wetenschap, waaronder het universele karakter van wetenschappelijk kennis en de neiging van wetenschappers om samen te werken. Deze waarden zouden onveranderlijk en tijdloos zijn.

Vervolgens wordt aangetoond dat dit beeld belangrijk onderzoek van een groep sociologen en historici negeert wiens werk in de traditie van het Strong Program staat. Voor hen is het een basisaanname dat wetenschappelijke kennis en praktijken lokaal en cultureel ingebed zijn. Dit punt wordt verder uitgewerkt aan de hand van twee canonieke studies die binnen deze school zijn verschenen.

De eerste twee alinea's van paragraaf 1.3 maken duidelijk dat alhoewel de voorliggende studie in de traditie van de Strong Program staat, het centrale studieobject niet de politiek van de praktijk van kennisproductie is. Ook is het niet de bedoeling om het beeld van wetenschappers als voorbeeldige internationalisten te ontkrachten. Het hoofdobject van deze studie is namelijk het gebruik van de mythe van wetenschappers als voorbeeldige internationalisten, oftewel de levensloop en functies van de ideologie van wetenschappelijk internationalisme. Om deze ideologie te begrijpen moeten we haar in de historische context plaatsten waarin deze wordt gearticuleerd. Daarom zoomt dit boek in op een vroeg twintigste-eeuws geval van internationalisme, namelijk pogingen van wetenschappers om een internationale taal voor en door de wetenschap te creëren.

De volgende alinea's introduceren de drie hoofdpersonen: de Franse wiskundige en logicus Louis Couturat (1868-1914), de Duitse chemicus en Nobel laureaat Wilhelm Ostwald (1853-1932) en de Amerikaanse chemicus en uitvinder Frederick Cottrell (1877-1948). De drie protagonisten beweerden dat er in toenemende mate communicatie problemen waren op internationale congressen en in wetenschappelijke publicaties. De oorzaak van dit probleem was een plotselinge toename van nationale talen binnen de wetenschappelijke gemeenschap. De adoptie van een wetenschappelijk geconstrueerde taal was in hun ogen de enige oplossing. Het beoogde resultaat was een gerationaliseerde en gestroomlijnde taal die volledig bevrijd was van onnodig complexe grammaticale structuren en vrijwel geen nationale elementen bevatte die gebruikers bevoor- of benadeelde. Het was ook de bedoeling dat het een centrale taal voor de gehele internationale gemeenschap werd en als zodanig bijdroeg aan het ontstaan van een rationeel georganiseerde en vredige wereldorde.

De volgende reeks alinea's laat zien dat een dergelijk 'wetenschap als eenheidsmachine' programma niet uniek was aan het begin van de twintigste eeuw. Dit wordt geïllustreerd aan de hand van één van de bekendste initiatieven in die periode, namelijk de creatie en toepassing van een universeel classificatiesysteem door de Belgische bibliografen Paul Otlet (1868-1944) en Henri Lafontaine (1854-1943). Ook zij claimden hiermee de toegankelijkheid van kennis te vergemakkelijken ter bevordering van de unificatie van de internationale gemeenschap. De Britse historicus Mark Mazower presenteert hun initiatief zelfs als een typisch voorbeeld van de 'wetenschap als eenheidsmachine' beweging. 
Vervolgens wordt beargumenteerd dat de ogenschijnlijke gelijkenis tussen beide 'wetenschap als eenheidsmachine' projecten slechts oppervlakkig was. Niet alleen bestonden er belangrijke instrumentele verschillen tussen deze projecten. Otlet en Lafontaine richtten zich immers op bibliografie, niet op taal. Op een dieper niveau werden de initiators van deze projecten door verschillende ideologische agenda's gedreven. Het doel van de voorliggende studie is om aan te tonen deze ideologische diversiteit zelfs binnen een specifiek internationalistisch project heerste. Om dit aan te tonen worden de ideologische programma's van haar drie protagonisten in kaart gebracht.

De twee alinea's van paragraaf 1.4 wijzen erop dat er vrijwel geen historisch onderzoek is verricht naar de promotie van een wetenschappelijke taal door Couturat, Ostwald en Cottrell. De enige studie die serieus ingaat op de pogingen van Couturat (Ostwald wordt kort genoemd, Cottrell ontbreekt) verklaart deze als gedreven door het verlangen om een oplossing te bieden voor de toenemende taaldiversiteit. Hiermee wordt echter de situatie urgenter voorgesteld dan het geval was. Roswitha Reinbothe toont aan dat destijds weinig wetenschappers de toen heersende taaldiversiteit als een obstakel ervoeren. Het lijkt er dus op dat de drie protagonisten niet zo zeer door een bredere vraag naar een wetenschappelijke internationale taal werden gedreven maar door een eigen agenda.

De volgende vier alinea's gaan in op de methode waarop de verschillende ideologische agenda's van de drie protagonisten in kaart word gebracht. Eén van de centrale parameters die bij dit proces in acht wordt genomen wordt ingegeven door de Transnational History benadering. Het wordt duidelijk gemaakt dat alhoewel de natie uiteindelijk een centrale rol speelt in het duiden van de politieke agenda's van drie protagonisten, hun ervaringen, interacties en motieven ook voorbij en onder het niveau van de natie worden getraceerd.

De laatste alinea's bieden een programmatisch overzicht van deze studie. Hierbij krijgt hoofdstuk 5 een aparte rol toebedeeld. Hoofstukken 2, 3 en 4 zijn ieder afzonderlijk aan de drie protagonisten gewijd. Deze hebben het gedeelde doel om hun ideologische agenda's in kaart te brengen. Hoofdstuk 5 heeft echter een andere insteek. Het eerste deel biedt een uitgebreide vergelijking en analyse van de drie agenda's. Het tweede analyseert de internationale taalpolitiek van de drie protagonisten als een strategie van gemeenschapsconstructie zoals dat inmiddels een standaardbenadering binnen studies van het nationalisme is.

\section{Hoofdstuk 2}

Paragraaf 1.1 introduceert Louis Couturat en zijn eerste schreden tot promotie van een internationale taal voor en door de wetenschap. Hierbij wordt aangetoond dat hij tijdens het eerste internationale congres voor filosofie in Parijs in 1900 de taak op zich nam om het 
onderwerp van internationale talen nader onder de loep te nemen. Tijdens de daarop volgende jaren ontwikkelde deze taak zich tot een roeping. Dit blijkt onder andere uit zijn correspondentie met de Britse filosoof en logicus Bertrand Russell, waaruit blijkt dat hij reeds in 1901 overtuigd raakte van de noodzaak voor een internationale taal. In datzelfde jaar richtte Couturat samen met de mathematicus Leopold L'eau de "Delegatie voor de Adoptie van een Internationale Taal" op.

Paragraaf 2.2 gaat dieper in op Couturat's argumenten voor de noodzaak van een internationale taal door zijn monumentale studie Histoire de la Langue Universelle (1903) nader te bestuderen. Hierin blijkt dat hij de internationale wetenschappelijke gemeenschap associeerde met de toren van Babel. Spraakverwarring en een gebrekkige transfer van kennis wegens taal diversiteit zou voor wetenschappers de orde van dag zijn geweest. Couturat was er echter van overtuigd dat de invoer van één nationale taal als communicatiestandard geen oplossing bood. Nationale talen zijn namelijk te gecompliceerd, inefficiënt en nog erger: politiek geladen. Couturat beweerde ook dat het Latijn geen soelaas kon bieden omdat zij te complex en achterhaald is. De enige oplossing was dus de constructie van een nieuwe taal uit nationale talen.

Rond 1904/5 lijkt hij dan ook overtuigd dat Esperanto - een artificiële taal die in 1887 door de Poolse arts Ludovic Zamenhof was geconstrueerd - de beste oplossing was. In paragraaf 2.3 blijkt dat zijn voorkeur voor Esperanto slechts van korte duur was. In 1906 ging Couturat namelijk over tot de constructie van zijn eigen internationale taal die hij "Ido" noemde. Letterlijk vertaald betekent "Ido" nazaat. Met deze naam duidde hij de familiare verwantschap tussen Ido en Esperanto aan. Om de efficiëntie en neutraliteit van Ido te garanderen paste hij een wetenschappelijke methode toe tijdens haar creatie. Deze bestond uit het hanteren van twee logische principes: het univocity principe en het reversebility principe. Couturat beweerde ook dat hij de wortels van bestaande talen zo uitkoos zodat een maximum aantal Europeanen de taal zonder problemen kon begrijpen. Het eindresultaat zou een taal zijn geweest die dankzij haar logische structuur niet alleen perfect gesneden was voor de transfer van wetenschappelijke kennis. Het was vooral ook een neutrale taal die geen enkele gebruiker bevoorrechte of benadeelde.

Paragraaf 2.4 laat zien dat Couturat's karakterisering van de internationale gemeenschap als een nieuwe toren van Babel sterk overdreven was. Er worden verschillende ontwikkelingen beschreven, waaronder de verveelvoudiging van nationale talen gedurende de tweede helft van de negentiende eeuw) die aantonen dat Couturat's analyse niet helemaal onterecht was. Vervolgens wordt echter beargumenteerd dat alhoewel er in verschillende publicaties inderdaad over een taalprobleem werd geschreven, verreweg de meeste wetenschappers de situatie accepteerde zoals deze was. Couturat's campagnes voor de invoering van Ido leverden dan ook vrijwel geen steun op. Toch bleef hij tot aan zijn dood onverminderd strijdbaar voor Ido, waaruit valt op te maken dat Couturat naast zijn nobele oorlog tegen een imaginair probleem zo zijn eigen agenda had.

Paragraaf 2.5 beargumenteert dat Couturat's creatie en promotie van Ido onder andere werd gedreven door de strijd om een nieuwe vorm van objectiviteit, genaamd 
structurele objectiviteit, op de kaart te zetten. Dit argument bouwt voort op Lorraine Daston's en Peter Galison's boek Objectivity (2007). Daarin laten zij zien dat logici, filosofen en mathematici rond de eeuwwisseling een oudere vorm van objectiviteit (mechanische objectiviteit) bekritiseerden en daar structurele objectiviteit tegenover plaatsten. Couturat's toepassing van logica om een universele taal te creëren was een typisch voorbeeld van de trend om objectiviteit te genereren met structuren van logische verbindingen die wetenschap over de gehele wereld communiceerbaar moesten maken. Voorts wordt beargumenteerd dat Couturat's notie van logica sterk beïnvloed was door het werk van Wilhelm Gottfried Leibniz (1646-1716). Hij vond hierin niet alleen elementen om zijn eigen notie van logica vorm te geven (waaronder Leibniz's calaculus ratiocinator). Naast het idee om een internationale taal te generen (Leibniz ging hem voor door een characteristica universalis te creëren), trof hij bij Leibniz ook een voorbeeld aan van hoe de logica toegepast kon worden om een 'objectieve' taal te construeren.

Paragraaf 2.6 laat zien dat Couturat's interventie ook een antwoord was op de Dreyfus affaire. Aan de hand van een brieven aan zijn collega's Xavier Léon (1868-1935) en Bertrand Russell (1872-1970) en een gepubliceerde polemiek tussen Couturat en de Franse literaire criticus Ferdinand Brunetière (1849-1906) wordt aangetoond dat Couturat Ido zag als een poging om het militarisme en chauvinisme van de anti-dreyfusards teniet te doen. Couturat's wetenschappelijke collega's, waaronder zijn leermeester Henri Poincaré, waren eveneens actieve Dreyfusards. Zij mobiliseerden hun wetenschappelijke kennis dan ook ten faveure van Dreyfus. Ido was Couturat's manier om zijn kennis te mobiliseren. In zijn ogen vertegenwoordigde Ido namelijk de waarden van de Dreyfusards: tolerantie, internationale rechtvaardigheid, neutraliteit en rationalisme.

Paragraaf 2.7 toont aan dat Leibniz door Couturat ten onrechte als begin twintigsteeeuwse internationalist werd gepresenteerd. In zijn strijd om de relevantie van zijn door Leibniz geïnspireerde taal aan tonen, suggereerde Couturat dat Leibniz de characteristica universalis bedoelde als een middel om het nationalisme te overwinnen. Aan de hand van secundaire bronnen wordt echter aangetoond dat Leibniz een hele andere agenda had, namelijk de verspreiding van het christelijke geloof in China. Ook wordt aangetoond dat Leibniz zich uitsluitend op de culturele en religieuze uitwisseling tussen Europa en China richtte en hiermee bewust Afrika en het Midden-Oosten uitsloot.

Paragraaf 2.8 beargumenteert dat Couturat's definitie van de internationale gemeenschap in zekere zin niet veel breder was dan Leibniz's definitie. Couturat richtte zich uiteindelijk uitsluitend op de facilitering van wetenschappelijke communicatie tussen Europa en Amerika. Ook zijn definitie van Europa was beperkt: Ido's grammatica bestond vrijwel uitsluitend uit Romaanse taalelementen, waardoor het Oost-Europese gebruikers buitensloot. Ido was bovendien een typisch Frans project, want het was een uitdrukking van een Franse traditie om de eigen taal als een superieure want rationele taal te beschouwen (Couturat presenteerde Ido op precies dezelfde manier). Het kan dan ook gesteld worden dat Couturat's promotie van Ido een poging was om de status van Frankrijk als toonaangevende natie binnen Europa te rehabiliteren door haar een nieuwe wereldtaal 
te schenken. Tegen het einde van de negentiende eeuw was Frans immers de status als belangrijkste diplomatische en wetenschappelijke taal kwijtgeraakt.

\section{Hoofdstuk 3}

Paragraaf 3.1 beschrijft hoe Wilhelm Ostwald in 1901 door Couturat werd overgehaald tot de promotie van een wetenschappelijke internationale taal. Hij wordt namelijk in hetzelfde jaar lid van Couturat's "Delegatie voor de Adoptie van een Internationale Taal". Vanaf dat moment raakte Ostwald in toenemende mate overtuigd van de noodzaak voor de adoptie van een geconstrueerde taal om de werklast voor wetenschappers op internationale congressen te minimaliseren. Ook hij stelde dat de adoptie van een nationale taal of Latijn geen oplossing was. Tot 1906 presenteerde hij Esperanto als de beste oplossing. In datzelfde jaar verruilde hij echter Esperanto voor Ido. Een jaar later brak Ostwald met Couturat.

Inmiddels was er een heuse oorlog tussen de zogenaamde Esperantisten en de Idisten losgebarsten. Overweldigd door de zinloosheid van deze strijd besloot Ostwald om zijn campagne voor Ido op eigen houtje door te voeren. Paragraaf 3.2 toont dan ook aan dat Ostwald vanaf 1907 onverminderd actief steun voor Ido bleef zoeken. Ook wordt beschreven dat de invoering van Ido bij Ostwald vanaf 1911 deel uit maakte van een breder internationalistisch programma, genaamd "Die Brücke". Het doel van Die Brücke was om de internationale transfer en toegankelijkheid van wetenschappelijk kennis te bevorderen middels de invoer van een gestandaardiseerd printformaat, de creatie van een centraal kennisstation en natuurlijk de invoer van Ido als standaardtaal. Deze paragraaf bespreekt ook pogingen van Ostwald om Ido toe te passen, waaronder een mislukte poging om Ido samenvattingen door te voeren in zijn eigen tijdschrift Die Zeitschrift für Physkalische Chemie.

Paragraaf 3.3 beargumenteerd dat Ostwald's wetenschappelijke carrière zich kenmerkte door een grote internationale mobiliteit waardoor hij voortdurend in aanraking kwam met taaldiversiteit. Zijn succes als chemicus bracht hem van de Universiteit in Riga naar de universiteit van Leipzig, het centrum van de internationale wetenschap. Die Zeitschrift für Physikalische Chemie groeide uit tot een druk internationaal verkeerspunt waar wetenschappelijke kennis werd uitgewisseld. Zijn laboratorium in Leipzig trok bovendien studenten aan vanuit de hele wereld. Deze ontwikkelingen lijken op het eerste gezicht een motief te zijn voor Ostwald's engagement voor Ido in zijn poging om taaldiversiteit te overwinnen. Zoals reeds aangetoond veroorzaakte deze diversiteit echter geen serieuze communicatieproblemen. Dit suggereert dat Ostwald wellicht andere redenen had om zijn organisatieprogramma door te voeren.

Paragraaf 3.4 toont aan dat Ostwald's organisatieprogramma onder andere diende om de status van wetenschappers in Duitsland te bevorderen. Ostwald baseerde dit 
programma op een veralgemeende versie van de principes van de thermodynamica. Deze visie heet het energeticisme. Ostwald richtte zich echter niet alleen op het energieefficiënter maken van de internationale overdracht van wetenschappelijke kennis. Ook claimde hij het psychologische welzijn van het individu te bevorderen door deze in termen van energiehuishouding te presenteren. Sterker nog, Ostwald stelde dat de het energieefficiëntie maken van alle processen en fenomenen in de maatschappij zijn centrale missie was. Aan de hand van Russell McCormmach's werk wordt aangetoond dat dit alomvattende hervormingsplan een typische uitdrukking was van een begin twintigste-eeuw programma om wetenschappers als Kulturträgers, oftewel cultuurdragers, van de Duitse samenleving op de kaart te zetten.

Paragraaf 3.5 beschrijft hoe Ostwald gebruik maakte van August Comte's (17981857) positieve filosofie om zijn maatschappelijke hervormingsplan te legitimeren. Hij deed dit door het teleologische argument van de laatstgenoemde toe te passen in de vorm van een zogenaamde toenemende organisatiecapaciteit van de mens in vier stadia. Het vierde stadium - het einddoel - representeerde een volledig rationeel georganiseerde en geïntegreerde wereld. Ostwald stelde dat zijn eigen tijd echter nog steeds in het derde stadium vastzat omdat individuele en nationale belangen samenwerking nog steeds in de weg stonden. De internationale wetenschappelijke gemeenschap was echter een uitzondering. Zij vertoonde namelijk kenmerken van het vierde stadium. Daarom was het volgens Ostwald dan ook de bedoeling dat wetenschappers de wereld naar het vierde stadium zouden tillen. De adoptie van Ido was één van de manieren waarop deze missie uitgevoerd moest worden.

Paragraaf 3.6 laat echter zien dat alhoewel Ostwald stelde dat wetenschappers bij uitstek neutraal waren, hijzelf wel degelijk door nationale belangen werd gedreven. Ostwald's wetenschappelijke organisatie van de wereld sloot namelijk naadloos aan bij de imperiale ambities van kaiser Wilhelm II. Volgens Ostwald moest Duitsland namelijk het voortouw nemen in de organisatie van de wereld om haar dominante rol in Europa te garanderen. Dat zijn internationalistische programma niet alleen om uitbreiding van de machtvan Duitsland macht draaide, maar zelfs imperiale trekken vertoonde, blijkt uit Ostwald's conceptie van de internationale arena als "het nieuwe Afrika, een continent dat klaarligt om gekoloniseerd te worden". Kortom, het was Ostwald's ambitie om Duitsland uit te laten groeien tot een centraal verkeerspunt waar kennis uit de hele wereld verwerkt en als het ware gerooid werd ter bevordering van Duitsland.

Paragraaf 3.7 beargumenteert dat Oswald zijn internationale organisatieprogramma tijdens de Eerste Wereldoorlog voortzette in tegenstelling tot wat in de huidige literatuur wordt beweerd. Ostwald verruilde Ido immers voor een nieuwe internationale taal in de vorm een versimpeld Duits, genaamd Weltdeutsch. Ook nu voorzag Ostwald haar toepassing als een voorwaarde voor de totstandkoming van een machtiger Duitsland. Alleen articuleerde hij deze keer een explicietere versie van zijn ideeën over een toekomstige wereld waarin een machtiger Duitsland een centrale rol speelde. Het einddoel 
van zijn organisatie van de wereld was zelfs niets minder dan de realisatie van een gigantisch Duits rijk.

\section{Hoofdstuk 4}

Aangezien Frederick Cottrell's engagement voor een internationale taal na de Eerste Wereldoorlog begint, biedt paragraaf 4.1 ter inleiding een overzicht van de internationale taalpolitiek in die periode. Daarom wordt de status van verschillende internationale taalprojecten besproken, waaronder Louis de Beaufront's (1855-1935) hopeloze pogingen om tijdens en na de oorlog steun voor Ido te krijgen; de revitalisatie van de Esperantobeweging als Esperanto in 1921 bij de "League of Nations" voorgelegd wordt; en de korte aandacht voor een Basic English, een door C.K. Ogden (1889-1957) en Ira Richards (1878-1979) geïnitieerde internationale taalproject. Vervolgens bespreekt deze paragraaf Cottrell's pogingen om aandacht te generen voor de noodzaak van een wetenschappelijke internationale taal. Zijn missie begon in 1919 als voorzitter van de "Commissie voor een Internationale Hulptaal" van de "Internationale Onderzoeksraad". Cottrell steunde in tegenstelling tot Couturat en Ostwald geen specifiek taalproject. Zijn doel was namelijk de oprichting van een neutraal en objectief platform waarbij het internationale taal vraagstuk op wetenschappelijke manier onderzocht diende te worden. Verder benadrukte hij dat taal als een technologisch middel gezien moest worden. Juist daarom was onderzoek naar het internationale taalvraagstuk bij uitstek een taak voor wetenschappers. Ook stelde hij dat een internationale taal nodig was om nationalistische en egoïstische motieven binnen de wetenschap teniet te doen.

Paragraaf 4.2 traceert de oorsprong van Cottrell's interesse in het internationale taalvraagstuk in de Amerikaanse Esperantogemeenschap. Daar kwam Cottrell immers tot de conclusie dat het vraagstuk een wetenschappelijke benadering behoefde. Ook wordt aangetoond dat hij tevergeefs financiële en institutionele steun zocht van de "Amerikaanse Associatie voor de Bevordering van Wetenschap" en het Smithsonian Instituut in een eerste poging om een wetenschappelijk platform op te zetten.

Het eerste deel van paragraaf 4.3 zet Cottrell's argumenten voor de noodzaak van een internationale taal uiteen. Het wordt duidelijk dat hij van mening was dat de invoering van een standaardtaal ter bevordering van internationale communicatie in een door technologische ontwikkelingen steeds kleiner wordende wereld een logische stap was. Het tweede deel van deze paragraaf toont aan dat Cottrell met deze argumenten het technooptimisme verwoorde waaraan hij onder andere in 1915 op de Wereldtentoonstelling in San Francisco werd blootgesteld. Deze wereldtentoonstelling was één grote lofzang op de moderne technologie en de macht van de ingenieur over de natuur en de rol van technologie als oorzaak voor de ogenschijnlijk steeds kleiner wordende afstand tussen 
naties. Dit techno-optimisme was echter zo wijdverbreid dat het nauwelijks een verklaring biedt voor Cottrell's engagement voor het zogenaamde wetenschappelijke taalprobleem.

Paragraaf 4.4 introduceert het eerste specifieke component van Cottrell's ideologische programma: zijn conceptie van wetenschap als een sociaal experiment. Deze conceptie kwam voort uit het progressivisme, een politieke stroming die in Amerika tussen 1890 en 1920 het actiefst was. Eén van de kenmerken van een progressieve agenda was de toepassing van wetenschappelijke adviescommissies om maatschappelijke problemen op "experimentele" wijze te verhelpen. Het doel was in veel gevallen om toenemende corruptie en individuele excessen van het kapitalisme tegen te gaan. Dat Cottrell een progressieve agenda had wordt duidelijk gemaakt aan de hand van zijn in 1912 opgezette "Research Corporation". Het doel van deze experimentele en revolutionaire corporatie was het tegengaan van de verkaveling van wetenschap onder invloed van het kapitalisme. Cottrell had een dergelijke benadering en functie van het internationale taalprobleem voor ogen. Maar de oorzaak van de verkaveling van de internationale gemeenschap was deze keer het nationalisme in plaats van het kapitalisme.

Paragraaf 4.5 maakt duidelijk dat Cottrell's engagement voor het internationale taalvraagstuk een poging was om de status van ingenieurs in Amerika te bevorderen. Deze strijd werd vanaf ongeveer 1900 in Amerika door een groep ingenieurs gevoerd. Cottrell nam deel aan deze strijd. Hij claimde namelijk dat ingenieurs onder het juk van de managers vandaan moesten kruipen omdat zij beter dan andere groepen in de maatschappij in staat waren om het welzijn van de gehele mensheid te garanderen. De oplossing van het internationale taalvraagstuk op een technologische manier was Cottrell's poging om aan te tonen dat dit het geval was.

Paragraaf 4.6 toont aan dat Cottrell's promotie van het internationale taalvraagstuk als voorzitter van de "Commissie voor een Internationale Hulptaal" van de Internationale Onderzoeksraad ook door een nationale agenda werd gedreven. Cottrell's zelfbeeld als de architect van een betere samenleving ging namelijk hand in hand met het bevorderen van Amerikaanse belangen op een internationaal niveau. De Internationale Onderzoeksraad werd dan ook sterk gedreven door Amerikaanse belangen. Bovendien volgde deze raad het beleid van de eveneens Amerikaans georiënteerde "League of Nations". Dit resulteerde in de buitensluiting van wetenschappers van de Centrale Mogendheden. Daarmee was de internationale gemeenschap die Cottrell van een internationale taal wilde voorzien een stuk kleiner dan de mensheid, aangezien deze vanuit zijn positie vrijwel uitsluitend uit Amerikanen en West-Europeanen bestond.

In 1924 werd Cottrell's "Commissie voor een Internationale Hulptaal" opgedoekt. Een jaar later stichtte hij samen met de welvarende filantroop Alice Morris Vanderbilt (1874-1950) de "Associatie voor een Internationale Hulptaal". Het doel van deze associatie was wederom om wetenschappelijk onderzoek naar het internationale taalvraagstuk te organiseren. Paragraaf 4.7 beargumenteert dat deze associatie een product was van zowel Cottrell's campagne om de ingenieur op de kaart te zetten als Alice Morris Vanderbilt's campagne om haar beruchte familienaam in een positief daglicht te zetten. Het 
engagement van de laatst genoemde was namelijk een typisch voorbeeld van een vroeg twintigste-eeuwse trend onder rijke kapitalisten om hun slechte reputatie als scrupuleuze uitbuiters schoon te poetsen middels filantropie.

Paragraaf 4.8 toont aan dat de Associatie voor een Internationale Hulptaal in de jaren dertig de creatie van Interlingua, een nieuwe wetenschappelijk geconstrueerde taal, faciliteerde. Cottrell is tegen die tijd echter niet meer betrokken bij activiteiten van de associatie. Bovendien zijn de makers van deze taal linguïsten (waaronder Edward Collinson en Alexander Gode) in plaats van wetenschappers. Linguïsten zagen in Cottrell's Associatie namelijk een kans om linguïstiek een wetenschappelijke status te geven. In de jaren twintig en dertig werd linguïstiek immers nauwelijks als een wetenschappelijke discipline beschouwd. Hoe dan ook, met de betrokkenheid van linguïsten kwam de promotie van een wetenschappelijke internationale taal door wetenschappers tot een einde. Interlingua was echter wel bedoelt om wetenschappelijk communicatie te faciliteren.

\section{Hoofdstuk 5}

Paragraaf 5.1 werkt de notie van wetenschappelijk internationalisme als een lappendeken van individuele programma's verder uit. Allereerst beargumenteert deze paragraaf dat de campagnes van Couturat, Ostwald en Cottrell vanaf een afstand gezien kunnen worden als een min of meer coherente beweging van wetenschappelijk linguïstisch internationalisme. Hierbij worden de volgende vijf gedeelde voorwaarden en ingrediënten van deze beweging geïdentificeerd: 1) de negentiende-eeuwse opkomst van internationalisme als politieke ideologie; 2) het idee dat vooruitgang van wetenschap en technologie bijdragen aan een steeds kleiner wordende wereld; 3) de toename van nationale talen binnen de wetenschappelijke gemeenschap; 4) de opkomst en populariteit van internationale taalprojecten en dan met name artificiële taalprojecten zoals Esperanto; 5) het zelfbeeld van wetenschappers als architecten van een rationale en harmonieuze wereldorde waarin nationalisme en chauvinisme tot het verleden behoren.

Het vervolg van deze paragraaf benadrukt echter dat onder deze gedeelde ingrediënten grote ideologische diversiteit schuilde die op vier niveaus tot uitdrukking kwam: 1) de drie protagonisten hadden ieder een andere conceptie van wat hun internationale taal wetenschappelijk maakte (Couturat: logica, Ostwald: thermodynamica, Cottrell: technologie): 2) ideologische diversiteit kwam tot uitdrukking in verschillende intellectuele rolmodellen die protagonisten opvoerden en toepasten binnen hun programma's (Couturat: Leibniz, Ostwald: Comte, Cottrell: Thorstein Veblen); 3) de protagonisten werden ieder op hun beurt door een andere status bevorderingscampagne gedreven (Couturat: legitimatie van structurele objectiviteit en daarmee van logici, filosofen en wiskundigen, Ostwald: bevordering van wetenschappers tot cultuurdragers van Duitsland, Cottrell: status bevordering van de ingenieur als architect van een betere 
maatschappij); 4) het linguïstische internationalisme was een uitdrukking van verschillende nationale perspectieven en de daarmee gepaard gaande wereldconcepties waarin de thuisnatie een centrale rol speelde.

Paragraaf 5.2 benadrukt niet alleen het divergente, maar vooral ook het enge karakter van het begin twintigste-eeuwse wetenschappelijk linguïstisch internationalisme in termen van de concepties van de internationale arena die de protagonisten presenteerden tijdens hun campagnes. Couturat's notie van de internationale gemeenschap beperkte zich tot Amerika en Europa en zijn definitie van Europa beperkte zich tot West-Europa. Ostwald definieerde de internationale arena als "een continent dat klaarlag om gekoloniseerd te worden" en hij voorzag de expansie van Duitsland richting het zuidoosten. Cottrell's conceptie van de internationale arena kwam sterk overeen met Couturat's idee. Deze beperkte zich eveneens tot Amerika en West-Europa als gevolg van de buitensluiting van de Centrale Mogendheden. Voorts is het opvallend dat geen van de drie protagonisten over de facilitering van communicatie met en binnen Azië, het Midden-Oosten, Afrika en ZuidAmerika schreef (behalve Ostwald, maar hij deed dit als een uitdrukking van een imperialistische agenda). Het ontbreken van deze regio's in hun programma's toont aan dat de drie protagonisten een typische Belle époque conceptie van de internationale arena hadden. Tot slot deelden de protagonisten een enge conceptie van wat en hoe men op internationaal niveau diende te communiceren. Hun focus op de efficiëntie en rationaliteit van internationale communicatie liet namelijk weinig ruimte over voor bijvoorbeeld de uitwisseling van literatuur en poëzie.

Paragraaf 5.3 beargumenteert dat alhoewel uit het voorgaande blijkt dat wetenschappelijk internationalisme door individuele belangen en nauwe concepties werd gedreven, dit niet verklaart waarom het beeld van wetenschappers als voorbeeldige internationalisten die gedreven worden door een gedeeld ideologische programma keer op keer blijft opduiken. Voor een mogelijke verklaring dient men bij de constructivistische school van nationalisme studies aan te kloppen. Daar bestudeert men immers de eenheid en cohesie van nationale gemeenschappen als een opgelegde mythe die keer op keer word gearticuleerd om het idee van een gedeelde culturele identiteit in stand te houden. Interessant genoeg speelt de promotie van een standaardtaal in dit proces een centrale rol.

In de rest van deze paragraaf wordt aangetoond op welke manier taal tijdens de negentiende eeuw door nationalisten werd gebruikt om een gedeelde identiteit te creëren. Zij deden dit onder andere door taal als een uitdrukking van de zogenaamd unieke en superieure waarden van haar gebruikers te promoten. Franse nationalisten benadrukten bijvoorbeeld het moderne en rationele karakter van het Frans om haar gebruikers eraan te herinneren dat Frankrijk een toonaangevende natie was die de verlichting had voortgebracht. In reactie hierop kweekten Duitse nationalisten het beeld dat juist de Duitsers deel uitmaakten van een superieure nationale cultuur. Dit deden zij door het Duits als een oeroude taal te presenteren die haar gebruikers in staat stelde om in contact te blijven met de tijdloze essentie van hun natie. Nationalisten gebruikten taal dus ook om een gedeelde nationale identiteit te verankeren in een ver en geïdealiseerd verleden. Op 
die manier cultiveerden Franse nationalisten het beeld van zichzelf als erfgenamen van het Romeinse rijk. Zij presenteerden Frans namelijk als een afgeleide van het Latijn.

Paragraaf 5.4 analyseert hoe de drie protagonisten taal gebruikte om een gedeelde identiteit op internationaal niveau te kweken. Evenals de nationalisten presenteerden zij hun taal immers als een uitdrukking van de deugden en waarden (efficiëntie, rationaliteit, neutraliteit) die haar beoogde gebruikers met elkaar moest verbinden. Ook gebruikten zij taal om de wetenschappelijke gemeenschap in een geïdealiseerd verleden te verankeren. Door hun taal als een moderne versie van het Latijn te presenteren herinnerden zij haar gebruikers eraan dat ze in de traditie van de République des Lettres stonden. Alhoewel de drie protagonisten een taal presenteerde die op het eerste gezicht ver van nationale talen afstond dankzij haar artificiële en rationele karakter, kenden zij deze taal wel degelijk mystieke kwaliteiten toe. In plaats van het idee dat taal toegang verschaft tot een mystieke en oeroude essentie, verleende de wetenschappelijke taal haar gebruikers toegang tot het rijk van objectieve, tijdloze kennis.

Gebruikmakend van Benedict Anderson's conceptie van naties als Imagined Communities, oftewel ingebeelde gemeenschappen, suggereert paragraaf 5.5 dat internationalisme net als nationalisme in stand gehouden wordt door een ingebeeld narratief van kameraadschap tussen haar voorstanders. Het was de functie van de wetenschappelijke taal om haar gebruikers aan hun onderlinge kameraadschap en hun gedeelde illustere verleden te herinneren. Zoals Anderson duidelijk maakt: “(...) niets brengt ons affectief meer in contact met de overledenen dan taal". Ondanks het feit dat de begin twintigste-eeuwse pogingen om een wetenschappelijke internationale taal in te voeren mislukt zijn, waren deze op z'n minst een effectieve manier om ons aan een tijd te herinneren toen wetenschappers deel uitmaakten van een harmonieuze gemeenschap die hen zogenaamd boven persoonlijke en nationale rivaliteiten uittilde. 


\section{Curriculum Vitae}

Fabian de Kloe (1982) obtained his master degree in Art, Literature and Society at the Faculty of Arts and Social Sciences, Maastricht University (FASoS). He graduated in 2006 with a master thesis in the history of science. Since then he has taught a wide range of courses at the same faculty. In 2008 FASoS awarded him with a 4-year PhD project grant. Fabian was trained within the local Graduate School as well as the Netherlands Graduate Research School of Science, Technology and Modern History (WTMC). In 2011 he was awarded a visiting fellowship by the Harvard History of Science Department. Fabian currently works as an independent historian and text writer. 
This book zooms in on a remarkable early-twentieth-century case of scientific internationalism: attempts by scientists to create and adopt a scientifically constructed international language. Its central proponents were French mathematician and logician Louis Couturat (1868-1914), German chemist and Nobel Laureate Wilhelm Ostwald (1853-1932) and American chemist and inventor Frederick G. Cottrell (1877-1948). Inspired by contemporary international language projects - most notably Esperanto - each pursued the application of science in the creation and adoption of a new language that guaranteed a smooth, highly efficient transfer of knowledge across national boundaries. In doing so, it was supposed to give rise to a more tightly integrated and harmonious scientific community.

Couturat's, Ostwald's, and Cottrell's program appeared to confirm the image of scientists as exemplary internationalists. But this book shows that they were more driven by the push of personal and national agendas than by the pull of international demand. As such, their campaigns served the interests of distinct professional, regional and especially national communities. In fact, their new language facilitated a world order that mapped neatly onto regions targeted in the hegemonic and imperial agendas of their respective home nations. Moreover, the act of promoting a scientific international language mirrored nationalist agendas on another level. Its three proponents copied from nationalists the use of language to construct a shared sense of identity. But instead of mobilizing language to construct community on a national level, they did so on an international level. 